\title{
On the inflammatory and infectious aspects of atherosclerosis: a serological, molecular biological \& clinical treatise
}

Citation for published version (APA):

Vainas, T. (2006). On the inflammatory and infectious aspects of atherosclerosis: a serological, molecular biological \& clinical treatise. [Doctoral Thesis, Maastricht University]. Datawyse / Universitaire Pers Maastricht. https://doi.org/10.26481/dis.20050217tv

Document status and date:

Published: 01/01/2006

DOI:

10.26481/dis.20050217tv

Document Version:

Publisher's PDF, also known as Version of record

Please check the document version of this publication:

- A submitted manuscript is the version of the article upon submission and before peer-review. There can be important differences between the submitted version and the official published version of record.

People interested in the research are advised to contact the author for the final version of the publication, or visit the DOI to the publisher's website.

- The final author version and the galley proof are versions of the publication after peer review.

- The final published version features the final layout of the paper including the volume, issue and page numbers.

Link to publication

\footnotetext{
General rights rights.

- You may freely distribute the URL identifying the publication in the public portal. please follow below link for the End User Agreement:

www.umlib.nl/taverne-license

Take down policy

If you believe that this document breaches copyright please contact us at:

repository@maastrichtuniversity.nl

providing details and we will investigate your claim.
}

Copyright and moral rights for the publications made accessible in the public portal are retained by the authors and/or other copyright owners and it is a condition of accessing publications that users recognise and abide by the legal requirements associated with these

- Users may download and print one copy of any publication from the public portal for the purpose of private study or research.

- You may not further distribute the material or use it for any profit-making activity or commercial gain

If the publication is distributed under the terms of Article $25 \mathrm{fa}$ of the Dutch Copyright Act, indicated by the "Taverne" license above, 
On the inflammatory and infectious aspects of atherosclerosis:

a serological, molecular biological \& clinical treatise 
Copyright $\odot 2006$ Tryfon Vainas, Maastricht ISBN 9052785120

Layout: Tiny Wouters

Production: Datawyse / Universitaire Pers Maastricht

Cover illustration: Trojan Horse, drawing by Christina Nikou ( 7 years old) and adapted by Mrs. Nicole Hardy. The original is part of the author"s private collection.

Greek soldiers finally entered and conquered the city of Troy, after a siege of 10 years, hidden in the belly of a wooden horse. Similarly, many proatherogenic factors, such as Chlamydia pneumoniae may reach the vascular wall within the macrophages. 


\title{
On the inflammatory and infectious aspects of atherosclerosis:
}

a serological, molecular biological \& clinical treatise

\author{
PROEFSCHRIFT
}

ter verkrijging van de graad van doctor aan de Universiteit Maastricht, op gezag van de Rector Magnificus,

Prof. mr. G.P.M.F. Mols, volgens het besluit van het College van Decanen, in het openbaar te verdedigen op vrijdag 17 februari 2005 om 16.00 uur

door

Tryfon Vainas

geboren op 26 october 1969

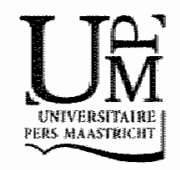


Promolor:

Prof. dr. P.J.E.H.M. Kitslaar

Prof. dr. C.A. Bruggeman

Copromotor:

Dr. F.R.M. Stassen

Dr. H.A.J.M. Kurvers

Beoordelingscommissie:

Prof. dr. M.J.A.P. Daemen (voorzitter)

Dr. J.S. Lindholt (Sygehus Viborg. Denmark)

Prof. dr. F.L. Mol (Universiteit Utrecht)

Prof. dr. M.H. Prins

Prof. dr. J. Waltenberger

The studies described in this thesis were supported by a grant of the Netherlands Heart Foundation (NHF-98.149)

Financial support by the Netherlands Heart Foundation for the publication of this thesis is gratefully acknowledged. 
In memory of Marcel van den Berg.

The soul of a man is immortal and imperishable.

Plato 


\section{Contents}

Section 1 Introduction \& Aims of thesis 9

Chapter 1 General Introduction \& Aims of the thesis 11

1.1 Definition 13

1.2 Atherosclerotic lesion types and development 13

1.3 Clinical manifestations of atherosclerosis and their treatment 16 in historical perspective

$1.3 a$ Coronary artery disease $\quad 16$

$\begin{array}{ll}1.3 \mathrm{~b} \text { Cerebrovascular disease } & 17\end{array}$

$\begin{array}{ll}1.3 \mathrm{c} & \text { Peripheral arterial disease } \\ 18\end{array}$

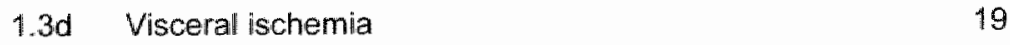

$\begin{array}{lll}1.3 \mathrm{e} & \text { Abdominal aortic aneurysms } & 20\end{array}$

1.4 Epidemiology of atherosclerotic disease 21

1.5 Risk factors for atherosclerosis 23

1.6 Pathogenesis of atherosclerosis - the inflammatory paradigm 24

1.7 Atherosclerosis and C-reactive protein 25

$\begin{array}{lll}1.8 & \text { Atherosclerosis and infections } & 27\end{array}$

1.8a Chlamydia pneumoniae biology \& epidemiology 27

1.8b Chlamydia pneumoniae and atherosclerosis 29

1.8b.I Sero-epidemiological evidence $\quad 29$

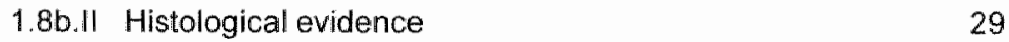

1.8b.III Experimental evidence $\quad 30$

$1.8 \mathrm{~b}$. IV Antibiotic trials

$1.8 \mathrm{~b} . \mathrm{V}$ Mechanism of disease $\quad 32$

1.9 Aims of the study and outline of the thesis 33

Section 2 Inflammation \& atherosclerosis 51

Chapter 2 CRP in peripheral arterial disease: relation to severity of the disease 53 and to future cardiovascular events

Chapter 3 Serum C-reactive protein level is assoclated with abdominal aortic aneurysm size and the protein may be produced by aneurysmal tissue

Section 3 infection \& atherosclerosis

Chapter 4 Chlamydia pneumoniae serology: comparing a commercial enzyme immunoassay and microimmunofluorescence test in patients with cardiovascular disease 
Chapter 5 Chlamydia pneumoniae in atherosclerotic disease: evaluating the assaciation between serum antibodies and presence of antigens or DNA in vascular tissue

Chapter 6 Chlamydia pneumoniae serology is associated with thrombosisrelated but not with plaque-related micromembolization during carotid endarterectomy

Section 4 Genetic determinants of atherosclerosis susceptibility

Chapter 7 Synergistic effect of Toll-Like receptor 4 and CD-14

polymorphisms on the total atherosclerosis burden in patients with peripheral arterial disease

Section 5 Clinical intervention trial

Chapter 8 Secondary prevention of atherosclerosis through Chlamydia pneumoniae eradication (SPACE trial): a randomised clinical trial in patients with peripheral arterial disease

Section 6 General discussion and Summary

Summary

Samenvatting

Пврілп廿п

Acknowledgments

List of publications 



\section{Section 1}

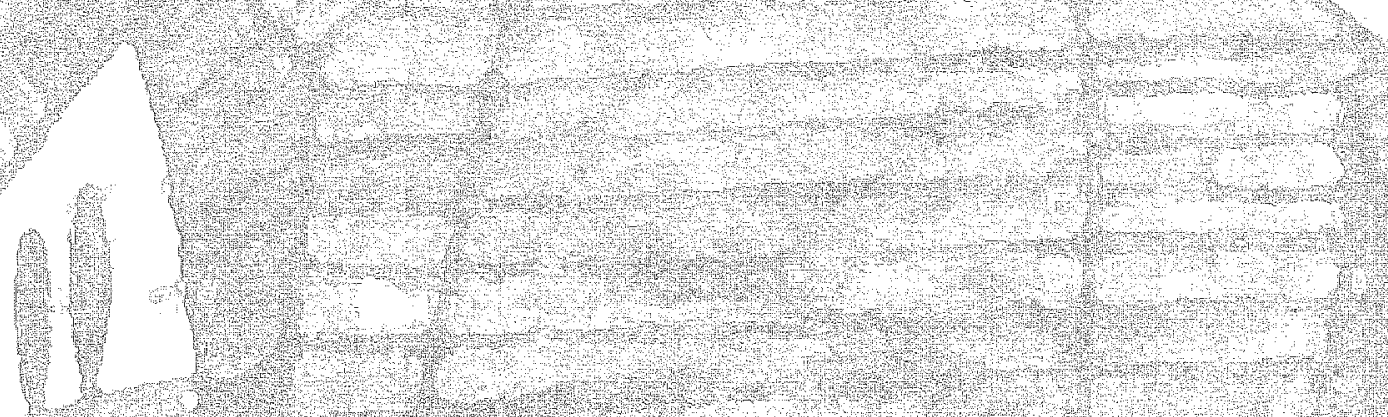

\section{Introduction \& Aims of thesis}



10 


\section{Chapter 1}

General introduction \& Aims of the thesis 
12 Chapter 1 


\subsection{Definition}

The term atherosclerosis is derived from the Hellenic a日npl (athere = gruel)

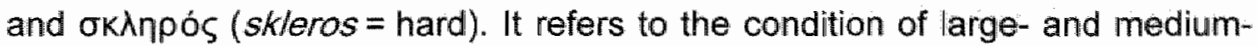
sized arteries associated with thickening and hardening of the vessel wall due to accumulation of lipids and fibrous elements. This leads to narrowing of the vascular lumen, hence obstructing blood flow to the organs supplied by the affected artery. Acknowledging the consistent association of fatty degeneration and arterial stiffening, Dr. Felix Marchand of Leipzig introduced the term in $1904 .^{1}$

Atherosclerotic changes are a common feature of the vasculature of even asymptomatic individuals. Autopsies in infants, children and adolescents have shown that the first atherosclerotic lesions appear very early in life. Advanced lesions are a consistent finding in middle-aged men and women. Patients with atherosclerotic cardiovascular disease exhibit complicated atherosclerotic lesions, often at multiple sites.

\subsection{Atherosclerotic lesion types and development}

By convention, atherosclerotic lesion types are designated with the numerals I to VIII, signifying the order in which the distinct lesion types develop. ${ }^{2}$ The earliest manifestation of atherosclerosis, the type I lesion consists of small isolated groups of macrophages that may contain lipid droplets (the macrophage foam cell) and extra-cellular accumulations of lipoproteins in the intima that do not disrupt the intercellular matrix structure. Type I lesions can be observed in atherosclerosis prone locations of the vascular tree of foetusses ${ }^{3}$ and young infants ${ }^{4.5}$ as well as in moderately susceptible locations of arteries of older children and adults. ${ }^{4,5}$

During childhood and puberty, type II lesions develop at atherosclerosis prone sites of the vascular tree. They consist of macrophage foam cells arranged in layers and indigenous smooth muscle cells. Occasionally, T-lymphocytes and mast cells can be found in these lesions. In addition to macrophages, intimal smooth muscle cells may contain lipid. Furthermore, minute quantities of lipid droplets and small lipoprotein particles can be found in the extra-cellular space. ${ }^{6}$ Some, but not all type II lesions are visible to the unaided eye as fatty streaks, i.e., yellow coloured streaks, patches, or spots on the intimal surface of arteries. Of all the type II lesions present in a person, only a small group will develop into type III and subsequently into the more advanced lesions. Mainly, those type II lesions developing at the predictable, atherosclerosis-prone sites will further proceed to more advanced lesions. Local hemodynamic conditions seem to play an important role herein. ${ }^{7}$ Type I and II lesions are frequently 
referred to as early lesions, implying that they are found early in life and/or that they precede the development of advanced lesions.

Type III lesions form the morphological and chemical bridge between type II and type $N$ lesions (i.e., atheromas) and are therefore also known as transitional lesions or preatheroma. ${ }^{8}$ Type $\| I$ lesions have the same cellular constituents as type II lesions but are characterized by extra-cellular lipid droplets that coalesce to form lipid pools among the layers of intimal smooth muscle cells, without however forming a single massive lipid core, i.e., a confluent accumulation of extra-cellular lipid. Compared to type II lesions, preatheromas contain more free cholesterol, fatty acid, sphingomyelin, Iysolecithin and triglycerides.

Atherosclerotic lesions characterized by cellular and molecular changes resulting in disruption of intimal structure and luminal and vessel-wall architecture are consildered advanced lesions. Histologically, advanced lesions are classified as types IV, V, VI, VII, and VIII. During early adolescence, type IV advanced atherosclerotic lesions that potentially may have clinical sequelae develop at susceptible arterial sites. The characteristic feature of the type IV lesion or atheroma is the lipid core, i.e., a massive accumulation of extracellular lipid at the abluminal part of the intima. At the luminal site, the core is covered by a layer of tissue with the usual thickness of the intima at that site. Type IV lesions do not necessarily narrow the vessel lumen but may become symptomatic when the tissue overlying the lipid core is disrupted leading to acute thrombotic obstruction. Type $\mathrm{V}$, fibroatheromatous lesions develop from atheroma through deposition of fibrous connective tissue either by organization of a luminal thrombus, extension of adjacent fibroatheroma, or resorption of the lipid core. Extensive fibrous degeneration may lead to the development of a lipid core free lesion designated type VIII (fibrotic) lesion. In contrast, excessive deposition of calcium crystals in the lipid core may lead to the development of type VII (calcified) lesions when more than $50 \%$ of the cross sectional area of the lesion consists of mineral. When (fibro)atheromatous (type IV or V) lesions develop surface disruptions, haematomas, thrombi or a combination of the above, they are designated type $\mathrm{V}$ l or unstable plaques. In case the above episodes are not fatal, fissures, haematomas and thrombi are colonized by intimal smooth muscle cells that will produce collagen, resulting in development of a lesion with type $V$ morphology and with a greater luminal obstruction than before the complicating event.

It has generally been accepted that clinically overt atherosclerotic lesions develop from early, type $\mid$ and $I I$ lesions. ${ }^{5}$ An increasing amount of experimental ${ }^{10-12}$ and clinical ${ }^{13-16}$ evidence suggests that atherosclerotic plaques may regress or even disappear. It has been suggested that plaque senescence with plaque volume reduction combined with continuous outward remodelling, may result in aneurysm formation. Thus, formation of aneurysm 
may represent the latest stage of atherosclerotic degeneration. ${ }^{17}$ Figure 1.1 shows the atherosclerotic lesion types and their suggested pathways of progression and regression.

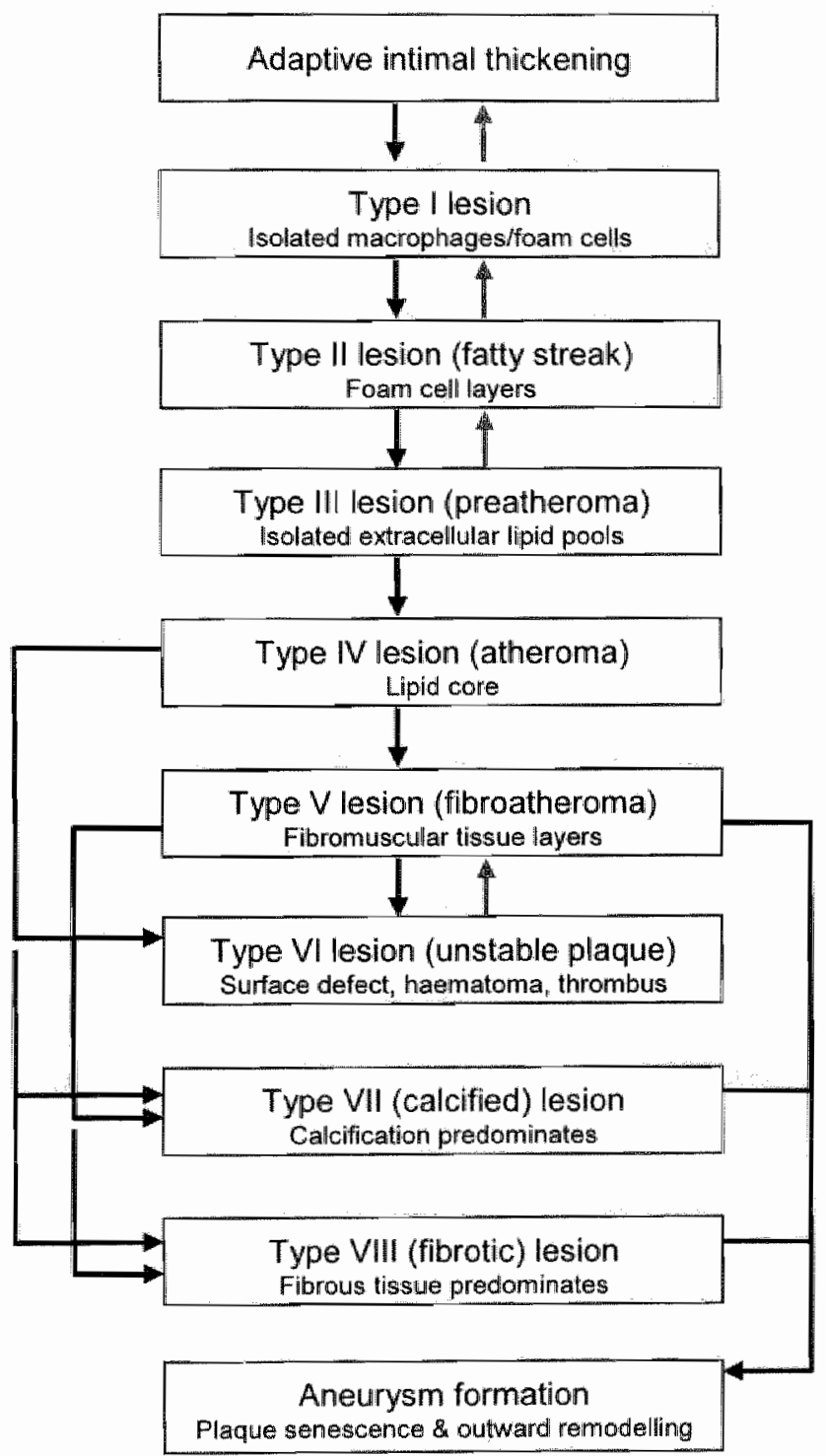

Figure 1.1 Schematic representation of the sequence in the development of atherosclerotic lesions. A black arrow signifies a pathway of progressions and a grey arrow represents a regression pathway, Adlapted from Stary ot al. ${ }^{2}$ 


\subsection{Clinical manifestations of atherosclerosis and their treatment in historical perspective}

Obstructed blood flow resulting from luminal stenosis or occlusion is the common denominator of the clinical conditions caused by atherosclerosis. Luminal stenosis or complete occlusion at the site of an atherosclerotic plaque may result from plaque growth or thrombosis triggered by plaque rupture or ulceration. Alternatively, atherothromboembolism may result in arterial occlusions remote of the culprit atherosclerotic lesion when plaque matter or thrombus dislodges from the unstable plaque and occludes a smaller artery further downstream. This is the case in strokes that are related to carotid artery disease. Since it might affect any artery, atherosclerosis may virtually afflict all organs. However, mostly, the heart, the brain, the (lower) limbs, the kidneys or the intestines are affected. Regardless the affected organ, ischemic pain, tissue necrosis and/or loss of organ function are the clinical manifestations of decreased blood flow.

\section{3a Coronary artary disease}

Atherosclerotic lesions in coronary arteries give rise to ischemic heart disease. The clinical presentation varies from chest pain of increasing severity (i.e., exertional chest pain (angina pectoris) or chest pain at rest (unstable angina)) to myocardial infarction. The ischemic damage to the heart may cause rhythm abnormalities, valvular dysfunction, cardiac failure, and may ultimately result in the death of the patient.

The first description of angina pectoris was given by William Heberdeen when he addressed the Royal College of Physicians in $1768 .{ }^{18}$ Shortly hereafter, in 1799 , it had been suggested that "...the principal cause of angina pectoris may be looked for in the disordered coronary arteries. ${ }^{19}$ In 1928, Keefer and Resnik confirmed that myocardial anoxemia was the underlying cause of angina, and that it could be caused by such diverse conditions as coronary artery disease, vasospasm, and decreased oxygen saturation of the blood. Although James B. Herrick had already in 1912 speculated that '...hope for the damaged myocardium lies in the direction of securing a supply of blood ... so as to restore as far as possible its functional integrity, ${ }^{20}$ medical and surgical reperfusion of obstructed coronary artery in order to relief ischemic symptoms became only available in the 1960 "s. Despite the fact that the first report of successful thrombolytic therapy was published in $1958,{ }^{21}$ it took another quarter of a century before the life-saving potential of fibrinolytic therapy in acute myocardial infarction was unequivocally demonstrated. ${ }^{22}$ The first direct surgical myocardial revascularization was performed in 1962 when Effler and his team alleviated a severe obstruction of the left coronary artery using the technique of endarterectomy combined with patch grafting. ${ }^{23}$ DeBakey and 
Garrett have probably performed the first successful coronary artery vein bypass graft in response to an intra-operative misadventure. ${ }^{24}$ The first elective coronary artery bypass graft using a venous conduit was performed by Rene Favaloro in $19677^{25}$ who subsequently developed the technique for use in multivessel coronary artery disease. ${ }^{26}$ In 1977 . Andreas Gruentzig performed the worlds first percutaneous transluminal angioplasty of an obstructed coronary artery, offering the medical community a minimally invasive technique for the desobstruction of coronary arteries. ${ }^{27}$ This technique has been taken a step further with the introduction of coronary stents to increase the patency of angioplastied arteries. ${ }^{28}$ Thanks to these technological advances and to the implementation of more effective primary and secondary preventive measurements, mortality from myocardial infarction alone has decreased more than $30 \%$ in the last 30 years.

\section{$1.3 b$ Cerebrovascular disease}

Atherothrombotic occlusion of the arteries supplying the brain may lead to temporary or permanent ischemic brain damage resulting in temporary (transient ischemic attack) or permanent (stroke) focal neurological deficit. Approximately $30 \%$ of cerebrovascular accidents result from atherothrombotic disease of the aortic arch or extracranial arteries. Another $20-25 \%$ of ischemic cerebral events result from embolism of cardiac origin. Lacunar strokes resulting from acclusion of intracranial small vessels account for $15-20 \%$ of cerebral infarctions. The remaining $30 \%$ of ischemic strokes are due to less common conditions, such as vasculitis and paradoxical embolism through a patent foramen ovale or are of unknown origin. ${ }^{29}$

The ancient Greeks were familiar with the concept of paralysis following injuries to the contralateral site of the brain, a phenomenon Hippocrates called apoplexy. Hippocrates furthermore gave the first account of a transient ischemic attack, but ischemia or haemorrhage as cause of apoplexy eluded him. In 1658 the Swiss physician Wepfer was the first to describe carotid thrombosis. In his Apoplexia he described the clinical pictures of completed stroke, progressing stroke and transient ischemic attack and noted that apoplexy may result from occlusion of the extra-cranial cerebral arteries. ${ }^{30}$ Subsequently Virchow ${ }^{30}$ and Penzoldt ${ }^{31}$ reported cases of carotid thrombosis associated with blindness and hemiplegia. Nevertheless, until fairly recently, the prevailing notion of the medical community was that strokes were caused by intracranial vascular disease. Sir William Osler attributed apoplectic stroke largely to cerebral haemorrhage or to thromboembolic occlusion of intracranial arteries. ${ }^{32}$ In 1914, Hunt emphasized the importance of occlusions of extracranial arteries in cerebrovascular disease ${ }^{33}$ and he was later joined by Fisher ${ }^{34}$ who stated: 'It is even conceivable that some day vascular surgery will find a way to bypass the occluded portion of the artery during the period of 
ominaus fleeting symptoms.' Indeed, in the same year DeBakey ${ }^{35}$ performed the first successful carotid endarterectomy followed a few months later by Eastcott and Rob. ${ }^{36}$ Following these landmark cases, carotid endarterectomy has proven to be a valuable prophylactic treatment option for patients with (potential) cerebrovascular disease due to (a)symptomatic extracranial carotid artery plaques. ${ }^{37,38}$ Another recent development, i.e., the introduction of thrombolytic therapy in acute ischemic cerebral events, has contributed significantly to the prevention of the devastating sequelae related to ischemic cerebrovascular disease. ${ }^{39}$

\section{$1.3 c$ Perioheral anterial disease}

Peripheral arterial disease refers to the clinical manifestations of stenosis or occlusion of arteries supplying the lower extremities. Atherosclerosis is nowadays the most frequent cause of peripheral arterial obstructive disease. Dependent on the degree of arterial stenosis and presence of collateral circulation, patients may be symptom-free or suffer from ischemic symptoms of increasing severity. Moderate obstructions in the presence of collateral circulation may give rise to exercise induced leg pain that subsides after resting (intermittent claudication). With increasing severity of arterial obstruction, ischemic pain may already be present at rest and/or tissue viabillity may be compromised leading to non-healing arterial ulcers.

The association between ischemic leg symptoms (claudication, arterial ulcers) and occlusions of supplying arteries had only been laid in the $19^{\text {th }}$ century. In fact, intermittent claudication due to arterial occlusion was first diagnosed by the French veterinary surgeon Jean-Francois Bouley in a horse drawing a carriage in 1831. The animal started to limp with the hind legs after standard exercise. At autopsy, a partially thrombosed aneurysm of the abdominal aorta with occlusions of both femoral arteries were seen and the femoral occlusions were correctly identified as the cause of symptoms. ${ }^{40}$ Jean-Martin Charcot, who was aware of Bouley"s work, first described intermittent claudication, in 1858, in a patient who developed claudication secondary to a thrombosed traumatic illac aneurysm. ${ }^{40}$ The combination of exercise induced leg pain, tension or weakness that disappears after a period of rest, due to arterial occlusions, has also been called Charcot's syndrome or angina cruris.

For the longest part of medical history, amputation of an ischemic gangrenous limb was the only therapeutic option available for severe peripheral arterial disease. Direct arterial reconstruction for atherothrombotic disease had to await the development of vascular suture techniques and the introduction of heparin. In 1947, Jao Cid Dos Santos of Lissabon performed the first successful endarterectomy of an obstructed iliac artery. ${ }^{41}$ This major breakthrough, was soon followed by another important milestone of vascular surgery when Jean Kunlin performed the first femoropopliteal bypass for atherosclerotic obstructive 
disease using the patients own greater saphenous vein. ${ }^{42}$ It should be mentioned however that the first successful vascular reconstruction using a saphenous vein graft in a patient with a traumatic lesion of the femoral artery and vein after sustaining a gunshot wound to the groin was performed by Murphy in Chicago in 1897.43 Aortic occlusions represented a surgical challenge not suitable for saphenous vein bypass grafting. The use of arterial homografts had been introduced in 1948 for the management of coarctation, ${ }^{44}$ and in 1950 Jacque Oudot performed the first reconstruction of an occluded aorta in a patient with non-healing ulcers of the left leg using an arterial homograft. ${ }^{45}$ In an attempt to overcome the drawbacks of arterial homografts, such as, limited availability and preservation, and graft degeneration, several surgeons have worked towards the development of fabric arterial grafts. In 1952 , Voorhees reported on the first use of a Vinyon $N$ tube as arterial graft. ${ }^{46}$ Soon thereafter Nylon, Teflon and Dacron grafts were tested. The knitted Dacron prosthesis described by DeBakey and colleagues was the first consistently successful arterial substitute. ${ }^{47}$ The expanded polytetrafluorethylene (PTFE) conduit took graft technology a step further. ${ }^{48}$ \|n addition to the advancement of surgical therapies, minimally invasive, percutaneous techniques were developed for the treatment of peripheral arterial disease. Dotter was the first to relief arterial stenoses using a rigid teflon sound introduced through percutaneous arterial punctures. ${ }^{49}$ Gruentzig improved Dotter's technique by performing the dilatation with the distension of a balloon mounted onto the tip of an intravascular catheter. ${ }^{50}$ Finally, the use of stents has improved long term patency of percutaneous interventions.

\section{3d Visceral ischemia}

Atherothrombotic disease of renall and mesenteric arteries may be associated with ischemic pain, tissue necrosis and organ dysfunction.

Goldblatt et al. have shown that atherosclerotic obstruction of the renal arteries results in reno-vascular hypertension, renal atrophy and loss of renal function. ${ }^{51,52}$ Remarkably, the association between hypertension, albuminuria and granular shrunken kidneys had been described by Bright a century earlier. $^{52}$ Reno-vascular hypertension has been treated initially with simple nephrectomy. ${ }^{53}$ In 1954, while performing an endarterectomy for occlusive aortic disease, Freeman performed the first documented reconstructive renal artery procedure for hypertension. ${ }^{54}$ Many other surgeons have followed revascularising the kidney either by means of endarterectomy or bypass procedures..$^{55,56}$

Chronic mesenteric atherothrombotic disease may be associated with postprandial abdominal pain (angine abdominale) suggestive of intestinal arterial insufficiency but remains asymptomatic in the majority of cases. In an autopsy study, approximately $10 \%$ of unselected specimens demonstrated a significant 
stenosis of at least one of the main intestinal aortic branches. ${ }^{57}$ Despite the high prevalence of asymptomatic mesenteric atherosclerotic disease, chronic mesenteric ischemia manifested by post-prandial abdominal pain is a rare disorder, thereby illustrating the adequacy of the mesenteric collateral circulation. Acute mesenteric ischemia, often on the background of chronic asymptomatic mesenteric disease, characterized by abrupt onset pain, represents an acute abdominal catastrophe with a high mortality. Frequently the severity of pain is out of proportion to the findings at clinical examination.

The first historical description of mesenteric vascular occlusion is attributed to Antonio Beniviene from Florence, Italy in the $15^{\text {th }}$ century. ${ }^{58}$ Although Hodgson described a case of acute intestinal ischemia from Guy's Hospital in $1815^{59}$ the interest of the medical community for this pathology had awaken only after Litten published his classic experimental work on the effect of occlusions of the mesenteric vessels in $1875 .^{60}$ The most important progress in the treatment of this invariably lethal condition was achieved when Elliot reported the first patient who survived an acute mesenteric ischemic event, by resection of the ischemic bowel and creation of two stomas which were re-anastomosed two weeks later. ${ }^{61}$ Thus, the modern concept of diagnosing an acute ischemic bowel by laparotomy and treating it by resection with primary or second stage intestinal re-anastomosis has essentially been unchanged for more than 100 years. The association between abdominal pain and chronic mesenteric occlusion was first laid by Councilman who described three cases of chronic occlusion of the superior mesenteric artery associated with postprandial abdominal pain in $1894 .^{62}$ In 1958, Shaw and Maynard described the first thrombendarterectomy of the superior mesenteric artery for the treatment of acute as well as chronic intestinal ischemia. ${ }^{63}$ Mesenteric revascularization using bypass grafts from the infrarenal aorta to the superior mesenteric artery was first described in 1962 by Morris. ${ }^{64}$ Recently, balloon angioplasties of stenoses of the celiac trunk and superior mesenteric artery have been performed successfully. ${ }^{65}$

\section{3e Aboominal antic anowrsms}

Aneurysms are localised pathologic dilations of arteries, mostly located at the infrarenal part of the abdominal aorta. Other arteries such as the thoracic aorta, the femoral, popliteal and carotid artery may occasionally be affected as well. In their majority, aneurysms remain asymptomatic and are accidentally discovered when screening patients for other purposes. Occasionally patients with aneurysms may present with acute, thrombo-embolic ischemia. Thrombus depositions form in the dilated arterial segment and small thrombus particles may break off and occlude more distal arteries leading to acute ischemic symptoms. Alternatively the weakened wall of aneurysmall arteries may rupture leading to fatal exsanguination of the patient. 
Probably the first account of successful treatment of aneurysms came from Antyllus, a $3^{\text {rd }}$ century Greek surgeon, who had already recognized the distinction between true (degenerative) and false (traumatic) aneurysms. Antyllus advocated opening the (popliteal) aneurysmal sac after applying ligatures directly proximal and distal to the aneurysm. ${ }^{66}$ This technique for the treatment of popliteal aneurysms remained basically unchanged for more than a millennium until John Hunter advocated ligation of the nondilated femoral artery at the level of the subsartorial canal. ${ }^{67}$ This technical improvement led to a significant decrease of post-operative exsanguinating haemorrhage associated with Antyllus' technique. Soon, ligation of other peripheral arteries for aneurysms was reported, such as the brachial artery by Rudolph Matas ${ }^{68}$ and the external iliac artery by John Abernethy. ${ }^{69}$ Sir Astley Cooper was the first to ligate the lower part of the abdominal aorta in an attempt to treat a patient with iliac artery aneurysm. ${ }^{70}$ The specimen of this ligated aorta has been preserved and can be seen to date in the museum at St Thomas' Hospital, London, UK. In order to obliterate aneurysms, unsuccessful attempts were made to induce thrombosis using wires $^{71}$ or electrical currents. ${ }^{68}$ Cellophane wrapping of aneurysms has also been attempted without any longterm success. ${ }^{72}$ Exclusion of a popliteal pseudoaneurysm with direct arterial reconstruction using saphenous vein graft was first performed by James Hogarth Pringle from Glasgow. ${ }^{73}$ Rudolph Matas of New Orleans developed the technique of endoaneurysmorrhaphy for the direct reconstruction of aneurysmal arteries in order to maintain arterial continuity and blood flow. ${ }^{74}$ In 1951, Charles Dubost performed the first successful resection of an infrarenal aortic aneurysm using an arterial homograft to reconstruct the aorta. ${ }^{75}$ Cooley and Debakey introduced the use of artificial (Dacron) conduits for aortic replacement after resection of an aneurysm. ${ }^{47}$ The latest improvement in the treatment of aneurysms is the development of endovascular stentgrafts. With this technique aneurysms can be excluded from the circulation minimal invasively by introducing the stentgraft percutaneously through a puncture of the femoral artery and placing it in the dilated aorta. ${ }^{76,77}$ This technique has already proven to dramatically reduce the mortality of elective and emergency aneurysm repair. ${ }^{78,79}$

\subsection{Epidemiology of atherosclerotic disease}

Cardiovascular disease, mainly resulting from atherosclerosis, is the leading cause of death and disability worldwide. ${ }^{80}$ According to the World Health Report 2003 (available online at http://www.who.int/whr/2003/en/), an estimated $16,700,000$ deaths, i.e., $29.2 \%$ of total global mortality resulted from cardiovascular diseases in $2002 .^{81}$ Additionally, at least $20,000,000$ patients worldwide survived a myocardial infarction or stroke. Cardiovascular morbidity 
and mortality is no longer a prerogative of developed countries. Aproximately $80 \%$ of cardiovascular deaths in 2002 took place in low and middle-income countries. The World Health Organization has estimated that by 2010 cardiovascular disease will be the leading cause of death in developing countries as well. The increase in cardiovascular disease prevalence in developing countries reflects a change in dietary habits, physical activity levels and tobacco consumption worldwide as a result of industrialization, economic development and food market globalization.

Considering the fact that cardiovascular diseases mainly affect people in their productive mid-life years, and taking into account the number of patients surviving myocardial infarctions and strokes that require costly clinical care, the extent of the socio-economic burden of cardiovascular disease becomes evident. More than $50 \%$ of the deaths and disability from cardiovascular disease could be prevented by simple efforts to reduce cardiovascular risk factors. As a matter of fact, modest reductions in major risk factors in England and Wales during the last 20 years resulted in a significant gain in life-years. ${ }^{82}$ Therefore in light of the upcoming global cardiovascular epidemic, identification and elimination of (novel) cardiovascular risk factors seems of enormous importance, both, in global health and socio-economic terms.

The prevalence of cardiovascular diseases in the Netherlands followed the trend of other developed countries, ${ }^{83}$ reaching epidemic proportions in the second half of the $20^{\text {th }}$ century but showing a decrease towards the end of the $20^{\text {th }}$ century. ${ }^{84}$ Table 1.1 shows the estimated prevalences of cardiovascular diseases for the total population in developed countries. For all types of cardiovascular diseases, prevalence is age-dependent and increases almost exponentially with advancing age. Although the number of deaths due to cardiovascular diseases did not change significantly between 1972 and 2002 in the Netherlands (i.e., 50,143 deaths in 1972 vs. 48,799 deaths in 2002), ageadjusted death rates decreased significantly during this period. ${ }^{85}$ Cardiovascular diseases continue to impose a serious burden on national health care budget. The direct and indirect costs of the treatment of coronary artery disease and stroke alone, in 2005 in the USA has been estimated at an excess of $\$ 200$ billion ${ }^{86}$ Of 1.5 million hospital admissions in 2002 in the Netherlands, $18 \%$, i.e. 272,275 were related to cardiovascular diseases. Although adjusted cardiovascular related hospital admissions have declined in the period 1972 2002 , this has been mainly due to the increased percentage of cardiovascular patients treated in day-care setting so that the cost of treatment of cardiovascular diseases in the Netherlands remains high and parallels the US
figures. ${ }^{85}$ 
Table 1.1. Population based prevalence of cardiovascular diseases in developed countries.

\begin{tabular}{ll}
\hline CAD & $6.9 \%^{86}$ \\
CVD & $2.6 \%{ }^{86}$ \\
VID & $0.1 \%-20 \%^{318.319}$ \\
PAD & $0.6 \%-8.8 \%$ \\
AAA & $4.7 \%-7.7 \%^{321}$ \\
\hline
\end{tabular}

CAD: coronary artery disease; CVD: cerebrovascular disease; VID: visceral ischemic disease (i.e., renal artery stenosis and mesenteric ischemia): $\mathrm{PAD}$ : peripheral arterial disease; $A A A$ : abdominal aortic anneurysms.

\subsection{Risk factors for atherosclerosic disease}

Probably one of the most important medical developments of the $20^{\text {th }}$ century has been the identification of risk factors for atherosclerotic disease through large prospective studies such as the Framingham Heart study ${ }^{87}$ and the Seven countries study ${ }^{88}$ Obviously, certain risk factors (i.e. . age, sex) are not amenable to treatment but most of them are very well modifiable. It has been proven that simple measures achieving modest reductions in major risk factors result in significant decrease in atherosclerotic cardiovascular events. ${ }^{82}$ Cigarette smoking, ${ }^{89,90}$ hypercholesterolemia, ${ }^{91}$ low serum HDL cholesterol, ${ }^{92}$ hypertension, ${ }^{93}$ diabetes mellitus ${ }^{94}$ and advancing age ${ }^{95}$ are considered major risk factors and are used in several models to determine cardiovascular risk. $^{96-99}$ Other factors such as obesity, physical inactivity, high serum triglyceride level, ${ }^{100}$ increased serum lipoprotein (a), ${ }^{101}$ hyperhomocysteinemia, ${ }^{102}$ family history of premature atherosclerotic manifestations, ${ }^{103}$ and several coagulation factors, ${ }^{104}$ increase the likelihood for developing atherosclerotic vascular disease but have not been incorporated in current risk prediction equations. Some pathological studies have suggested that only about half of the variation in size of atherosclerotic lesions can be attributed to known risk factors. ${ }^{105,106}$ Similarly, it has been suggested that approximately $50 \%$ of patients with atherosclerotic vascular disease lack any of the major risk factors. ${ }^{107-109}$ However, recently published meta-analyses involving 122,458 patients from 14 randomised clinical trials ${ }^{110}$ and 386,915 patients from three observationall studies ${ }^{111}$ have shown that $80-90 \%$ of patients who develop clinically significant coronary heart disease and as much as $95 \%$ of patients who experienced a fatal coronary event had at least one major cardiovascular risk factor. In view of these statistics, the need to develop "primordial prevention" strategies, i.e., preventing the risk factor to develop, is increasingly being appreciated. ${ }^{112}$

The identification of atherosclerotic risk factors through large epidemiological studies has contributed to the understanding of the causes of atherosclerosis, leading to the formulation of hypotheses regarding its development. The recent 
realisation that atherosclenosis is an inflammatory disease ${ }^{113}$ and that thrombosis is rellated to acute cardiovascular events ${ }^{114}$ has prompted the search for and identification of novel atherothrombotic risk factors. Table 1.2 lists some of the proposed novel risk factors for atherosclerotic vascular disease. It remains to be seen whether they have an additive vallue over conventional risk factors for risk estimation.

Table 1.2 Novel risk factors for atherosclerotic vascullar disease ${ }^{a}$.

\begin{tabular}{lll} 
Inflammatory markers & Thrombotic/haemostatic factors & Other factors \\
\hline Cureactive protein & Fibrinogen & Infectious agents: \\
Serum amyloid A & Von Willebrand factor antigen & C.pmeumoniae \\
Interleukins & Plasminogen activator inhibitor & Cytomegalovirus, \\
Vascular and cellular adhesion & Tissue-plasminogen activator & H.pylori. \\
molecules & D-dimer & Herpes Simplex Virus \\
Soluble CD 40 ligand & Platellet aggregation & Homocysteine \\
Leucocyte count & Platelet activity & insulin resistance \\
Erythrocyte sedimentation rate & Platelet size and volume & Lipoprotein (a)
\end{tabular}

Adapted from Wackam \& Anand. ${ }^{322}$

\subsection{Pathogenesis of atherosclerosis - the inflammatory paradigm}

In his landmark 1999 review, Russel Ross pointed out that atherosclerosis develops as an inflammatory response to endothelial dysfunction. ${ }^{113}$ From the initial atherosclerotic lesion, which is a pure inflammatory lesion as it consists only of monocyte-derived macrophages, to complex plaques, all atherosclerotic lesions represent different stages of a chronic inflammatory process in the artery.

The initial step in atherogenesis is endothelial dysfunction caused by several proatherogenic factors such as oscillating shear stress and turbulent flow, increased and/or modified LDL, hypertension, free radicals caused by smoking, elevated plasma homocysteine levels, certain bacteria and viruses, e.g. Chlamydia pneumoniae and Cytomegalovirus, and combinations of these and other factors. ${ }^{13}$ These initiating stimuli result in increased endothelial permeability, increased endothelial adhesiveness for leucocytes or platelets, development of endothelial procoagulant instead of anticoagulant properties and production of vasoactive molecules, cytokines and growth factors. ${ }^{13}$ One of the earliest events in atherosclerosis is the retention of LDL in the subendothelial matrix where it undergoes modification. ${ }^{115}$ Modified LDL stimulates the overlying endothelium to produce a number of pro-inflammatory molecules, such as growth factors and adhesion molecules. Being a potent chemoattractant for monocytes $^{116}$ and a mitogen for macrophages ${ }^{117}$ and 
smooth muscle cells, ${ }^{118}$ modified LDL contributes to inflammation and foam cell formation. Under it's influence, monocytes and specific subsets of T-cells are attracted to the subintimal space. ${ }^{119}$ Macrophages rapidly take up modified LDL becoming foam-cells and leading to fatty streak formation. ${ }^{120}$ The ongoing inflammatory response stimulates migration and proliferation of smooth muscle cells, leading to intermediate, preatheromatous type Itll lesions. If unabated, the inflammatory reaction results in further influx of macrophages and T-cells. proliferation of smooth muscle cells and apposition of extra-cellular matrix. Through the action of an array of inflammatory molecules such as hydrolytic enzymes, chemokines, and cytokines the lesions evolve into advanced (fibro)atheromatous and/or unstable plaques. ${ }^{13,121}$

\subsection{Atherosclerosis and C-reactive protein}

In view of the inflammatory nature of atherosclerosis, several investigators have studied inflammatory molecules as markers of atherosclerosis (see Table 1.2). Arnong the plethora of analysed inflammatory markers, C-reactive protein (CRP) has been studied most extensively and has shown the most consistent association with atherosclerotic events in diverse clinical settings. CRP is an acute phase reactant present in trace concentrations in healthy subjects $(<1 \mathrm{mg} / \mathrm{l})$. Its concentration can increase up to a 1,000-fold in response to infection, ischemia, trauma, burns and (acute) inflammatory conditions. ${ }^{122,123}$ The development of high sensitivity CRP (hsCRP) assays has facilitated the analysis of the role of CRP in atherosclerotic vascular disease, ${ }^{124,125}$ as $h s C R P$ levels below $10 \mathrm{mg} / \mathrm{l}$ have demonstrated specificity for vascular events. ${ }^{126}$ It has been shown that serum $h S C R P$ is elevated in patients with coronary artery disease $e^{127-133}$ and that in these patients, as well as in patients with peripheral arterial disease, serum hsCRP is related to (cardiovascular) mortality ${ }^{134-136}$ and future coronary events. ${ }^{104,137-145}$ Furthermore, several prospective and nested case control studies have shown that a single, non-fasting measure of serum hsCRP is strongly associated with the development of coronary, ${ }^{146-157}$ cerebral, ${ }^{147,958,159}$ and peripheral ${ }^{160}$ vascular events, in apparently healthy, middle-aged and elderly individuals. These studies have established CRP as an independent predictor of future cardiovascular events that adds prognostic information to lipid screening, and to Framingham Risk Score. ${ }^{161}$ Recently, evidence has emerged to show that primary and secondary preventive strategies are most effective in patients with elevated serum hsCRP levels suggesting that lowering CRP may reduce cardiovascular event rates. The risk reduction for aspirin was higher in patients with elevated baseline serum hsCRP. ${ }^{147}$ This may suggest that aspirin has clinically important antiinflammatory as well as antiplatelet effects. Nevertheless, the CRP-lowering properties of aspirin remain controversial. ${ }^{133,162}$ In contrast, statins 
(hydroxymethyl glutaryl coenzym A reductase inhibitors) have shown to be able to reduce serum hsCRP concentrations as well as plasma cholesterol levels, ${ }^{163-}$ ${ }^{166}$ and that both in the setting of primary (AFCAPS/TexCAPS primary prevention trial) ${ }^{167}$ and secondary prevention (CARE), ${ }^{163}$ the effect of statins on cardiovascular risk reduction was most pronounced in patients with high hsCRP levels. Recently published data of a randomised clinical trial has shown that among patients with acute coronary syndromes, statin treatment achieving low level of hSCRP ( $<2 \mathrm{mg} / \mathrm{l})$ was associated with a significant improvement in event-free survival. This effect was present at all levels of LDL cholesterol achieved and suggested that strategies designed to reduce inflammation may improve cardiovascular outcome. ${ }^{168}$

Assuming that CRP is produced by hepatocytes after stimulation with interleukin-6 and interleukin $1 \beta^{169}$, the association between serum hsCRP and cardiovascular disease may reflect (i) the amount of circulating proinflammatory (pro-atheroslerotic) cytokines, (ii) vascular inflammation related to the extent and severity of atherosclerosis, (iii) (vascular) inflammation resulting from chronic (vascular) infections, and (iv) inflammation related to tissue (heart, brain, skeletal muscle) ischemia. However, CRP is an ancient host defence protein whose phylogenetic origins can be traced as far back as the horseshoe crab (Limulus polyphemus). ${ }^{170}$ Therefore it would be anticipated that many tissues of the body would preserve their ability to generate this protein as part of their innate immune defences. Intriguingly, it has been shown that various types of damaged tissues, such as Alzheimer's disease brains, ${ }^{171,172}$ infarcted hearts, ${ }^{173}$ and coronary atherosclerotic plaques ${ }^{174}$ produce CRP. Since CRP can be found in atherosclerotic tissue ${ }^{175}$ and lowering hsCRP results in atherosclerotic event-reduction ${ }^{160}$ it may well be suggested that CRP could actually participate in the development of atherothrombosis. In support of this hypothesis, in vitro experiments have shown that CRP exerts pro-atherogenic effects on all cellular constituents of the atherosclerotic lesion. CRP colocalizes with the membrane attack complex in atherosclerotic plaques and activates complement. ${ }^{174,176}$ It is chemotactic for circulating monocytes and CRP plaque deposits actually precede the appearance of monocytes, suggesting that it may play a major role in the recruitment of monocytes during atherogenesis. ${ }^{177}$ Furthermore, CRP stimulates monocyte tissue factor production $^{178}$ and up-regulates some macrophage pro-inflammatory cytokines. ${ }^{179}$ CRP causes a sustained increase in native LDL-uptake by macrophages ${ }^{180}$, possibly through uptake of CRP-opsonized native LDL via the CRP-receptor CD32. ${ }^{181}$ Through activation of nuclear factor kappa B of endothelial and smooth muscle cells, CRP may induce pro-inflammatory and pro-atheroscleratic phenomena. CRP may thus induce endothelial production of adhesion molecules, ${ }^{182}$ stimulate endothelial monocyte chemoattractant protein-1 release, ${ }^{183}$ and may inhibit basal and stimulated endothelial NO 
release. ${ }^{184}$ Similarly, CRP activates monocyte chemoattractant protein-1, interleukin- 6 and inducible nitric oxide synthetase expression in vascular smooth muscle cells. ${ }^{185}$

\subsection{Atherosclerosis and infections}

The notion that infections play an important role in the development of atherosclerosis is surprisingly old. At the beginning of the previous century, it had already been suggested that infections may contribute to the development of cardiovascular disease. ${ }^{186-188}$ During the interbellum, Collins observed that every influenza epidemic was followed by an increase in cardiac deaths. ${ }^{189}$ Nevertheless, experimental evidence supporting this hypothesis only came available when half a century later Fabricant showed that infection of chickens with Marek's disease virus, an avian herpes virus, produces typical atherosclerotic lesions. ${ }^{190}$ Subsequently, and in accordance with the early observations of Selwyn Collins, clinicians had observed that acute (respiratory tract) infections were associated with coronary events. ${ }^{191-194}$ Several pathogens have been related to the development of cardiovascular disease, such as the herpesviridae cytomegalovirus, ${ }^{195}$ Epstein-Barr virus and herpes simplex virus, ${ }^{196}$ Helicobacter pylori, ${ }^{197,198}$ the periodontal pathogens Streptococcus sanguis, ${ }^{199}$ Porphyromonas gingivalis, Actinobacillus actinomycetemcomitans, Bacteroides forsythus, and Prevotella intermedia, ${ }^{200}$ hepatitis A virus. ${ }^{201}$ influenza virus ${ }^{202-204}$, Coxsackie B virus, ${ }^{205}$ and Chlamydia pneumoniae. ${ }^{193.206}$ The latter has been studied most extensively in relation to atherosclerosis, not in the last place because two early small antibiotic intervention trials had suggested that antichlamydial treatment may reduce cardiovascular risk in patients with coronary artery disease. ${ }^{207,208}$

\section{8 a Chlamydia pheumoniae biology \& epidemiology}

Chlamydia pneumoniae was initially isolated in 1965 from a child's conjunctiva as an atypical strain that could not be identified as Chlamydia trachomatis. ${ }^{209} \mathrm{~A}$ similar atypical chlamydial strain was isolated from the pharynx of a patient with an upper respiratory tract infection in $1983 .{ }^{210}$ In 1989 , these atypical isolates were recognized as a new chlamydial species that was named Chlamydia pneumoniae. ${ }^{211}$ It is an obligate intracellular, Gram-negative microbe with a typical chlamydial developmental life cycle of two alternating functional and morphological forms (Figure 1.2). ${ }^{212}$ The small, dense elementary body (EB) is the metabolically inactive, highly infectious form of the microbe, responsible for attaching to the target host cell. After attachment to the host cell, the EB transforms, within an endosome, into the larger, metabolically active reticulate body (RB) that divides by binary fission within the endosome. After a period of growth and division, the RBs reorganize into EBs and cause lysis of the host 
cell thereby completing the developmental cycle. The released EBs may initiate new infectious cycles. Under certain conditions Chlamydiae may follow an altered intracellular development. Nutrient deficiency, several antimicrobial agents and cytokines may delay RB maturation and inhibit differentiation into EBs, giving rise to a morphologically altered RB form which occasionally is referred to as persistent body. ${ }^{213}$ Re-establishment of a favourable milieu will allow persistent bodies to re-enter and complete the normal chlamydial developmental cycle (Figure 1.2).

Chlamydia pneumoniae causes community acquired respiratory tract infections. ${ }^{214}$ Among adults with community acquired pneumonia, Chlamydia pneumoniae was the causative agent in approximately $3-50 \% .^{215-218}$ Considering the high prevalence of Chlamydia pneumoniae lgG antibody in the general population, which may be as high as $80 \%$ in octogenarians, ${ }^{219}$ it is not surprising that up to $90 \%$ of Chlamydia pneumoniae respiratory tract infections may remain asymptomatic. ${ }^{220,221}$ This high antibody prevalence may be the result of frequent reinfections and suggests that virtually everyone will at least once get infected with Chlamydia pneumoniae during his/her lifetime. ${ }^{222}$

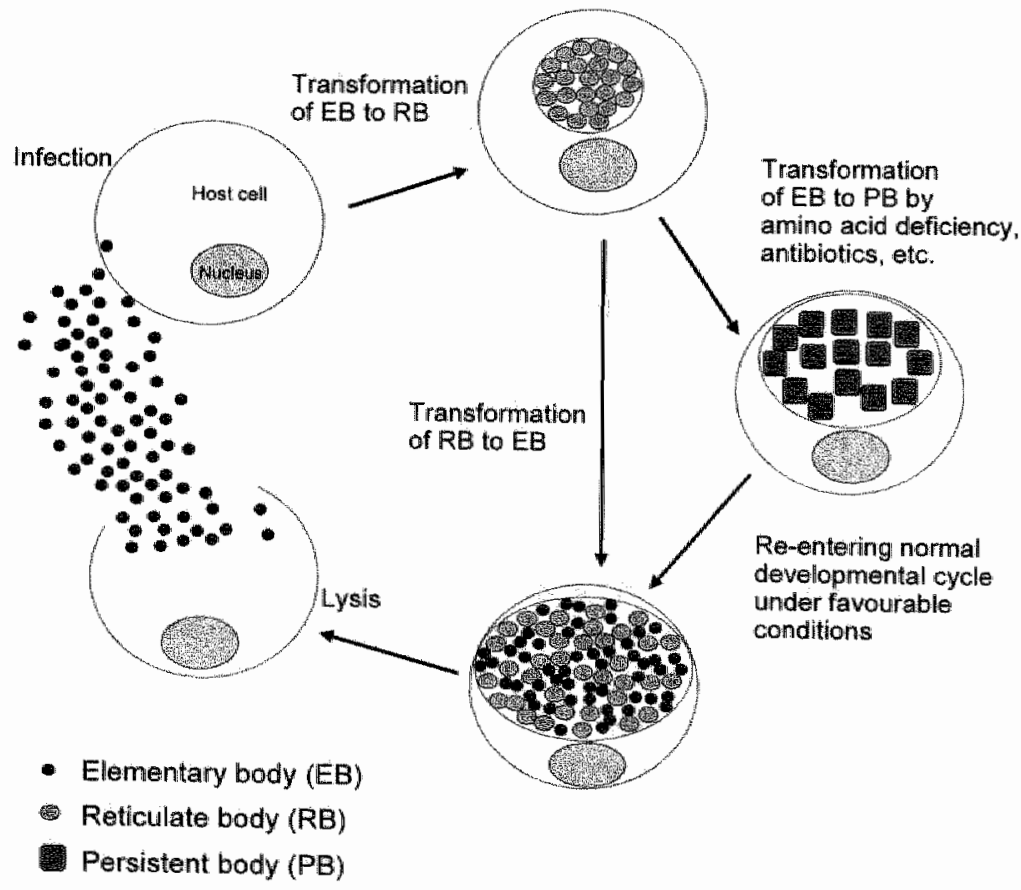

Figure 1.2 The developmental cycle of Chlamydia preumoniae. 


\subsection{Chlamydia pneumoniae and atherosclerosis}

in the early 1940's several investigators showed that patients with cardiovascular disease and without any history of lymphogranuloma venereum often demonstrated a positive intradermal Frei test, which measures hypersensitivity to all chlamydial species, thereby providing the first hint that chlamydial infections may be related to arterial disease. ${ }^{223-225}$ The last 20 years ample evidence has gathered to suggest that Chlamydia pneumoniae infections play a (modulatory) role in the development of atherosclerosis. ${ }^{226}$

\section{8b.1 Sero-epidemiological evidence}

Since Saikku and colleagues have shown that Chlamydia pneumoniae antibodies were elevated in patients with acute myocardial infarction or stable coronary artery disease, ${ }^{193}$ a large number of studies have explored the relation between Chlamydia pneumoniae serology and atherosclerotic disease, determining Chlamydia pneumoniae antibodies or immune-complexes in patients with coronary, carotid, aortic, and peripheral arterial disease and healthy controls. Although a few studies failed to verify the association between infection and atherosclerosis, ${ }^{227}$ the majority of these studies supported an association between Chlamydia pneumoniae serology and atherosclerosis. ${ }^{228-}$ ${ }^{231}$ Despite the numerous sero-epidemiological reports, no consensus has been reached regarding the serological detection of chronic active or persistent

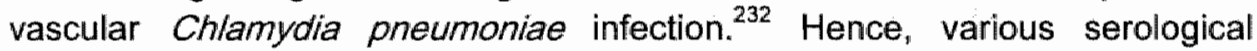
assays and different serological criteria for chronic or persistent Chlamydia pneumoniae infection have been used insofar leading to the conflicting results of hitherto published studies. Standardization of Chlamydia pneumoniae detection assays in patients with cardiovascular disease has therefore become mandatory.

\section{8b.ll Histological evidence}

Traces of Chlamydia pneumoniae have been found abundantly in human atherosclerotic tissue. ${ }^{233}$ Chlamydia pneumoniae proteins and/or DNA have been detected in more than $50 \%$ of atherosclerotic specimens using immunohistochemical techniques or $\mathrm{PCR}$, respectively. Although Chlamydia pneumoniae seems ubiquitously present in the atherosclerotic vascular tree, as it has been detected in atheroma derived from any vascular territory, i.e., coronary, carotid, aortic, femoral and popliteal, no traces of the bacterium could be found in normal arteries. ${ }^{234,235}$ The prevalence of chlamydial presence in atherosclerotic tissue varies considerably. ${ }^{236}$ Detection rates ranging from 0 to $100 \%$ have been reported. ${ }^{237}$ Despite this variation, the frequent finding of Chlamydia pneumoniae in atherosclerotic plaques and not in normal tissue strongly suggests that the organism is undeniably present in atherosclerotic lesions and supports an association with atherosclerosis, although the 
presence of the microbe in atheroma has not invariably been associated with severity or extent of the disease. ${ }^{236,239}$

\subsubsection{Experimental evidence}

Chlamydia pneumoniae shows a strong tropüsm for macrophagles, but has proven to infect and survive in endothelial cells and smooth muscle cells as well. ${ }^{240}$ This suggests that local infection of the vasculature may provide a focus for in-situ vascular damage promoting a pro-atherogenic inflammatory response.

The microbe may gain access to the vasculature after respiratory tract infections through infected monocytes. ${ }^{241}$ Indeed, in vitro experiments have shown that monocytes infected with Ch/amydia preumoniae exhibit enhanced plasma membrane fluidity ${ }^{242}$ and adherence to human endothelial cells, ${ }^{243}$ resulting in transmission of the pathogen to endothelial cells. ${ }^{242,244}$ Infection of macrophages with Chlamydia pneumoniae induces excessive LDH uptake leading to foam cell formation. ${ }^{245}$ Lipopolysaccharide (LPS) has been shown to be the chlamydial component that induces foam cell formation. ${ }^{246}$ By means of its Heat shock protein 60 (HSP-60), Chlamydia preumoniae induces monocytes to oxidize lipoproteins. ${ }^{247,248}$ Furthermore, infected macrophages secrete increased levels of inflammatory cytokines (interleukin (IL)-1 $\beta$, IL-6, tumor necrosis factor- $\alpha$, interferon- $\gamma,{ }^{249}$ monocyte chemoattractant protein-1 (MCP-1) and macrophage inflammatory protein-1 $\alpha$ (MIP-1 $\alpha))^{250}$ and matrix metalloproteinase-9 (MMP-9). ${ }^{251,252}$

Chlamydia pneumoniae upregulates atherosclerosis-related gene expression in human umbilical vein endothelial cells. ${ }^{253,254}$ Infection of endothelial cells augments endothelial adhesion molecule expression providing additional means for the promotion of monocyte adherence to the endothelial surface. ${ }^{255}$ Furthermore, Chlamydia pneumoniae infection causes endothelial dysfunction, ${ }^{256}$ stimulates transendothelial migration of inflammatory cells, ${ }^{257}$ induces endothelial hypercoagulability through increased expression of tissue factor, ${ }^{258,259}$ and promotes endothelial secretion of inflammatory mediators. ${ }^{260}$

Smooth muscle cells respond to endothelial Chamydia pneumoniae infection by proliferating. ${ }^{261}$ Direct infection of smooth muscle cells also has a mitogenic effect, possibly through induction of endogenous heat shock protein, 262.263 inthibits apoptosis ${ }^{264}$ and induces secretion of cytokines ${ }^{259,265}$ and matrix metalloproteinases. ${ }^{266}$.

Studies using cholesterol fed New Zealand white rabbits, ${ }^{267.268}$ several mouse strains, ${ }^{259}$ rats $^{270}$ and pigs ${ }^{271}$ have supported the atherogenic properties of Chlamydia pneumoniae infection. Although two investigators reported a lack of association between experimental Chlamydia pneumoniae infection and development of atherosclerosis, ${ }^{272,273}$ the majority of animal studies has shown that Chlamydia pneumoniae has a tropism for the vasculature and the capacity 
to initiate or promote atherosclerotic lesion development. Repeated inoculations and a hyperlipidemic background were prerequisites for the demonstration of the atherogenic properties of Chlamydia pneumoniae. After intranasal inoculation, Chlamydia pneumoniae reaches distant organs, including the arteries, by infected macrophages. ${ }^{241.274}$ in hyperlipidemic mice ${ }^{275.276}$ and cholesterol fed New Zealand white rabbits, ${ }^{267.268}$ Chlamydia pneumoniae infection accelerated atherosclerotic lesion development. In contrast, in normolipidemic animals, infection did not induce plaque formation although in these circumstances arterial inflammatory reactions were observed. ${ }^{277,278}$ Furthermore, infected animals showed more advanced atherosclerotic lesions, ${ }^{276,279}$ and unstable plaque phenotypes. ${ }^{280}$ Experimental Chlamydia pneumoniae infection has been associated with endothelial dysfunction, ${ }^{256}$ increased fibrinogen activity, ${ }^{281}$ and increased gelatinolytic activity. ${ }^{280}$ Antibiotic treatment of experimental animals infected with Chlamydia pneumoniae ameliorated the progression of atherosclerotic lesions, but only when administered shortly after inoculation. ${ }^{268,282}$

\section{8b.IV Antibiotic trials}

The sero-epidemiological and experimental data showing an association between Chlamydia pneumoniae infection and atherosclerosis triggered the interest of (cardio)vascular clinicians for this pathogen based on the premises that anti-chlamydial antibiotics may offer a new treatment modality for patients with atherosclerotic vascular disease. Indeed, two early small randomised clinical trials suggested that antibiotics may reduce cardiovascular risk in patients with coronary artery disease. ${ }^{207,208}$

Several investigators have tried to evaluate the effect of antibiotics on cardiovascular risk by observational case-control studies. A number of these studies showed a survival benefit from exposure to anti-chlamydial antibiotics, ${ }^{283-286}$ although others refuted it. $^{287-291}$ Considering the methodological shortcomings of these studies, randomised clinical trials were needed to determine the effectiveness of antibiotics in atherosclerotic disease prevention. Following the two initial positive pilot studies a number of antibiotic trials have been designed and carried out worldwide with contradictory resuits. ${ }^{292-308}$ In general, favourable results were shown in studies with small sample size and/or limited follow-up, ${ }^{207,208,298.299,309}$ studies that have included patients with abdominal aortic aneurysms ${ }^{296: 297}$ or peripheral arterial disease, ${ }^{300}$ or studied surrogate endpoints. ${ }^{293,301,302,307}$ Three larger studies, involving patients with coronary artery disease, demonstrated no beneficial effect of antibiotics in the prevention of acute coronary events and/or death. ${ }^{303-305}$ 


\section{8b.V Mechanism of disease}

The available data suggest that Chlamydia pneumoniae may play a (modulatory) role (i) in the initiation of atherosclerosis through stimulation of inflammatory cell recruitment and foam cell formation, (ii) in the progression of atherosclerosis through stimulation of smooth muscle cell proliferation and inhibition of apoptosis, and (iii) in the development of an unstable plaque through stimulation of collagenase activity and induction of hypercoagulability, mainly by virtue of its in situ effects. Next to its presumed local effects, Chlamydia pneumoniae may promote atherosclerosis through systemic effects. Chronic Chlamydia pneumoniae infection may induce a chronic inflammatory state characterized by elevated levels of pro-inflammatory and pro-atherogenic molecules, and/or a hypercoagulable state characterized by raised fibrinogen levels. ${ }^{310,311}$ Furthermore, infection may trigger an autoimmune reaction to human HSP-60 by antigenic mimicry resulting in endothelial cytotoxicity ${ }^{312}$ which has been associated with enhanced development of atherascierosis. ${ }^{313}$ Finally, infection may be associated with atherosclerosis through interaction with atherosclerotic risk factors such as smoking ${ }^{314}$ lipid metabolism, ${ }^{315,316}$ and hypertension. ${ }^{317}$ Considering the high prevalence of exposure to Chlamydia pneumoniae among patients with atherosclerotic vascular disease and age matched healthy controls, it is conceivable that host factors, such as variations in genes involved in inflammatory processes, may render individuals susceptible for the pro-atherogenic effects of infection. 


\subsection{Aims of the study and outline of the thesis}

Atherosicerosis has emerged as a multi-factorial inflammatory process of the vascular wall. It is unlikely that one inflammatory molecule (C-reactive protein) and one pathogen (Chlamydia pneumoniae) alone can initiate or propagate the development of atherosclerosis. Keeping this in mind, the primary goal of this study was to assess the role of C-reactive protein and Chlamydia pneumoniae infection in patients with (non-coronary) atherosclerotic disease.

The relation between CRP and peripheral arterial disease or abdominal aortic aneurysms is dealt with in section 2 (chapters 2, 3). Chapter 2 describes the association between serum concentration of CRP and severity of peripheral arterial disease and future cardiovascular events in patients with PAD. In chapter 3 the relation between serum CRP and extent of abdominal aortic aneurysms is studied. Furthermore, the production of CRP by diseased vascular tissue was explored in these chapters.

In section 3 (chapters $4,5,6$ ) the role of Chlamydia pneumoniae infection in peripheral vascular disease was studied. In chapter 4, the use of a commercially available enzyme immunoassay for the detection of Chlamydia pneumoniae lgA- and IgG-antibodies in patients with cardiovascular disease is validated against the gold standard serological assay.. The association between Chlamydia pneumoniae antibodies and presence of the pathogen in atherosclerotic tissue is assessed in chapter 5. Furthermore the relation between the extent of atherosclerotic disease and antibady titers or presence of the pathogen in atherosclerotic tissue is analysed. Considering the reported association between Chlamydia pneumoniae antibodies and cardiovascular events, and bearing in mind that plaque destabilization (i.e., plaque rupture or ulceration) and thrombus formation underly acute cardiovascular events, we explored whether Chlamydia pneumoniae is more likely to induce plaque instability or a hypercoagulable status. This question is answered in chapter 6 using an in vivo model that allows to differentiate between placue instability and hypercoagulability, i.e. the patient undergoing carotid endarterectomy for symptomatic carotid artery disease.

In section 4 (chapter 7), host factors potentially accounting for individual susceptibility to the pro-atherogenic properties of infection are studied. In chapter 7 , the association between common polymorphisms of two patternrecognition receptor genes (Toll-like Receptor 4 and CD14) and extent of atherosclerotic disease is analysed in patients with peripheral arterial disease.

The infectious and inflammatory paradigm for atherosclerosis development offers new potential therapeutic targets. In section 5 the effect of a short course of antibiatics in the progression of atherosclerosis in patients with PAD was studied in a randomised clinical trial (chapter 8). Finally, the data presented in this thesis are discussed and put in perspective in section 6 (chapter 9). 


\section{References}

1. McMillan GC. Nature and definitions of atherosclerosis. Ann N Y Acad Sci. 1985;454:1-4.

2. Stary $\mathrm{HC}$. Natural history and histological classification of atherosclerotic lesions: an update. Arterioscler Thromb VasC Biol. 2000;20:1177-8.

3. Napoli $C$, D'Armiento FP, Mancini FP. Postiglione $A$, Witztum $J L$, Palumbo $G$, Palinski $W$. Fatty streak formation occurs in human fetal aortas and is greatly enhanced by maternal hypercholesterolemia. Intimal accumulation of low density lipoprotein and its oxidation precede monocyte recruifment into early atherosclerotic lesions. I clin invest. $1997: 100: 2680-90$

4. Stary HC. Macrophages, macrophage foam cells, and eccentric intimal thickening in the coronary arteries of young children. Atherosclerosis. 1987;64:91-108.

5. Stary HC. Lipid and macrophage accumulations in arteries of children and the development of atherosclerosis. Am J Clin Nutr. 2000;72:1297S-306S.

B. Stary $H_{i}$ Chandler $A B$, Glagov $S$, Guyton $J R_{*}$ Insull $W$, Jr, Rosenfeld ME, Schaffer $S A$, Schwartz CJ, Wagner WD, Wissler RW. A definition of initial, fatty streak, and intermediate lesions of atherosclerosis. A report from the Committee on Vascular Lesions of the Council on Arteriosclerosis, American Heart Association. Circulation. 1994;89:2462-78.

7. Stary HC, Blankenhorn DH, Chandler $A B$, Glagov S, Insull W, Jr., Richardson M, Rosenfeld ME, Schaffer SA, Schwartz Cu, Wagner WD, et al. A definition of the intima of human arteries and of its atherosclerosis-prone regions. A report from the Committee on Vascular Lesions of the Council on Arteriosclerosis, American Heart Association. Circulation. 1992;85:391-405.

8. Stary HC. Evolution and progression of atherosclerotic lesions in coronary arteries of children and young adults. Arteriosclerosis 1989:9:119-32.

9. Katz SS, Shipley GG, Small DM. Physical chemistry of the lipids of human atherosclerotic lesions. Demonstration of a lesion intermediate between fatty streaks and advanced plaques. I Clin /nvest. 1976;58:200-114.

10. Daoud $A S$, Jarmolych J. Augustyn $M_{M}$, Fritz KE, Singh JK, Lee KT. Regression of advanced atherosclerosis in swine. Arch Patho/ Lab Med. 1976;100:372-9.

11. Sukhova GK, Williams JK, Libby $P$. Statins reduce inflammation in atheroma of nonhuman primates independent of effects on serum cholesteroil. Arterioscler Thromb Vasc Biol. 2002;22:1452-8.

12. Stary HC. Regression of atherosclerosis in primates. Wirchows Arch A Pathol Anat Histol. $1979 ; 383: 117-34$

13. Crisby Ml, Nordin-Fredriksson G, Shath PK, Yano J, Zhu J, Nilsson J. Pravastatin treatment increases collagen content and decreases lipid content inflammation, metalloproteinases. and cell death in human carotid plaques: implications for plaque stabilization. Circulation. 2001:103:926-33

14. Crouse JR, 3rd, Byington RP. Bond MG, Espeland MA, Craven TE, Sprinkle JW, McGovern ME, Furberg CD. Pravastatin, Lipids, and Atherosclerosis in the Carotid Arteries (PLAC-11). Am J Cardiol 1995;75:455-9.

15. Furberg CD. Adams HP, JT, Applegate WB, Byington RP, Espeland MA, Hartwell $T$, Hunninghake DB, Lefkowitz DS, Probstfield J, Riley WA, et al. Effect of lovastatin on early carotid atherosclerosis and cardiovascular events. Asymptomatic Carotid Artery Progression Study (ACAPS) Research Group. Circulation. 1994;90:1679-87.

16. Smilde $T d$, van Wissen $S$, Wollersheim $H$, Trip MD, Kastelein $J J$, Stalemhoef AF. Effect of aggressive versus conventional lipid lowering on atherosclerosis progression in familial hypercholesterolaemia (ASAP): a prospective, randamised, double-blind trial. Lancet. 2001; 357:577-81

17. Xu C. Zarins CK, Glagov 5 . Aneurysmal and acclusive atherosclerosis of the human abdominal aorta. $J$ Vasc Surg. 2001;33:91-6.

18. Heberden W. Some account of a disorder of the breast. In: Medical Transactions. London: Royal College of Physicians; $\$ 772: 59-67$. 
19. Parry $\mathrm{CH}$. An inquiry into the symptoms and causes of the syncope anginosa, commonly called angina pectoris; illustrated by dissections. London (UK). R. Crutwell. 1799:4-167.

20. Herrick JB. Clinical features of sudden obstruction of the coronary arteries. JAMA. 1912:59:2015-20.

21. Fletcher $A P$, Alkjaersig $N$, Smyrniotis $F E$, Sherry $S$. The treatment of patients suffering from early myocardial infarction with massive and prolonged streptokinase therapy. Trans AssoC Am Piyssicians. 1958;71:287-96.

22. Effectiveness of intravenous thrombolytic treatment in acute myocardial infarction. Gruppo Italliano per lo Studio della Streptochinasi nell'Infarto Miocardico (GISSi). Lancet. 1986:1: $397-402$

23. Effler DB, Groves $L K$, Sones FM, Jr., Shirey EK. Endarterectomy in the Treatment of Coronary Artery Disease. I Thorac Cardiovasc Surg. 1964;47:98.108.

24. Garrett HE, Dennis EW, DeBakey ME. Aortocoronary bypass with saphenous vein graft. Seven-year follow-up. JAMA. 1973;223:792-4.

25. Favaloro RG. Saphenous vein autograft replacement of severe segmental coronary artery occlusion: operative technique. Ann Thorac Surg. 1968;5:334-9.

26. Favaloro RG, Effler DB, Groves LK, Sheldon WC, Shirey EK, Sones FM, Jr. Severe segmental obstruction of the left main coronary artery and its divisions. Surgical treatment by the saphenous vein graft technique. I Thorac Cardiovasc Surg. 1970;60:469-82.

27. Gruentzig A, Senning A, Siegenthaler W. Nonoperative dilatation of coronary-artery stenosis: percutaneous transluminal coronary angioplasty. N Engl J/Med. 1979;301:61-8.

28. Sigwart U, Puel J, Mirkovitch V, Joffre F, Kappenberger L. Intravascular stents to prevent occlusion and restenosis after transluminal angioplasty. N Engl J Med 1987;316:701-6.

29. Bogousslavsky J, Van Melle $G$, Regli $F$. The Lausanne Stroke Registry: analysis of 1,000 consecutive patients with first stroke. Stroke. 1988;19:1083-92.

30. Gurdjian ES. History of occlusive cerebrovascular disease I. from Mepfer to Moniz. Arch Neurol. 1979;36:340-3.

31. Penzoldt F. Uber thrombose (autachtone oder embolische) der carotis. Disch Arch fKlin Aled. $1881 ; 28: 80-93$.

32. Osler W. The principles and practice of medicine. 7th ed. New York, NY: Applieton and Co: 1909.

33. Hunt JR. The role of the carotid arteries in the causation of vascular lesions of the brain, with remarks on certain special features on the symptomatology. Am \& Med Sci 1914;147: 704-13.

34. Fisher M. Occlusion of the carotid arteries: further experiences. AMA Arch Newrol Psychiatry. 1954;72:187-204

35. DeBakey ME. Successful carotid endarterectomy for cerebrovascular insufficiency. Nineteenyear follow-up. JAMA. 1975;233:1083-5.

36. Eastcott HH, Pickering GW, Rob CG. Reconstruction of internal carotid artery in ai patient with intermittent attacks of hemiplegia. Lancet. 1954;267:994-6.

37. Randomised trial of endarterectorny for recently symptomatic carotid stenosis: final results of the MRC European Caratid Surgery Trial (ECST). Lancet. 1998;351:1379-87.

38. Endarterectomy for asymptomatic carotid antery stenosis. Executive Committee for the Asymptomatic Carotid Atherosclerosis Study. JAMA. 1995;273:1421-8.

39. Tissue plasminogen activator for acute ischemic stroke. The National Institute of Neuralogical Disonders and Stroke rt.FA. Stroke Study Group. N Eng/ J Med. 1995;333:1581-77.

40. Sugar $O$. Jean-Francois Bouley (Bouley jeune). Pioneer investigattor in intermittent claudication. Spine 1994;19:346-9.

41. dos Santos JC. Sur la desobstruction des thromboses arterielles anciennes. Mem Acad Chir. $1947 ; 73: 409$.

42. Kunlin J. Le traitement de l'arteite obliterante par la greffe veineuse longue. Arch de ma/ du coeur. 1949:42:371.

43. Murphy JB. Resection of arteries and weins injured in continuity. Med Rec. 1897:51:73.

44. Gross RE, Hurwitt ES, Bill AHJ, II PEC. Preliminary observation on the usie of human arterial grafts in the treatment of certain cardiovascular defects. N Eng/ /Med 1948;239:78. 
45. Oudot J. La greffe vasculaire dans les thromboses du carrefour aortique. Presse Med. $1951: 59: 234-6$

46. Voorhes $\mathrm{ABJ}$, Jaretzki $\mathrm{Ar}$, Blakemore $\mathrm{AH}$. The use of tubes constructed from vinyon " $\mathrm{N}$ " cloth in bridging arterial defects. Ann Surg. 1952;135:332-6.

47. Debakey ME, Cooley DA, Crawford ES, Morris GCJ. Clinical application of a new flexible knitted dacron arterial subistitute. Arch Surg. 1957;74:944.

48. Soyer $T$, Lempinen $M$ "Cooper $P$, Norton $L$, Exseman B. A new venous prosthesis. Surgery. $1972,72 \cdot 864-72$

49. Dotter CT, Judkins MP. Transluminal Treatment of Arteriosclerotic Obstruction. Description of a New Technic and a Preliminary Report of its Application. Circulation. 1964:30:65.4-70.

50. Gruenitzig A, Hopff H. Perkutane Rekanalisation chronischer arterieller Verschlusse mit einem meuen Dilatationskatheter: Modifikation der Dotter-Technik. [Percutaneous recanallization after chronic arterial occlusion with a new dilator-catheter: modification of the Dotter technique (author's transl)]. Dtsch Med Wachenschir. 1974;99:2502-10.

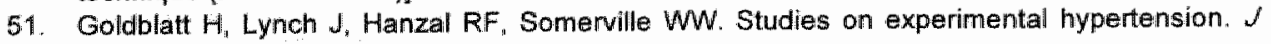
Exp Med. 1934:59:347.

52. Bright $R$. Cases and observations illustrative of renal disease accompanied with the secretion of albuminous urine. Guj's Hosp Rep 1836;1:388.

53. Smith HW. Unilateral nephirectomy in hypertensive disease. J Urof 1956;76:685-701.

54. Freeman NE, Leeds FH, Elliot WG, Roland SI. Thromboendarterectomy for hypertension due to renal artery occlusion. JAMA. 1954:156:1077-9.

55. Poutasse EF. Surgical treatment of renal hypertension: results in patients with occlusive Jesions of renal arteries. JUrol $1959 ; 82: 403-11$.

56. Stanley JC, Enst CB, Fry WJ. Fate of 100 aortorenal vein grafts: characteristics of late graft expansion, aneurysmal dilatation, and stenosis. Surgery, 1973;74:931-44.

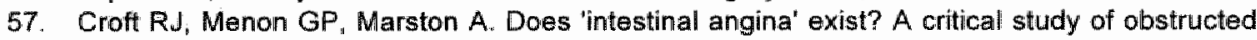
Wiscerall arteries. Br J Surg. 1981;68:316-8.

58. Allbutt $\mathrm{C}$. Rolleston $\mathrm{H}_{1}$ eds. A system of Medicine by many Writers, vol 3: General Diseases of Obscure Origin, Diseases of the Alimentary Camal and Peritoneum. London: Macmillan; 1910.

59. Hodgson ل J. Treatise on the Diseases of Arteries and Veins, containing the Pathology and Treatment of Aneurysms and Wounded arteries. London: T Underwood; 1815.

60. Litten $\mathrm{H}$. Uber die Folgen des Verschlusses der Arteria Mesenterica Superior. Arch Parthot Anat. 1875;63:289-94.

61. Elliot JW. The operative relief of gangrene of the intestine due to occlusion of the mesenteric vessels. Ann Surg: 1895;21:9-12.

62. Councilman WT. Three cases of occlusion of the superior mesenteric artery. Bostan Medical and Surgical Journat. 1894;130:410-1.

63. Shaw RS, Maynard EP. 3rd. Acute and chronic thrombosis of the mesenteric arteries assaciated with malabsorption; a report of two cases successfully treated by thromboendarterectomy. N Engl J MEd: 1958;258:874-8.

64. Morris $\mathrm{GC}_{3} \mathrm{Jr}$., Crawford ES, Cooley DA. Debakey ME. Revascullarization of the celiac and superior mesenteric arteries. Arch Surg. 1962;84:95-107.

65. Furrer J, Gruntzig A, Kugelmeier $d$, Goebel N. Treatment of abdominal angina with percutaneous dilatation of an arteria mesenterica superior stenosis. Preliminary communication. Cardlovesc intervent Radiol 1980;3:43-4.

66. Westaby S, Cecyl B. Surgery of the thoracic aorta. In: Westaby S, ed Landmarks in Cardiac Surgery. Oxford, UK: Isis Medical Media Ltd; 1997.

67. Schechter DC Bergan JJ. Popliteal aneurysm: a celebration of the bicentennial of John Hunter's operation. Ann Vasc Surg. 1986;1:118-26.

68. Mattas R. Surgery of the vascular system. In: Matas R, ed. Surgery, Its Principles and Practice. Philadelphia: WB Saunders; 1914.

69. Abermethy J. Surgical observations on the constitutional origin and treatment of local diseases, and on aneurysms. 5th ed. London: Longman, Hurst, Rees, Orme; 1820. 
70. Cooper A. Lectures on the principles and practice of surgery. As delivered in the theatre of $S$. Thomas's Hospital. London, UK: F.C. Westley: 1830.

71. Moore $C$. On a new method of procuring the consolidation of fibrin in certain incurable aneurysms. Med Chir Trans (London). 1864;47:129-30.

72. Harrison $P$, Chandy J. A subclavian aneurysm cured by cellophane fibrasis. Ann Surg. $1943 ; 118: 478-80$.

73. Gurey LE, Swan KG, Jr., Swan KG. James Hogarth Pringle, J Trauma. 2005;58:201-5.

74. Matas R. Endo-aneurismorrhaphy. Surg Gynecol Obstet. 1920;30:456-8.

75. Dubost $C$, Allary $M_{t}$ Oeconomos $N$. Resection of an anelurysm of the abdominal aorta: reestablishment of the continuity by a preserved human arterial graft, with result after five months. AMA Arch Surg. 1952;64:405-8.

76. Parodi $J C$, Palmaz JC, Barone HD. Transfemoral intraluminal graft implantation for abdominal aortic aneurysms. Ann Vasc Surg. 1991;5:491-9.

77. Volodos NL, Shekhanin VE, Karpovich IP, Troian VI, Gur'ev lu A. [A self-fixing synthetic blood vessel endoprosthesis]. Vesth Khir /m // Grek. 1986;137:123-5.

78. Greenhalgh RM, Brown LC, Kwong GP. Powell JT, Thompson SG. Comparison of endovascular aneurysm repair with open repair in patients with abdominal aortic aneurysm (EVAR trial 1), 30-day operative mortality results: randomised controlied trial. Lancet. 2004;364:843-8.

79. Peppelenbosch $N$, Yilmaz $\mathbb{N}$, van Marrewijk $C$, Buth J, Cuypers P, Duijm L, Tielbeek A. Emergency treatment of acute symptomatic or ruptured abdominal aortic aneurysm. Outcome of a prospective intent-to-treat by EVAR protocol. Eur \& Vasc Endovasc Surg. 2003:26: 303-10.

80. Murray CJ, Lopez AD. Mortality by cause for eight regions of the world: Global Burden of Disease Study. Lancet. 1997;349:1269-76.

81. Beaglehole $\mathbb{R}$, Irwin A, Prentice $T$. The World Helth Report 2003 - shaping the future. In. Geneva, Switzerland: World Health Organization; 2003.

82. Unal $B$, Critchley JA, Fidan $D$, Capewell $S$. Life-years gained from modern cardialogical treatments and population risk factor changes in England and Wales, 1981-2000. Am J Public Health 2005;95:103-8.

83. Tunstall-Pedoe $H$, Kuulasmaa $K$, Mahonen $M$, Tolonen $H$, Ruokokoski $E_{\text {n }}$ Amouyel $P$. Contribution of trends in survival and coronary-event rates to changes in coronary heart disease mortality: 10-year results from 37 WHO MONICA project populations. Monitoring trends and determinants in cardiovascular disease. Lancet. 1999;353:1547-57.

84. CBS. 1899-1994. Vijfennegintig jaren statistiek in tijdsroeksen. "s Gravenhage: Staatsuitgeverij; 1994.

85. Koek HL, Grobbee DE, Bots ML. ITrends in cerdiovascular morbidity and mortallity in the Netherlands, 1980-2000]. Ned Tijdschr Geneeskd. 2004;148:27-32.

86. American Heart Association. Heart Disease and Stroke Statistics - 2005 Update. In. Dallas, Texas: American Heart Association; 2005.

87. Kannel WB, Dawber TR, Kagan $A_{n}$ Revotskie $N$, Stokes J, 3rd. Factors of risk in the development of coronary heart disease-six year follow-up experience. The Framingham Study. Ann Intern Med. 1961:55:33-50.

88. Keys A. A Murtivariate Analysis of Death and Coronary Heart Disease. Cambridige, Mass: Harvard University Press; 1980.

89. Kannel WB, Shurtleff $D$. The Framingham Study. Cigarettes and the development of intermittent claudication. Geriatrics. 1973;28:61-8.

90. Doyle JT, Dawber TR, Kannel WB, Hesim AS, Kahn HA. Cigarette smoking and coronary heart disease. Combined experience of the Albany and Framingham studies. Nord Hyg Tidskr. 1962;26:796-801.

91. Kannel WB, Castelli WP, Gordon T, McNamara PM. Serum cholesterol, lipoproteins, and the risk of coronary heart disease. The Framingham study. Ann Infern Med. 1971; $74: 1-12$.

92. Gordon T, Castelli WP, Hjortland MC Kannel WB, Dawber TR. High density lipoprotein as a protective factor against coronary heart disease. The Framingham Study. Am I Med. 1977;62:707-14. 
93. Kannel WB, Dawber TR, McGee DL. Perspectives on systollic typertension. The Framingham study. Circulation. 1980,61:1179-82.

94. Kannel WB. McGee DL. Dilabetes and cardiovascular risk factors: the Framingham study. Circulation. 1979;59:8-13.

95. Gordon T, Castelli WP. Hortland MC, Kannel WB, Dawber TR. Predicting coronary heart disease in middle aged and older persons. The Framington study. JAMA, 1977:238:497-9.

96. Prewertion of coronary heart disease in clinicial practice. Recommendations of the Second Joint Task Force of European and other Societies on coronary prevention. Eur Heant 4 . $1998 ; 19: 1434-503$

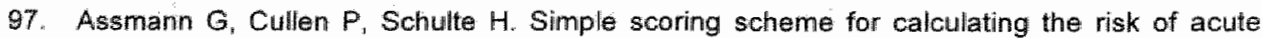
coroniary events based on the 10-year follow-up of the prospective caardiovascular Muryster (PROCAlv) study. Circulation. 2002;105:310-5.

98. Tunstall-Pedoe $H$. The Dundee coronary risk-disk for management of change in risk factors BMU. 1991;303:744-7.

99. Wilson PW, D'Agostino RB, Levy D, Belanger AM, Silbershatz $H_{*}$ Kannel WB. Prediction af coronary heart disease using risk factor categories. Circulation. 1998,97:1837-47.

100. Austini MA. Plastma triglyceride and coronary heart disease. Arterioscter Thromb. 1991,11: 2-14.

101. Schaefer EJ "Lamon-Fava S, Jenner JL, McNamara JR, Ordovas JM, Davis CE, Abolafia JM, Lippel K, Lewy Rl. Lipoprotein(a) levels and risk af coronary heart disease in men. The lipid Research Clinics Coronary Primary Prewention Trial. JAMA 1994:271:999-1003.

102. Genest JJ, JI. MoNamara JR, Salem DN, Wilson PW, Schaefer EJ, Malinow MR. Plasma homocyst(e)ine levels in men with premature coronary artery disease. 'Am Coll Cardiol 1990:16:1114-9.

103. Myers RH, Kiely DK, Cupples LA, Kannel WB. Parental history is an independent risk factor for coronary artery disease: the Framingham Study. Am Heart $\alpha$. 1990;120;963-9.

104. Thompson SG, Kienast J.Pyke SD, Haverkate $F$, van de Loo JC. Hemostatic factors and the risk of myocardial infarction or sudden death in patients with angina pectoris. European Concerted Action on Thrombosis and Disabilities Angina Pectoris Study Group. $N$ Engl $/$ Med. 1995;332:635-41

105. McGill HC, Jr., McMahan CA, Malcom GT, Oalmann MC, Strong JP. Effects of serum lipoproteins and smoking on atherosclerosis in young men and women. The PDAY Research Group. Pathobiological Determinants of Atherosclerosis in Youth. Arderioscler Thromb Vasc Bio/ 1997:17:95-106

106. Relationship of atherosclerosis in young men to serum lipoprotein cholesterol concentrations. and smoking. A preliminary report from the Pathobiological Determinants of Atherasclerosis in Youth (PDAY) Research Group. JAMA 1990;264:3018-24.

107. Braumwald E. Shatuck lecture-cardiovascular medicine at the turn of the millenmium tritumphs, concerns, and opportunitles. N Engl J Med. 1997:337:1360-9.

108. Futterman $L G$, Lemberg $L$. Fifty percent of patients with coronary artery disease do not have any of the conventional risk factors. Am J Crit Care. 1998;7:240-4

109. Hennekens $\mathrm{CH}$. Increasing burden of cardiovascular disease: current knowledge and future directions for research on risk factors. Cinculation. 1998;97:1095-102.

110. Khot UN, Khot MB, Bajzer CT, Sapp SK, Ohman EM, Brener SJ, Ellis SG, Lincoff AM, Topol EJ. Prevalence of comventional risk factors in patients with coronary heart disease. JAMA.
$2003 ; 290: 898-904$.

111. Greenland P. Knoll MD, Stamiler J, Meaton JD, Dyer AR, Garside DB, Wilson PW. Major risk factors as antecedents of fatal and nonfatal coronary heart disease events. JAMA.
$2003,290,891-7$.

12. Stamler J. Fortmann SP, Levy RI, Prineas RJ. Tell G. Primordial prevention of cardiovasculat disease risk factors: panel summary. Prev Med. 1999:29:S130-5.

113. Ross R. Atherosclerosis- an inflammatory disease. $N$ Engl J Med 1999;340:115-26. 
114. Naghavi M, Libby $P$, Falk E, Casscells SW, Litowsky $S$, Rumberger J, Badimon Ji, Stefanadis C. Moreno P, Pasterkamp G, Fayad Z, Stone PH, Waxman S, Raggi P, Madjid M Zarrabi A, Burke $A$, Yuan $C$, Fitzgerald PJ, Siscovick DS, de Korte CL, Aikawa M, Juhani Airaksinen KE, Assmann G, Becker CR, Chesebro JH, Farb A, Galis ZS, Jackson $C_{i}$ Jang IK, Koenig W, Lodder RA, March K, Demirovic J, Navab M, Priori SG, Rekhter MD, Bahr R, Grundy SM.

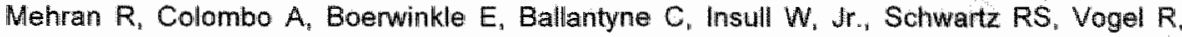
Serruys PW, Hansson GK, Faxon DP, Kaul S, Drexler H, Greenland P, Muller JE, Virmani $R$, Ridker PM, Zipes DP, Shah PK, Willerson JT. From vulnerable plaque to vulnerable patient: a call for new definitions and risk assessment strategies: Part I. Circulation. 2003;108:1664-72.

115. Steinberg $D$. Low density lipoprotein oxidation and its pathobiological significance. $J$ Biof Chem, 1997:272:20963-6.

116. Quinn MT, Parthasarathy $S$, Fong LG, Steinberg D. Oxidatively modified low density lipoproteins: a potential role in recruitment and retention of monocyte/macrophages during atherogenesis. Proc Nat Acad SciU S A. 1987:84:2995-8.

117. Yui $S$, Sasaki $T$, Miyazaki $A$, Horiuchi $S$, Yamazaki $M$. Induction of murine macrophage growth by modified LDLs. Arterioscler Thromb. 1993;13:331-7.

118. Chatterjee $S$, Ghosh N. Oxidized low density lipoprotein stimulates aortic smooth muscie cell proliferation. Glycobiology. 1996;6:303-11.

119. Jonasson L, Holm J, Skalli $O$, Bondjers $G$, Hansson GK. Regional accumulations of $T$ cells, macrophages, and smooth muscle cells in the human atherosclerotic plaque. Arteriosclerosis. $1986 ; 6: 131-8$.

120. Henriksen T, Mahoney EM, Steinberg D. Interactions of plasma lipoproteins with endothelial cells. Ann N Y Acad Sci. 1982;401:102-16.

121. Blake GJ, Ridker PM. Novel clinical markers of vascular wall inflammation. Circ Res 2001;89:763-71.

122. Westhuyzen J, Healy $H$. Review: Biology and relevance of C-reactive protein in cardiovascular and renal disease. Ann Clin Lab Sci. 2000;30:133-43.

123. Pepys MB, Baltz ML. Acute phase proteins with special reference to C-reactive protein and related proteins (pentaxins) and serum amyloid A protein. Aoiv /mmunol. 1983;34:141-212.

124. Rifai N, Tracy RP, Ridker PM. Clinical efficacy of an automated high-sensitivity C-reactive protein assay. Clin Chem. 1999;45:2136-41.

125. Roberts WL, Sedrick $R$, Moulton $L$, Spencer $A$, Rifai $N$. Evaluation of four automated highsensitivity $C$-reactive protein methods: implications for clinical and epidemiological applications. Clin Chem 2000;46:461-8.

126. Rifai N, Buring JE, Lee IM, Manson JE, Ridker PM. Is Cureactive protein specific for wascular disease in women? Ann Intern Med. 2002;136:529-33.

127. De Backer J Mak $R$, De Bacquer $D$, Van Renterghem $L$, Verbraekel $E$, Kornitzer $M$, De Backer $G$. Parameters of inflammation and infection in a community based case-control study of coronary heart disease. Aitherosclerosis. 2002;160:457-63.

128. Abdelmouttaleb I, Danchin $N$, llardo $C_{*}$ Aimone-Gastin I, Angiol M, Lozniewski $A_{\text {, Loubinoux }}$ $\mathrm{J}$, Le Faou A, Gueant JL. C-Reactive protein and coronary artery disease: additional evidence of the implication of an inflammatory process in acute coronary syndromes. Am Heart $\mathcal{U}$. 1999;137:346-51.

129. Anderson JL. Carlquist JF, Muhlestein JB, Harne BD, Elmer SP. Evaluation of C-reactive protein "an inflammatory marker, and infectious serology as risk factors for coronary artery disease and myocardial infarction. IAm Coll Cardio/. 1998;32:35-41.

130. Brevetti $G$, Piscione $F$, Silvestro $A$, Galasso G, Di Donato A, Oliva G, Scopacasa $F$, Chiariello $M$. Increased inflammatory status and higher prevalence of three-vessel coronary artery disease in patients with concomitant coronary and peripheral atherosclerosis. Thromb Haemost. 2003;89:1058-63.

131. Erren $M$, Reinecke $H$, Junker $\mathbb{R}_{*}$ Fobker $M_{*}$ Sichulte $H$, Schurek Jo, Kropf J, Kerber $S_{*}$ Breithardt $G$, Assmann $G$. Cullen $P$. Systemic inflammatory parameters in patients with atherasclerosis of the coronary and peripheral arteries. Artertoscler Thromb VasC Biof. $1999: 19: 2355-63$. 
132. Rifial N, Joubran $R$, Yu $H$, Asmi $M$, Jouma $M$. Inflammatory markers in men with angiographically documented coronary heart disease. Chin Chem. 1999:45:1967-73.

133. Ikonomidis I. Andreotti $F_{*}$ Economou $E$, Stefanadis $C$, Toutouzas $P$. Nhoyannopoulos $P$. Increased proinflammatory cytokines in patients with chronic stable angina and their reduction by aspirin. Circulation. 1999;100:793-8.

134. Toss H, Lindahil $B$, Slegibahn $A$, Wallentin $L$. Prognostic influence of increased fibrinogien and C-reactive protein levels in unstable coronary artery disease. FRISC Study Group. Fragmin during Instability in Coronary Artery Disease. Circulation. 1997:96:4204-10.

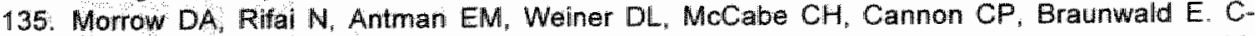
reactive protein is a patent predictor of mortality independently of and in combination with troponin $T$ in acute coronary syndromes: a TIMI 11A substudy. Thrombolysis in Myocardial infarction. J Am Coll Cardiol. 1998;31:1460-5.

136. Lindahl $B$, Toss $H$, Siegbahn $A$, Venge $P$, Wallentin $L$. Markers of myocardial damage and inflammation in relation to long-term mortality in unstable cononary artery disease. FRISC Study Group. Fragmin during Instability in Coronary Artery Disease. $N$ Engl I Med. 2000;343:1139-47

137. Liuzzo $G$, Biasucci $L M$, Gallimore JR, Grillo RL, Rebuzzi $A G$, Pepys MB, Maseri $A$. The prognostic value of $\mathrm{C}$-reactive protein and serum amyloid a protein in severe unstable angina. N Engl J Med: 1994;331:417-24

138. Haverkate F. Thompson SG, Pyke SD, Gallimore JR, Pepys MB. Production of Cureactive protein and risk of coronary events in stable and unstable angina. European Concerted Action on Thrombosis and Disabilities Angina Pectoris Study Group. Lancet. 1997;349:462-6.

139. Biasucci $L M$, Liuzzo $G$, Grillo RL, Caligiuri $G$, Rebuzzi $A G$, Buffon $A$, Summaria $F$, Ginnetti $F$, Fadda G, Maseri A. Elevated Levels of C-Reactive Protein at Discharge in Patients With Unstable Angina Predict Recurrent Instability. Circulation. 1999;99:855-60.

140. Ferreiros $E R$, Boissonnet $C P$, Pizarro $R$, Merletti PF, Corrado $G$, Cagide $A$, Bazzino $O 0$. Independent prognostic walue of elevated C-reactive protein in unstable angina. Circulation. 1999;100:1958-63.

141. Milazzo D, Biasucci LM, Luciani N, Martinelli L, Canosa C, Schiavello R, Maseri A, Possati G Elevated levels of C-reactive protein before coronary artery bypass grafting predict recurrence of ischemic events. Am al Cardiol, 1999:84:459-61, A9.

142. Buffon $A, L i u z z o, G$, Blasucci LM, Pasqualetti $P$, Ramazzotti $V$, Rebuzzi $A G$, Crea $F$, Maseri A. Preprocedural serum levels of C-reactive protein predict early complications and late restenosis after coronary angioplasty. $J / A m$ Col/ Cardiol. 1999;34:1512-21.

143. Heeschen $\mathrm{C}$. Hamm CW. Bruemmer J, Simoons ML. Predictive value of $\mathrm{C}$-reactive protein and troponin $T$ in patients with unstable angina: a comparative analysis. CAPTURE Investigators. Chimeric CFE3 AntiPlatelet Therapy in Unstable angina REfractory to standard treatment triel. 4 Am Coll Cardiol. 2000;35:1535-42.

144. Chew DP, Bhatt DL, Robbins MA, Penn MS, Schneider „IP, Lauer MS, Topol EJ, Ellis SG Incremental prognostic value of elevated baseline C-reactive protein among established markers of risk in percutaneous coronary intervention. Circulation. 2001;104:992-7.

145. Rossi $E$, Biasucci LM, Citterio $F$ "Pelliccioni $S$, Monaco $C$, Ginnetti F. Angiolillo DJ, Grieco $G$,

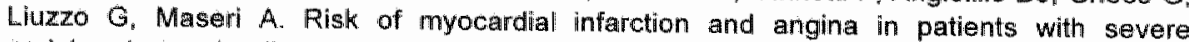
peripheral vascular disease: predictive role of C-reactive protein. Circulation. $2002 ; 105: 800-3$.

146. Kuller LH. Tracy RP , Shaten J, Meillahn EN. Relation of C-reactive protein and coronary heart disease in the MRFIT nested case-control study. Muttiple Risik Factor Intervention Trial. $A m \mathrm{~J}$ Epidemiol 1996:144:537-47.

147. Ridker $P M$, Cushman $M$, Stampfer MJ, Tracy RP, Hennekens $C H$. Inflammation, aspirin, and the risk of cardiovascular disease in apparently healthy men. N Engl IMed. 1997;336:973-9.

148. Tracy RP, Lemaitre RN, Psaty BM, Ives DG, Evans RW, Cushman M Meilahn EN, Kuller LH. Relationship of C-reactive protein to risk of cardiovascular disease in the elderly. Results from the Cardiovascular Health Study and the Rural Health Promotion Project. Arterioscler Thromb Vasc Biol. 1997:17:1121-7. 
149. Koenig $W$, Sund $M_{0}$ Frohlich $M$, Fischer $H G_{\text {, }}$ Lowel $H_{3}$. Doring $A_{4}$ Hutchinson $W_{L}$, Pepys $M B$. C-Reactive protein, a sensitive marker of inflammation, predicts future risk of coronary heart disease in initially healthy middle-aged men: results from the MONICA (Monitoring Trends and Determinants in Cardiovascular Disease) Augsburg Cohort Study, 1984 to 1992. Circulation. 1999:99:237-42.

150. Harris TB, Ferrucci L, Tracy RP. Corti MC, Wacholder $S$, Ettinger WH, Jr., Heimovitz $H_{4}$ Cohen $\mathrm{HJ}$, Wallace $R$. Associations of elevated interleukin-6 and $\mathrm{C}$-reactive protein levels. with mortality in the elderly. Am J Med. 1999;106:506-12.

151. Mendall MA, Strachan DP. Butland BK, Ballam L, Morris $\Downarrow$, Sweetnam PM, Elwood PC. Creactive protein: relation to total mortality, cardiovascular mortality and cardiovascular risk factors in men. Eur Heart $d: 2000 ; 21: 1584-90$.

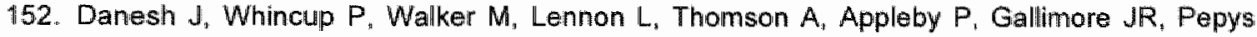
MB. Low grade inflammation and coronary heart disease: prospective study and updated meta-analyses. BMJ. 2000;321:199-204.

153. Roivainen $M$, Viik-Kajander $M$, Palosuo $T$, Toivanen $P$, Leinonen $M$, Saikku $P$, Tenkanen $L_{\text {, }}$

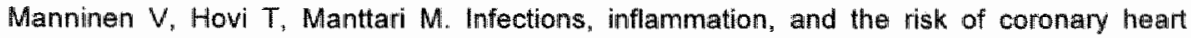
disease. Circulation. 2000;101:252-7.

154. Ridker PM. Hennekens $C H$, Buring JE, Rifai N. C-reactive protein and other markers of inflammation in the prediction of cardiowascular disease in women. $N$ Engl I Med. $2000: 342: 836-43$.

155. Lowe GD, Yamell JW, Rumley A, Bainton D, Sweetnam PM. C-reactive protein, fibrin Ddimer, and incident ischemic heart disease in the Speedwell study: are inflammation and fibrin turnover linked in pathogenesis? Arterioscler Thromb Vasc Biol. 2001;21:603-10.

156. Pradhan AD, Manson JE, Rossouw JE, Siscovick DS, Mouton CP, Rifai N, Wallace RB, Jackson RD, Pettinger MB, Ridker PM. Inflammatory biomarkers, hormone replacement therapy, and incident coronary heart disease: prospective analysis from the Women's Health Initiative observational study. JAMA. 2002;288:980-7.

157. Sakkinen $\mathrm{P}$, Abbott RD, Curb JD, Rodriguez BL, Yano $K_{*}$ Tracy RP. C-reactive protein and myocardial infarction. J Clin Epidemiol. 2002;55:445-51.

158. Gussekloo J, Schaap MC, Frolich M, Blauw GJ, Westendorp RG. C-reactive protein is a strong but nonspecific risk factor of fatal stroke in elderly persons. Arterioscler Thromb Vasc Biol. 2000,20:1047-51.

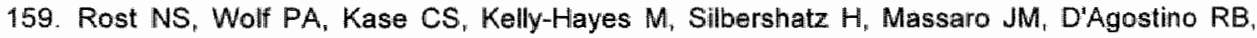
Franzblau C, Wilson PW. Plasma concentration of C-reactive protein and risk of ischemic stroke and transient ischemic attack: the Framingham study. Stroke. 2001;32:2575-9.

160. Ridker PM, Cushman M, Stampfer MJ, Tracy RP. Hennekens $\mathrm{CH}$. Plasma concentration of C-reactive protein and risk of developing peripheral vascular distase. Circulation. 1998;97:425-8.

161. Ridker PM. Clinical application of C.reactive protein for cardiovascular disease detection and prevention. Circulation. 2003:107:363-9.

162. Feldman M, Jialal I, Devaraj S, Cryer B. Effects of low-dose aspirin on serum Cureactive protein and thromboxane B2 concentrations: a placebo-controlled study using a highly sensitive C-reactive protein assay. J Am Coll Cardiol 2001;37:2036-41.

163. Ridker PMn Rifai N, Pfeffer MA , Sacks F, Braunwald $E$. Long-term effects of pravastatin on plasma concentration of C-reactive protein. The Cholesterol and Recurrent Events (CARE) Investigators. Circulation. 1999;100:230-5.

164. Jialal I. Stein D, Balis D, Grundy SM, Adams-Huet B, Devaraj S. Effect of hydroxymethyl glutaryl coenzyme a reductase inhibitor therapy on thigh sensitive C-reactive protein levels. Circulation. 2001:103:1933-5.

165. Albert MA, Danielson $E$, Rifai $N$, Ridker PM. Effect of statin therapy on C-reactive protein levels: the pravastatin inflammation/CRP evaluation (PRINCE): a randomized trial and cohort study. JAMA. 2001;286:64-70.

166. Ridker PM, Rifai $\mathbb{N}_{\mathrm{r}}$ Lowenthal SP. Rapid reduction in C-reactive protein with cerivastatin among 785 patients with primary hypercholesterolemia. Circulation. 2001,103:1191-3. 


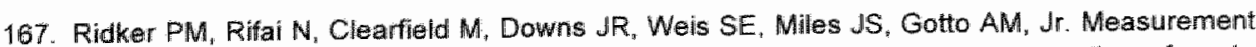
of $C$-reactive protein for the targeting of statin therapy in the primary prevention of acute coronary events. N Engl I Med 2001:344:1959-65.

168. Ridiker PM, Cannon CP, Morrow D, Fifai N, Rase LM, McCabe CH, Pfeffer MA, Braunwald E. C-reactive protein levels and outcomes after statin therapy. N Engl $J / M e d .2005 ; 352: 20-8$.

169. Kushner I, Jiang SL, Zhang D, Lozanski G, Samols D. Do post-transcriptional mechanisms participate in induction of $C$ - reactive protein and serum amyloid $A$ by $\| L-6$ and $I L-1$ ? AnN $N Y$ Acad SCl 1995;762:102-7.

170. Shrive AK, Metcalfe AM; Cartwright JR, Greenhough TJ. C-reactive protein and SAP-like pentraxin are both present in Limulus polyphemus haemolymph: crystal structure of Limulus SAP. J Mol Biol. 1999;290:997-1008.

171. Yasojima K, Schwab C, McGeer EG, McGeer PL. Up-regulated production and activation of the complement system in Alzheimer's disease brain. Am I Pathol. 1999:154:927-36.

172. Yasojima $K$, Schwab $C, M c G e e r ~ E G$, McGeer PL. Human neurons generate $C$-reactive protein and amyloid P: upregulation in Alzheimer's disease. Brain Res. 2000;887:80-9.

173. Yassojima $K$, Schwab $C$. McGeer EG. McGeer PL. Human heart generates complement proteins that are upregulated and activated after myocardial infarction. Circ Res. $1996 ; 83: 860-9$.

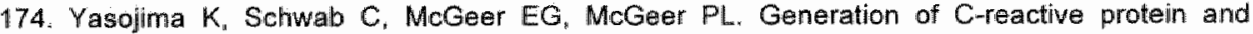
complement components in atherosclerotic plaques. Am J Pathol. 2001:158:1039-51

175. Hatanaka $\mathrm{K}$, Li XA, Masuda $\mathrm{K}$, Yutani $\mathrm{C}$, Yamamoto A. Immunohistochemical lacalization of C-reactive protein-binding sites in human atherosclerotic aortic lesions by a modified streptavidin-biotin-staining method. Patho/ /nt 1995:45:635-41.

176. Torzewski J, Torzewski M, Bowyer DE, Frohlich M, Koenig W, Waltenberger J, Fitzsimmans $C$. Hombach V. C-reactive protein frequently colocalizes with the terminal complement complex in the intima of early atherosclerotic lesions of human coronary arteries. Arterioscler Thromb Vasc Biol 1998;18:1386-92.

177. Torzewski $M$, Rist $C$, Mortensen RF, Zwaka TP, Bienek $M$, Waltenberger $J$, Koenig $W$, Schmitz G, Hombach V. Torzewski J. C-reactive protein in the arterial intima: rolle of $\mathrm{C}$ reactive protein receptor-dependent monocyte recruitment in atherogenesis. Arterioscler Thromb Vasc Biol. 2000;20:2094-9.

178. Cermak J, Key NS, Bach RR, Balla $₫$, Jacob HS, Vercellotti GM. C-reactive protein induces human peripheral blood monocytes to synthesize tissue factor. Blood. 1993:82:513-20.

179. Ballou SP, Lozanski $G$. Induction of inflammatory cytokine release from cultured humam monocytes by C-reactive protein. Cytokine 1992;4:361-8.

180. Verma $S, L i$ SH, Badiwalla MV, Weisel RD, Fedak PW, Li RK, Dhillon B, Mickle DA Endothelin antagonism and interleukin-6 inhibition attenuate the proatherogenic effects of $C$ reactive protein. Chrculation. 2002;105:1890-6.

181. Zwaka TP, Hombach $V$, Torzewski J. C-reactive protein-mediated low density lipoprotein uptake by macrophages: implications for atherosclerosis. Circulation 2001;103:1194-7.

182. Pasceri $V_{n}$ Willerson JT, Yeh ET. Direct proinflammatory effect of $C$-reactive protein on human endothelial cells. Circutation. 2000;102:2165-8.

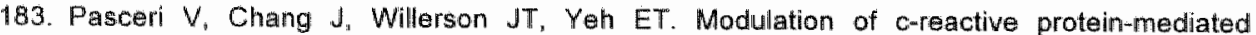
manocyte chemoattractant protein- 1 induction in human endothelial cells by antiatherosclerosis drugs. Circulation. 2001;103:2531-4.

184. Verma S, Wang CH, Li SH, Dumont AS, Fedak PW, Badiwala MV, Dhillon B, Weisel RD, Li RK, Mickle DA, Stewart DJ. A self-fulfilling prophecy: C-reactive protein attenuates nitric oxide production and inhibits angiogenesis. Circulation. 2002;106:913-9.

185. Hattori $Y$, Matsumura $M$, Kasai $K$. Vascular smooth muscle cell activation by $C$-reactive protein. Cardiovasc Res. 2003;58:186-95.

186. Osler W. Diseases of the arteries. In: Osler W, ed. Modern Medicine: Its Practice and Theory. Philadelphia: Lea and Febiger; 1908:429:47

187. Frothingham $C$. The relationship between acute infectious diseases and arterial lesions. Arch Intern Med. 1911;8:153-62. 
188. Ophuls W. Arteriosclerasis and cardiovascular disease: their relation to infectious diseases. JAMA. 1921,76:700-1.

189. Collins S. Excess mortality from causes other than influenza and pneumonia during influenza epidemics. Pub Health Rep. 1932;47:2159-79.

190. Fabricant $C G$, Fabricant J, Litrenta MM, Minick CR. Virus-induced atherosclerosis. I Exp Med 1978;148:335-40.

191. Pesonen $E$, Siitonen $O$. Acute myocardial infarction precipitated by infectious disease. Am Heart J. 1981;101:512-3.

192. Spodick. DH. Flessas AP, Johnson MM. Assaciation of acute respiratory symptoms with onset of acute myocardial infarction: prospective investigation of 150 consecutive patients and matched control patients. Am I Cardiol 1984;53:481-2.

193. Saikku $P$, Leinonen $M$, Mattila $K$, Ekman MR, Nieminen MS, Makela $\mathrm{PH}_{\mathrm{s}}$ Huttunen JK, Valtonen $V$. Serological evidence of an association of a novel Chlamydia, TWAR, with chronic coronary heart disease and acute myocardial infarction. Lancet. 1988;2:983-6.

194. Mattila KJ. Viral and bacterial infections in patients with acute myocardial infarction. I/ intern Med. 1989;225:293-6.

195. Adam E, Melnick JL, Probtsfield JL, Petrie BL, Burek J, Bailey KR, McCollum CH, DeBakey $M E$. High levels of cytomegalovirus antibody in patients requiring vascular surgery for atherasclerasis. Lancet. 1987;2:291-3.

196. Rupprecht HJ, Blankenberg $S$, Bickel $C$, Rippin $G$, Hafner G, Prellwitz W, Schlumberger W, Meyer J. Impact of viral and bacterial infectious burden on long-term prognosis in patients with coronary artery disease. Circulation. 2001;104:25 31.

197. Mendall MA, Goggin PM, Molineaux N, Levy J. Toosy T, Strachan D, Camm AJ, Northfield TC. Relation of Helicobacter pylori infection and coronary heart disease. Br Heart $\mathrm{J}$. 1994:74:437-9.

198. Danesh J, Youngman L, Clark S, Parish S, Peto R, Collins R. Helicobacter pylori infection and early onset myocardial infarction: case-control and sibling pairs study. BMJ. 1999;319:11157-62.

199. Loesche WJ, Schork A, Terpenning MS, Chen YM, Dominguez BL, Grossman N. Assessing the relationship between dental disease and coronary heart disease in elderly U.S. veterans. J Am Dent Assoc. 1998;129:301-11.

200. Haraszthy $V /$, Zambon JJ, Trevisan $M$, Zeid $M$, Genco RJ. Identification of periodontal pathogens in atheromatous plaques. I Periodontol 2000;71:1554-60.

201. Zhu J. Quyyumi AA, Norman JE, Costello R, Csako G, Epstein SE. The possible role of hepatitis $A$ virus in the pathogenesis of atherosclerosis. I Infect Dis. 2000;182:1583-7.

202. Bainton D, Jones GR, Hole D. Inluenza and ischaemic heart disease-a possible trigger for acute myocardial infarction? Int J Epidemiol. 1978:7:23\%.9.

203. Glezen WP. Payne AA. Snyder DN, Downs TD. Mortality and influenza. I Ifrect Dis. 1982:146:313-21

204. Tillett HE, Smith JW, Gooch CD. Excess deaths attributable to influenza in England and Wales: age at death and certified cause. Int $J$ Epiderniol. 1983;12:344-52.

205. Lau RC. Coxsackie B virus-specific IgM responses in coronary care unit patients. M/Med Virol. 1986;18:193-8.

206. Grayston UT, Kuo CC. Campbell LA, Benditt EP. Chlamydia pneumoniae, straim TWAR and atherosclerosis. Eur Heart J. 1993:14 Suppl K:66-71.

207. Gupta S. Leatham EW, Carrington D, Mendall MA, Kaski JC, Camm AJ. Elewated Chlamydia pneumoniae antibodies, cardiovascular events, and azithromycin in male survivors of myocardial infarction. Circulation. 1997;96:404-7.

208. Gurfinikel $E$, Bozovich $G$, Daroca $A$, Beck $E$, Mautner $B$. Randomised trial of roxithromycin in non-Q-wave coronary syndromes: ROXIS Pilot Study. ROXIS Study Group. Lancet. 1997;350:404-7.

209. Grayston JT, Wang SP. History of Chlamydia pneumoniae (TWAR), In: Allegra L, Blasi F. eds. Chlamydia pneumoniae: the lung and heart. Milan: Springer; 1999:1-8.

210. Grayston $ل \mathrm{~T}$, Kuo $\mathrm{CC}$, Wang SP, Altman J. A new Chlamydia psittaci strain, TWAR, isolated in acute respiratory tract infections. $N$ Eng/ J Med. 1986;315:161-8. 
211. Grayston JT, C. KO, Campbell LA, Wang SP. Chlamydia pneumoniae sp. nov. for Chlamydia sp. strain TWAR. Int J Syst Bacteriot 1989;39:88-90.

212. Ward ME. The chlamydial developmental cycle. In: Baron AL, ed. Microbiology of chlamydiae. Boca Raton, Fla: CRC Press Inc; 1988.

213. Beatty WL, Morrison RP. Byrne Gl. Persistent chlamydiae: from cell culture to a paradigm for chlamydial pathogenesis. Microbiol Riev. 1994;58:686-99.

214. Grayston JT, Aldous MB, Easton $A$, Wang SP, Kuo CC, Campbell LA, Altman J. Evidence that Chlamydia pneumoniae causes pneumonia and bronchitis. I Infect Dis. 1993;168: $1231-5$.

215. Fang GD, Fine $M$, Orloff $J$, Arisumi D, Yu VL, Kapoor W, Grayston JT, Wang SP, Kohler R, Muder $\mathrm{RR}_{n}$ et al. New and emerging etiologies for community-acquired pneumonia with implications for therapy. A prospective multicenter study of 359 cases. Medicine (Baltimore). 1990;69:307-16.

216. Gaydos $C A_{4}$ Eiden $J J$, Oldach D, Mundy LM, Auwaerter $P$, Warner ML, Vance E, Burton AA, Quinn TC. Diagnasis of Chlamydia preumoniae infection in patients with community-acquired pneumonia by polymerase chain reaction enzyme immunoassay. Clin Infect Dis. 1994;19:157-60.

217. Kauppinen MT, Herva $E$, Kujala $P$, Leinonen $M$, Saikku $P$, Syrjala $H$. The etiology of community-acquired pneumonia among hospitalized patients during a Chlamydia pneumoniae epidemic in Finland. J/nfect Dis. 1995;172:1330-5.

218. Lieberman $D$, Ben-Yaakov $M$. Lazarovich $Z$, Porath $A$, Schlaeffer $F$, Leinonen $M$, Saikku $P$, Horovitz $O$. Bolldur I. Chlamydia pneumoniae community-acquired pneumonia: a review of 62 hospitalized adult patients. Infection. 1996;24:109-14.

219. Wang SP, Grayston JT. Population prevbalence of antibody to Chlamydia pneumoniae, strain TWAR. In: Bowie WR, Caldwell HD, Jones RP, Mardh PA, Ridgway GL, Schachter J, eds. Chlamydial Infections. Cambridge, UK: Cambridge University Press; 1990:402-5.

220. Kleemola M, Saikku P, Visakorpi R, Wang SP, Grayston JT. Epidemics of pneumonia caused by TWAR, a new Chlamydia organism, in military trainees in Finland. I Infect Dis. 1988;157:230-6.

221. Aldous MB, Wang SP, Foy HM, Grayston JT. Chlamydia pneumoniae, strain TWAR, infection in Seattle children and their famillies, 1965-79. Im: Bowie WR, Caldwell HD, Jones RP, Mardh

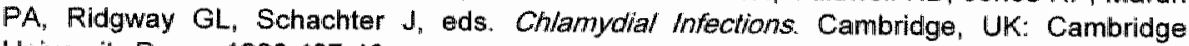
University Press; 1990:437-40.

222. Aldous MB, Grayston JT, Wang SP, Foy HM. Seroepidemiology of Chlamydlia pneumoniae TWAR infection in Seattle families, 1966-1979. J Infect Dis. 1992;166:646-9.

223. May J. La intradermoreaccion de Frei en las arteriopatias. Revista Argentina Dermatosiffils. $1943 ; 27: 581-2$

224. Quiroga $M_{1}$ Anbrosetti $F E$. La reaccion de Freil en las endoarteritis obliterantes. Revista Argentina Dermatosifilis. 1943;27:624-5.

225. Coutts WE, Davilla M. Lymphogranulama venereum as a possible cause of arteriosclerosis and other arterial conditions. I Trop Med Hyg. $1945 ; 48: 46-51$.

226. Campbell LA, Kuo CO. Chlamydia pneumoniae--an infectious risk factor for atherosclerosis? Nat Rev Microbiol. 2004:2:23-32.

227. Danesh $J$ whincup $P$, Walker $M$, Lennon $L$, Thomson A. Appleby $P$, Wong $Y$, Bernardes Silva M. Ward M. Chlamydia pneumoniae IgG titres and coronary heart disease: prospective study and meta-analysis. $B M J 2000 ; 321: 208-13$.

228. Danesh $J_{\text {"Collins }} R$, Peto $R$. Chronic infections and coronary heart disease: is there a link? Lancet 1997;350:430-6.

229. Grayston JT. Does Chlamydia pneumoniae cause atherosclerosis? Arch Surg. 1999;134: 930-4.

230. Kuo $\mathrm{CC}_{n}$ Campbell LA. Chlamydial infections of the cardiovascular system. Front BiosCi 2003;8:e36-43.

231. Bloemenkamp DG, Mali WP, Visseren FL, van der Graaf $Y$. Meta-analysis of seroepidemiologic studies of the relation between Chlamydia pneumoniae and atherosclerosis: does study design influence results? Am Heart J. 2003;1.45:409-17. 
232. Dowell SF, Peeling RW, Boman J, Carlone GM, Fields BS, Guamer J, Hammerschlag MR, Jackson LA, Kuo $C C$, Maass $M_{*}$ Messmer TO, Talkington DF, Tondella ML, Zaki SR. Standardizing Chlamydia pneumoniae assays: recommendations from the Centers for Disease Control and Prevention (USA) and the Laboratory Centre for Disease Control (Canada). Clin Intect Dis. 2001:33:492-503.

233. Leinonen $M$. Saikku $P$. Evidence for infectious agents in cardiovascular disease and atherosclerosis. Lancet infect Dis. 2002;2:11-7.

234. Ong G. Thomas BJ, Mansfield AO, Davidson BR, Taylor-Robinson D. Detection and widespread distribution of Chlamydia pneumoniae in the vascular system and its possible implications. J Clin Pathol. 1996;49:102-6.

235. Campbell LA, Kuo CC. Grayston JT. Chlamydia pneumoniae and cardiovascular disease. Emerg Infect Dis. 1998;4:571-9.

236. Apfalter $P$, Blasi $F$, Boman $J$, Gaydos $C A$, Kundi $M$, Maass $M$, Makristathis $A$, Meijer $A_{\text {, }}$ Nadrchal R, Persson K, Rotter ML, Tong CY, Stanek G, Hirschl AM. Multicenter Comparison Trial of DNA Extraction Methods and PCR Assays for Detection of Chlamydia pneumoniae in Endarterectomy Specimens. J Clin Microbiol. 2001;39:519-24.

237. Boman J, Hammerschlag MR. Chlamydia pneumoniae and Atherosclerosis: Critical Assessment of Diagnostic Methods and Relevance to Treatment Studies. Clin Microbiol Rev. 2002;15:1-20.

238. Thomas $M$, Wang $Y$, Thomas $D$, Ajaz M, Tsang $V$, Gallagher PJ, Ward ME. Relation between direct detection of Chlamydia pneumoniae DNA in human coronary arteries at postmortem examination and histologicall severity (Stary grading) of associated atherosclerotic plaque. Circulation. 1999;99:2733-6.

239. Ericson $K_{n}$ Saldeen TGP, Lindquist $O$, Pahlson $C$, Mehta JL. Relationship of Chlamydia pneumoniae Infection to Severity of Human Coronary Atherosclerosis. Circulation. 2000;101:2568-2571.

240. Gaydos CA, Summersgill JT, Sahney NN, Ramirez JA, Quinn TC. Replication of Chlamydia pneumoniae in vitro in human macrophages, endothelial cells, and aortic artery smooth muscle cells. Infect Immun. 1996;64:16:14-20.

241. Moazed TC, Kuo C, Grayston JT, Campbell LA. Murine models of Chlamydia pneumoniae infection and atherosclerosis. J/nfect Dis. 1997:175:883-90.

242. Rupp J, Koch $M$, vanZandbergen $G$, Solbach $W$, Brandt $E$, Maass $M$. Transmission of Chlamydia pneumoniae infection from blood monocytes to vascular cells in a novel transendothelial migration model. FEMS Microbiol Lett. 2005;242:203-8.

243. Kalayoglu MV. Perkins BN, Byrne Gil. Chlamydia pneumoniae-infected monocytes exhibit increased adherence to human aortic endothelial cells. Microbes Inrect. 2001;3:963-9.

244. Gaydos CA. Growth in vascular cells and cytokine production by Chlamydia pneumoniae. I Infect Dis. 2000;181 Suppl 3:5473-8

245. Kalayoglu MN, Byrne GI. Induction of macrophage foam cell formation by Chlamydia pneumaniae. J Infect Dis. 1998:177:725-9.

246. Kalayoglu MV, Byrne GI. A Chlamydia pneumoniae component that induces macrophage foam cell formation is chlamydial lipopolysaccharide. Infect /mmun. 1998;66:5067-72.

247. Kalayoglu MV, Hoerneman B, LaVerda D, Morrison SG, Morrison RP, Byrne GI. Cellular oxidation of low-density lipoprotein by Chlamydia pneumoniae. J Infect Dis. $1999 ; 180: 780-90$.

248. Kalayoglu MV, Indrawati, Morrison RP, Morrison SG, Yuan Y, Byrne GI. Chlarnydial virulence determinants in atherogenesis: the role of chlamydial lipopolysaccharicle and heat shock protein 60 in macrophage-lipoprotein interactions. J/nfect Dis: 2000;181 Suppl 3:8483-9.

249. Kaukoranta-Tolvanen SS, Teppo AM, Laitinen $K_{n}$ Saikku $P$, Linnavuori $K$, Leinonen $M$. Growth of Chlamydia pneumoniae in cultured human peripheral blood mononuclear cellls and induction of a cytokine response. Microb Pathog. 1996:21:215-21.

250. Netea MG, Selzman CH, Kullberg BJ, Galama JM, Weinberg A, Stalenhoef AF, Van der Meer JW, Dinarello CA. Acellular companents of Chlamydia pneumoniae stimulate cytokine production in human bload mononuclear cells. Eur $J /$ mmumol 2000;30:541-9. 
251. Kol $A_{i}$ Sukhova $G K_{i}$ Lichtman $A H_{\text {; }}$ Libby $P$. Chlamydial heat shock protein 60 localizes in human atheroma and regulates macrophage tumor necrosis factor-alpha and matrix metalloproteinase expression. Circulation. 1998;98:300-7.

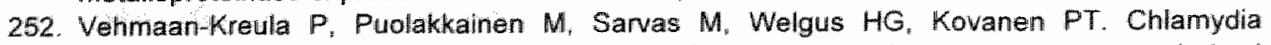
pneumoniae proteins induce secretion of the 92-kDa gelatinase by human monocyte-derived macrophages. Arterioscter Thromb Vasc Biol. 2001;21:E1-8.

253. Coombes BK. Mahony JB. CDNA array analysis of altered gene expression in human endothelial cells in response to Chlamydia pneumoniae infection. Infect Immun. 2001;69:1420-7.

254. Shi $Y$, Tokunaga $O$. Chlamydia pneumoniae (C. pneumoniae) infection upregulates atherosclerosis-related gene expression in human umbilical vein endothelial cells (HUVECs). Atherosclerosis. 2004;177:245-53.

255. Kaukoranta-Tolvanen $S S$, Ronni $T$, Leinonen $M_{2}$ Saikku $P$, Laitinen $K$. Expression of adhesion molecules on endothelial cells stimulated by Chlamydia pneumoniae. Microb Pathog. 1996:21:407-11.

256. Liuba P, Karnani P, Pesonen E, Paakkari II, Forslid $A$, Johansson L, Persson $K$, Wadstrom $T$, Laurini $R$. Endothelial dysfunction after repeated Chlamydia pneumoniae infection in apolipoprotein E-knockout mice. Circulation. 2000;102:1039-44.

257. Molestina RE, Miller RD, Ramirez JA, Summersgill JT. Infection of human endothelial cells with Chlamydia pneumoniae stimulates transendothelial migration of neutrophils and monocytes. Infect /mmun: 1999:67:1323-30.

258. Fryer RH, Schwobe EP, Woods ML, Rodgers GM. Chlamydia species infect human vascular endothelial cells and induce procoagulant activity. J Irvesilg Med. 1997;45:168-74.

259. Dechend R, Maass M, Gieffers J Dietz R. Scheidereit C, Leutz A. Gulba DC. Chlamydia pneumoniae infection of vascular smooth muscle and endothelial cells activates NF-kappaB and induces tissue factor and PAI- $\uparrow$ expression : A potential link to accelerated arteriosclerosis. Circulation. 1999;100:1369-73.

260. Summersgill JT, Molestina RE, Miller RD, Ramirez JA. Interactions af Chlamydia pneumoniae with human endothelial cells. J Infoct Dis. 2000;181 Supp| 3:S479-82

261. Coombers BK, Mahony JB. Chlamydia pneumoniae infection of human endothellal cells induces proliferation of smooth muscle cells via an endothelial cell-derived soluble factor(s). Infect Immun. 1999;67:2909-15.

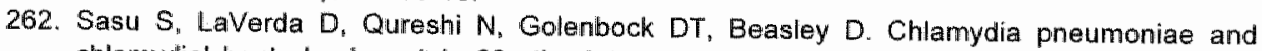
chlamydial heat shock protein 60 stimulate proliferation of human vascular smooth muscle cells via toll-like receptor 4 and $\mathrm{p} 44 / \mathrm{p} 42$ mitogen-activated protein kinase activation. Circ Res. $2001 ; 89: 244 \sim 50$.

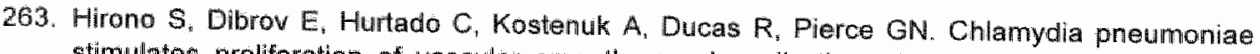
stimulates proliferation of vascular smooth muscle cells through induction of endogenous heat shock protein 60. Circ Res. 2003;93:710-6.

264. Fan $T, L u H, H u H$, Shi L, McClarty GA, Nance DM, Greenberg AH, Zhong G, Inhibition of apoptosis in chlamydia-infected cells: blockade of mitochondrial cytochrome $\mathrm{c}$ release and caispase activation. J Exp Med. 1998;187:487-96.

265. Miller SA, Selzman CH, Shames BD, Barton HA, Johnson SM, Harken AH. Chlamydia pneumoniae activates nuclear factor kappaB and activator protein 1 in human vascular smooth muscle and induces cellular proliferation. J Surg Res. 2000;90:76-81.

266. Rodel J, Prochnau D, Prager K, Pentcheva $E$, Hartmann M, Straube E. Increased production of matrix metalloproteinases 1 and 3 by smooth muscle cells upon infection with Chlamydia pneumoniae. FEMS Immunoi Med Microbiol. 2003;38:159-64. 267. Fong $W$, Chiu $B$, Virra $\mathbb{E}$. Fong MW, Jang $D$, Mahony $J$. Rabbit model for Chlamydia
pneumoniae infection. $J$ Clin Microbiol $1997 ; 35: 48-52$.

268. Muhlestein JB, Anderson JL, Hammond EH, Zhao L, Trehan S, Schwobe EP, Carlquist JF. Infection with Chlamydia pneumoniae accelerates the development of atherosclerosis and treatment with azithromycin prevents it in a rabbit model. Circulation. 1998;97:633-6. 
269. de Kruif MD, van Gorp EC, Keller TT, Ossewaarde JM, ten Cate H. Chlamydia pneumoniae infections in mouse modells: relevance for atherosclerosis research. Cardiovasc Res. 2005;65:317-27.

270. Herrera $V L$, Shen L, Lopez LV, Didishvili $T$ : Zhang $Y X$, Ruiz-Opazo $N$. Chlamydia pneumoniae accelerates coronary artery disease progression in transgenic hyperlipidemiagenetic hypertension rat model. Mol Med. 2003:9:135-42.

271. Pislaru SV, Van Ranst M, Pislaru C, Szelid Z, Theilmeier G, Ossewaarde JM, Holwoet P. Janssens $S$, Verbeken $E$, Van de Werf FJ. Chlamydia pneumoniae induces neointima formation in coronary arteries of normal pigs. Cardiovasc Res. 2003;57:834-42.

272. Aalto-Setala $K$, Laitinen $K$, Erkkila $L$, Leinonen $M$, Jauhiainen $M$, Ehnholm $C$, Tamminen M, Puolakkainen M. Penttilla I, Saikku $P$. Chlamydia pneumoniae does not increase atherosclerosis in the aartic root of apolipoprotein E-deficient mice. Arterioscler Thromb Vasc Biol 2001;21:578-84.

273. Caligiuri $G$, Rottenberg $M$, Nicoletti $A$, Wigzell $H_{1}$ Hansson $G K$. Chlamydia pneumoniae infection does not induce or modify atherosclerosis in mice. Circulation. 2001;103:2834-8.

274. Moazed TC, Kuo CC, Grayston IT, Campbell LA. Evidence of systemic dissemination of Chlamydia pneumoniae via macrophages in the mouse. J infect Dis. 1998:177:1322-5.

275. Moazed TC, Campbell LA, Rosenfeld ME, Grayston JT, Kuo CC. Chlamydia pneumoniae infection accelerates the progression of atherosclerosis in apolipoprotein E-deficient mice. $J$ Infect Dis. $1999 ; 180: 238-41$.

276. Hu $H$, Pierce $G N$, Zhong $G$. The atherogenic effects of chlamydia are dependent on serum cholesterol and specific to Chlamydia pneumoniae. I Clin Invest. 1999;103:747-53.

277. Laitinen $K$, Laurila $A$. Pyhala $L$, Leinonen $M$, Saikku P. Chlamydia pneumoniae infection induces inflammatory changes in the aortas of rabbits. Infect Immur. 1997;65:4832-5.

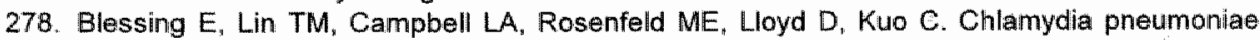
induces inflammatory changes in the heart and aorta of normocholesterolemic C57BL/6J mice. Infect Immun. 2000;68:4765-8.

279. Ezzahiri R, Nelissen-Vrancken HJ, Kurvers HA, Stassen FR, Vliegen I, Grauls GE, van Pul MM, Kitslaar PJ, Bruggeman CA. Chlamydophila pneumoniae (Chlamydia pneumoniae) accelerates the formation of complex atherosclerotic lesions in Apo E3-Leiden mice. Cardiovasc Res. 2002;56:269-76.

280. Ezzahiri R, Stassen FR, Kurvers $H A$, van Pul MM, Kitslaar PJ, Bruggeman CA, Chlamydia pneumoniae infection induces an unstable atherosclerotic plaque phenotype in LDL-receptor, ApoE double knockout mice. Eur I Vasc Endovasc Surg. 2003;26:88-95.

281. Liuba $P_{\text {. }}$ Pesonen $E_{n}$ Paakkari I, Batra $S_{n}$ Forslid $A_{*}$ Kovanen $P$, Pentikainen M. Persson $K_{\text {, }}$ Sandstrom S. Acute Chlamydia pneumoniae infection caulses coronary endothelial dysfunction in pigs. Atherosclerosis. 2003:167:215-22.

282. Fong IW. Antibiotics effects in a rabbit model of Chlamydia pneumoniaeminduced atherosclerosis. Infect Dis. 2000;181 Suppl 3:S514-8.

283. Meier CR, Derby LE, Jick SS, Vasillakis $C$ Jick $H$. Antibiotics and risk of subsequent first-time acute myocardial infarction. JAMA. 1999;281:427-31.

284. Herings RM, Leufiens $H G$, Vandenbroucke JP. Acute myocardial infarction and prior antibiotic use. JAMA. 2000;284:2998-9.

285. Ostergaard L, Sorensen HT, Lindholt J, Sorensen TE, Pedersen L, Eriksen T, Andersen PL. Risk of hospitalization for cardiovascular disease after use of macrolides and penicillins: a comparative prospective cohort study. J Infect Dis. 2001:183:1625-30.

286. Pillote L, Green L Joseph L, Richard H, Eisenberg MJ. Antibiotics against Chlamydia pneumoniae and prognasis after acute myocardial infarction. Am Heart d. 2002;143:294-300

287. Jackson LA, Smith NL, Heckbert SR, Grayston JT, Siscovick DS, Psaty BM. Lack of association between first myocardial infarction and past use of erythromycin, tetracycline, or doxycycline. Emerg Infect Dis. 1999:5:281-4.

288. Luchsinger JA, Pablos-Mendez A, Knirsch C, Rabinowitz D, Shea S. Antibiotic use and risk of ischemic stroke in the elderly. Am J/Med. 2001:111:361-6.

289. Luchsinger JA, Pablos-Mendez A, Knirsch C, Rabinowitz, D, Shea S. Relation of antibiotic use to risk of myocardial infarction in the general population. Am J Cardiol. 2002;89:18-21. 
290. Brassard $P$, Bourgault $C$, Brophy $J$, Kezouh $A_{2}$ Suissa $S$. Antibiotics in primary prevention of stroke in the elderly. Stroke. 2003;34:163-6.

291. Brassard P, Bourgault $C$, Brophy J, Kezouh $A$, Rainville $B$, Xhignesse $M$, Suissa $S$. Antibiotics in primary prevention of myocardial infarction among elderly patients with hypertension. Am Heart $\triangle$. 2003; 145:E20.

292. Sinisalo J, Mattila $K$, Nieminen MS, Valtonen $V$, Syrjala M. Sundberg S, Saikku $P$. The effect of prolonged doxycycline therapy on Chlamydia pneumoniae serological markers, coronary heart disease risk factors and forearm basal nitric oxide production. I Antimicrob Chemother. $1998 ; 41: 85-92$.

293. Melissano $G$, Blasi $F$, Esposito $G$, Tarsia $P$. Dordoni $L$, Arosio $C$, Tshomba $Y$, Fagetti $L$, Allegra $L$, Chiesa R. Chlamydia pneumoniae eradication from carotid plaques. Results of an open, randomised treatment study. Eur J Vasc Endowase Surg. 1999:18:355-9.

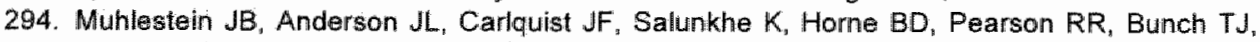
Allen $A_{i}$ Trehan $S$, Nielson $C$. Randomized secondary prevention trial of azithromycin in patients with coronary artery disease: primary clinical results of the AC.ADEMIC study. Circulation. 2000;102:1755-60.

295. Neumann $F$, Kastrati $A_{3}$ Miethke $T$, Pogatsa-Murray $G$, Mehilli $J$, Valina $C$, Jogethaei $N_{\text {, }}$ da Costa CP, Wagner $H$, Schomig A. Treatment of Chlamydia pneumoniae infection with roxithromycin and effect on neointima proliferation after coronary stent placement (ISAR- 3 ): a randomised, double-blind, placebo-controlled trial. Lancet 2001;357:2085-9.

296. Mosorin $M$, Juvonen $J$, Biancari $F$, Satta $J$, Surcel $H M$, Leinonen $M$, Saikku $P$, Juvonen $T$. Use of doxycycline to decrease the growth rate of abdominal aortic aneurysms: A randomized, double-blind, placebo-controlled pilot study. I Vase Surg. 2001;34:606-10.

297. Vammen $S$, Lindholt JS, Osterglaard L, Fasting $H$, Henneberg EW. Randomized double-blind controlled trial of roxithromycin for prevention of abdominal aortic aneurysm expansion. $\mathrm{Br}$ Surg. 2001;88:1066-72.

298. Stone AF, Mendall MA, Kaski JC, Edger TM, Risley P, Poloniecki J, Camm AJ, Northfield TC. Effect of treatment for Chlamydia pneumoniae and Helicobacter pylori on markers of inflammation and cardiac events in patients with acute coronary syndromes: South Thames Trial of Antibiotics in Myocardial Infarction and Unstable Angina (STAMINA). Circulation. 2002;106:1219-23.

299. Sinisalo J, Mattila $K$, Valtonen $V_{n}$ Anttonen $O$, Juvonen J, Melin J, Vuorinen-Markkola $H_{1}$ Nieminen MS. Effect of 3 months of antimicrobial treatment with clarithromycin in acute nonq-wave coronary syndrome. Circulation. 2002:105:1555-60.

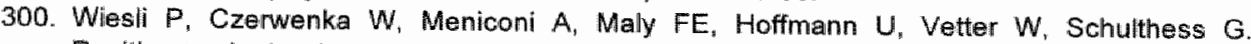
Roxithromycin treatment prevents progression of peripheral arterial occlusive disease in Chlamydia preumoniae seropositive men: a randomized, double-blind, placebo-controlled Irial. Circulation 2002; 105:2646-52

301. Parchure N, Zouridakis EG, Kaski JC. Effect of azithromycin treatment on endothelial function in patients with coronary artery disease and evidence of Chlamydia pneumoniae infection. Circulation. 2002;105:1298-303.

302. Axisa $B_{\text {, Loftus } I M}$ Naylor AR, Goodall S. Jones L, Bell PR, Thompson MM. Prospective, randomized, double-blind trial investigating the effect of doxycycline on matrix metalloproteinase expression within atherosclerotic carotid plaques. Stroke. 2002;33: 2858-64.

303. O'Connor CM, Dunne MW, Pfeffer MA, Muhlestein JB, Yao L, Gupla S, Benner RJ, Fisher $M R$, Cook TD. Azithromycin for the secondary prevention of coronary heart disease events: the WIZARD study: a randomized controlled trial. JAMA4. 2003:290:1459-66.

304. Zahn R, Schneider S, Frilling B, Seidl K, Tebbe U, Weber M, Gottwik M, Altmann E, Seidel F, Rox J. Hoffler $U$, Nouhaus $K-L$. Senges $J$, for the Arbeitsgemeinschaft Leitender Kardiologischer Krankenhausarzte (Working Group of Leading Hospital Cardiologists; ALKK). Antibiotic Therapy After Acute Myocardial Infarction: A Prospective Randomized Study.
Circulation. 2003:107:1253-9. 


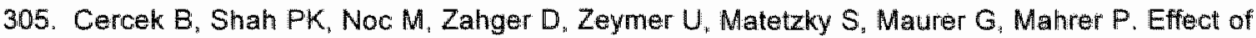
short-term treatment with azithromycin on recurrent ischaemic events in patients with acute coronary syndrome in the Azithromycin in Acute Coronary Syndrome (AZACS) trial: a randomised controlled trial. Lancet. 2003:361:809-13.

306. Sander $D$, Winbeck $K$, Klingelhofer $J$ "Etgen $T$, Conrad B. Progression of early carotid atherosclerosis is only temporarily reduced after antibiotic treatment of Chlamydia pneumoniae seropositivity. Circulation. 2004:109:1010-5.

307. Kuvin JT, Gokce N Holbrook M. Hunter LM, Patel AR, Sliney KA, Graven DE, Grayston JT, Keaney JF, Jr., Karas RH, Vita JA. Effect of short-term antibiotic treatment on Chlamydia pneumoniae and peripheral endothelial function. Am J Cardiol. 2003;91:732-5.

308. Jackson LA. Description and status of the azithromycin and coronary events study (ACES). $J$ Infect Dis. 2000;181 Suppl 3:\$579-81.

309. Sander D, Winbeck $K$, Klingelhofer J. Etgen $T$, Conrad B. Reduced progression of early carotid atherosclerosis after antibiotic treatment and Chlamydia pneumoniae seropositiwity. Circulation. 2002;106:2428-33.

310. Patel $P$, Carrington D, Strachan DP, Leatham $E$, Goggin $P$, Northfield TC, Mendall MA. Fibrinogen: a link between chronic infection and coronary heart disease. Lancet. $1994: 343: 1634-5$.

311. Torgano $G_{\text {, Casentini }} R_{n}$ Mandelli $C$, Perondi $R_{n}$ Blasi $F$, Bertinieri $G_{n}$ Tien TV, Ceriani $G$, Tarsia P. Arosio C, Ranzi ML. Treatment of Helicobacter pylori and Chlamydia pneumoniae infections decreases fibrinogen plasma level in patients with ischemic heart disease. Circulation. 1999;99:1555-9.

312. Mayr M, Metzler B, Kiechl S, Willeit J, Schett G, Xu Q, Wick G. Endothelial cytotoxicity mediated by serum antibodies to heat shock proteins of Escherichia coli and Chlamydia pneumoniae: immune reactions to heat shock proteins as a possible link between infection and atherosclerosis. Circulation. 1999;99:1560-6.

313. Wick $G_{n}$ Knoflach $M, X u Q Q$. Autoimmune and inflammatory mechanisms in atherosclerosis. Annu Rev /mmunol. 2004;22:361-403.

314. Hahn DL, Golubjatnikov R. Smoking is a potential confounder of the Chlamydia pneumoniaecoronary artery disease association. Arterioscler Thromb. 1992;12:945-7.

315. Laurila $A$, Bloigu $A$, Nayha $S$, Hassi J, Leinonen $M$, Saikku $P$, Chronic Chlamydia pneumoniae infection is associated with a serum lipid profile known to be a risk factor for atherosclerosis. Arterioscler Thromb Vasc Biol. 1997;17:2910-3.

316. Grunfeld $C_{n}$ Feingold $K R$. Tumor necrosis factor, interleukin, and interferon induced changes in lipid metabolism as part of host defense. Proc Soc Exp Biol Med.1992;200;224-7.

317. Cook PJ. Lip GY, Daves $P$, Beevers DG, Wise $R$, Honeyboume D. Chlamydia pneumoniae antibodies in severe essential hypertension. Hypertension. 1998,31:589-94.

318. Bokhari SW. Faxon DP. Current advances in the diagnosis and treatment of renal artery stenosis. Rev Cardiovasc Med 2004:5:204-15.

319. Jarvinen $O$, Laurikka J, Sisto T, Salenius JP, Tarkka MR. Atherosclerosis of the visceral arteries. Vasa. 1995;24:9-14.

320. Ouriel K. Peripheral arterial disease. Lancet. 2001;358:1257-64.

321. A comparative study of the prevalence of abdominal aortic aneurysms in the United Kingdom, Denmark ${ }_{\text {, }}$ and Australia. J Med Screen. 2001;8:46-50.

322. Hackam DG, Anand SS. Emerging risk factors for atherosclerotic vascular disease: a critical review of the evidence. JAMA. 2003;290:932-40. 


$$
50
$$




\section{Section 2}

\section{Inflammation \& atherosclerosis}




\section{Chapter 2}

C-reactive protein in peripheral arterial disease:

relation to severity of the disease and to future

cardiovascular events

Vainas T, Stassen FR, de Graaf R, Twiss EL, Herngreen SB, Welten RJ, van den Akker LH, van Dieijen-Visser MP, Bruggeman CA, Kitslaar PJ

J Vasc Surg 2005;42:243-51 


\subsection{Abstract}

\section{Background}

Serum CRP has proven la be an independent marker of the extent of atherosclerosis in patients with coronary, cerebrovascular and peripheral arterial disease. In this prospective observational study we wanted to assess the relationship between serum CRP and extent of disease transversely and longitudinally in time as well as future cardiovascular complications in patients with peripheral arterial disease (PAD). Hypothesizing that CRP not only is a marker of but also actively participates in atherogenesis, we explored the possibility of CRP production by femorall atherosclerotic plaques.

\section{Patients \& methods}

Serum CRP was measured highly sensitive (hSCRP) in 387 patients with PAD attending the vascultar clinic of a universily and two affillated teaching hospitals. Serum hsCRP was related to ankle-birachial pressure index (ABPI), as an indication of severity of disease at inclusion and at 12 months" follow-up and to future events (death, coronary. cerebral, and peripheral arterial events). In femoral plaques, the production of CRP was analyzed with reverse transcription polymerase chain reaction (RT-PCR), and CRP plaque localization was assessed with immunostaining on serial tissue sections with antibodies toward CRP, smooth muscle cells, T-cells and macrophages.

\section{Results}

The hsCRP (average \pm SD) was $3.26 \pm 2.41 \mathrm{mg} /$. Serum hsCRP showed a correlation with baseline and 12-month follow-up ABPI (Spearman rank correlation, $P<0.05$ for both correlations). When the patients were divided into three equally sized groups according to baseline serum hsCRP, the $A B P I$ at baseline and at 12 months decreased significantly from the low to the high hsCRP group (baseline ABPl: $0.70,065$ and $0.57, P e 0.01$; and 12-month follow-Lp $\mathrm{ABPl}: 0.78,0.70$ and 0.65 , P 0.01$)$. These associations persisted after correction for conventionall risk factors. Furthermore, serum hSCRP was related to the combined endpoint 'death and/or any cardiovascular event' (log rank test, $P=0.04$ ) during a median 24-month follow-up period. RT-PCR analysis showed CRP production in 4 of 14 femoral plaques. CRP was defected in all femoral plaques, but not in healthy brachial arteries. Immunoreactivity for CRP was observed in smooth muscle cells, macrophages and T-cells.

\section{Conclusion}

Serum hsCRP was related to severity of PAD, showing a relation to future hemodynamic function and cardiovascular events in PAD patients. In addition to coronary plaques, aneurysmal aortas and failed venous coronary bypasses, femoral plaques as well produce CRP, illustrating that the production of CRP may represent a universal response to vascular injury and suggesting that vascular CRP may contribute to plaque development. 


\subsection{Introduction}

In concord with the inflammatory nature of atherosclerosis, several inflammatory markers, such as, white blood cell count, ${ }^{1}$ erythrocyte sedimentation rate ${ }^{2}$ and $\mathrm{C}$-reactive protein (CRP) have been associated with coronary artery disease. Of these, CRP is the most extensively studied in this regard. It has been shown that serum CRP is increased in patients with coronary artery disease, ${ }^{3}$ whereas in healthy middle-aged and elderly individuals, it is associated with the development of coronary ${ }_{n}^{4.5}$ cerebrat $^{5,6}$ and peripheral vascular events. ${ }^{\text {? }}$

Peripheral arterial disease (PAD) is a common manifestation of atherosclerosis. Its estimated prevalence varies between $0.6 \%$ and $8.8 \%{ }^{8}$ Compared with healthy controls, patients with PAD have increased serum CRP levels. ${ }^{9,10}$ Furthermore, serum CRP seems to be associated with a low anklebrachial pressure index $(\mathrm{ABPl}<0.9)^{10}$, walking performance ${ }^{11}$ and endothelial function in these patients. ${ }^{9}$ Nevertheless, it remains to be seen whether serum CRP is longitudinally related in time to severity of PAD, and whether it is related to future cardiovascular complications in patients with PAD.

The relationship between CRP and the extent of atherosclerosis does not necessarily reflect the systemic nature of a low-grade inflammatory reaction associated with atherosclerosis that leads to stimulated hepatic CRP production. In fact, it has been shown that coronary plaques, aneurysmal aortas and failed venous bypass grafts produce CRP. ${ }^{12-14}$ It remains to be established whether local production of CRP is a generalized phenomenon of all vascular territories afflicted by atherosclerosis.

In the present study we studied the relation between serum CRP and the extent and progression of peripheral atherosclerotic disease, as well as the development of cardiovascular complications, in patients with PAD. We further assessed the possible production of CRP by atherosclerotic plaques of lower limb arteries.

\subsection{Materials and methods}

\subsubsection{Patients}

Patients with symptomatic PAD (ABPI<0.9) were recruited at the vascular clinic of a university medical centre and two affiliated teaching hospitals. Patients with a suspected acute phase reaction (CRP>10 mg/l) ${ }^{15}$ inflammatory comorbidity, malignancy, recent ( $<3$ months) antibiotic use, recent ( $<6$ months) vascular events or interventions, renal or liver failure, or limited life expectancy $(<2$ years) were not included. The study was approved by the medical ethics 
committee of all participating centres and conformed with the principles outlined in the declaration of Helsinki. ${ }^{16}$ All patients gave written informed consent.

\subsubsection{Assessment of ABPI}

The ABPI was measured in the supine position after a 15 -minute rest period. At inclusion the ankle pressure was measured in, both, the posterior tibial and dorsal pedal artery of the (most) symptomatic leg. The highest ankle-pressure was used to determine the ABPI. At follow-up visits, the blood pressure in the same crural artery was used to determine the follow-up ABPI.

\subsubsection{Risk factor profile}

At inclusion, the presence of classic atherosclerotic risk factors was assessed, i.e., smoking (currently smoking or stopped <10 years ago), diabetes (currently using antiglycemic medication or insulin or fasting blood glucose level $>7 \mathrm{mmol} / \mathrm{l}$ ), hypertension (currently using antihypertensive medication or systolic blood pressure $>160 \mathrm{mmHg}$ ), dyslipidemia (currently using antilipidemic medication or fasting cholesterol $>5 \mathrm{mmol} / \mathrm{l})$, and family history ( $1^{\text {st }}$ degree relative with ischemic cardiovascular disease before the age of 70).

\subsubsection{Follow-up and cardiovascular events}

All patients were followed up semi-annually for a variable time period, but minimally for one year. The median follow-up was 24 months and ranged from 12 to 48 months.

The primary endpoint was the combined variable 'all cause mortality and/or any cardiovascular event". Coronary events included myocardial infarction, de novo unstable angina pectoris, and any coronary revascularization procedure. A cerebral event was any stroke or transient ischemic attack. A peripheral arterial event was defined as any increase in peripheral ischemic symptoms (i.e., ischemic pain) that was accompanied either by a significant decrease in ABPI (i.e., $\triangle[A B P]]>0.1$ ) or by any peripheral revascularization procedure (percutaneous transluminal angioplasty or operation). To minimize the risk of scoring a revascularization as an event soon after inclusion in the study even though no actual progression in atherosclerotic disease had occurred, patients were admitted to the study only after a definitive inclusion vascular treatment plan had been designed for each patient (conservative vs, angioplasty vs. surgery). Only revascularization procedures that developed beyond this inclusion treatment plan were scored as events. 


\subsubsection{Serum CRP level}

Venous blood was obtained during baseline assessment. To obtain serum, blood was immediately centrifuged at $1200 \mathrm{rpm}$ at $4^{\circ} \mathrm{C}$ for 10 minutes, and the serum was stored at $-20^{\circ} \mathrm{C}$ until analysis.

CRP was determined highly sensitive (hSCRP) with the IMMULITE assay (Diagnostic Products Corporation Nederland BV, Breda, The Netherlands). It provides a detection limit of $0.10 \mathrm{mg} / \mathrm{l}$ (zero calibrator $+2 \mathrm{SD}$ ) and a measurable range of $0.1-500 \mathrm{mg} / \mathrm{l}$ (manufacturer's claim). The coefficient of variation of this assay depends on the average hsCRP values, and at our laboratory it varied from $2.1 \%$ to $6.7 \% .{ }^{17}$ This assay thus provides adequate precision for cardiovascular risk stratification, ${ }^{18}$ and it has been approved by the Food and Drug Administration for clinical use in the United States of America.

\subsubsection{Atherosclerotic vascular tissue}

Femoral endarterectomy specimens from 34 patients who underwent operation consecutively at our clinic were collected. Of these, 12 patients participated in the prospective, serological part of the study. Femoral plaques used for RT-PCR ( $n=14)$ were snap-frozen in liquid nitrogen and stored at $-80^{\circ} \mathrm{C}$ until analysis. Plaques for immunohistochemical analysis $(n=20)$ were formalin-fixed and paraffin-embedded.

\subsubsection{CRP RT-PCR and Immunohistochemical analysis}

The presence of messenger RNA points to active transcription of a gene implicating synthesis of the gene-product. To assess whether CRP was produced in femoral atherosclerotic plaques, the presence of CRP MRNA was determined in this tissue by RT-PCR as previously described. ${ }^{13}$

The presence and localization of CRP in atherosclerotic plaques of femoral arteries was further assessed immunohistochemically. In order to identify CRPpositive cells, smooth muscle cells, T-cells, and macrophages were stained immunohistochemically on serial tissue sections. Femoral atherosclerotic plaques $(n=20)$ were formalin fixed and embedded in paraffin. Serial $4 \mu \mathrm{m}$ sections were deparaffined and incubated with a monoclonal antibody directed against CRP, an $\alpha$-actin smooth muscle cell antibody, a CD-3 (T-cell) antibody and a CD-68 (macrophage) antibody (all from DAKO, Denmark). Subsequently, incubation with a rabbit anti mouse antibody (DAKO) and streptavidine biotine complex was performed in a multistep immunostaining procedure. The coloric reaction was created with diaminobenzidine. Two healthy brachial artery specimens obtained at post-mortem examination from fatal trauma victims were used as negative tissue control in each run. 


\section{3 .8 Statistics}

SPSS 10.0 for Windows (SPSS Inc, Chicago, III) was used for the statistics. The $x^{2}$-test was used for comparison of dichotomous/categorical variables. Spearman rank correlation was used to explore the association between serum $h s C R P$ and $A B P I$ at inclusion and at 12 months. The paired samples $t$ test was used for comparison of baseline and 12-month follow-up ABPI. After the patient population was divided into three equally sized groups according to baseline serum $h s C R P$, analysis of variance (ANOVA) with the Bonferroni correction was used to compare mean baseline and 12-month follow-up $\mathrm{ABPI}$ among the three groups. Parameters that were significantly associated with $A B P I$ in the univariate analyses were entered as potential confounders in a multivariate ANOVA to study the relationship between ABPI and serum hsCRP. KaplanMeier models with log rank statistics were constructed to compare freedom from clinical endpoints between patients in the three CRP groups. Cox proportional hazard models were used to correct for relevant co-variables.

\subsection{Results}

Patient characteristics and vascular status are shown in Table 2.1. The patients analyzed had severe PAD as revealed by an average (SD) baseline ABPI at inclusion of $0.64(0.18)$ (Table 2.2). After 12 months the average (SD) ABPI increased significantly to $0.72(0.20)$ (paired samples $t$ test, $P<0.001)$. This increase resulted mainly from interventions (Table 2.2)

The extent of systemic atherosclerotic disease in these patients was reflected in the high prevalence of coronary and cerebrovascular co-morbidity (Table 2.1) and in the significant number of cardiovascular and cerebrovascular complications and deaths during follow-up. Approximately one third of the PAD patients had coexisting coronary artery disease, and $16 \%$ had cerebrovascular comorbidities. During a 24-month follow-up period, 136 (35.1\%) PAD patients developed 184 vascular events (coronary, cerebral, peripheral) or died. Thirtytwo patients died (all-cause mortality), 29 developed 30 coronary events, 25 patients suffered 26 transient ischemic attacks or strokes and 76 had, in total, 96 peripheral arterial events (Table 2.3).

The median (inter-quartile range, IQR) serum hsCRP in PAD patients was 2.65 $(1.35-4.41) \mathrm{mg} / \mathrm{l}$. Because the mean $h s C R P$ value ( $3.26 \mathrm{mg} / \mathrm{l})$ was greater than $3 \mathrm{mg} / \mathrm{l}$, these patients should be considered as being at high risk for future complications according to guidelines from the American Heart Association and the Centres for Disease Control and Prevention. ${ }^{15}$ 
Table 2.1 Patient characteristics.

\begin{tabular}{|c|c|c|c|c|}
\hline & All patients & LOW CRP & Intermediate CRP & High CRP \\
\hline $\mathbb{N}$ & 387 & 129 & 129 & 129 \\
\hline Age, y mean (SD) & $65(9.5)$ & $64(8.9)$ & $65(10.4)$ & $66(8.7)$ \\
\hline Male / female & $264 / 123$ & $85 / 44$ & $88 / 41$ & $91 / 38$ \\
\hline Smoking $n$, $(\%)$ & $297(77)$ & $95(74)$ & $101(78)$ & $101(78)$ \\
\hline Dislipidemia $^{\circ}, \mathrm{n}(\%)$ & $321(83)$ & 108. (84) & $108(84)$ & $105(81)$ \\
\hline Hypertension ${ }^{2}$, n (\%) & $221(57)$ & $76 .(59)$ & $70(55)$ & $75(58)$ \\
\hline Diabetes $^{d}, n(\%)$ & $105(27)$ & $38(29)$ & $33(26)$ & $34(26)$ \\
\hline Positive Family History, $\mathrm{n}(\%)$ & $239(62)$ & $79(61)$ & $81(63)$ & $79(61)$ \\
\hline \multicolumn{5}{|l|}{ Diagnosis } \\
\hline Claudication, $n(\%)$ & $351(91)$ & $119(92)$ & $120(93)$ & $112(87)$ \\
\hline Critical limb ischemia, $n(\%)$ & $36(9)$ & $10(8)$ & $9(7)$ & $17(13)$ \\
\hline \multicolumn{5}{|l|}{ Treatment } \\
\hline Conservative, $\mathrm{n}(\%)$ & $273(70)$ & $90(70)$ & $90(70)$ & $93(72)$ \\
\hline Angioplasty: $n(\%)$ & $73(19)$ & $29(22)$ & $22(17)$ & $22(17)$ \\
\hline Surgery, n $(\%)$ & $41(11)$ & $10(8)$ & $17(13)$ & $14(11)$ \\
\hline \multicolumn{5}{|l|}{ Vascular co-morbidity } \\
\hline CAD & $125(32)$ & $42(33)$ & $41(32)$ & $42(33)$ \\
\hline CVD & $62(16)$ & $13(10)$ & $28(22)$ & $21(16)$ \\
\hline AAA & $37(10)$ & $15(12)$ & $9(7)$ & $13(10)$ \\
\hline \multicolumn{5}{|l|}{ Medication } \\
\hline Acetylsalicylic acid, $n(\%)$ & $362(93)$ & $120(93)$ & $123(95)$ & $119(92)$ \\
\hline Coumarin, $n(\%)$ & $42(11)$ & $12(9)$ & $15(12)$ & $15(12)$ \\
\hline B-Blocker, $n(\%)$ & $121(31)$ & $43(33)$ & $39(30)$ & $39(30)$ \\
\hline RAS inhibilor, n (\%) & $129(33)$ & $46(36)$ & $40(31)$ & $43(33)$ \\
\hline Calcium channel blocker, n (\%) & $110(28)$ & $32(25)$ & $40(31)$ & $38(29)$ \\
\hline Statin $\cap(\%)$ & $321(83)$ & $108(84)$ & $108(84)$ & $105(81)$ \\
\hline
\end{tabular}

CRP: C-reactive protein; CAD: coronary artery disease; CVD: cerebrovascular disease; AAA: abdominal aortic aneurysm; RAS: rennin-angiotensin system.

a currently smoking or stopped less than 10year ago; ${ }^{\text {b }}$ fasting cholesterol level>5.1 mmoll/, triglyceride level $>1.95 \mathrm{mmol} / \mathrm{h}$, or the use of antidyslipidemic medication;" systolic blood pressure $>160 \mathrm{mmH}$ ig , diastolic blood pressure $>95 \mathrm{mmHg}$, or the use of antihypertensive medication; "fasting glucose level $>7 \mathrm{mmol} / /$ or the use of antiglycemic medication or insulin" "firstdegree relative with first ischemic cardiovascular event before age of 70 years.

Serum hsCRP was related to severity of PAD. Baseline serum hsCRP was significantly correlated with the ABPI at inclusion (Spearman's $\rho=-0.306$, $P<0.011$ ), and with the ABPI at 12 months (Spearman's $\rho=-0.256, P<0.01$ ). When patients were divided into three equally sized groups according to baseline hsCRP level, - low hsCRP group (CRP $\leq 1.72$ ), intermediated hsCRP group $(1.72<h s C R P \leq 3.56)$, and high $h s C R P$ group ( $h s C R P>3.56)-\mathrm{ABPI}$ at inclusion decreased from lowest to upper tertile (average baseline ABPl: 0.70 , 0.65 , and 0.57 in the low, intermediate and high hsCRP group, respectively; ANOVA, $P=0.001$ for the trend; Figure 2.1a). This association persisted after correcting for relevant risk factors, i.e., diabetes, hypertension, smoking, age, sex and critical limb ischemia (multivariate ANOVA, $P=0.001$ for the trend). Intriguingly, the ABPI at 12 month follow-up, showed a similar significant 
decrease with baseline serum hsCRP (average 12 month follow-UP ABPI: 0.78 , 0.70 and 0.65 in the low, intermediate and high hsCRP group, respectively, ANOVA, $P=0.001$; Figure 2.1b). Again, the association between baseline hsCRP and ABPI at 12 months persisted after correction for the risk factors mentioned above (multivariate ANOVA, $P=0.001$ for the trend).

Table 2.2 ABP at inclusion and after 12 months" follow-up in the entire PAD patient population and in the subgroups of patients with or without an intervention within one year after inclusion.

\begin{tabular}{lccc}
\hline & $\begin{array}{c}\text { Entire population } \\
(\mathbb{N}=387)\end{array}$ & $\begin{array}{c}\text { Patients without } \\
\text { intervention }(\mathbb{N}=259)\end{array}$ & $\begin{array}{c}\text { Patients undergoing } \\
\text { intervention }(N=128)\end{array}$ \\
\hline ABPl at inclusion & $0.64(0.18)$ & $0.67(0.18)$ & $0.59(0.17)$ \\
ABPI at 12 months & $0.72(0.20)$ & $0.69(0.18)$ & $0.76(0.23)$ \\
P(paired sample T test) & 0.001 & 0.001 & 0.001 \\
\hline
\end{tabular}

ABPl: ankle-brachial pressure index; PAD: peripheral arterial disease. Data are mean (SD) ABPI.

Serum hsRP exhibited a relation with the occurrence of complications during follow-up. The incidence of all vascular events increased from the low hsCRP group to the high hsCRP group (Table 2.3 ). However, only for the combined endpoint did this association reach a statistically significant level $\left(\chi^{2}\right.$ for trend, $P=0.020$ ). Accordingly, the freedom from any clinical endpoint seemed shorter with higher baseline serum hsCRP. Again, only for the combined endpoint of all cause mortality and/or any cardiovascular complication did this association reach statistical significance ( $\log$ rank statistics, $P=0.036$, Figure 2.2). The significance of this relation survived correction for conventional cardiovascular risk factors and clinical severity of PAD in a Cox proportional hazards model $(P=0.003)$.

Table 2.3 Incidence of cardiovascular events in PAD patients with low, intermediate or high baseline serum insCRP level.

\begin{tabular}{lccccc}
\hline & Total group & $\begin{array}{c}\text { Low } \\
\text { CRP group } \\
(\mathrm{N}=129)\end{array}$ & $\begin{array}{c}\text { Intermediate } \\
\text { CRP group }^{c} \\
(\mathrm{~N}=129)\end{array}$ & $\begin{array}{c}\text { High } \\
\text { CRP group } \\
(\mathrm{N}=387)\end{array}$ & P $^{\text {st }}$ \\
\hline Combined endpoint & $136(35.1)$ & 33 & 51 & 52 & 0.020 \\
Death & $32(8.2)$ & 6 & 12 & 14 & 0.170 \\
Coronary endpoint & $29(7.4)$ & 7 & 12 & 10 & 0.493 \\
Cerebral endpoint & $25(6.5)$ & 6 & 7 & 12 & 0.266 \\
Peripheral endpoint & $76(19.6)$ & 23 & 28 & 25 & 0.733 \\
\hline
\end{tabular}

PAD: peripheral arterial disease; hSCRP: highly sensitive C-reactive protein. Data are numbers (percentages) of patients with an event a $x^{2}$-test for trend; "Iow CRP group: CRP $\leq 1.72$; intermediated CRP group: $1.72<$ hsCRP $\leq 3.56$; ${ }^{d}$ high CRP group: $h s C R P>3.56$ 

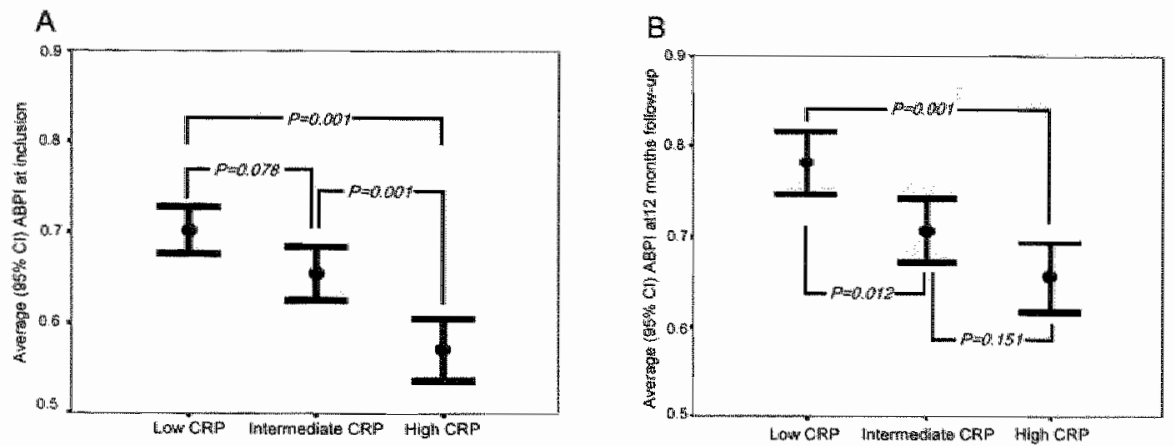

Figure 2.1 Relationship between ankle-brachial pressure index ( $\mathrm{ABP}$; at inclusion and at 12 months) and serum hsCRP at inclusion.

A: The average $\mathrm{ABPI}$ at inclusion decreased from the low CRP group to the high CRP group (analysis of variance [ANOVA]; $P_{\text {trend }}=0.001$ ). $B$ : The average $A B P$ : at 12 months" follow-up also decreased from thigh to low baseline serum hsCRP (ANOWA, $P_{\text {trend }}=0.001$ ). Cl: confidence interval.

Fourteen atherosclerotic femoral plaques from 14 patients undergoing vascular surgery of the lower limb were analysed by RT-PCR to assess the local production of CRP in femoral atherosclerotic plaques. Four $(29 \%)$ of the 14 plaques showed evidence of CRP messenger RNA production. The house keeping gene cyclophylin was detected in all samples (Figure 2.3).

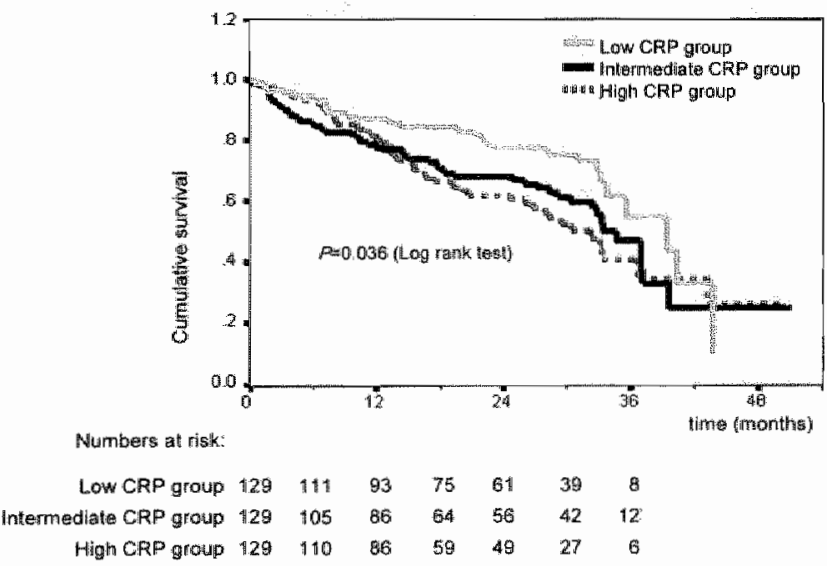

Figure 2.2 Difference in freedom from the combined endpoint 'death and/or any vascular event' (coronary, cerebral, peripheral) among patients with low vs. intermediate wis. high $C$-reactive protein (CRP, log rank statistics, $P=0.036$ ). This association persisted after correction for conventionall cardiovascular risk factors and clinical extent of peripheral arterial disease (Cox proportional hazards model, $P=0.003$ ). 
Furthermore, immunohistochemical analysis of 20 femoral atherosclerotic plaques from 20 consecutive patients and two healthy brachial arteries showed omnipresence of CRP in all plaques and almost complete absence of CRP in normal arteries (Figure 2.4). CRP-immunoreactive cells were also positive for CD-3 (T-cells), $a$-actin (smooth muscle cells) or CD-68 (macrophages) (Figure 2.4).

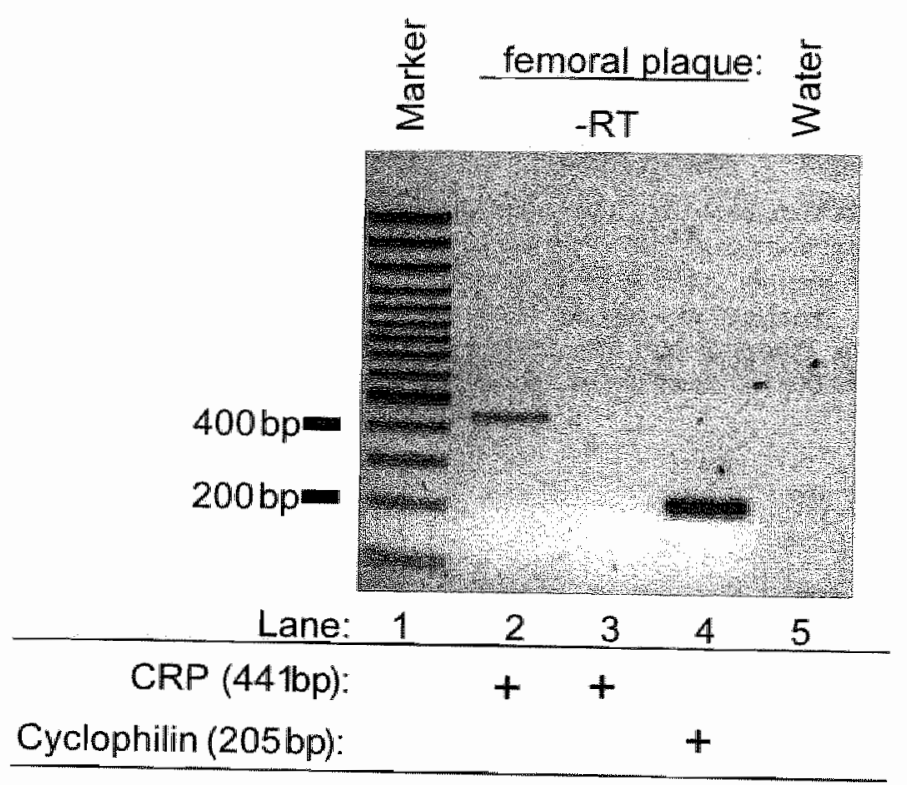

Figure 2.3 Representative gell showing C-reactive protein (CRP) messenger RNA in femoral atherosclerotic plaque from a patient with peripheral arterial disease. Lane 1 contains a marker for size (SmartLadder, Eurogentec Seraing. Belgium). Lane 2 has been loaded with CRP amplification product from femoral plaque. Lane 3 has been loaded with femoral plaque CRP amplification product without prior transcription of RNA into complementary DNA (-RT), demonstrating the specific amplification of RNA instead of genomic DNA. Lane 4 was loaded with cyclophilin polymerase chain reaction product from fernoral plaque and lane 5 was loaded with water. 


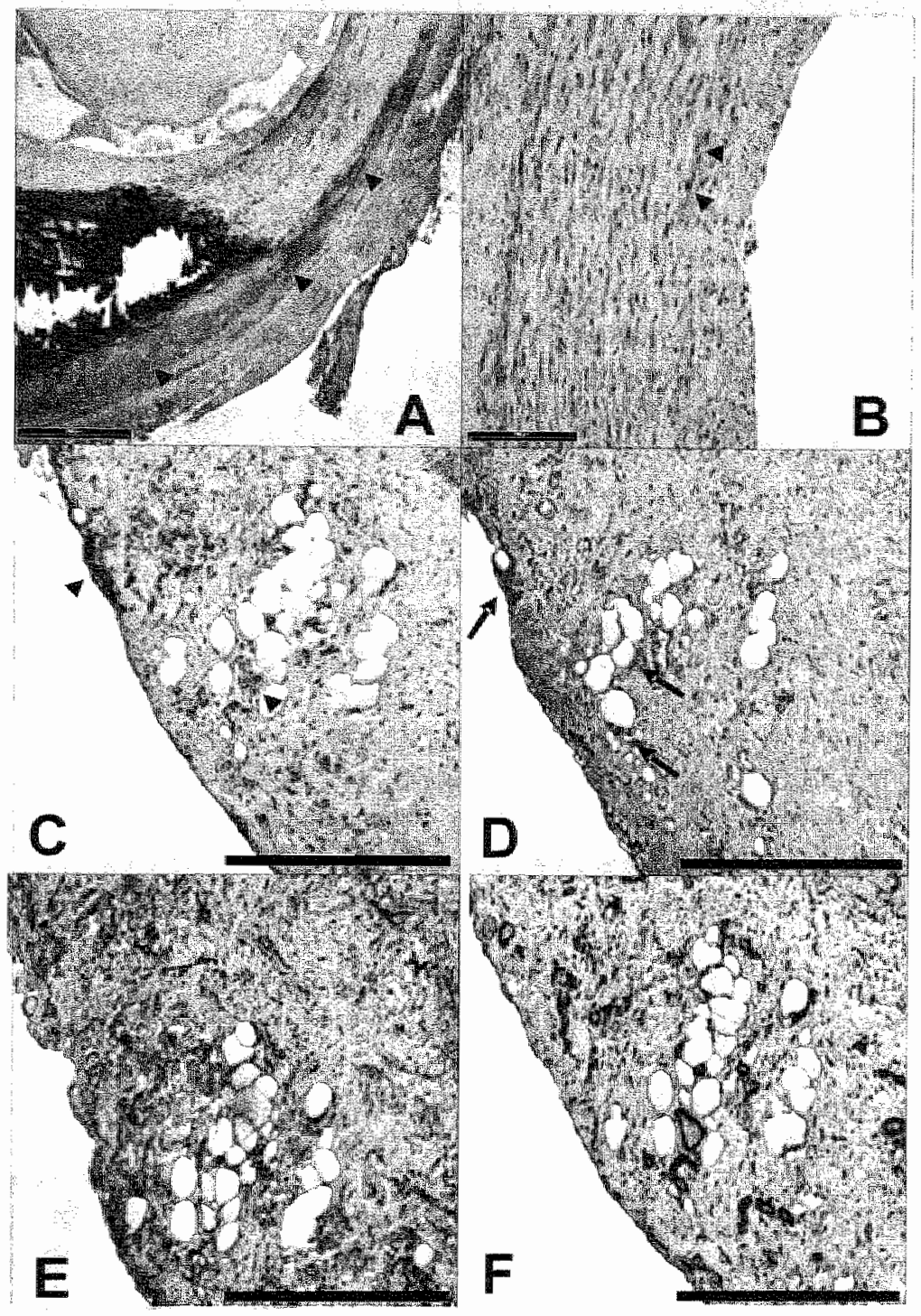

Figure 2.4 Immunohistochemical detection of C-reactive protein (CRP) in femoral aherosclerotic plaques and apparently healthy brachial artery. CRP was abundantly present in femoral atherosclerotic plaque (A) and almost completely absent in healthy tissue (B). CRP immunostaining (C) co-localized with T-cells (D). smooth muscle cells (E) and macrophages $(F)$ in serial tissue sections of femoral atherosclerotic plaques. 


\subsection{Discussion}

In this study, we assessed the association between hsCRP and the extent of atherosclerotic disease in PAD patients. Our data showed that PAD patients have increased serum hsCRP. Furthermore, hsCRP was inversely related to $A B P I$. This is in agreement with previous studies that showed that hsCRP is associated with hemodynamic $(\mathrm{eg}, \mathrm{ABPI})^{10}$ and functional (eg, outcome 6 -minute walk $)^{11}$ outcomes, and with clinical severity of PAD. ${ }^{19}$ Previously published data have shown that preprocedural serum CRP is independently related to early and late clinical cardiovascular events and to restenosis after coronary percutaneous intervention. ${ }^{20.21}$ Accordingly, our data showed that baseline serum $h s C R P$ was inversely related to ABPI measured 12 months later. This may suggest that high baseline serum hsCRP may identify patients that are most likely to develop restenosis or experience accelerated atherosclerosis of the native lower limb arteries. Serum hsCRP has been associated with the development of complications of the coronary, cerebral and peripheral arterial circulation in apparently healthy individuals. ${ }^{4-7}$ With this prospective study we were able to demonstrate that serum hsCRP was also related to the development of atherosclerosis-related events or death in PAD patients. To the best of our knowledge, this is the first study to demonstrate that serum hsCRP is related to future hemodynamic function and future cardiovascular events in patients with PAD. Hence, serum hsCRP may be used to estimate the extent of atherosclerotic disease, and may facilitate cardiovascular risk estimation in PAD patients and healthy individuals. Additionally, recently published data have demonstrated that decreasing serum CRP by statins resulted in a significant reduction of cardiovascular event rate regardless of the resultant low-density lipoprotein cholesterol level. Consequently, cardiovascular risk-reduction strategies involving statins should include serum CRP monitoring. ${ }^{22}$

It is believed that cytokine-stimulated production of CRP by hepatocytes is responsible for the elevated CRP levels in atherosclerosis. Localization of CRP extracellularly and in macrophages shown in human atherosclerotic aortic lesions was thought to result from uptake of CRP-lipid complexes by macrophages. ${ }^{23}$ However, recent evidence suggests that diseased vascular tissue can produce CRP as well. Coronary plaques, ${ }^{12}$ aneurysmal aortas ${ }^{13}$ and failed venous coronary bypasses ${ }^{14}$ have shown to produce CRP. In this study. we demonstrated that femoral atherosclerotic plaques produce CRP as well. Using immunohistochemical staining on serial tissue sections we identified smooth muscle cells, macrophages and T-cells as the putative cellular production sites of CRP. Yasojima et al. have suggested that smooth musclelike cells and macrophages produce CRP in coronary atherosclerotic plaque, ${ }^{12}$ whereas Kuta $\mathrm{et} a f^{24}$ and Ikuta et $a .^{25}$ independently showed that lymphocytes 
produce CRP when stimulated with LPS or 10-O-tetradecanoyl-phorbol-13acetate, respectively.

Considering the presence and local production of CRP in atherosclerotic tissue it is logical to assume that CRP actively participates in the atherosclerotic process. Recent evidence suggests that CRP has proatherogenic effects on all cellular constituents of the vascular wall. CRP co-localizes with the membrane attack complex in atherosclerotic plaques and activates complement. ${ }^{12,26} \mathrm{CRP}$ is chemotactic for circulating monocytes, ${ }^{27}$ stimulates monocyte tissue factor production, ${ }^{28}$ up-regulates some macrophage pro-inflammatory cytokines, ${ }^{29}$ and causes a sustained increase in native low-density lipoprotein uptake by macrophages. ${ }^{30}$ Through activation of nuclear factor KB, CRP may induce endothelial adhesion molecules, ${ }^{31}$ stimulate endothelial monocyte chemoattractant protein-1 release, ${ }^{32}$ and inhibit basal and stimulated endothelial nitric oxide release. ${ }^{33}$ Similarly, CRP activates monocyte chemoattractant protein-1, interleukin 6 and inducible nitric oxide synthetase expression in vascular smooth muscle cells. ${ }^{34}$ The majority of the above described pro-inflammatory effects have been demonstrated in vitro using CRP concentrations ranging between 5 and $900 \mathrm{mg} / \mathrm{l}$. Therefore, it has recently been questionedl whether plasma concentration of CRP used to denote a high risk for future cardiovascular complications $(>3 \mathrm{mg} / \mathrm{l})$ are able to elicit these proinflammatory effects in the vascular wall. ${ }^{35}$ Local production of CRP in the vascular wall as demonstrated in the present paper may overcome this problem by yielding high CRP concentrations in the microenvironment of the atherosclerotic vessel wall.

The associations described here reflect the inflammatory nature of atherosclerosis. Because chronic infections have also been associated with atherosclerosis development as well, ${ }^{36}$ it is very reasonable to suggest that micro-organisms may be related to the increased serum CRP levels in atherosclerotic patients. In our study population, Chlamydia pneumoniae serology was not related to the serum CRP concentration. Furthermore, although both Chlamydia pneumoniae seropositivity (see chapter 8 ) and serum CRP had an independent effect on cardiovascular events, we were not able to demonstrate a synergistic effect of these variables on cardiovascular risk. This may be related to the fact that only patients with no recent infections and vascular interventions were analyzed. Additionally, it is more likely that total pathogen burden rather than infection with one micro-organism may be related to CRP levels and cardiovascular risk.

In conclusion, our data demonstrate that in addition to being a marker of atherosclerosis, CRP is produced within the atherosclerotic plaque and may locally participate in plaque development. Unravelling the parameters governing vascular CRP production may offer new ways of interfering with atherogenesis. 


\subsection{References}

1. Weijenberg MP, Feskens EJ. Kromhout D. White blood cell count and the risk of coronary heart disease and all-cause mortality in elderly men. Arterioscter Thromb Vasc Biol. $1996 ; 16: 499-503$.

2. Gillum RF, Mussolino ME, Makuc DM. Enythrocyte sedimentation rate and coronary heart disease: the NHANES I Epidemialogic Follow-up Study. JChn Epidemiol, 1995;48:353-61.

3. Haverkate F, Thompson SG, Pyke SD, Gallimore JR, Pepys MB. Production of C-reactive protein and risk of coronary events in stable and unstable angina. European Concerted Action on Thrombosis and Disabilities Angina Pectoris Study Group. Lancet 1997;349:462-6.

4. Tracy RP, Lemaitre RN "Psaty BM, Ives DG, Evans RW, Cushman M, Meilahn EN "Kuller LH. Relationship of C-reactive protein to risk of cardiovascular disease in the elderly. Results from the Cardiovascular Health Study and the Rural Health Promotion Project. Arterioscler Thromb Vasc Biol. 1997:17:1121-7.

5. Ridker PM, Custiman M, Stampfer MU, Tracy RP. Hennekens $C H$. Inflammation, aspirin, and the risk of cardiowascular disease in apparently healthy men. N Engl J Med. 1997;336:973-9.

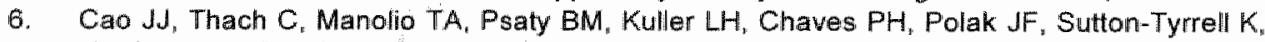
Herrington DM. Price TR, Cushman M. Cureactive protein, carotid intima-media thickness, and incidence of ischemic stroke in the elderly: the Cardiovascular Health Study. Circulation. 2003; 108:166-70.

7. Ridker PM, Cushman M, Stampfer MJ, Tracy RP. Hennekens $\mathrm{CH}$. Plasma concentration of C-reactive protein and risk of developing peripheral vascular disease. Circulation. 1998:97:425-8:

8. Dormandy JA, Rutherford RB. Management of peripheral arterial disease (PAD). TASC Working Group. TransAtlantic Inter-Society Concensus (TASC). J Vasc Surg. 2000;31:S1. 5296.

9. Brevetti G, Silvestro A, Di Giacomo S, Bucur R. Di Donato A, Schiano V. Scopacasa F. Endothelial dysfunction in peripheral arterial disease is related to increase in plasma markers of inflammation and severity of peripheral circulatory impairment but not to classic risk factors and atherosclerotic burden. J Wasc Surg. 2003;38-374-9.

10. McDermott MM, Green D, Greenland P. Liu K, Criqui MH, Chan C, Guralnik JM, Pearce WH, Ridker PM, Taylor L, Rifai N, Schneider JR. Relation of levels of hemostatic factors and inflammatory markers to the ankle brachial index. Am J Cardiol. 2003,92:194-9

11. McDermott MM, Greenland P, Green D, Guralnik JM, Criqui MH, Liu K, Chan C, Pearce WH, Taylor L. Ridker PM, Schneider JR, Martin G, Rifai N, Quann M, Fornage M. D-dimer, inflammatory markers, and lower extremity functioning in patients with and without peripheral arterial disease. Ciroulation. 2003;107:3191.8.

12. Yasojima K, Schwab C, McGeer EG, McGeer PL. Generation of C-reactive protein and complement components in atherosclerotic plaques. Am J Pathol. 2001;158:1039-51.

13. Vainas $T$, Lubbers $T$. Stassen FRM, Herngreen SB, van Dieijen-Visser MP. Bruggeman CA, Kitslaar PJEHM, Willem H. Schurink G. Serum C-Reactive Protein Level is Associated With Abdominal Aortic Aneurysm Size and May Be Produced by Aneurysmal Tissue. Circulation.
2003:107:1103m1105.

14. Jabs WJ. Theissing E, Nitschke M, Bechtel .JF, Duchrow M, Mohamed S, Jahrbeck B, Sievers $H H$, Steinhoff $J$, Bartels $C$. Local generation of C-reactive protein in diseased coronary artery venous bypass grafts and normal vascular tissue. Circulation. 2003;108:1428-31

15. Pearson TA, Mensah GA. Alexander RW, Anderson JL, Cannon RO, III. Criqui M, Fadl YY.

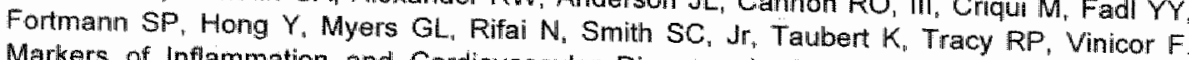
Markers of Inflammation and Cardiovascular Disease: Application to Clinical and Public Health Practice: A Statement for Healthcare Professionals From the Centers for Disease Control and Prevention and the American Heart Association. Circulation. 2003;107:499-511. 16. World Medical Association Deciaration of Helsinki. Recommendations guiding physicians in
biomedical research involving human subjects. Cardiovasc Res. 1997;35:2-3. 
17. Rothikrantz-Kos $S$, Schmitz MP. Bekers $O$, Menheere PP, van Dieijen-Visser MP. Highsensitivity C-reactive protein methods examined. Clin Chem. 2002;48:359-62.

18. Macy EM, Hayes TE, Tracy RP. Variability in the measurement of C-reactive protein in healthy subjects: implications for reference intervals and epidemiological applications. Clin Chem. 1997:43:52-8.

19. Majewski W, Zielinski A, Laciak M. Staniszewski R, Gorny A, Zapalski S, Mackiewicz A. Oreactive protein and alpham 1-acid glycoprotein in monitoring of patients with chronic arterial occlusion of the lower limbs. Eur J Vasc Surg. 1993;7:628-32.

20. Rahel $B M$, Visseren $F L$, Suttorp MJ, Plokker TH, Kelder JC, de Jongh BM, Bouter KF, Diepersloot RJ. Preprocedural serum levels of acute-phase reactants and prognosis after percutaneous coronary intervention. Cardiovasc Res. 2003;60:136-40.

21. Buffon $A$, Liuzzo G. Biasucci LM, Pasqualletti P. Ramazzotti $V$, Rebuzzi AG, Crea F, Maseri A. Preprocedural serum levels of C-reactive protein predict early complications and late restenosis after coronary angioplasty. J Am Coll Cardiol 1999;34:1512-21.

22. Ridker PM, Cannon CP, Morrow D, Rifai N, Rose LM, McCabe CH, Pfeffer MA, Braunwald E. C-reactive protein levels and outcomes after statin therapy. N Engl J Med, 2005;352:20-8.

23. Hatanaka $\mathrm{K}, \mathrm{Li}$ XA, Masuda $\mathrm{K}$, Yutani $\mathrm{C}$, Yamamoto $\mathrm{A}$. Immunohistochemical localization of $C$-reactive protein-binding sites in human atherosclerotic aortic lesions by a modified streptavidin-biotin-staining method. Pathol /nt. 1995;45:635-41.

24. Kuta $A E$, Baum LL. C-reactive protein is produced by a small number of normal human peripheral blood lymphocytes. J Exp Med. 1986;164:321-6.

25. Ukuta $T$, Okuba $H$, lshibashi $H$, Okumura $Y$, Hayashida $K$. Human lymphocytes synthesize $C$ reactive protein. Inflammation. 1986;10:223-32.

26. Torzewski J, Torzewski $M$, Bowyer DE , Frohlich $M$, Koenig $W$, Waltenberger J, Fitzsimmons

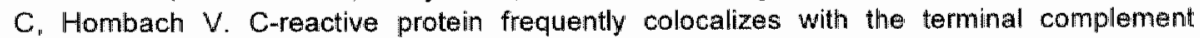
complex in the intima of early atherosclerotic lesions of human coronary arteries. Arterioscler Thromb Vasc Biol. 1998;18:1386-92.

27. Torzewski $M$, Rist $C$, Mortensen RF, Zwaka TP, Bienek $M$, Waltenberger J, Koenig $W$, Schmitz $G$, Hombach $W$, Torzewski J. C-reactive protein in the arterial intima: role of $C$ reactive protein receptor-dependent monocyte recruitment in atherogenesis. Arterioscler Thromb Vasc Biol. 2000;20:2094-9.

28. Cermak J, Key NS, Bach RR, Balla J, Jacob HS, Vercellotti GM. C-reactive protein induces human peripheral blood monocytes to synthesize tissue factor. Blood. 1993;82:513-20.

29. Ballou SP, Lozanski $G$. Induction of inflammatory cytokine release from cultured human monocytes by C-reactive protein. Cytokine. 1992;4:361-8.

30. Verma $\mathrm{S}, \mathrm{Li}$ SH, Badiwala MV, Weisel RD, Fedak PW, Li RK, Dhillon B, Mickle DA. Endothelin antagonism and interleukin-6 inhibition attenuate the proatherogenic effects of $\mathrm{C}$ reactive protein. Circulation. 2002; 105:1890-6.

31. Pasceri $V_{\text {s }}$ Willerson JT, Yeh ET. Direct proinflammatory effect of C-reactive protein on human endothelial cells. Circulation. 2000;102:2165-8.

32. Pasceri $V$, Chang J, Willerson JT, Yeh ET. Modulation of c-reactive protein-mediated monocyte chemoattractant protein-1 induction in human endothelial cells by antatherosclerosis drugs. Circulation. 2001:103:2531-4.

33. Werma $S$, Wang CH, Li SH, Dumont AS, Fedak PW, Badiwala MV, Dhillon B, Weisel RD, Li RK, Mickle DA, Stewart DJ. A self-fulfilling prophecy: C-reactive protein attenuates nitric oxide production and inhibits angiogenesis. Circulation. 2002;106:913-9.

34. Hattori $Y$, Matsumura M, Kasai K. Vascular smooth muscle cell activation by C-reactive protein. Cardiovasc Res. 2003;58:186-95.

35. Blake GJ, Ridker PM. C-reactive protein: a surrogate risk marker or mediator of atherothrombasis? Am I Physiol Regul integr Comp Physiol. 2003:2003:R1250-2.

36. Leinonen $M$, Saikku $P$. Evidence for infectious agents in cardiovascular disease and atherosclerosis. Lancet infect Dis. 2002;2:11-7. 
60 


\section{Chapter 3}

Serum C-reactive protein level is associated with abdominal aortic aneurysm size and the protein may be produced by aneurysmal tissue

Vainas T, Lubbers T, Stassen FR, Herngreen SB, van Dieijen-Visser MP, Bruggeman CA, Kitslaar PJ, Schurink GW

Circulation 2003;107:1103-07 


\subsection{Abstract}

\section{Background}

Abdominal aortic aneurysms. (AAA) are characterized by extensive transmural inflammation and C-reactive protein (CRP) has emergied as independent risk factor for the development of cardiovascular disease. Therefore, we revaluated a possible association bewween serum CRP and aneurysm dimenision in patients with asymptomatic AAA. Furthermore the possibility of CRP production by aneurysmal tissue has been examined.

Patients \& methods

Serum CRP was determined highty sensitive (hSCRP) and aneurysmal size was measured in 39 patients with AAA. The presence of CRP messenger RNA was assessed in aneurysmal tissue of 16 patients.

\section{Results}

Mean (SD) hsCRP was $3.23(2.96) \mathrm{mg} / \mathrm{l}$. After log-tiansformation, hsC.RP correlated significantly with aneurysm size $(r=0.477, \rho=0.002)$. When the patients were divided into 3 equally sized groups according to hscRP level, aortic diameter increased from lowest to upper hsCRP-tentile (49mm, $64 \mathrm{~mm}$, and $67 \mathrm{~mm}$ respectively; $P<0.05$ for $3 \mathrm{rd} v \mathrm{~s}$. 1st tertile). This association persisted after correction for risk factors. CRP messenger RNA was found in $25 \%$ of anelurysmall aortic tissues.

Conciusion

This is the first report showing that serum toCRP is associated with aneulrysm size and that -in at least some patients- CRP may be produced by aneurysmal tissue. These data underscore the inflammatory nature of AAA formation, suggesting that serum hsCRP may serve as marker of AAA disease and that CRP produced in vascular tissue might contribute to aneurysm formation. 


\subsection{Introduction}

The degenerative form of the abdominal aortic aneurysm (AAA) is a medial disease characterized by dilatational remodeling with degradation of extracellu-

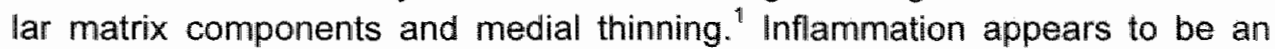
important component of aneurysm formation as illustrated by the extensive medial/adventitial inflammatory cell infiltrations. ${ }^{2}$ Accordingly, increased expression of pro-inflammatory cytokines can be found in aneurysmal tissue, ${ }^{3.4}$ and circulating levels of inflammatory cytokines are elevated in patients with $\mathrm{AAA}^{5.6}$ The serum concentration of several cytokines is associated with aneurysm diameter (interleukin-8), ${ }^{5}$ AAA symptomatology (tumour necrosis factor- $\alpha)_{1}^{5}$ and increased AAA expansion rate (interferon- $\gamma$ ). ${ }^{6}$

C-reactive protein (CRP) has recently emerged as a strong independent risk factor for atherosclerosis and atherosclerosis-related complications in apparently healthy individuals and patients with cardiovascular disease. ${ }^{7,8}$ In 1987 , Powell and colleagues showed that, among patients undergoing elective aortic reconstruction, serum CRP was elevated in AAA-patients compared with patients with obstructive disease. ${ }^{9}$ Although subsequently elevated serum CRP has been reported in patients with symptomatic or ruptured AAA, this early observation of elevated CRP level in patients with asymptomatic AAA has not been verified. ${ }^{10}$ Therefore, in the present study, serum CRP was, for the first time, measured highly sensitive in patients with asymptomatic AAA. The association between serum CRP and AAA dimension, and the possibility of local CRP-production by aneurysmal tissue were also explored.

\subsection{Materials and methods}

Patients with AAA ( $n=39)$, admitted to the surgical clinic of the University Hospital of Maastricht for vascular reconstruction were included in this study. Patients with ruptured/symptomatic AAAs, recent infections, active inflarnmatory disorders and/or serum CRP>10 mg/l were excluded. The study was approved by the institutional medical ethical committee, and all patients gave written informed consent.

\subsubsection{Determination of serum CRP}

Venous blood samples drawn on admission were immediately centrifuged for 10 minutes at $1200 \mathrm{rpm}$ and at $4^{\circ} \mathrm{C}$. Serum was stored at $-20^{\circ} \mathrm{C}$ until analysis. CRP was determined highly sensitive (hsCRP) with the IMMULITE CRP method (Diagnostic Product Corporation). This assay provides a detection limit of $0.10 \mathrm{mg} / \mathrm{l}$ and has been approved by the Food and Drug Administration for clinical use in the USA. 


\subsubsection{AAA dimension}

Computer assisted tomography was used to visualize the aorta and to determine the maximal aneurysm diameter. Because of logistical reasons, echodoppler ultrasonography was used to determine aneurysm dimensions in 5 of the 39 patients. hsCRP-level and aneurysm size did not differ between patients who had tomography or ultrasonography (data not shown).

\subsubsection{CRP RT PCR}

Aneurysm tissue was snap frozen in liquid nitrogen after explantation and stored at $-80^{\circ} \mathrm{C}$ until analysis. Total RNA from approximately $0.1 \mathrm{~g}$ of each tissue sample $(n=16)$ was isolated according to the manufacturer's instructions using TRIZOL Reagent (Life Technologies). After treatment with DNAse I in the presence of RNA guard (both Amersham Pharmacia Biotech), the RNA concentration was determined measuring the optical density at $260 \mathrm{~nm}$. One microlitre of RNA was reverse transcribed into CDNA using oligo dT (RACE-1, Amersham Pharmacia Biotech) and Superscript II RNAse $\mathrm{H}^{-}$(Invitrogen). For every RNA isolate, a RT-PCR reaction was also performed in the absence of reverse transcriptase to demonstrate the specific amplification of messenger RNA instead of genomic DNA. For amplification of CRP the following primer pair (amplifying a $441 \mathrm{bp}$ sequence) was used: forward: 5'TCGTATGCCACCAAGAGACAAGACA-3', reverse: 5'-AACACTTCGCCTTGCACTTC ATACT-3'. Two microlitres CDNA were transferred to an amplification mixture containing HotStar Taq DNA polymerase (Qiagen) and amplified for 40 cycles. Amplification products were separated on a $1 \%$ ethidium bromide stained agarose gel. Resulting bands were imaged using a FluorChem ${ }^{\mathrm{TM}} 8000$ analyzer (Alpha Innotech Corporation). To control for the identity of the bands, PCR product was (i) sequenced and (ii) treated with the endonuclase Apal splitting the amplified CRP sequence in 2 fragments of $381 \mathrm{bp}$ and $60 \mathrm{bp}$ respectively. The CDNA of the housekeeping gene cyclophilin (primer pair: forward: 5"ATGGTCAACCCCACCGTGTTCTTCG-3; reverse: 5'-CGTGTGAAGTCACCA CCCTGACACA-3') was amplified in parallel in every run to control for RNA integrity.

\subsubsection{Statistical analysis.}

Pearson's $r$ was computed to explore the correlation between aneurysm size and log-transformed serum hsCRP. ANOVA was used to further study the univariate association between serum hSCRP and aneurysm dimension and to assess the independent effect of sex, age, smoking, hypertension, dislipidemia, diabetes and extent of vascular disease on aneurysm size. Parameters that associated significantly with aneurysm size in the univariate analyses were 
entered as potential confounders in a multivariate ANOVA to study the relation between aneurysm size and serum hsCRP.

\subsection{Results}

A total of 39 patients ( 5 women) aged $71( \pm 5)$ years with an atherosclerotic risk profile (hypertension, $74 \%$; diabetes, $15 \%$; dislipidemia, $74 \%$; smoking, $77 \%$ ) were included in this study. Seventy-seven percent of the patients had extensive vascular disease affecting at least 2 vascular territories (coronary, cerebral and/or aortofemoral).

\subsubsection{CRP in aneurysmal disease.}

The average (SD), $25^{\text {th }}, 50^{\text {th }}$, and $75^{\text {th }}$ percentile of serum hsCRP was 3.23 (2.96), 1.03, 1.71, and $4.99 \mathrm{mg} / \mathrm{l}$, respectively. CRP mRNA was detected in 4 of 16 tissue samples $(25 \%)$, whereas cyclophilin was detected in all samples (Figure 3.1).

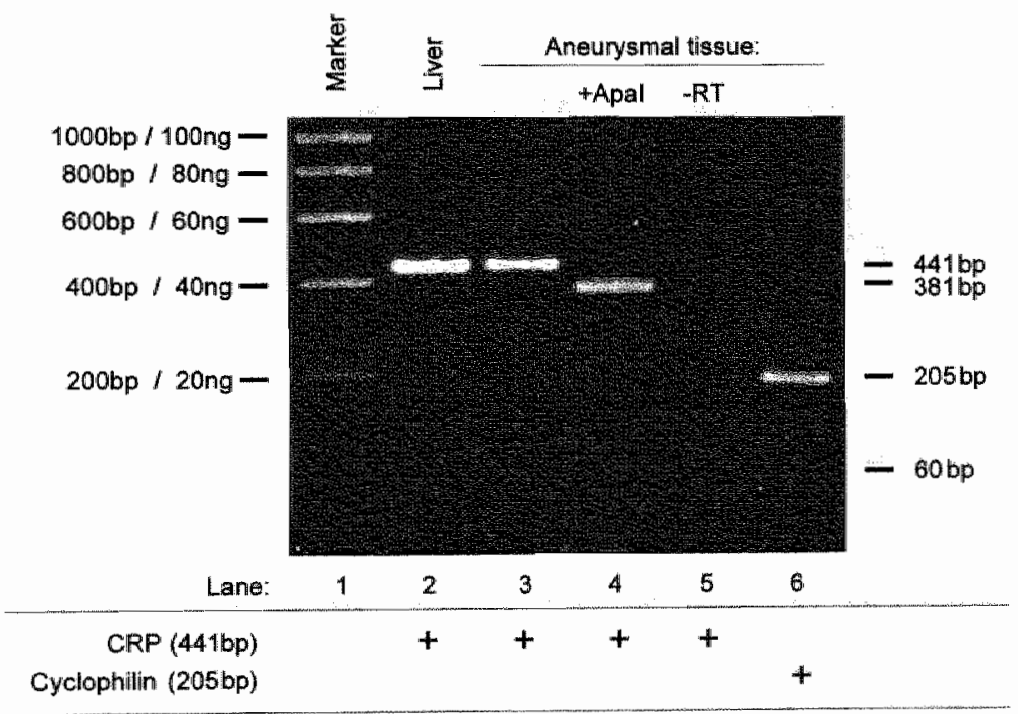

Figure 3.1 Representative gel showing CRP messenger RNA in a aneurysmal sample from a patient with AAA. Lane 1 contains a marker for size and quantity (SmartLadder ${ }^{\text {phat }}$, Eurogentec). CRP amplification product from human liver (lane: 2) and aneurysmal tissue (lane 3) are seen. Endonuclease treatment of aneurysmal CRP PCRmproduct with Apal yielded fragments of the expected size (lane 4) "whereas CRP amplification without prior transcription of RNA into CDNA (-RT) demonstrated the specific amplification of RNA instead of genomic DNA (lane 5). Lane 6 was loaded with cyclophilin PCR-product from aneurysmal tissue. 


\subsubsection{Aneurysm dimension and serum CRP}

The average (SD) maximal aneurysm dimension was 59 (15) $\mathrm{mm}$. Aneurysm size correlated with (log-transformed) serum hsCRP ( $r=0.477, P<0.002)$. When patients were divided into 3 equally sized groups according to hsCRP level (ii] $h s C R P<1.13$, [ii] $1.13 \leq h s C R P<4.15$, and [iii] $h s C R P \geq 4.15$ ), aortic diameter increased from lowest to upper tertile $(49 \mathrm{~mm}, 61 \mathrm{~mm}$, and $67 \mathrm{~mm}$ respectively; $p<0.05$ for $3^{\text {rd }} v s 1^{\text {st }}$ tertile; Table 3.1). From the risk factors for cardiovascular disease, only sex and diabetes showed an (trend towards) association with aneurysm size. When these confounders were entered in a multivariate model, the association between hsCRP and aneurysm size persisted. The corrected (for sex and diabetes) aneurysm diameter (mean [95\%-Cl], mm) of patients in the upper hsCRP tertile (73 [63-83], $P=0.003$ ) was significantly elevated, and that of the patients in the middle tertile (60 [51-68], $P=0.083)$ tended to be elevated compared to corrected aneurysm size of patients in the lowest $h s \mathrm{CRP}$ tertile (49 [40-58], Table 3.1).

Table 3.1 Mean (carrected) aneurysm size in 3 hsCRP-tertile groups.

\begin{tabular}{|c|c|c|c|c|c|}
\hline TSCRP tertile & $N$ & $\begin{array}{l}\text { Mean }(95 \%-\mathrm{Cl}) \\
\text { maximal diameter } \\
\text { (in } \mathrm{mm})\end{array}$ & $p^{a}$ & $\begin{array}{l}\text { Mean (95\%-CI) } \\
\text { corrected max. } \\
\text { diameter (in } \mathrm{mm} \text { ) }\end{array}$ & $P^{a}$ \\
\hline Lowest (AsCRP $<1.09 \mathrm{mg} / \mathrm{l})$ & 13 & $49(41-56)$ & - & $49(40-58)$ & - \\
\hline Middle $(1.09 \mathrm{mg} / 1 \leq h s \mathrm{C} R \mathrm{RP}<4.15 \mathrm{mg} / \mathrm{h})$ & 13 & $61(54-67)$ & 0.098 & $60(51-68)$ & 0.083 \\
\hline Upper (/ssCRP $\geq 4.15 \mathrm{mg} / \mathrm{s})$ & 13 & $67(57-78)$ & 0.004 & $73(63-83)$ & 0.003 \\
\hline
\end{tabular}

a for comparison with lowest tertile; ${ }^{\text {b }}$ correction for sex and diabetes.

\subsection{Discussion}

Moderately elevated serum hsCRP has been reported in patients with stenotic atherosclerotic disease, and is associated with an increased risk of developing cardiovascular events. ${ }^{7.8}$ However, scarce information exists about serum hsCRP in patients with aneurysmal disease. Powell ef al. showed that patients with asymptomatic AAA had increased serum CRP compared to patients with obstructive disease. ${ }^{9}$ The high mean serum CRP level $(56 \pm 10 \mathrm{mg} / \mathrm{l})$ reported, may reflect the suboptimal performance of the CRP-method used compared to modern highly sensitive assays or may suggest that patients with acute inflammatory conditions were included in that analysis. A recent study showed that patients with symptomatic and ruptured aneurysms had elevated serum CRP compared with patients with asymptomatic AAAs, but failed to verify the elevated serum CRP in asymptomatic AAA. ${ }^{10}$ The CRP assay used by these investigators lacked the sensitivity (detection limit $=5 \mathrm{mg} / \mathrm{l}$ ) to be used in the assessment of CRP in cardiovascular disease. ${ }^{11}$ In the present study, for the first time, serum CRP has been measured highly sensitive in patients with 
asymptomatic AAAs. Even though patients with symptomatic/ruptured AAA, active inflammatory/infectious disorders, or $h s C R P>10 \mathrm{mg} / \mathrm{l}$ were excluded, the mean serum $h s C R P$ was above the range for supposedly healthy individuals ${ }^{7}$ and was elevated compared to serum hsCRP of a healthy population measured in our lab. ${ }^{12}$

Intriguingly, serum hsCRP of asymptomatic AAA-patients showed in this study a strong association with aneurysm dimension. Despite the fact that $h s C R P$ has proven to be an independent risk factor for cardiovascular complications it remains unclear whether serum hsCRP would be a useful marker for the prediction of aneurysm growth and rupture in patients with AAA.

It is believed that moderately elevated serum $h s C R P(<10 \mathrm{mg} / l)$ results from chronic hepatic stimulation. However, it has been shown that CRP is produced in coronary plaques, ${ }^{13}$ Alzheimer's disease brain tissue, ${ }^{14}$ and myocardial infarcts. ${ }^{15}$ In the present study we were able to show that, in some patients, CRP was produced in aneurysmal tissue as well. These findings corroborate the notion that CRP upregulation is a generalized reaction to several types of tissue injury. Macrophages and smooth muscle cells might be the producers of 'vascular' CRP. ${ }^{13}$ Quantitative analysis of CRP mRNA and protein in normal and AAA tissue should give more insight into the up-regulation of CRP production during aneurysm formation.

In conclusion our data suggest that serum hsCRP is associated with aneurysm size in patients with asymptomatic AAA and that, in some cases, aneurysmal tissue is capable of producing CRP. Future studies should evaluate the usefulness of serum hsCRP as marker of disease progression and elucidate the role of locally produced CRP in AAA formation. 


\subsection{References}

1. Xu C, Zarins $C K$, Glagow S. Aneurysmal and acclusive atherosclerosis of the human abdominal aorta. I Vase Surg. 2001;33:91-6.

2. Koch $A E$, Haines GK, Rizzo RJ, et al. Human abdominal aortic aneurysms. Immunophenotypic analysis suggesting an immune-mediated response. Am J Pathot. 1990;137:1199-213.

3. Nowman $\mathrm{KM}$; Jean-Claude $J, \mathrm{LIH}_{i}$ ef all. Cytokines that activate proteolysis are increased in abolominal aortic aneurysms. Circulation. 1994,90:11224-7.

4. Shteinberg $D$, Halak $M$, Shapiro $S$, et al. Abdominal aortic aneurysm and aortic occlusive disease: a comparison of risk factors and inflammatory response. Eur J Vasc Endovasc Surg. $2000: 20: 462-5$.

5. Treska $V$, Topolcan $O$, Pecen $L$. Cytokines as plasma markers of abdominal aortic aneurysm. Clin Chem Lab Med 2000;38:1161-4.

6. Juvonen J, Surcel HM, Satta J, et al. Elevated circulating levels of inflammatory cytokines in patients with abdominal aortic aneurysm. Arterioscler Thromb Vasc Biol. 1997:17:2843-7.

7. Ridker PM, Cushman $M_{i}$ Stampfer MJ, et al. Inflammation, aspirin, and the risk of cardiovascular disease in apparently healthy men. N Eng/ J Med. 1997;336:973-9.

8. Lagrand $W K$, visser $C A_{\text {, Hermens }} W T$, et al. C-reactive protein as a cardiovascular risk factor: more than an epiphenomenon? Circulation. 1999;100:96-102.

9. Powell JT, Muller BR, Greenhalgh RM. Acute phase proteins in patients with abdominal aortic aneurysms. J Cardiovase Surg (Torino) 1987;28:528-30.

10. Domanovits $H$, Schillinger $M_{1}$ Mulliner $M$, al. Acute phase reactants in patients with abdominal aortic aneurysm. Atheroscterosis 2002;163:297-302.

11. Wood WG, Ludemann $J$. Mitusch R, et al. Evaluation of a sensitive immunoluminometric assay for the determination of C-reactive protein (CRP) in serum and plasma and the establishment of reference ranges for different groups of subjects. Clin Lab. 2000;46:131-40.

12. Rothkrantz-Kos $S$, Schmitz MP, Bekers $O$, et al. High-senisitivity C-reactive protein methods examined. Clin Chem. 2002;48:359-62.

13. Yasojima $K$, Schwab $C, M a G e e r E G$, et al. Generation of $C$-reactive protein and complement components in atherosclerotic plaques. Am J Pathol. 2001:158:1039-51.

14. Yasojima $K$, Schwab C, McGeer EG, et al. Human neurons generate $C$-reactive protein and amyloid P: upregulation in Alzheimer's disease. Brain Res. 2000;887:80-9.

15. Yasojima $K_{n}$ Schwab $C, M C G e e r E G$, et all. Human heart generates complement proteins that are upregulated and activated after myocardial infarction. Circ Res. 1998;83:860-9. 


\section{Section 3}

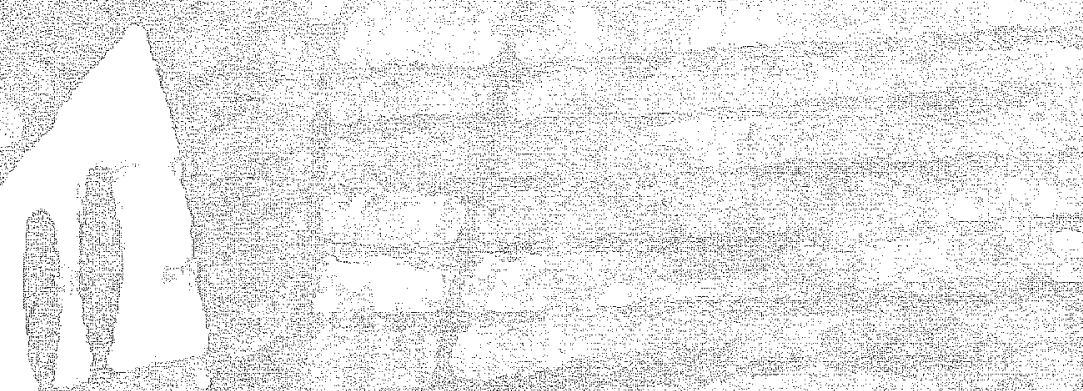

\section{Infection \& atherosclerosis}


73 


\section{Chapter 4}

Chlamydia pneumoniae serology: comparing a commercial enzyme immunoassay and microimmunofluorescence test in patients with cardiovascular disease

Vainas T, de Graaf R, Stassen FR, Kurvers HA, Grauls GE; Kitslaar PJ, Bruggeman CA 


\subsection{Abstract}

\section{Background}

Chlamydia pneumonize has been associated with cardiovascular disease and the detection of Chlamydia pneumonize antibodies has subsequently challenged many cardiovascular investigators. The micro-immunofluoresence (MIF) test is considered the gold standard for detection of chlamydia pneumoniae antibodies, but requires a high-level of expertise for adequate interpretation. Therefore, we compared the technically less demanding enzyme immunoassay (EIA) with the MIF test for the detection of Chlamydia pneumoniae antibodies in patients with cardiovascular disease.

Patients \& methods

Chlamidia pneumoniae $\mathrm{lgG}$ - and $\mathrm{lgA}$-antibodies were measured in sera of patients with cardiovascular disease $(n=141)$ using an ElA and a MIF test. The first 44 sera were tested in dupilicate by ElA in order to assess its intratest agreement. To define interobserver variability for the MIF test. MIF test results were read by two independent observers. Regarding the MIF test as gold standard, the sensitivity, specificity, positive and negative predictive value of the EIA for the detection of Chlamyolia pneumoniale $\lg \mathrm{G}$ - or $\mathrm{IgA}$-seropositivity using various cut-off levells for seropositivity, as well as the agreement (kappa) between EIA and MIF, were calculated.

\section{Riesults}

The interobserver agreement of the MIF-test for detection of seropositivity at various cut-off levels was good for $\operatorname{lgG}$ and for $\lg A$. The intratest agreement of the EIA was excellent for $\lg G$ and $\lg A$. The agreement between EIA and MIF in detection of IgG-and lgA-antibodies was adequate at low but not at high titre levels. At low titre levels, the sensitivity, specificity, positive and negative predictive value of EIA compared to the MIF-test was sufficient. The sensitivity of the EIA increased, improving the agreement with the MIF at high titre levels by retesting sera with elevated titres at higher pre-dilutions.

\section{Conclusion}

The EIA shows sufficient agreement with the MIF test in the detection of Chlamydia preumoniae seropositivity. Therefore, the EIA is a practical alternative to the MIF in the detection of Chlamydia pneumonize antibodies in patients with cardiovascular disease, bearing in mind that the sensitivity of the EIA depends on the antibody titre. 


\subsection{Introduction}

Chlamydia pneumoniae infections have been associated with the development of atherosclerotic disease of the coronary, cerebral and peripheral arterial system, ${ }^{1}$ opening the field of Chlamydia pneumoniae-related research to a vast number of non-microbiologically trained (cardiovascular) investigators and laboratories. As a result, various serological assays, immunoglobulin subtypes and different cut-off points have been employed in the sero-epidemiological studies analysing the association between Chlamydia pneumoniae infection and atherosclerotic disease, which may explain the conflicting results of hitherto published reports. ${ }^{2}$ Hence, the development of a simple and reliable detection assay for Chlamydia pneumoniae antibodies has become mandatory. Nowadays, the micro-immunofluorescence (MIF) test is considered the gold standard for the detection of Chlamydia pneumoniae antibodies during (acute) infections. ${ }^{3}$ Although this is a specific and sensitive test, it is also technically demanding, time-consuming and it is hampered by the subjective reading of the results. Several enzyme immunoassays (EIA) characterised by high throughput, objective endpoints, technical accessibility and cost effectiveness are commercially available. However, the performance of these assays compared to the MIF has yet to be properly evaluated.

In this study we evaluated the performance of an EIA compared with the MIF in the detection of Chlamydia pneumoniae IgA- and IgG-antibodies in patients with cardiovascular disease.

\subsection{Materials and methods}

Sera of patients admitted to the Vascular Surgical Clinic of Maastricht University Hospital were used for this analysis. All patients undergoing vascular reconstruction surgery for atherosclerotic disease whose serum was available for analysis were included. The study subjects $(n=141)$ represented a random subpopulation of vascular surgical patients treated between January 1, 1997 and December 31, 1998, at our vascular surgical clinic. The included patients underwent arterial reconstruction of the carotid artery $(n=33)$, aorta $(n=22)$ or lower limb arteries ( $n=86$ ). The study was approved by the local medical ethical committee and all patients gave their informed consent.

\subsubsection{Micro-immunofluorescence test (MIF)}

The commercial MIF-test is an indirect fluorescent antibody technique for measurement of IgG- and IgA-antibodies to Chlamydia pneumoniae. The test utilises purified , formalinized whole elementary bodies (EB) of Chlamydia 
pneumoniae, fixed onto microscope slides as distinct dots of antigen, leading to detection of surface exposed protein reactive antibodies. The MiF test was performed according to the instructions of the manufacturer (Labsystems; Helsinki, Finland). Briefly, serial serum dilutions were incubated with antigen on a microscope slide for 30 minutes. After slides were rinsed and dried, fluorescein isothiocyanate (FITC)-labelled anti-lgG or -lgA conjugates were applied and incubated for 30 minutes. A coverslip was mounted with appropriate mounting fluid over the antigen spot after the microscope slides were again rinsed and dried. The microscopic examination was done with a Zeiss Axioskop (Zeiss, Jena, Germany) with epilumination at 100x and $400 x$ magnification. According to the recommendations of a consensus committee, only evenly distributed, typical fluorescence of Chlamydia pneumoniae EBs was considered a positive reaction. ${ }^{3}$ Endpoints were read as the last serum dilution that exhibited specific fluorescence of the EBs throughout the antigen dot. Two experienced investigators evaluated the slides independently. Sera were tested at serial dilutions from $1 / 32$ to $1 / 512$ for IgG-, and from $1 / 8$ to $1 / 128$ for IgA-antibody titre determination.

\subsubsection{Enzyme immunoassay (E|A)}

The EIA used in this study was a commercially available test (Labsystems; Helsinki, Finland) detecting species-specific IgG- and IgA-antibodies to surface expressed proteins of Chlamydia pneumoniae. Sera were tested according to the instructions of the manufacturer. In short, serum diluted at $1 / 100$ was incubated with Chlamydia pneumoniae antigens coated onto a 96-well plate. After washing, horseradish peroxidase conjugated anti-immunoglobulin (IgG or IgA) was added to the wells and incubated for $60 \mathrm{~min}$ at room temperature. After further washing, the chromogen containing tetramethylbenzidine was added. The reaction was stopped with sulphuric acid after $30 \mathrm{~min}$ and optical density was immediately read at $450 \mathrm{~nm}$. Antibody titres were calculated from optical density readings in enzyme immuno-units (EIU) according to manufacturer's instructions. In the first 44 patients, IgG- and IgA-antibodies were determined in double serum samples. Due to the excellent agreement of the measured antibody titre in duplicate serum samples (see results). Chlamydia pneumoniae $\operatorname{lgG}$ and $\lg \mathrm{A}$ were determined in single serum specimens in the remaining 97 patients. According to the manufacturer the EIA has been developed so that the calculated EIUs correspond to the reciprocal of the titre determined with the MIF-test. Therefore, the EIU values calculated with the EIA were transformed into MIF titre categories (Table 4.1) in order to assess the agreement between the EIA and the MIF. 
Due to the weak agreement between the EIA and MIF at the high titre range (see results), sera with elevated titres (IgG $\geq 64$ EIUs or IgA 216 EIUs) were retested at a higher pre-dilution (1/400 in stead of $1 / 100)$.

Table 4.1 Transforming Chlamyolia pheumoniae antibody titre calculated with the ElA (in EUs) into MIF-titre categories.

\begin{tabular}{|c|c|c|c|}
\hline \multicolumn{2}{|c|}{$\lg G$} & \multicolumn{2}{|c|}{$\lg A$} \\
\hline ElA titre (EIU): & Corresponding MIF-titre & EIA titre (EIU): & Corresponding MIF-titre \\
\hline $\lg \mathrm{G}<32$ & 0 & $\lg A<8$ & 0 \\
\hline $32 \leq 19 G<64$ & $1 / 32$ & $8 \leq \lg A<16$ & $1 / 8$ \\
\hline $64 \leq \operatorname{lgG}<128$ & $1 / 64$ & $16 \leq \lg A<32$ & $1 / 46$ \\
\hline $128 \leq \| \mathrm{gG}<256$ & $1 / 128$ & $32 \leq \lg A<64$ & $1 / 32$ \\
\hline $256 \leq \lg G<512$ & $1 / 256$ & $64 \leq \lg A<128$ & $1 / 64$ \\
\hline $\lg G \geq 512$ & 1/512 & $\lg A \geq 128$ & $1 / 128$ \\
\hline
\end{tabular}

\subsubsection{Statistics}

SPSS 10.0 for windows (SPSS Inc. Chicago, Illinois, USA) was used for the statistical analysis. Pearson's correlation coefficient of the (log-transformed) ElA titre measurements in duplicate samples was computed. Spearman rank correlation between the two independent readings of the MIF test, and between the MIF and EIA titres (after transformation into MIF titre categories) was calculated. The intra-test and inter-test variability was assayed by calculating the coefficient of agreement kappa ( $\kappa)$. The sensitivity, specificity and positive(PPV) and negative predictive value (NPV) was calculated for detection of Chlamydia pneumoniae seropositivity using various cut-off points for $\operatorname{lgG}$ and IgA, regarding the MiF-test as the gold standard.

\subsection{Results}

\subsubsection{MIF - Inter-observer agreement}

The MIF test results were read by two independent observers. The two independent readings of both lgG- (Spearman's $P=0.873, P<0.001$ ) and $\lg A$ antibodies (Spearman's $P=0.860, P<0.001$ ) correlated adequately. The prevalence of seropositivity varied from approximately $85 \%$ to $12 \%$ for $\mathrm{lgG}$, and from approximately $70 \%$ to $4 \%$ for IgA, using different cut-off levels for $\mathrm{lgG}$ and IgA-seropositivity (Table 4.2). There were no structural differences in outcome between the two observers; i.e., observer 1 assigned higher titres to some sera, whereas observer 2 did so to some other samples. The degree of agreement (inter-observer agreement) when categories of serodiagnosis (seropositive or seronegative) using $1 / 32,1 / 64,1 / 128,1 / 256$ or $1 / 512$ as cut-off 
point for lgG-seropositivity, and using $1 / 8,1 / 16,1 / 32,1 / 64$ or $1 / 128$ as cut-off for $\lg A$-seropositivity, varied from $k=0.67$ to $k=0.80$ for $\operatorname{lgG}$, and from $k=0.62$ to $\kappa=0.85$ for $\lg A$ (Table 4.2 ).

Table 4.2 MIF: Interobserver agreement at various cutt-off levels for Chiamydia pnewmoniae seropositivity $(n=141)$

\begin{tabular}{|c|c|c|c|}
\hline \multirow[t]{2}{*}{ Cutt-off } & \multicolumn{2}{|c|}{$\%$ seropositivity } & \multirow[t]{2}{*}{ kappa } \\
\hline & Observer 1 & Observer 2 & \\
\hline $\lg G \geq 1 / 32$ & 84 & 87 & 0.80 \\
\hline $\lg G \geq 1 / 64$ & 73 & 77 & 0.74 \\
\hline $\lg G \geq 1 / 128$ & 55 & 61 & 0.75 \\
\hline $\lg G \geq 1 / 256$ & 32 & 38 & 0.71 \\
\hline $19 G \geq 1 / 512$ & 12 & 12 & 0.67 \\
\hline $\lg A \geq 1 / 8$ & 76 & 67 & 0.62 \\
\hline $\lg A \geq 1 / 16$ & 62 & 49 & 0.68 \\
\hline $\lg A \geq 1 / 32$ & 40 & 51 & 0.68 \\
\hline $\lg A \geq 1 / 64$ & 30 & 29 & 0.85 \\
\hline $\lg A \geq 1 / 128$ & 4 & 4 & 0.65 \\
\hline
\end{tabular}

\subsubsection{ElA - Intra-test agreement}

The IgG-and IgA-antibody titres of the first 44 patients were assayed by EIA in duplicate serum samples. Duplicate measurements showed (after logtransformation) an excellent correlation for both IgG- (Pearson's correlation coefficient: 0.989, $P<0.001$ ) and IgA-antibodies (Pearson's correlation coefficient: $0.973, P<0.001)$. Accordingly, the intra-test agreement of duplicate measurements comparing diagnostic categories (seropositive vs seronegative) at various cut-off levels was excellent for IgG and IgA (Table 4.3).

Table 4.3. EAl: Intratest agreement at various cut-off levels for Chlamydia pheumoniae seropositivity $(n=44)$

\begin{tabular}{|c|c|c|c|}
\hline \multirow[t]{2}{*}{ Cult-of } & \multicolumn{2}{|c|}{$\%$ seropositivity } & \multirow[t]{2}{*}{ kappa } \\
\hline & Sample 1 & Sample 2 & \\
\hline $196 \geq 1 / 32$ & 82 & 77 & 0.86 \\
\hline $\operatorname{lgG} \geq 1 / 64$ & 52 & 46 & 0.86 \\
\hline $\lg \mathrm{g} \geq 1 / 128$ & 25 & 20 & 0.87 \\
\hline $\lg G \geq \mathbb{1 2 5 6}$ & 0 & 0 & - \\
\hline $\operatorname{lgG} \geq 1 / 512$ & 0 & 0 & - \\
\hline $\lg A=1 / 8$ & 58 & 58 & 0.90 \\
\hline $\lg A \geq 1 / 16$ & 37 & 37 & 1.00 \\
\hline $\lg A \geq 1 / 32$ & 19 & 19 & 1.00 \\
\hline $\lg A \geq 1 / 64$ & 5 & 5 & 1.00 \\
\hline $\operatorname{lgA} \geq 1 / 128$ & 0 & 0 & - \\
\hline
\end{tabular}


Therefore, in the remaining 97 patients $\operatorname{lgG}$ - and IgA-antibody levels were determined in single serum samples. The Chlamydia pneumoniae seroprevalence varied from $79 \%$ to $0 \%$ for $\operatorname{lgG}$, and from $69 \%$ to $0 \%$ for $\lg A$, using increasing antibody levels as cut-off points for $\operatorname{lgG}$-and $\operatorname{lgA}$-seropositivity (Tables $4.4 \& 4.5$ ). Considering the lower sensitivity of the ElA, especially at the high titre range, sera with an IgG $\geq 64$ EIUs or IgA $\geq 16$ EIUs were retested at a higher pre-dilution (1/400). This resulted in higher seropositivity prevalences when elevated titres were used as cut-off (Tables $4.4 \& 4.5$ ).

Table 4.4 Comparing EIA to MIF test (gold standard). Intertest agreement (kappa), sensitivity, specificity, positive and negative predictive value of ElA for the detection of Chlamydia pheumoniae IgG seropositivity at various cut-off points $(n=141)$. Numbers in parentheses represent values calculated after retesting sera with IgG264 ElUs at higher pre-dilution.

\begin{tabular}{|c|c|c|c|c|c|c|}
\hline & \multicolumn{5}{|c|}{ Cut-off for lgG-seropasitivity at } \\
\hline & & $1 / 32$ & $1 / 64$ & $1 / 128$ & $1 / 256$ & $4 / 1512$ \\
\hline \multirow[t]{2}{*}{ \% seropositive } & MIF & 84 & 73 & 55 & 32 & 12 \\
\hline & EIA & 79 & 52 & $30(38)$ & $1(18)$ & $0(6)$ \\
\hline Kappa & & 0.70 & 0.43 & $0.40(0.54)$ & $0.03(0.46)$ & $-(0.25)$ \\
\hline Sensitivity & & 92 & 67 & $49(64)$ & $2(44)$ & $-(24)$ \\
\hline Specificity & & 87 & 87 & $91(92)$ & $100(95)$ & $-(96)$ \\
\hline PPV & & 97 & 93 & $88(91)$ & $100(80)$ & $-(44)$ \\
\hline NPV & & 67 & 49 & $60(68)$ & $69(78)$ & $-(90)$ \\
\hline
\end{tabular}

PPV: positive predictive value; NPV: negative predictive value.

\subsubsection{ElA vs MIF}

In the comparison of ElA vs. MiF, the EIA outcomes were weighed against the MIF readings of the same observer throughout all analyses. Of the titres determined by EIA in double serum samples in the first 44 patients, the first measurement was compared to the MIF. The titres of the remaining 97 were analysed in single serum samples by EIA and compared to the MIF results. When titres (in EIUs) calculated from the optical density readings obtained by the EIA were transformed into categorical variables corresponding to the MIF titre categories according to the transformation scheme given in Table 4.1, the correlation between EIA and MIF for both IgG and IgA was good (Spearman's $p=0.706, \quad P<0.001$, and Spearman's $p=0.745, \quad P<0.001$, for $\lg G$ and $\lg A$ respectively). Compared to the MIF, the EIA was less sensitive yielding lower prevalence of high antibody titres. Accordingly, the inter-test agreements between EIA and MIF in the detection of Chlamydia pneumoniae IgG- and IgAseropositivity, as well as, the sensitivity, specificity, PPV and NPV of EIA compared to MIF were dependent on the cut-off point used to determine seropositivity. As shown in Tables 4.4 and 4.5 , the ElA compared favourably to 
$8 6 \longdiv { \text { Ghapter } 4 }$

the MIF when seropositivity was defined at low cut-off points. However, the kappa values and sensitivity of the EIA decreased with increasing titre levels. For this reason, sera with $\lg G \geq 64$ EIUs or IgA $\geq 16$ ElULs were retested at a higher pre-dilution. This manoeuvre resulted in a slight improvement of the correlation between MIF and EIA for both IgG (Spearman's $P=0.730, P<0.001$ ) and IgA (Spearman's $P=0.762, P=0.001$ ), and in increased sensitivity of the $E I A$, yielding adequate intertest agreements when high titres were used to define Chlamydia pneumoniae seropositivity (Tables 4.4 and 4.5 ).

Table 4.5 Comparing EIA to MIF test (gold standard). Intertest agreement (kappa), sensitivity, specificity, positive and negative predictive value of EIA for the detection of Chlamydia pheumoniae lgA seropositivity at various cut-off points $(n=141)$. Numbers in parentheses represent values calculated after retesting sera with IgAz16 EIUs at higher pre-dilution.

\begin{tabular}{lrrrrrl}
\hline & \multicolumn{5}{c}{ Cut-off for lgA-seropositivity at } \\
\cline { 2 - 6 } & \multicolumn{1}{c}{$1 / 8$} & $1 / 16$ & $1 / 32$ & $1 / 64$ & $1 / 128$ \\
\hline \% seropositive & MIF & 76 & 62 & 40 & 30 & 4 \\
& EIA & 76 & 54 & $30(34)$ & $6(13)$ & $0(4)$ \\
Kappa & & 0.71 & 0.62 & $0.51(0.56)$ & $0.28(0.51)$ & $-(0.53)$ \\
Sensitivity & 93 & 78 & $60(67)$ & $21(44)$ & $-(44)$ \\
Specificity & 79 & 87 & $89(88)$ & $100(79)$ & $-(99)$ \\
PPV & 93 & 91 & $79(79)$ & $100(95)$ & $-(80)$ \\
NPV & 76 & 71 & $77(80)$ & $7581)$ & $-(99)$ \\
\hline
\end{tabular}

PPV: positive predictive value; NPV: negative predictive value.

\subsection{Discussion}

Since Saikku and his co-workers proposed an association between Chlamydia pneumoniae infection and coronary artery disease, ${ }^{4}$ the serological detection of Chlamydia pneumoniae infection has been of interest to a number of (cardiovascular) investigators. Various serological assays and different serological criteria for persistent or chronic active Chlamydia pneumoniae infection have been used so far in sero-epidemiological studies. This might partly explain the conflicting results of some of these reports. ${ }^{2}$ The development of a simple and technically accessible, objective test for the detection of Chlamydia pneumoniae antibodies is therefore mandatory.

The MIF test is commonly used to measure IgG-, $\lg A-$, and $\lg M$-antibodies to Chlamydia pneumoniae. It is considered both a sensitive and specific technique for the detection of Chlamydia pneumoniae infection ${ }^{5}$ and is nowadays regarded the gold standard for the detection of Chlamydia pneumoniae antibodies. ${ }^{6}$ However, the MIF test is labour intensive, requires an experienced reader and is hampered by the subjectivity of the outcome measure. In the present study, the MIF test was compared to the EIA, a technically less demanding alternative to the MIF, characterised by high 
throughput and an objective outcome measure. According to our results, in patients with cardiovascular disease the EIA test showed sufficient agreement with the MIF in the detection of Chlamydia pneumoniae antibodies, keeping in mind that the sensitivity of the EIA depends on the titre level. The seropositivity rate detected by the EIA was comparable to that obtained by the MIF when low cut-off levels for IgG- and IgA-seropositivity were used, but was lower compared to the MIF when high cut-off levels for IgG-and IgA-seropositivity were applied. In accordance, Numazaki et al reported an excellent correlation between MIF and ELISA in Japanese children although high Chlamydia pneumoniae antibody levels could only be detected with the MIF test. ${ }^{7}$ We were able to prevent this loss of sensitivity by retesting sera with elevated IgGand $\operatorname{lgA}$-titres at higher pre-dilutions. By this manoeuvre results could be obtained in the linear portion of the calibration curve, which resulted in increased agreement and sensitivity of EIA compared to the MIF at the high titre range.

Schumacher et al compared the Labsystems' MIF with the Labsystems" EIA and with Medac's rELISA (Hamburg, Germany) using sera of 197 patients with coronary heart disease and 197 age- and sex-matched controls. ${ }^{8}$ The rELISA, which detects antibodies against chlamydial LPS, did not correlate with MIF and EIA, both detecting mainly the surface exposed proteins of chlamydial elementary bodies. Although the authors concluded that the results of the EIA were significantly different from those of the MIF test, the reported agreement coefficient between the protein-immunoreactive MIF and EIA for detection of $\lg G$ - and $\lg A$-seropositivity (cut-offs $\lg G \geq 1 / 64$ and $\lg A \geq 1 / 32$ ) was $k=0.628$ and $\kappa=0.426$, respectively, which is satisfactory. ${ }^{9}$ Likewise, in a randomly selected group of 20 to 29 year old blood donors, the seroprevalence of $\lg A(\lg A \geq 1 / 8)$ was comparable when analysed by Labsystem's MIF and EIA. ${ }^{10}$

Although the agreement between EIA and MIF was satisfactory, the two tests did not yield the same outcome for all sera. Specimens that had been classified as seropositive by one test were seronegative by the other. Ideally the two serological assays should define the same sera as positive or negative according to the actual infectious status of the patient. Therefore, sera of true positive and true negative patients should have been included in the analysis. in this study we failed to comply with this requirement, as in case of patients with atherosclerotic disease, it is not known how to determine the (chronic) infectious status on the basis of serology. No correlation has been found between identification of Chlamydia pneumoniae in atherosclerotic tissue and Chlamydia pneumoniae antibodies. "Furthermore, no consensus has as yet been reached regarding the serological criteria for chronic or persistent Chlamydia pneumoniae infection. Various cut-off points for lgG-and $\lg A$ - titres or even $\operatorname{lgG}$ and $\operatorname{lgA}$ titre-combinations have been proposed. ${ }^{2}$ It remains, however, unclear whether the presence or titre of Chlamydia pneumoniae IgG- 
or IgA-antibody by MIF reflects persistent, chronic active infection or reinfection or may simply represent the immunological scar of past infection. ${ }^{12}$ For this reason, we limited our study to the evaluation of the agreement between the two serological assays using several antibody levels as cut-off for seropositivity.

Recent evidence suggests that the interlaboratory variation of the MIF is problematic. ${ }^{13}$ Taking into account that only minor antigenic differences have been found among the Chlamydia preumoniae strains used in the various (mostly in-house developed) MIF tests, this suggests that variation in reading of titres is probably the important factor for the variability in the MIF test results. In line herewith, the interobserver agreement of the MIF test in our study was good (Table 4.2) although the correlation between the independent readings was sub-optimal: In contrast, the intratest agreement of the EIA (Table 4.3) presented in this paper was excellent, which might reflect the advantages of the objective outcome measures.

The MIF is a species-specific assay for the detection of antibodies directed against surface expressed proteins of Chlamydia pneumoniae. The EIA has also been designed to detect Chlamydia pneumoniae surface expressed protein reactive antibodies, but is frustrated by cross-reacting antibodies in populations with a high background level of Chlamydia trachomatis antibodies. Nevertheless, in older populations with low incidence of Chlamydia trachomatis infection, for example individuals from western countries with cardiovascular disease such as the patients analyzed in the present study, no significant cross-reactivity is observed. ${ }^{14}$

In conclusion, our data suggest that, when measures are taken to obtain results in the linear portion of the detection curve, the EIA yields comparable results to the MIF. Considering the practical advantages of EIA testing and the fact that cardiovascular investigators with limited microbiological background and experience are involved in Chlamydia pneumoniae-related cardiovascular research, the use of EIA to detect Chlamydia pneumoniae antibodies might increase the external validity of future sero-epidemiological studies. 


\section{Pheummore serology. ElA ws. MIF}

\subsection{References}

1. Grayston JT. Does Chlamydia pneumoniae cause atherosclerosis? Arch Surg. 1999:134(9):930-4.

2. Siscovick DS, Schwartz SM, Caps M, Wang SP, Grayston JT. Chlamydia pneumoniae and atheroscleratic risk in populations: the role of seroepidemiology. I/nfect Dis. 2000:484 Suppl 3: $5417-20$.

3. Dowell SF, Peeling RW, Boman J, Carlone GM, Fields BS, Guamer J, at al Standardizing Chlamydia pneumoniae assays: recommendlations from the Centers for Disease Control and Prevention (USA) and the Laboratory Centre for Disease Control (Canada). Clin infect Dis. 2001;33(4):492-503.

4. Saikku $P$, Leinonen $M_{x}$ Mattila $K_{n}$ Ekman MR, Nieminen MS, Makela PH, et al. Serological evidence of an association of a novel Chlamydia, TWAR, with chronic coronary heart disease and acute myocardial infarction. Lancet. 1988;2(8618):983-6.

5. Grayston JT, Kuo CC, Wang SP, Altmar J. A new Chlamydia psittaci strain, TWAR, isolated in acute respiratory tract infections. N Eng/ IM Med. 1986;315(3):161-8.

6. Kauppinen $M$, Saikku P. Pneumonia due to Chlamydia pneumoniae: prevalence, clinical features, diagnosis, and treatment. Clin Infect Dis. 1995:21 Suppl 3:S244-52.

7. Numazaki $K$, Ikebe $T$, Chiba $S$. Detection of serum antibodies against Chiamydia pneumoniae by ELISA. FEMS /mmunol Med Microbial. 1996;14(2-3):179-83.

8. Schumacher $A$, Lerkerod $A B$, Seljeflot 1 , Sommervoll L, Holme I, Otterstad JE, at al. Chlamydia pneumoniae Serology: Importance of Methodology in Patients with Coronary Heart Disease and Healthy Individuals. I Clin Microbiol. 2001;39(5):1859-64.

9. Landis JR, Koch GG. The measurement of abserver agreement for categorical data. Biometrics, 1977;33(1):159-74.

10. Tuuminen $T$, Varjo $S$, Ingman $H$, Weber $T$, Oksi J, Viljanen M. Prevalence of Chlamydia pneumoniae and Mycoplasma pneumoniae immunoglobulin $G$ and $A$ antibodies in a healthy Finnish population as analyzed by quantitative enzyme immunoassays. Clin Diagn Lab Immunol. 2000;7(5):734-8.

11. Boman $J$, Hammerschlag MR. Chlamydia pneumoniae and Atherosclerosis: Critical Assessment of Diagnostic Methodls and Relevance to Treatment Studies. Clin Microbiol Rev. $2002 ; 15(1): 1-20$.

12. Tuuminen $T$, Palomaki $P$, Paavonen $J$. The use of serologic tests for the diagnosis of chlamydial infections. J Microbiol Methods. 2000;42(3):265-79.

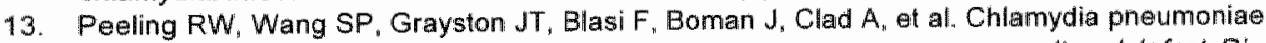
serology: interlaboratory variation in microimmunofluorescence assay results. If lafect Dis. $2000 ; 181$ Suppl $3:$ S426-9.

14. Gnarpe J. Naas J. Lundback A. Comparison of a new commercial EIA kit and the microimmunofluorescence technique for the determination of $\operatorname{lgG}$ and $\lg A$ antibodies to Chlamydia pneumoniae. Apmis. 2000;108(1.2):819-24. 
90 


\section{Chapter 5}

Chlamydia pneumoniae in atherosclerotic

disease: evaluating the association between

serum antibodies and presence of antigens or

DNA in vascular tissue

Vainas T, Stassen FR, Kurvers HA, Grauls GE, Bruggeman CA, Kitslaar PJ Submitted 


\subsection{Abstract}

\section{Background}

Despite the large number of studies assessing the role of Chlamydia pneumonia in atherosclerotic disease, no consensus about the serological detection of clinically relevant (vascular) Chlamydia pneumoniae infection has been reached yet. The aim of this study was to identify serological criteria for the detection of Chlamydia pneumoniae in the vascular wall, and to study the relationship between signs of Chlamydia pneumoniae infection (i.e., serum antibodies or presence of Chlamydia pneumoniae particles in the vascular wall) and atherosclerotic plaque morphology.

\section{Patients \& methods}

Chlamydia prieumoniae IgG- and IgA-antibodies were measured in the serum of 127 patients undergoing reconstruction surgery for severe atherosclerotic disease. Chramydia oneumoniae DNA or antigens were detected in vascular tissue by PCR or immunohistochemistry, respectively. Receiver Operating Characteristic (ROC) curves were computed to study the association between Chlamydia pneumoniae serology and vascular presence of Chlamydia pneumoniae. Furthermore, the relation between plaque morphology and signs of Chlamydia pneumoniae infection (antibodies or vascular Ch/amydia pneumoniae presence) was analysed.

\section{Results}

Chlamydia pneumoniae serum antibodies were frequently found. Chlamydia pneumoniae antigens were detected in approximately $60 \%$ of plaques although Chlamydia pneumoniae DNA was seen in only $9 \%$ of them. No association between serology and vascular presence of Chlamyrdia pneumoniae was found. The sensitivity and specificity of serology for detection of vascular Chlamydia pneumoniae was poor. No association could be found between signs of infection (serological or histological) and piaque morphology.

\section{Conclusion}

Although antibodies are frequently found in patients with cardiovascular disease, and Chlamydia pneumoniae particles can be detected in a significant number of plaques, only a poor association between Chlamydia pneumoniae serology and its vascular presence was found rendering Chlamydia pneumoniae serology not suitable for the detection of patients with relevant vascular infection. Additionally, plaque morphology is not related to Chlamydia pneumoniae serology or vasicular presence. 


\subsection{Introduction}

In recent years it has been shown that Chlamydia pneumoniae seropositivity is associated with acute and chronic atherosclerotic complications. ${ }^{1}$ Moreover, it has become evident that atherosclerotic lesions harbour chlamydial DNA and antigens. ${ }^{1.2}$ Hence, it is believed that vascular Chlamydia pneumoniae infections, especially chronic active or persistent rather that acute ones, are associated with the development of atherosclerosis. ${ }^{3}$ However, the serological criteria for chronic active or persistent vascular Chlamydia pneumoniae infections have not yet been established conclusively. ${ }^{4}$ Therefore, in the present study we assessed the presence of either chlamydial antigens (i.e. major outer membrane proteins (MOMP) and heat shock protein 60 (HSP60)) by immunohistochemistry $(I H C)$, or chlamydial DNA by polymerase chain reaction (PCR) in vascular tissue of patients undergoing reconstructive surgery of the carotid artery, aorta or lower limb arteries for severe atherosclerotic disease. In the same patients the Chlamydia pneumoniae antibodies were measured to reveal a possible association between the prevalence of either chlamydial antigens or DNA in vascular tissue and Chlamydia pneumoniae antibody titres, thereby determining the serological criteria that would most securely identify patients potentially harbouring a vascular Chlamydia pneumoniae infection.

Ch/amydia pneumoniae infection has been linked to atherosclerotic disease mainly on the basis of sero-epidemiological studies, showing on numerous occasions an association between elevated levels of Chlamydia pneumoniae antibodies and cardiovascular disease. ${ }^{1}$ However, it is not clear whether the presence of Chlamydia pneumoniae in vascular tissue is associated with atherosclerotic plaque morphology, or even with clinical manifestation of atherosclerotic disease. For this reason, we also studied the relation between plaque morphology, assessed according to the American Heart Association classification criteria, and (i) presence of Chlamydia pneumoniae antigens in the vascular tissue or (ii) Chlamydia pneumoniae serology.

\subsection{Materials and methods}

Vascular tissue and preoperatively drawn blood of 127 patients undergoing vascular reconstructions of the aorta, carotid, or lower limb arteries were collected. The study subjects represented a random subpopulation of vascular surgical patients treated at the vascular surgical clinic of Maastricht University Hospital. All patients undergoing vascular reconstruction surgery for atherosclerotic disease, whose serum and atherosclerotic tissue was available 
for analysis, qualified for entry to the study, provided that they gave written informed consent.

Vascular tissue of the first 70 patients was fixed in formalin and embedded in paraffin for immunohistochemical detection of Chlamydia pneumoniae antigens. Arterial samples of the following 57 patients were snap frozen in hiquid nitrogen for detection of Chlamydia pneumoniae DNA by PCR. Chlamydia pneumoniae lgA and $\lg \mathrm{G}$ antibody titres were determined in all 127 patients. The study was approved by the local medical ethical committee.

\subsubsection{Chlamydia pneumoniae antibody detection}

Preoperatively collected blood was centrifuged at 1200 rpm for 10 minutes to obtain serum that was stored at $-20^{\circ} \mathrm{C}$ until analysis. Chlamydia pneumoniae IgG- and IgA-antibodies were measured by means of a Chlamydia pneumoniae specific enzyme immunoassay (Labsystems, Helsinki, Finland) according to the manufacturer's instructions ${ }^{5}$ and as described earlier. ${ }^{6}$ In short, serum diluted at 1/100 was incubated with Chlamydia pneumoniae antigens coated onto a 96-wells plate. Anti-immunoglobuline ( $\lg G$ or $\operatorname{lgA}$ ) conjugated with horseradish peroxidase was added to the wells after washing, and incubated for $60 \mathrm{~min}$ at room temperature. Subsequently the chromogen containing tetramethylbenzidine was added to the wells after washing. The reaction was stopped with sulphuric acid after $30 \mathrm{~min}$ and optical density was immediately read at $450 \mathrm{~nm}$. Antibody titres were calculated from optical density readings according to manufacturer's instructions. Results are given in mean Enzyme Immunounits (EIU) \pm Standard deviation (SD). According to the manufacturer, the enzyme immunoassay is titrated in such a way that the EIU-value calculated from the optical density readings corresponded to the reciprocal value of the titre determined by the micro-immunofluoresence of the same manufacturer (Table 5.1). Although this method may not be the "gold standard" we previously demonstrated that the EIA yields comparable results to the MIF in patients with cardiovascular disease.

Tabile 5.1 Transforming Chlamydia pneumoniae antibody titre calculated with the EIA (in ElUs) into MIF-titire categories.

\begin{tabular}{|c|c|c|c|}
\hline \multicolumn{2}{|r|}{$\lg G$} & \multicolumn{2}{|r|}{$\lg A$} \\
\hline ElA titre (EUU) & Corresponding MIF-titre & ElA titre (EUU): & Corresponding MIF-titre \\
\hline $\lg G<32$ & 0 & $\lg A<8$ & 0 \\
\hline $32 \leq \lg G<64$ & $1 / 32$ & $8 \leq \lg A<16$ & $1 / 8$ \\
\hline $64 \leq \lg G<128$ & $1 / 64$ & $16 \leq \lg A<32$ & $1 / 16$ \\
\hline $128 \leq 19 G<256$ & $1 / 128$ & $32 \leq \lg A<64$ & $1 / 32$ \\
\hline $256 \leq \lg G<512$ & $1 / 256$ & $64 \leq \lg A<128$ & $1 / 64$ \\
\hline $\operatorname{lgG} \geq 512$ & $1 / 512$ & $\lg A \geq 128$ & $1 / 128$ \\
\hline
\end{tabular}




\subsubsection{Vascular tissue and plaque morphology}

Atherosclerotic plaques obtained during operation of the first 70 patients were fixed in formol and embedded in paraffin for determination of plaque morphology and for immunohistochemical detection of Chlamydia pneumoniae proteins. Vascular tissue from the following 57 patients was snap frozen in liquid nitrogen for detection of Chlamydia pneumoniae DNA.

Plaque morphology was assessed in one hematoxylin-eosine stained section per patient, according to the Stary classification system of atherosclerotic tissue. ${ }^{7.8}$ A plaque was characterized unstable in the presence of intra-plaque hemorrhage, fibrous cap rupture or presence of organized luminal thrombus.

\subsubsection{Immunohistochemistry}

For this purpose, deparaffined serial sections were incubated with two monoclonal Chlamydia pneumoniae-antibodies, i.e., (i) an antibody directed against Chlamydia pneumoniae MOMP (RR-402, DakoCytomation, Glostrup, Denmark) and (ii) an monoclonal antibody directed against Chlamydial HSP60 (ABR-Affinity BioReagents Inc, Golden, Colorado, USA). Normal mouse ascitic fluid was used as negative antibody control. Subsequently, incubation with a rabbit anti mouse antibody (DakoCytomation) and streptavidine biotine complex (DakoCytomation) was performed in a multi-step immunostaining procedure. The coloric reaction was created with diaminobenzidine. Chlamydia pneumoniae-infected and non infected human epithelial cells were used as positive and negative tissue controls in each run. According to the recommendations of a consensus committee, a cell was classified as Chlamydia pneumoniae-positive if it showed smooth or granular cytoplasmic staining whereas the same cell on the subsequent section incubated with mouse ascitic fluid stained negative. ${ }^{4}$

\subsubsection{Chlamydia pneumoniae PCR}

Chlamydia pneumoniae DNA fragments were detected by means of a 'touchdown' PCR. ${ }^{9}$ DNA was extracted from atheroma by conventional proteinase K digestion (Qiagen Genomics Inc, Bothell, Washington, USA). The primer pair used amplified a 207 bp species-specific target sequence from the major outer membrane protein gene of Chlamydia pneumoniae. ${ }^{10}$ DNA extraction, PCR amplification and electrophoresis were performed in separate rooms in order to minimize the risk of contamination. 


\subsubsection{Statistical analysis}

Receiver-operating characteristic (ROC) curves were computed in order to evaluate the ability of $\mathrm{lgG} / \mathrm{lgA}$ antibody titres to detect presence of Chlamydia pneumoniae antigens or DNA in vascular tissue. Mean Chlamydia pneumoniae antibody titres between patients with stable vs. unstable plaques were compared with the Mann-Whitney $U$ test. The association between the presence of Chlamydia pneumoniae in the plaque and plaque morphology was analysed with the $\chi^{2}$-test: Pearson's $r$ was computed to study the correlation between MOMP and HSP60 immunoreactivity. All analyses were done on a SPSS 10.0 software package for windows (SPSS Inc., Chicago, Illinois).

\subsection{Results}

\subsubsection{Patients}

Data of 127 patients operated in a single teaching hospital were analysed. Entry criteria were the existence of atherosclerotic occlusive or aneurysmal disease and the avallability of, both, serum and vascular tissue for analysis. Patient characteristics are given in Table 5.2.

Table 5.2 Patient characteristics

\begin{tabular}{lc}
\hline N & 127 \\
\hline Mean (SD) age in years & $66.9(8.5)$ \\
Male/female $^{*}$ & $100 / 27$ \\
Diabetes Melitus $^{\theta}$ & $24(19)$ \\
Dislipidemia $^{\circ}$ & $89(70)$ \\
Hypertension $^{c}$ & $89(70)$ \\
Smoking $^{\circ}$ & $88(69)$ \\
Carotid surgery $_{\text {Aartic surgery }}$ & $40(31)$ \\
Femorodistal surgery & $24(19)$ \\
\hline
\end{tabular}

Values representt number (percentage) of patients.

"Fasting glucose level $>7 \mathrm{mmol} / \mathrm{l}$ or the use of antiglycemic medication or insulin; "Fasting medication; "Systolic blood pressure $>160 \mathrm{mmH}$ level $>1.95 \mathrm{mmol} / \mathrm{l}$ and/or use of antilipemic use of antihypertensive medication.

\section{4 .2 Chlamydia pneumoniae serology}

Table 5.3 gives the mean (SD) $\lg G$ - and $\operatorname{lgA}$-titre in EIUs as well as the percentage IgG- and IgA-seropositive patients using various cut-off levels for seropositivity. Evidently. Chiamydia pneumoniae IgG-and IgA-antibodies are 
frequently found in patients with atherosclerotic disease of the carotid, aortic or femorodistal arterial segment.

Table 5.3 Mean Chlamydia pneumoniae $\lg A$ - and $\lg G$ antibody titres (in ElU) and Chramydia pneumoniae IgA- and IgG-seropositivity at various cut-off levels.

\begin{tabular}{|c|c|c|c|}
\hline Immunoglobuline & Cut-off & Seropositive & Mean (SD) in EIUs \\
\hline $\lg A$ & & & $26(22)$ \\
\hline & $\lg A \geq 8$ & $97(76)$ & \\
\hline & $\lg A \geq 16$ & $69(54)$ & \\
\hline & $\lg A \geq 32$ & $40(31)$ & \\
\hline & $\lg A \geq 64$ & $13(10)$ & \\
\hline & $\lg A \geq 128$ & $0(0)$ & \\
\hline \multirow[t]{7}{*}{$\lg G$} & & & $108(94)$ \\
\hline & $\lg G \geq 16$ & $116(91)$ & \\
\hline & $\lg G \geq 32$ & $104(82)$ & \\
\hline & $\lg G \geq 64$ & $78(61)$ & \\
\hline & $\| \mathrm{gG} \geq 128$ & $44(35)$ & \\
\hline & $\lg G \geq 256$ & $5(4)$ & \\
\hline & $\lg G \geq 512$ & $2(2)$ & \\
\hline
\end{tabular}

EIU: Enzyme Immuno-unit

values represient number (percentage) of seropositive patients at various cut-off levels

\subsubsection{Evidence of vascular Chlamydia pneumoniae infection}

The presence of Chlamydia pneumoniae antigens in atheromatous tissue of 70 patients was assessed by means of immunohistochemical detection using two monoclonal antibodies, directed against (i) MOMP and (ii) HSP60. Thirty-one plaques $(44 \%)$ stained positive for both antigens, 9 plaques $(13 \%)$ stained positive for MOMP only, and 11 plaques $(16 \%)$ were Chlamydia pneumoniae HSP60 positive only. The 2 stainings correlated significantly with each other ( $r=0.412, p<0.0001$ ).

The presence of Chlamydia pneumoniae DNA was assessed in 57 patients. Of these 57 plaques, $5(9 \%)$ were Chlamydia pneumoniae DNA-positive.

\subsubsection{Detecting vascular Chamydia pneumoniae infection by means of Chlamydia pneumoniae serology}

We further examined the correlation between Chlamydia pneumoniae serology and vascular presence of Chlamydia pneumoniae-antigens or Chlamydia pneumoniae DNA. Figure 5.1 shows the receiver operating characteristics of Chlamydia pneumoniae IgG- and IgA-titres for detection of vascular Chlamydia pneumoniae antigens (MOMP+ and/or HSP60+) or Chlamydia pneumoniae DNA. As shown, the sensitivity and specificity of Chlamydia pneumoniae serology for the detection of vascular Chlamydia pneumoniae infection was 
poor, as the area under the curve did not exceed 0.565 in any case. Therefore, regardless of the cut-off point for positive serology, no significant association existed between Chlamydia pneumoniae seropositivity and vascular presence of either Chlamydia pneumoniae antigens or DNA, indicating that the presence of serum Chlamydia pneumoniae Ig's is in neither way indicative for a chronic or persistent vascular Chlamydia pneumoniae infection.
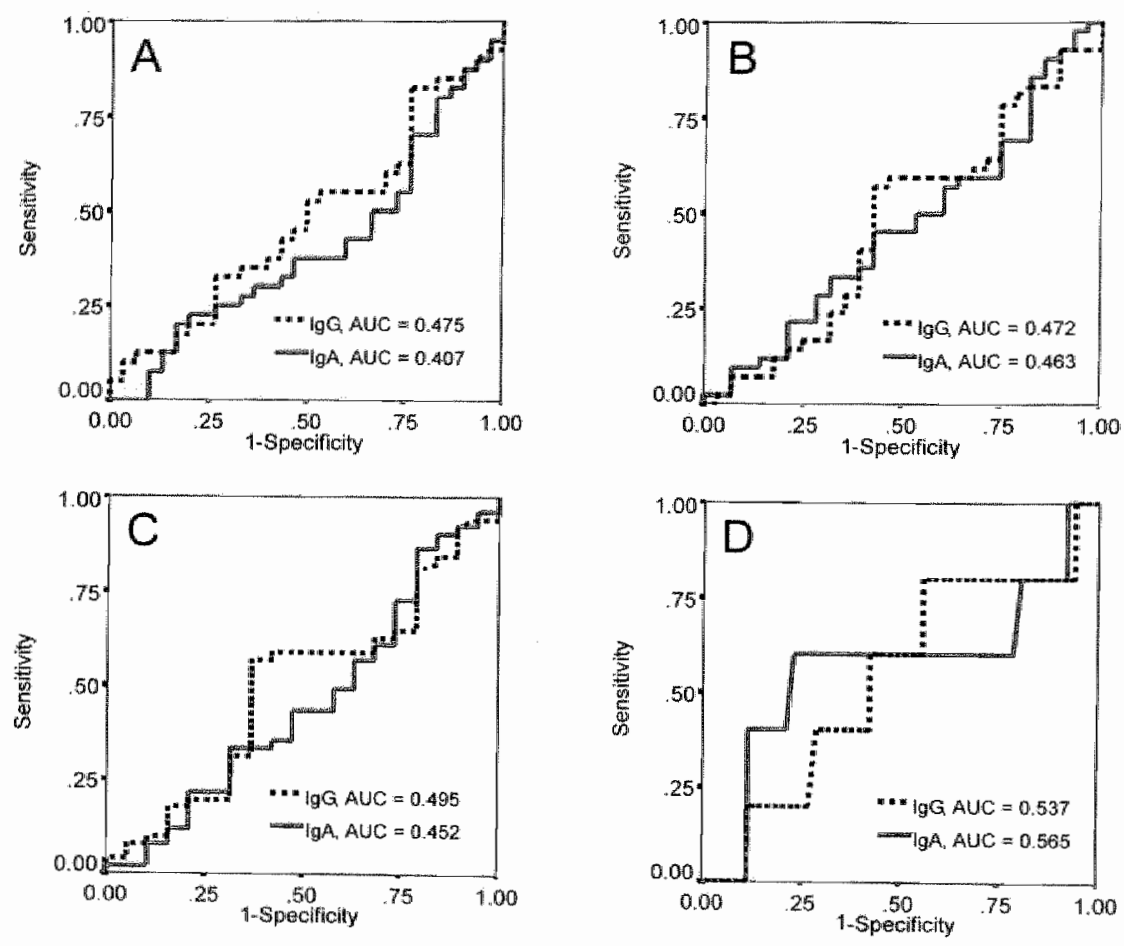

Figure 5.1 Sensitivity and specificity of Chlamydia pneumoniae serology for detection of vascular Chlamydia pneumoniae antigens/DNA.

ROC curves demonstrating the sensitivity and specificity of Chlamydia pneumoniae IgG- and IgA-antibodies for the detection of vascular presence of (A) Chlamydia pneumoniae MOMP, (B) Chlamydia pneumoniae HSP60, (C) Chlamydia pneumoniae antigens (MOMP and/or HSP60), (D) Chlamydia pneumoniae DNA.

AUC $=$ Area Under Curve.

\subsubsection{Plaque (in)stability and Chlamydia pneumoniae infection}

Plaque instability defined as the presence of organised thrombus, fibrous cap rupture and/or intraplaque haemorrhage was present in $37 / 70(53 \%)$ plaques. Plaque instability was not related to presence of Chlamydia pneumoniae 
antigens (MOMP and/or HSP60) in vascular tissue ( $P=n s, \chi^{2}$-test). Neither was the IgG- and IgA-titre (in EIUs) significantly different between patients with stable versus patients with unstable plaques ( $P=n s$, Mann-Whitney $U$ test).

\subsection{Discussion}

Ever since Saikku et $a l^{11}$ showed that coronary artery disease is associated with elevated Chlamydia pneumoniae antibody titres, numerous studies have explored the association between Chlamydia pneumoniae infection and the development of atherosclerosis determining Chlamydia pneumoniae antibodies in patients with coronary, carotid, aortic and peripheral arterial disease. Despite a mixture of studies confirming this original observation, the significance of these data has been questioned, as the pooled risk estimate for the relation between Chlamydia pneumoniae and atherosclerosis did not support the suggested association between infection and atherosclerotic disease. ${ }^{12-14}$ Nevertheless, a recent meta-analysis including studies published between January 1997 and December 2000 showed that seropositivity is related to atherosclerosis with a pooled odds ratio of $1.6(95 \%$ confidence interval: $1.3-2.0$ ). The authors suggested that study design (cross sectional vs. nested case control studies) as well as duration of follow-up in the prospective studies was a source of variability. ${ }^{15}$

Many pro-atherogenic effects of Chlamydia pneumoniae on various components of the vascular wall have been reported. ${ }^{46}$ This implies that the presence of the pathogen in the vessel wall might be a prerequisite for exerting atherogenic effects and therefore depends on a chronic active or persistent Chlamydia pneumoniae infection of the artery. Indeed, both Chlamydia pneumoniae antigens or DNA have been demonstrated in vascular specimens, obtained from patients undergoing vascular reconstruction. ${ }^{17}$ Also, in their extensive meta-analysis Gutierrez and colleagues ${ }^{14}$ demonstrated the strongest association between Chlamydia pneumoniae and atherosclerosis in immunohistochemical $(O R=15.4)$ and (nested) PCR studies of arterial and nonarterial material ( $O R=4.3$ and 16.7, respectively), suggesting that it would be most useful to analyse the presence of the pathogen in arterial as well as nonvascular biopsies to identify patients with Chlamydia pneumoniae as potential risk factor. Due to ethical and practical constrains it might virtually be impossible to obtain vascular tissue for diagnostic purposes. In contrast, serum samples may readily be available for determination of Chlamydia pneumoniae antibody titres. Assuming that the presence of Chlamydia pneumoniae in the vascular wall is indicative for future cardiovascular complications, it might be of diagnostic use if serum antibody titres would closely correlate to the presence of Chlamydia pneumoniae in vascular tissue. In the present study we explored the association between Chlamydia pneumoniae antibodies and the presence 
of Chlamydia pneumoniae antigens or DNA in the vessel wall attempting to identify an appropriate serological marker of potential vascular Ch/amydia pneumoniae infection.

Our results indicate that Chlamydia pneumoniae $\mathrm{lgG}$ - and $\operatorname{lgA}$-antibodies are poorly associated with the presence of Chlamydia pneumoniae antigens or DNA in atherosclerotic vessel wall, detected by immunohistochemistry (IHC) or by means of PCR, suggesting that measurement of serum antibody titres is inadequate to detect patients with vascular Chlamydia pneumoniae infections. Despite the fact that Blasi ef al. had shown that Chlamydia pneumoniae seropositivity (defined as $16 \leq \lg G<512$ and/or $32 \leq \lg A<256$ ) was significantly higher in subject with Chlamydia pneumoniae PCR-positive plaques than in subjects with PCR-negative plaques, ${ }^{18}$ several investigators found, in agreement with our data, no association between Chlamydia pneumoniae serology and detection of Chlamydia pneumoniae in vascular tissue by PCR and/or culture. ${ }^{19-21}$ However, in these studies, the relation between Ch/amyolia pneumoniae serology and presence of Chlamydia pneumoniae in vascular tissue, was analysed using a single cut-off point for seropositivity (lgG $\geq 1 / 8$ or $\lg G \geq 1 / 16$ ), despite the fact that no uniform criteria for the serological detection of chronic active or persistent chlamydia pneumoniae infection have been formulated yet." Measuring Chlamydia pneumoniae titres as a continuous variable with an EIA and applying ROC analysis, we essentially tested for an association between seropositivity and vascular presence of Ch/amydia pneumoniae using virtually every single titre value as cut-off point for seropositivity bypassing the limitation of previous studies exploring the association between vascular Chlamydia pneumoniae and seropositivity defined by a single (not standardised) cut-off point. Nevertheless, even this more extensive approach did not reveal any correlation between Chlamydia pneumoniae serology and the presence of Chlamydia pneumoniae in vascular tissue.

Both IHC and PCR techniques have been applied to demonstrate the presence of Chlamydia pheumoniae in vascular tissue and both Chlamydia pneumoniae antigens as well as Chlamydia pneumoniae DNA could be demonstrated. " However, results were not always consistent and discrepancies have previously been reported. A similar discordance was found in the present study. While almost $50 \%$ of all samples examined stained positive for both antigens (MOMP and HSP60), Chlamydia pneumoniae DNA could only be detected in $9 \%$ of all samples examined. Meijer et al. suggested that this might be related to differences in kinetics of degradation of the various Chlamydia pneumoniae components, with rapid degradation of Chlamydia pneumoniae DNA and HSP60 and persistence of the membrane proteins. ${ }^{22}$ However, this is not confirmed by the present data as the number of MOMP or HPS60 positive specimens was not different. Alternatively, Hoymans and colleagues ${ }^{23}$ recently 
demonstrated that the high percentage of immunohistochemical $(I \mathrm{HC})$ positive samples might be due to cross-reaction of the antibodies used with nonchllamydial plaque constituents like autofluorescent ceriod deposits. ${ }^{22}$ This may explain the repeatedly demonstrated discrepancies between PCR data and $\mathbb{I H C}$ assays. Unfortunately, due to logistic reasons we were not able to cross-test specimens by both methods. The disagreement between $\mathrm{HHC}$ and PCR may be related to the fact that the overall performance of IHC and PCR to detect vascular Chlamydia pneumoniae infection is poor. The sensitivity and specificity of these assays is far from optimal keeping in mind the reported differences in Chlamydia pheumoniae detection rate, varying between 0 and $100 \%{ }^{24.25}$ It may also represent a sampling error as in most cases only a limited amount of vascular tissue has been assayed. Cochrane et al. showed that the detection rate of Chlamydia pneumoniae DNA in carotid atheroma increased from $39 \%$ to $100 \%$ when $1,2,5,10,15$ and 20 sections per carotid atheroma were analysed. ${ }^{26}$ Assuming that the presence of Chlamydia pneumoniae in vascular tissue is indeed $100 \%$ if tested thoroughly, the sensitivity and specificity of Chlamydia pneumoniae serology for the detection of presence of vascular Chlamydia pneumoniae would still remain very poor (data not shown). Hence, detection of Chlamydia pneumoniae antigens or DNA in vascular tissue is hampered by methodological pitfalls and is probably by the currently available techniques not pathognomonic for the presence of Chlamydia pneumoniae in vascular tissue.

Earlier sero-epidemiological studies suggested that Chlamydia pneumoniae infections have pro-atherogenic properties, since elevated Chlamydia pneumoniae antibodies are associated with the development of acute and chronic atherosclerosis-related cardiovascular events. ${ }^{1}$. Animal studies support the notion that Chlamydia pneumoniae infections stimulate atherogenesis ${ }^{27,28}$ and in vitro evidence suggests ${ }^{29-31}$ that this might be due to locally induced pro-atherogenic changes in the vessel wall. Yet, the data presented here and elsewhere ${ }^{32,33}$ failed to show any association between vascular presence of chlamydia pneumoniae antigens or DNA and plaque morphology. This suggests that in humans, vascular Chlamydia pneumoniae infection may not stimulate advanced atherosclerotic lesion progression or transformation of an advanced stable plaque into an unstable one through in situ processes. In contrast, the association between Chlamydia pneumoniae and atherosclerosis might be mediated by the systemic effects of (non)vascular Chlamydia pneumoniae infection and/or by the host response to Chlamydia pneumoniae infection. We have shown in this respect that Chlamydia pneumoniae infection is associated with hypercoagulability but not with plaque morphology in patients with carotid artery disease ${ }^{34}$ In addition, plasma fibrinogen levels are elevated in patients with Chlamydia pneumoniae infections ${ }^{35}$ and decrease upon antimicrobiall treatment. ${ }^{36}$ Chlamydia pneumoniae infection might also contribute to 
the development of atherosclerosis through stimulation of cytokine production ${ }^{37}$ and through alteration of lipid metabolism. ${ }^{38,39}$ Furthermore, it has been shown that antibodies elicited against chlamydial HSP60 cross-react with human autologous HSP60 and can cause lysis of stressed endothelial cells expressing on their surface human HSP60..$^{40}$ In other words, although in vitro studies suggest that infection of vascular cells with Chlamydia pneumoniae is associated with atherosclerosis progression, the lack of an association between the presence of Chlamydia pneumoniae antigens and DNA in vessel wall and atherosclerotic plaque morphology, suggests that in humans systemic rather than local effects of Chlamydia pneumoniae infection such as stimulation of hypercoagulability and cytokine production or induction of an auto-immune response might have clinically significant pro-atherogenic properties.

In conclusion, the present data suggest that Chlamydia pneumoniae serology is not suitable to detect vascular presence of Chlamydia pneumoniae antigens or DNA. Moreover, Chlamydia pneumoniae infection does not seem to be associated with plaque morphology. The lack of association between Chlamydia pneumoniae infection (determined by serology or the detection of antigens/DNA in vascular tissue) and plaque morphology, suggests in the light of the suggested association between Chlamydia pneumoniae serology and atherosclerotic events, that in humans, Chlamydia pneumoniae infection might stimulate atherogenesis not via direct effects on components of the vascular wall but more likely through the induction of systemic atherothrombotic phenomena. 


\subsection{References}

1. Leinonen $M$, Saikku P. Evidence for infectious agents in cardiovascular disease and atherosclerosis. Lancet infect Dis. 2002;2:11-7.

2. Grayston JT. Background and current knowledge of Chlamydia pneumoniae and atherosclerosis. I Infect Dis. 2000;181 Suppl 3:S402-10.

3. Saikku $P$, Leinonen $M$, Tenkanen $L_{\text {" }}$ Linnanmaki $E_{\text {。 }}$ Ekman $M R_{\text {, Manninen }} V_{\text {, Manttari }} M_{\text {v }}$ Frick $\mathrm{MH}$, Huttunen JK. Chronic Chlamydia pneumoniae infection as a risk factor for coronary heant disease in the Helsinki Heart Study [see comments]. Ann Intern Med 1992;116:273-8.

4. Dowell SF, Peeling RW, Boman J, Carlone GM, Fields BS, Guarner J, Hammerschlag MR: Jackson LA, Kuo CC, Maass $M$, Messmer TO, Talkington DF, Tondella ML, Zaki SR. Standardizing Chlamydia pneumoniae assays: recommendations from the Centers for Disease Control and Prevention (USA) and the Laboratory Centre for Disease Control (Canada). Cim Infect Dis 2001;33:492-503.

5. Tuuminen $T$, Varjo $S$, Ingman $H$, Weber $T$, Oksi $J_{2}$ Viljanen $M$. Prevalence of Chlamydia pneumoniae and Mycoplasma pneumoniae immunoglobulin $G$ and $A$ antibodies in a healthy Finnish population as analyzed by quantitative enzyme immunoassays. Clin Diagn Lab immunol. 2000;7:734-8.

6. Vainas $T$, de Graaf $R$, Stassen FR, Kurvers HA, Grawils GE, Kitslaar PJ Bruggeman CA. Chlamydia pneumoniae serology: comparing a commercial enzyme immunoassay and microimmunofluorescence test in patients with cardiovascular disease. APMIS. 2003,111:363-9.

7. Stary $H C$, Chandler $A B$, Dinsmore RE, Fuster $V$, Glagov $S$, Insull $W$, Jr, Rosenfeld $M E_{\text {, }}$ Schwartz Cd, Wagner WD, Wissler RW. A definition of advanced types af atherosclerotic lesions and a histological classification of atherosclerosis. A report from the Committee on Vascular Lesions of the Council on Arteriosclerosis, American Heart Association. Arterioscler Thromb Vasc Biol. 1995;15:1512-31

8. Stary $H C$, Chandler $A B$, Glagov $S$, Guyton JR, insull $W$, Jr., Rosenfeld ME, Schaffer SA, Schwartz $C J$, Wagner WD, Wissler RW. A definition of initial, fatty streak, and intermediate lesions of atherosclerosis. A report from the Committee on Vascular Lesions of the Council on Arteriosclerosis, American Heart Association. Circulation. 1994:89:2462-78.

9. Don RH, Cox PT, Wainwright BJ, Baker K, Mattick JS. 'Touchdown' PCR to circumvent spurious priming during gene amplification. Nucleic Acids Res. 1991;19:4008.

10. Tong $C Y$, Sillis $M$. Detection of Chlamydia pneumoniae and Chlamydia psittaci in sputum samples by PCR. J Clin Pathol 1993;46:343-7.

11. Saikku $P$, Leinonen $M$, Mattila $K$, Ekman MR, Nieminen MS, Makela $\mathrm{PH}_{i}$ Huttunen JK, Valtonen $V$. Serological evidence of an assaciation of a novel Chlamydia, TWAR, with chronic coronary heart disease and acute myocardial infarction. Lancet. 1988;2:983-6.

12. Danesh J, Whincup P, Walker M, Lennon L, Thomson A, Appleby P. Wong $Y_{x}$ BernardesSilva $M$, Ward $M$. Chlamydia pneumoniae IgG titres and coronary heart disease: prospective study and meta-analysis. BMJ. 2000;321:208-13.

13. Danesh $J$, Whincup $P$, Lewington $S$, Walker $M$, Lennon $L$, Thomson $A$, Wong $Y K_{\text {, }} Z$ Zhou $X_{\text {, }}$ Ward M. Chlamydia pneumoniae IgA titres and coronary heart disease; prospective study and meta-analysis. Eur Heart $J$ 2002;23:371-5.

14. Gutierrez J, de Dios Luna J, Linares $J$, del Rosario Montes M, Quesada E, Rojas A, Soto MJ, Sorlozano A. Relationship between peripheral arterial occlusive disease (PAOD) and chronic Chlamydophila (Chlamydia) pneumoniae infection. A meta-analysis Thromb Haemost. 2005;93:1153-60.

15. Bloemenkamp DG, Mali WP. Visseren FL, van der Graaf $Y$. Meta-analysis of seroepidemiologic studies of the relation between Chlamydia pneumoniae and atherosclerosis: does study design influence results? Am Heart J 2003;145:409-17.

16. Kalayoglu MV, Libby $P$, Byrne Gl. Chlamydia pneumoniae as an emerging risk factor in cardiovascular disease. JAMA. 2002,288:2724-31. 
17. Kuo C. Campbell LA. Detection of Chlamydia pneumoniae in arterial tissules. I Infect Dis. 2000;181 Suppl 3:S432-6.

18. Blasi F, Denti F, Erba M, Cosentini R, Raccanelli R, Rinaldi A, Fagetti L, Esposito G, Ruberti $U$. Allegra L. Detection of Chlamydia pneumoniae but not Helicobacter pylori in atherosclerotic plaques of aortic aneurysms. J Clin Microbiol. 1996:34:2766-9.

19. Bartels $C$, Maass $M_{n}$ Bein $G$, Brill $N$, Bechtel JF, Leyh R, Sievers HH. Association of serology with the endovascular presence of Chlamydia pneumoniae and cytomeglalovirus in coronary artery and vein graft disease. Circulation 2000;101:137-41.

20. Maass M. Gieffers J, Krause E, Engel PM, Bartels $C_{n}$ Solbach W. Poor correlation between microimmunofluorescence serology and polymerase chain reaction for detection of vascular Chlamydia pneumoniae infection in coronary artery disease patients. Med Microbiol Immunol (Berl). 1998;187:103-6.

21. Porqueddu $M$, Spirito $R$, Parolari $A$, Zanobini $M$, Pompilio $G$, Polvani $G$, Alamanni $F$; Stangalini $D$, Tremalli $E$, Biglioli $P$. Lack of association between serum immunoreactivity and Chlamydia pneumoniae detection in the human aortic wall. Circulation. 2002;106:2647-8.

22. Meijer A, van Der Vliet JA, Raholl PJ, Gielis-Proper SK, de Vries A, Ossewaarde JM Chlamydia pneumonlae in abdominal aortic aneurysms: abundance of membrane components in the absence of heat shock protein 60 and DNA. Arterioscler Thromb Vasc Biol 1999;19:2680-6.

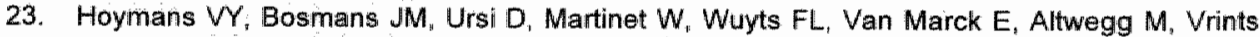
CJ. leven MM. Immunohistochemical staining assays for detection of Chlamydia pneumoniae in atherosclerotic arteries indicate cross-raactions with nonchilamydial plaque constituents. $J$ Clin Microbial. 2004:42:3219-24.

24. Boman J. Hammerschlag MR. Chlamydia pneumoniae and Atherosclerosis: Critical Asisessment of Dlagnostic Methods and Relevance to Treatment Studies. Clin Microbiol Rev. $2002 ; 15: 1-20$.

25. Apfalter $P$, Blasi F, Boman J, Gaydos CA, Kundi $M$. Maass M. Makristathis $A_{\text {. }}$ Meijer $A_{n}$ Nadrchall R, Persson K, Rotter ML, Tong CY, Stanek G, Hirschl AM. Multicenter Comparison Trial of DNA Extraction Methods and PCR Assays for Detection of Chlamydia pneumoniae in Endarterectomy Specimens. I Clin Microbiol. 2001:39:519-24.

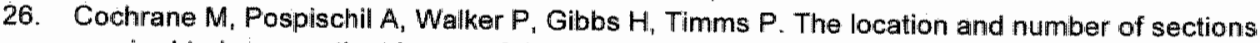
required to increase the chance of detecting chlamydia pneumoniae in atherosclerotic carotid arteries. In: Schachter J, Chrstiansen G, Clarke I, Hammersclag M, Kaltenboeck B, Kuo CC, Rank R, Ridgway G, Saikku P, Stamm WE, Stephens RS, Summersgill JT, Timms P, P.B. W, eds. Chlamwolial Infections. Proceedings of the toth international symposium on human chlamydial infections. San Francisco: International Chlamydia Symposium; 2002:301-4.

27. Mulhilestein JB, Anderson JL, Hammond EH, Zhao L, Tirehan S, Schwobe EP, Carlquist JF. Infection with Chlamydia pneumoniae accelerates the development of atherosclerosis and treatment with azithromycin prevents it in a rabbit model. Circulation. 1998;97:633-6.

28. Ezzahiri R, Nelissen-Vrancken HJ, Kurvers HA. Stassen FR, Vliegen I, Grauls GE, van Pul $M M$, Kitslaar $P J$, Bruggeman $C A$. Chllamydophila pneumoniae (Chlamydia pneumoniae) accelerates the formation of complex atheroscilerotic lesions in Apo E3-Leiden mice. Cardiovasc Res. 2002;56:269-76.

29. Quinn TC, Gaydas CA. In vitro infection and pathogenesis of Chlamydia pneumoniae in endovascular cells. Am Heart J. 1999;138:5507-11.

30. Summersgill JT, Malestina RE, Miller RD, Ramirez JA. Interactions of Chlamydia pneumoniae with human endothelial cells. J'Infect Dis. 2000;181 Suppl 3:S479-82.

31. Molestina RE, Miller RD, Ramirez JA, Summersgill JT. Infection of human endothelial cells with Chlamydia pneumoniae stimulates transendothelial migration of neutrophils and
monocytes. Infect /mmum. 1999:67:1323-30.

32. Maass $M$, Krause $E$, Engel $P M$, Kruger $S$. Endovascular presence of Chlamydia pneumoniae in patients with hemodynamically effective carotid artery stenosis. Angiology. 1997:48:699.
706 . 


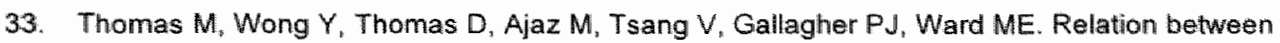
direct detection of Chlamydia pneumoniae DNA in human coronary arteries at postmortem examination and histological severity (Stary grading) of associated atherosclerotic plaque. Circulation. 1999;99:2733-6.

34. Vainas $T$, Kurvers $H A$, Mess $W H$, de Graaf $R$, Ezzahiri $R$, Tordoir $J H$, Schurink GW, Bruggeman CA, Kitslaar PJ. Chlamydia pneumoniae serology is associated with thrombosisrelated but not with plaque-related microembolization during carotid endarterectomy. Stroke. 2002;33:1249-54.

35. Tutuncu NB, Guvener $\mathbb{N}_{\text {。 }}$ Tutuncu $T$, Yilmaz $M$, Guvener $M$, Boke $E$, Pasaoglu I, Erbas $T$. Chlamydia pneumonia seropositivity correlates with serum fibrinogen and lipoprotein a levels: any role in atherosclerosis? Endocr $J .2001 ; 48: 269-74$.

36. Torgano $G$, Cosentini $R$, Mandelli $C$, Perondi $R$, Blasi $F$, Bertinieri $G$, Tien TV, Ceriani $G$, Tarsia $P$. Arosio C, Ranzi ML. Treatment of Helicobacter pylori and Chlamydia pneumoniae infections decreases fibrinogen plasma level in patients with ischemic heart disease. Circulation. 1999;99:1555-9.

37. Netea MG Kullberg BJ, Galama JM, Stalenhoef AF, Dinarello CA, Van der Meer JW. NonLPS components of Chlamydia pneumoniae stimulate cytokine production through Toll-like receptor 2-dependent pathways. Eur J Imanumol. 2002;32:1188-95

38. Kalayoglu MV, Byrne Gl. Induction of macrophage foam cell formation by Chlamydia pneumoniae. J Infect Dis. 1998;177:725-9.

39. Laurila $A$, Bloigu $A_{n}$ Nayha $S$, Hassi J, Leinonen $M$, Saikku $P$. Chronic Chlarnydia pneumoniae infection is associated with a serum lipid profile known to be a risk factor for atherosclerosis. Anteriascler Thromb Vasc Biol. 1997;17;2910-3.

40. Mayr $M$, Metzler B, Kiechl $S$, Willeit J. Schett $G, X u Q$, Wick $G$. Endothelial cytotoxicity mediated by serum antibodies to heat shock proteins of Escherichia coll and Chlamydia pneumoniae: immune reactions to heat shock proteins as a possible link between infection and atherasclerosis. Circulation. 1999;99:1560-6. 
106 


\section{Chapter 6}

Chlamydia pneumoniae serology is associated with thrombosis-related but not with plaquerelated microembolization during carotid endarterectomy

Vainas T, Kurvers HA, Mess $W$, de Graaf R, Ezzahiri R, Tordoir JH, Schurink GW, Bruggeman CA, Kitslaar $P J$

Stroke 2002,33:1249-54 


\subsection{Abstract}

\section{Background}

Chlamydia pneumoniae has repeatedly been associated with atherosclerotic disease. Our study was designed to clarify whether this association is based on Chlamydia pneumoniaeinduced transformation of a stable into an unstable atherosclerotic plaque or on stimulation of hypercoagulability leading to increased thrombotic arterial occlusions by Chyamydia pneumoniae infection. Transcranial Doppler ultrasonographic monitoring of the middle cerebral artery during carotid endarterectomy offers the opportunity to study, before removal of the plaque, atherathrombotic emboli dislodging from an unstable carotid plaque ( $p$ laque-related emboli) and ernboli related to (excessive) thrombus formation at the endarterectomy site after removal of the plaque and restoration of flow (thrombosis-related emboli).

\section{Methods}

Chlamydia pneumoniae lgA- $(\geq 1 / 16)$ and $\operatorname{lgG}(1 \geq 1 / 64)$ seropositivity was assessed in 53 patients with symptomatic carotid artery disease undergoing carotid endarterectomy. The removed carotid plaque s were studied histologically to assess plaque instability.

\section{Results}

Plaque- and thrombosis-related emboli were registered in 43 patients with an adequate transtemporal window. IgA seropositivity $(58 \%)$ was associated significantly with thrombosisrelated embolization $(P=0.030)$, but not with plaque-related embolization or with histological plaque instability.

\section{Conclusion}

Chlamydia pneumoniae serology is associated with micro-embolization after endarterectomy and restoration of flow. Since these micro-emboli represent platelet aggregations and are related to cerebrovascular complications, our data suggest that Chlamydia pneumoniae infection contributes to cerebrovascular events in patients with caratid artery disease through stimulation of thrombosis. 


\subsection{Introduction}

An increasing body of evidence suggests that infections play a role in the initiation and progression of atherosclerotic disease. ${ }^{1}$ Particularly, chronic infections with the gram-negative, intracellular bacterium Chlamydia pneumoniae have been linked to the development of vascular disease. ${ }^{2}$ Chlamydia pneumoniae seropositivity has been associated with acute and chronic coronary artery disease, ${ }^{3-6}$ early and advanced asymptomatic carotid lesions, ${ }^{3-5}$ and stroke. ${ }^{7-9}$ In addition, it has been shown that Chlamydia pneumoniae can infect all cellular components of the vascular wall ${ }^{10}$ inducing proatherogenic changes such as foam cell formation, ${ }^{11}$ endothelial expression of adhesion molecules and chemokines, ${ }^{12}$ stimulation of transendothelial leucocyte migration, ${ }^{13}$ smooth muscle cell proliferation, ${ }^{14}$ endothelial production of tissue factor (TF) ${ }^{15}$ and plasminogen activator inhibitor 1 (PAl-1), ${ }^{16}$ and macrophage production of matrix metalloproteinase 9 (MMP-9). ${ }^{17}$ These observations suggest that Chlamydia pneumoniae infections could contribute to the development of atherosclerosis, leading to atherosclerotic plaque growth and increased arterial stenosis, and that Chramydia pneumoniae infection may also play a role in the formation of an unstable atherosclerotic plaque, leading to acute cardiovascular and/or cerebrovascular events. ${ }^{18}$ Plaque rupture and thrombosis are the main mechanisms of acute arterial occlusion leading to an atherosclerotic event such as myocardial infarction or stroke. ${ }^{19}$ Although Chlamydia pneumoniae infection could theoretically contribute to both processes, it is unclear whether the earlier reported association between Chlamydia pneumoniae serology and acute cardiovascular and cerebrovascular events is based on stimulation of plaque- and/or thrombosis related mechanisms by Chlamydia pneumoniae infection.

Cerebrovascular events related to carotid artery disease are caused in the majority of cases by atherothrombotic emboli dislodging from the carotid plaque. ${ }^{20}$ Fibrous cap rupture and luminal thrombosis are the histological manifestations of carotid plaque instability ${ }^{21}$ and are the main source of cerebral micro-embolic signals (MES), detected by transcranial Doppler ultrasonographic (TCD) monitoring of the ipsilateral middle cerebral artery, in patients with high-grade carotid artery stenosis. ${ }^{22}$ MES not only correlate well with histological determinants of plaque instability but are also associated with clinical manifestations of plaque instability such as strokes and transient ischemic attacks (TIAs). ${ }^{23-25}$ Thrombus formation at the endarterectomy and clamping sites after carotid endarterectomy $(C E A)^{26}$ resulting in either thrombotic occlusion of the carotid artery or downstream embolization of intracranial arteries is the main cause of postoperative stroke and TIA. ${ }^{27}$ Hence, MES occurring during the dissection phase of CEA are associated with carotid plaque instability, whereas MES observed after endarterectomy and 
restoration of flow, as well as in the early postoperative period, are related to excessive platelet aggregation and thrombus formation at the endarterectomy and clamping sites. ${ }^{26}$ TCD monitoring during CEA therefore offers the unique opportunity to study, in wivo plaque instability and thrombosis separately by distinguishing between plaque-related MES (during dissection, pMES) and thrombosis-related MES (after endarterectomy and restoration of flow, tMES). In order to investigate the relation between Chlamydia pneumoniae infection and atherothrombotic disease, we studied the association between Chlamydia pneumoniae serology and carotid plaque histology as well as perioperative micro-embolization in patients undergoing CEA for symptomatic carotid artery disease, with special attention to both pMES and tMES.

\subsection{Materials and methods}

Sixty patients with symptomatic carotid artery disease screened consecutively at the surgical outpatient department of the Maastricht University Hospital who had been found eligible for carotid endarterectomy were asked to participate in this study. Patients who failed to provide informed consent $(n=4)$ or underwent a combined carotid endarterectomy and coronary revascularization procedure $(n=3)$ were excluded. Amaurosis fugax was the presenting symptom of 15 patients; 24 had TIAs, 11 had suffered a stroke, and 3 patients presented with general cerebral hypoperfusion without focal neurological symptoms. All patients had a sigmificant $(>70 \%)$, symptomatic, carotid artery stenosis. ${ }^{28}$ Patient characteristics are given in Table 6.1. The study was approved by the Medical Ethical Committee of Maastricht University Hospital.

Table 6.1. Patient characteristics.

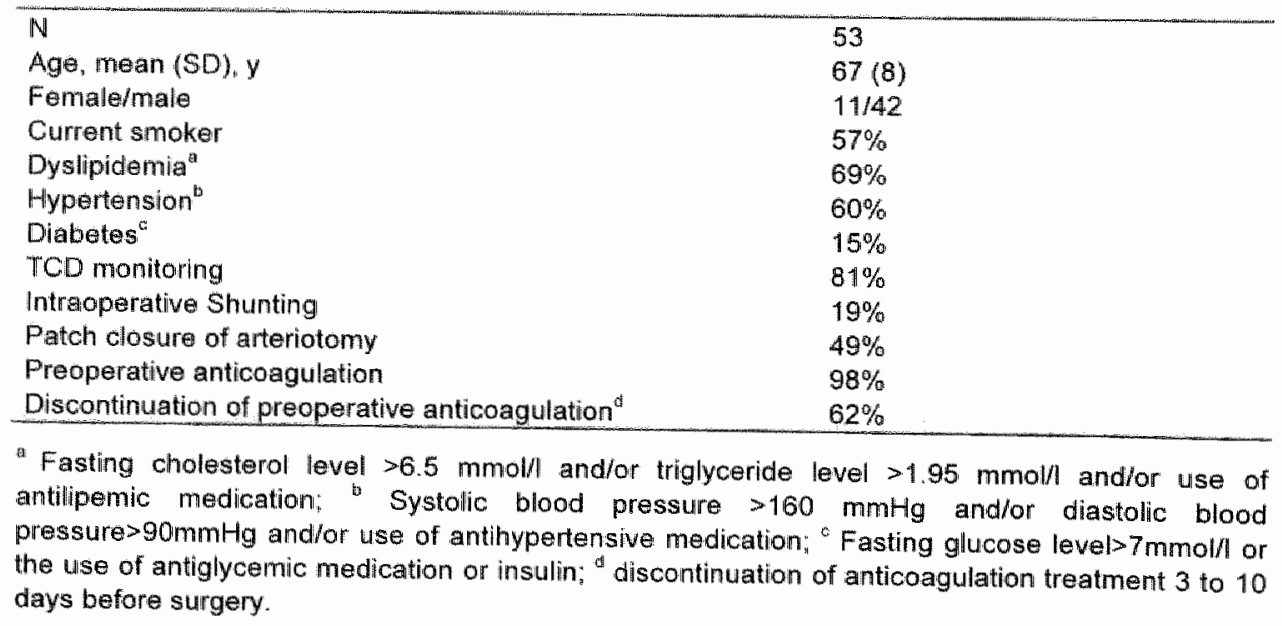




\subsubsection{Carotid endarterectomy (CEA)}

CEA was performed with the patient under normocarbic, normotensive general anesthesia using systemic heparinization ( $1 \mathrm{mg}$ heparine/kg body weight). All but one patients had been on pre-operative anticoagulation therapy; 49 were on acetylsalicylic acid and 3 on coumarin-derivatives. Thirty-three patients stopped the anticoagulation 3-10 days prior to surgery. The endarterectomy was performed through a longitudinal arteriotomy. During the entire procedure, TCD monitoring of blood flow velocity and of MES in the ispilateral middle cerebral artery was performed, if an adequate transtemporal window was present $(n=43)$. A Javid shunt was used selectively in case of imminent hypoperfusion $(n=10)$ as suggested by $>70 \%$ decrease of middie cerebral artery blood flow velocity. ${ }^{29}$ After completion of the endarterectomy, the arteriotomy was closed with a primary suture $(n=27)$ or a patch $(n=26 ; 24$ venous, 1 dacron, 1 PTFE patch) at the discretion of the surgeon. The carotid atheroma harvested during operation was immediately processed for microscopic evaluation. During dissection, $10 \mathrm{cc}$ venous blood was obtained for serological studies.

\subsubsection{MES-detection during CEA}

During CEA, TCD monitoring of the ipsilateral middle cerebrall artery was performed through the transtemporal approach with a 2-MHz probe fixed with a metal frame (Multidop $\times 4$, DWL, Sipplingen, Germany). A satisfactory transtemporal window was present in 43 of the 53 patients. The Doppler signal was recorded on a 2-channel DAT recorder for additional offline analysis. No automatic MES detection system was used. The gain was set to the lowest possible value and the sweep time as fast as possible. The burst length equaled approximately $7.5 \mathrm{~mm}$. MES were evaluated online during the surgical procedure by a technician and additionally offline by an experienced listener (W.H.M.). The criteria for MES used were (1) the typical sound and (2) the appearance as a short-lasting intensity increase in the fast Fourier transform in agreement with the report of a consensus committee. ${ }^{30}$ pMES were counted during dissection and tMES were registered after removal of the plaque and restoration of the flow ( $>5 \mathrm{~min}$ after clamp release). Patients with $\geq 2$ pMES/hour were regarded $\mathrm{pMES}+{ }_{,}{ }^{23}$ and patients with $\geq 6$ tMES/hour were considered tMES+. ${ }^{31}$

\subsubsection{Carotid Plaque Histology}

CEA specimens harvested during operation were divided into multiple macroscopic parts. A macroscopic sketch of the plaque was drawn with attention to the orientation of the different parts. The odd parts were snap 
frozen in liquid nitrogen and stored at $-80^{\circ} \mathrm{C}$ for future analysis. The even parts were formalin fixed and paraffin embedded. A representative $5 \mu \mathrm{m}$ section of each paraffin embedded piece of the carotid atheroma was stained with hematoxyllin and eosin for characterization of plaque (in)stability. Histological plaque instability, defined as the presence of an organized luminal thrombus and/or a ruptured fibrotic cap, ${ }^{21}$ was assessed by two independent investigators ( $T, V$, and R.E.) blinded for the infectious status of the patients. In case of disagreement between the two independent assessments, the plaque was re-evaluated by the two investigators to reach a consensus.

\subsubsection{Chlamydia pneumoniae serology}

Venous blood drawn during operation was immediately centrifuged for $10 \mathrm{~min}$ at $1200 \mathrm{rpm}$ and $44^{\circ} \mathrm{C}$. Serum was stored at $-20^{\circ} \mathrm{C}$ until determination of Chlamydia pneumoniae serology. $\lg A$ and $\lg G$ antibodies were determined by means of a commercially available ELISA (Labsystems, Finland). Titres were calculated form the optical density readings according to the manufacturer's instructions. Chlamydia pneumoniae IgA- and IgG-seropositivity was defined at an $\lg A$-titre $\geq 1 / 16$ and $\lg G$-titre $\geq 1 / 64$, respectively.

\section{3 .5 Statistical analysis}

We used SPSS 10.0 for Windows for statistical analysis. The Fisher's exact test was used for comparison of prevalence of risk factors and patient characteristics between seropositive and seronegative patients, for comparison of tMES/pMES with plaque instability, and for analysis of the association between pMES, tMES or plaque instability and Chlamydia pneumoniae serology. To identify possible confounders, the independent effect of sex, age, smoking, hypertension, dislipidemia, diabetes and discontinuation of preoperative anticoagulation on TMES/pMES was evaluated in simple logistic regression analyses. Parameters that were associated significantly with tMES/pMES in these analyses were entered as potential confounders in a multivariate logistic regression model to study the association between tMES/pMES and Chlamydia pneumaniae-serology. A 2-sided probability value of $<0.05$ was regarded as statistically significant.

\subsection{Results}

Fifty-three patients with symptomatic carotid artery stenosis were included in this study. The duration of operation averaged 110 minutes (range, 73 to 189 minutes). The average clamping and/or shunting time was 35 minutes (range, 20 to 60 minutes). MES were detected during dissection and after endarterectomy and restoration of flow: with the omission of those in the first 5 
minutes after cross-clamp release to avoid false positive registration of gaseous MES. The mean pMES detection time was 64 minutes (range, 45 to 96 minutes), and the mean tMES detection time was 23 minutes (range, 15 to 42 minutes).

One patient developed neurological symptoms the day after operation, which on re-exploration of the carotid artery could be attributed to a fresh thrombus at the site of the primary arterial suture. The thrombus was removed, and the arteriotomy was closed with a venous patch. After that the patient made an uneventful recovery and did not suffer any permanent disabilities. Three more patients developed signs of peripheral facial nerve lesion and recovered fully within a month after hospital discharge.

\subsubsection{Carotid plaque histology}

Carotid atheroma was available for histological analysis in all patients. Signs of plaque instability, i.e., an organized luminal thrombus and/or ruptured fibrotic cap, were seen in 23 patients (43\%). The remaining patients had advanced but stable atherosclerotic lesions, consisting of a thick fibrous cap overlying a lipid/necrotic core with occasional intraplaque hemorrhage.

\subsubsection{Micro-embolization during carotid endarterectomy}

A transtemporal window was present in 43 patients $(81 \%)$. Patients with no cranial window were older than patients with a suitable window (mean age 73 versus 65 years, $P=0.003$ ) which might reflect age-related temporal bone ossification. However, prevalence of cardiovascular risk factors, preoperative diagnosis, operative techniques, plaque histology and Chlamydia pneumoniae serology were comparable in both groups.

Twelve patients had $\geq 2$ pMES per hour and were classified as pMESt. In these patients, the pMES rate varied from 2.5 to 30.8 pMES per hour. The accurrence of pMES correlated strongly with histological plaque instability (Table 6.2).

In 17 patients tMES were observed. Eleven patients had a tMES rate $\geq 6$ IMES per hour and were designated tMES+. Thrombosis-related embolization was not related to plaque histology (Table 6.2). 
Table 6.2 Association between plMES or thES and plaque histology.

\begin{tabular}{lcccc}
\hline & $\begin{array}{c}\text { Unistable plaque, } \\
\text { N }(\%)\end{array}$ & $\begin{array}{c}\text { Stable plaque, } \\
N(\%)\end{array}$ & $\begin{array}{c}\text { total } \\
\mathbb{N}\end{array}$ & $P^{2}$ \\
\hline pMES + & $11(55)$ & $1(5)$ & 12 & \\
pMES & $9(45)$ & $22(95)$ & 31 & 0.003 \\
Total pMES & $20(100)$ & $23(100)$ & 43 & \\
TMES + & $6(30)$ & $5(22)$ & 11 & \\
tMES - & $14(70)$ & $18(78)$ & 32 & 0.728 \\
Total tMES & $20(100)$ & $23(100)$ & 43 & \\
\hline
\end{tabular}

pMES+ indicates $\geq 2$ pMES per our; pMES - $<2$ pMES per hour; tMES *, $\geq 6$ tMES per hour; tMES$\leftarrow 6$ tMES per hour. ${ }^{\text {ai }}$ statistical analysis by Fisher's exact-test, significance at $P<0.05$.

\subsubsection{Chlamydia pneumoniae serology}

Elevated levels of Chlamydia pneumoniae antibody titers were a common finding in our patients. Fifty-eight percent were Chlamydia pneumoniae IgAseropositive ( $\lg A \geq 1 / 16$ ), and $60 \%$ were Chlamydia pneumoniae IgGseropositive ( $\lg G \geq 1 / 64)$. The distribution of cardiovascular risk factors and the use of an intraluminal shunt or a patch for arteriotomy closure were comparable in seropositive and seronegative patients (Table 6.3).

Table 6.3 Distribution of cardiovascular risk factors and operative techniques among Chlamydia pneumoniae seropositive and seronegative patients.

\begin{tabular}{lcccccc}
\hline & $\operatorname{lgG}+$ & $\mathrm{lgG}-$ & $P^{\text {a }}$ & $\operatorname{lgA}+$ & $\operatorname{lgA}-$ & $P^{\text {a }}$ \\
\hline $\mathrm{N}$ & 32 & 21 & $\mathrm{~ns}$ & 30 & 23 & $\mathrm{~ns}$ \\
Agle (years) & 68 & 65 & $\mathrm{~ns}$ & 67 & 66 & $\mathrm{~ns}$ \\
female/male & $5 / 27$ & $6 / 15$ & $\mathrm{~ns}$ & $5 / 25$ & $6 / 17$ & $\mathrm{~ns}$ \\
Current smoker & $56 \%$ & $57 \%$ & $\mathrm{~ns}$ & $60 \%$ & $52 \%$ & $\mathrm{~ns}$ \\
Dyslipidemia & $63 \%$ & $76 \%$ & $\mathrm{~ns}$ & $64 \%$ & $74 \%$ & $\mathrm{~ns}$ \\
Hypertension & $63 \%$ & $76 \%$ & $\mathrm{~ns}$ & $63 \%$ & $57 \%$ & $\mathrm{~ns}$ \\
Diabetes & $13 \%$ & $19 \%$ & $\mathrm{~ns}$ & $10 \%$ & $22 \%$ & $\mathrm{~ns}$ \\
Perioperative shunting & $22 \%$ & $14 \%$ & $\mathrm{~ns}$ & $27 \%$ & $9 \%$ & $\mathrm{~ns}$ \\
Patch closure & $50 \%$ & $48 \%$ & $\mathrm{~ns}$ & $50 \%$ & $48 \%$ & $\mathrm{~ns}$ \\
Discontinuation of preoperative & $56 \%$ & $67 \%$ & $\mathrm{~ns}$ & $55 \%$ & $70 \%$ & $\mathrm{~ns}$ \\
anticoagulation & & & & & &
\end{tabular}

$\lg \mathrm{G}+$ indicates $\lg \mathrm{G}$ seropositivity $(\geq 1 / 64) ; \operatorname{lgG}-, \lg \mathrm{G}$ seronegativity $(<1 / 64) ; \lg A+, \lg \mathrm{A}$ seropositivity ( $21 / 16$ ); and $\operatorname{lgA}-, \lg A$ seronegativity $(<1 / 16)$. " statistical analysis by Fisher's exact test; statisticall significance at P<0.05: ns, not significant.

\subsubsection{Influence of Chlamydia pneumoniaeinfection on carotid artery disease}

Table 6.4 shows the association between Chlamydia pneumoniae serology and histological plaque instability, plaque-related embolization and thrombosis- 
related embolization. Chlamydia pneumoniae seropositivity was not related to histological plaque instability or plaque-related emboli. However, $\lg A$ seropositivity was associated with thrombosis-related emboli $(P=0.014)$ and IgG seropositivity showed a trend towards association with IMES $(P=0.077)$. After correction for confounding covariables, only lgA seropositivity was still significantly associated with tMES $(P=0.030)$. Of the potential confounders sex, age, smoking, dyslipidemia, hypertension, diabetes, and discontinuation of preoperative anticoagulation only the latter was univariantly associated with tMES $(P=0.030)$ and tended toward association with pMES $(P=0.075)$; it was therefore the only confounding variable introduced in the multivariate regression analysis.

Table 6.4 Relation between Chlamydia pneumoniae serology (IgA and ligG seropositivity) and histological plaque instability, pMES or tMES

\begin{tabular}{|c|c|c|c|c|c|c|}
\hline \multirow[b]{2}{*}{ Dependent variable } & \multicolumn{3}{|c|}{$\lg A+$} & \multicolumn{3}{|c|}{$\lg \mathrm{G}+$} \\
\hline & OR: & $95 \%-\mathrm{Cl}$ & $P$ & OR & $95 \% \circ \mathrm{CH}$ & $P$ \\
\hline \multirow[t]{2}{*}{ Pliaque instability } & 1.0 & $0.3-3.0$ & 0.994 & 0.8 & $0.2-2.8$ & 0.616 \\
\hline & $1.0^{\mathrm{B}}$ & $0.3-3.2^{\mathrm{a}}$ & $0.932^{\mathrm{a}}$ & $0.8^{a}$ & $0.3-2.4^{a}$ & $0.679^{\mathrm{a}}$ \\
\hline \multirow[t]{2}{*}{ PMES+ } & 1.6 & $0.4-6.6$ & 0.483 & 1.9 & $0.5-7.5$ & 0.376 \\
\hline & $1.8^{\mathrm{a}}$ & $0.4-8.6^{a}$ & $0.474^{a}$ & $1.9^{a}$ & $0.4-9.4^{a}$ & $0.408^{\mathrm{a}}$ \\
\hline \multirow[t]{2}{*}{ tMES* } & 11.3 & $1.3-99.1$ & 0.014 & 5.1 & $0.95-27.4$ & 0.058 \\
\hline & $12.1^{\mathrm{a}}$ & $1.3-114.2^{\mathrm{a}}$ & $0.030^{\mathrm{a}}$ & $4.8^{8}$ & $0.84-27.4^{4}$ & $0.078^{8}$ \\
\hline
\end{tabular}

OR indicates odds ratio. Plaque instability includes fibrous cap rupture and/or organized luminal thriombosis. Other definitions are as in Tables 6.2 and 6.3. Statistical analysis by Fisher's exact test and multivariate logistic regression analysis including 'discontinuation of premoperative anticoagulation' in the analysis; statistical significance at $P<0.05$. "Mullitwariate logistic regression analysis

\subsection{Discussion}

Atherosclerosis is a chronic inflammatory disease. ${ }^{32}$ Chronic infections, especially Chlamydia pneumoniae infections, may play an important role in the initiation and progression of this inflammatory process. ${ }^{2}$ Chlamydia pneumoniae can induce proatherogenic changes in endothelial cells, ${ }^{12,13,15}$ macrophages ${ }^{11,17}$ and smooth muscle cells; ${ }^{14,16.33}$ Chlamydia pneumoniae seropositivity has been associated with acute ${ }^{7-9,34-36}$ and chronic ${ }^{34,37}$ clinical atherosclerotic manifestations; and Chlamydia pneumoniae has been detected more frequently in atherosclerotic tissue compared with normal arteries. ${ }^{2}$ However "the vascular presence of Chlamydia pneumoniae has not been associated with coronary plaque morphology ${ }^{38}$ or plaque-related cerebral microembolization. ${ }^{39}$ Since the development of acute cardiovascular complications is associated with plaque instability and/or thrombotic occlusions of blood vessels, we wanted to study the association between Chlamydia oneumoniae serology, plaque instability, and hypercoagulability. In the present 
study Chlamydia pneumoniae serology was not associated with plaque instability but showed a strong relation with thrombosis-related microembolization during CEA, an in vivo marker of hypercoagulability.

Application of TCD monitoring of the ispilateral middle cerebral artery during CEA offers the possibility to study the wo basic mechanisms that contribute to cardio- and cerebrovascular events separately, ile. plaque destabilization and (excessive) thrombosis. MES during the dissection phase of CEA have been associated with histological determinants of plaque instability (i.e., plaque rupture and/or luminal thrombosis). ${ }^{22}$ A pMES rate $\geq 2$ pMES per hour has been associated with increased risk of developing cerebral ischemia. ${ }^{23}$ Therefore, the occurrence of MES during dissection is an in vivo marker of plaque instability, and patients with $\geq 2$ pMES per hour were defined as pMES + . After endarterectomy and restoration fflow , in the absence of an unstable plaque, MES represent thrombocyte aggregations formed at the highly thrombogenic endarterectomy and clamping sites. In a series of 276 CEAs, the median embolic rate postoperatively was 1.33 MES per hour (interquartile range $0-5.67$ MES/hour). "A high embolic rate after CEA (in the upper quartile of MES-rate, i.e., $\geq 6$ tMES per hour) probably identifies patients with excessive thrombus formation or inadequate thrombolysis. Therefore, for the purposes of this study, a MES rate $\geq 6$ tMES per hour was regarded as an in vivo marker of hypercoagulability, and patients with $\geq 6$ tMES per hour were designated tMES+. In agreement with previous reports, pMES were associated with histological plaque instability in this study. ${ }^{22}$ However tMES were not related to histology.

The average embolic count was related to operation time in our patients. Interestingly, only plaque related MES correlated with this variable. Operation time was a strong predictor of embolic count during dissection $(P=0.002)$ but not of embolic count after endarterectomy and restoration of flow $(P=0.873)$. To avoid the confounding effect of operation time on the association between Chlamydia pneumoniae serology and micrombolization, the embolic rate (micro-mboli per hour) was used to define patients with clinically relevant plaque-related ( $\geq 2$ pMES per hour) or thrombosis-related ( $\geq 6$ tMES per hour) embolization.

Chlamydia pneumoniae serology has been associated with cerebrovascullar events, ${ }^{6-9}$ carotid intima-media thickness, 3,40 and sonographically detected carotid plaques. ${ }^{3.41}$ Nevertheless, a number of studies have failed to show an association between Chlamydia pneumoniae serology and ischemic cerebrovascular disease. ${ }^{42,43}$ However, the amount of positive evidence accumulated suggests that this association is material and not coincidental. Negative reports may have been hampered by biased study population and end point selection, limitations of the diagnostic assays used or even the unfortunate coincidence of a Chlamydia pneumoniae epidemic during sample 
acquisition. In a randomly selected urban population, no association existed between Chlamydia pneumoniae serology and carotid intima-media thickness and/or the presence of sonographically detected carotid plaque. ${ }^{42}$ However in patients with hypertension, ${ }^{40}$ coronary and peripheral arterial disease ${ }_{n}{ }^{3}$ cerebrovascullar disease, ${ }^{6}$ and end-stage renal disease, ${ }^{41}$ an association between Chlamydia pneumoniae serology and carotid intima-media thickness or degree of stenosis could be found. In a nested case control study, Glader et al. found no association between baseline Chlamyolia pneumoniae serology and the development of future ischemic cerebral infarction. ${ }^{43}$ The authors suggested that a Chlamydia pneumoniae epidemic at the time of patient inclusion and blood sampling might have masked a possible association between Chlamydia pneumoniae serology and cerebrovascular disease, a problem that could have been bypassed if antibody titres would have been detected in paired serum samples.

Despite numerous reports on the association between Chlamydia pneumoniae serology and cardiovascular disease, no consensus has been reached regarding the serological criteria for chronic or persistent Chlamydia pneumoniae infection. Various cut-off points for $\operatorname{lgA}$ and IgG titres or even IgA and IgG titre combinations have been used. ${ }^{44}$ The heterogeneity of serological assays and of serological criteria for persistent or chronic Chlamydia pneumoniae infections might also have contributed to conflicting results of some seroepidemiological studies. The microimmunofluorescence test is regarded as the reference method for Chlamydia pneumoniae serology. However, Gnarpe et al. found a good correlation between enzyme immunoassay and microimmunofluorescence test in patients with hypertension or ischemic heart disease who had a low background of C.trachomatis antibodies. ${ }^{45}$ The sensitivity, specificity, and positive and negative predictive value was $91,80,96$ and 63 for $\operatorname{lgG}$ and $85,88,92$ and 79 for $\lg A$, respectively, with the microimmunofluorescence test regarded as gold standard. Likewise, in our laboratory, the sensitivity, specificity, and positive and negative predictive values of the enzymeimmunoassay compared with the microimmunofluorescence test were 95, 89, 98 and 77 for $\lg A$ and $95,73,96$ and 75 , respectively, for $\lg G$ in a series of 239 samples from patients with peripheral arterial disease $(n=150)$ and healthy controls $(n=89)$. The intertest agreement between the enzymeimmunoassay and the microimmunofluorescence test was very good for $\lg A(k=0.679)$ and for $\lg G(k=0.681)(T$. Vainas, et al., unpublished data, 2001). Considering the adequate performance and the practical advantages of the enzyme-immunoassay compared with the microimmunofluorescence test (high throughput, objective endpoint, costefficiency), we had chosen the first method to determine Chlamydia pneumoniae serology in this study. IgA titres $\geq 1 / 16$ and $\lg G$ titres $\geq 1 / 64$ were considered positive in view of the results of previous studies showing an 
association between Chlamydia pneumoniae infection and carotid artery disease. ${ }^{5.6}$ According to these cut-off levels, IgA seropositivity was associated with a high thrombosis-related embolic rate but not with plaque instability. Since IgA titres decline and disappear after 3-12 months of infection whereas IgG antibodies may persist for some years, it is believed that persistence of the short-lived IgA may be a better marker of chronic infection than $\mathrm{IgG}{ }^{46}$ Hence, chronic Chlamydia pneumoniae infection is associated with an in vivo marker of hypercoagullability in patients undergoing CEA for symptomatic carotid artery disease.

In this study Chlamydia pneumoniae serology was not related to plaque instability but correlated with tMES. This suggests that the reported association between Chlamydia pneumoniae infection and cardiovascular disease might be mediated through stimulation of thrombosis-related events rather than plaquerelated phenomena by Chlamydia pneumoniae infection. Interestingly, immunohistochemical detection of Chlamydia pneumoniae in carotid atheroma of 76 patients has strongly been associated with thrombosis but not with plaque ulceration, suggesting that Chlamydia pneumoniae infection was independently associated with a greater risk of thrombosis on the plaques but not with plaque ulceration. ${ }^{47}$ The separate analysis of pMES and tMES in our study showed that Chlamydia pneumoniae seropositivity indeed is associated with tMES rather than pMES, favoring a prothrombotic and/or antithrombolytic effect of Chlamydia pneumoniae infection in carotid artery disease. Previous studies have shown that Chlamydia pneumoniae infection of endothelial cells stimulates the nuclear factor-kB signal transduction pathway, inducing a 4-fold increase of tissue factor ${ }^{15}$ and stimulating the expression of plasminogen activator inhibitor $1,{ }^{16}$ resulting in increased local thrombogenicity. Moreover, plasma fibrinogen levels are elevated in patients with chronic Chlamydia pneumoniae infections ${ }^{48}$ and decrease on antimicrobial treatment. ${ }^{49}$ These observations offer a novel perspective on the association between Chlamydia pneumoniae infection and cardiovascular events and warrant further investigation of the prothrombotic and antithrombolytic effects of Chlamydia pneumoniae infection in atherothrombotic arterial disease. ${ }^{50}$ 


\subsection{References}

1. de Boer OJ, van der Wal $\mathrm{AC}$, Becker $\mathrm{AE}$. Atherosclerosis, inflammation, and infection. $y$ Pathol. 2000; 190:237-43.

2. Grayston JT. Does Chlamydia pneumoniae cause atherosclerosis? Arch Surg. 1999; 134: $930-4$.

3. Espinola-Klein $C_{i}$ Rupprecht $H J$, Blankenberg $S$, et al. Are morphological or functional changes in the carotid artery wall associated with Chlamydia pnewmoniae. Helicobacter pylori, cytomegalowirus, or herpes simplex virus infection? Stroke 2000; 31:2127-33.

4. Melnick SL, Shahar E, Folsom AR, et al. Past infection by Chlamydia poneumoniae strain TWAR and asymptomatic carotid atherosclerasis. Atherosclerosis Risk in Communities (ARIC) Study Investigators. Am J Med. 1993; 95:499-504.

5. Markus HS, Sitzer $M$, Carrington D, Mendall MA, Steinmetz $H$. Chlamydia pneumoniae infection and early asymptomatic carotid atherosclerosis. Circulation. 1999; 100:832-7.

6. Sander D, Winbeck $K_{\mathrm{s}}$ Klingelhofer J Etgen $T$. Conrad B. Enhanced progression of early caratid atherosclerosis is related to Chlamydia pneumoniae (Taiwan acute respiratory) seropositivity. Circulation. 2001; 103:1390-5.

7. Wimmer ML, Sandmann-Strupp $R$, Saikku P, Haberl RL. Association of chlamydial infection with cerebrovascular disease. Stroke. 1996; 27:2207-10.

8. Cook PJ, Haneybourne D, Lip GY, Beevers DG, Wise R, Davies P. Chlamydia pneumoniae antibody titers are significantly associated with acute stroke and transient cerebral ischemia: the West Birmingham Stroke Project. Stroke. 1998; 29;404-10.

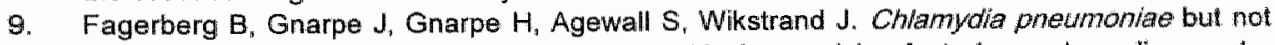
cytomegalovirus antibodies are associated with future risk of stroke and cardiovascular disease: a prospective study in middle-aged to elderly men with treated hypertension. Stroke. 1999; 30:299-305.

10. Godzik KL, O'Brien ER, Wang SK, Kuo CC. In vitro susceptibility of human vascular wall cells to infection with Chlamydia pneumoniae. I Clin Microbiol. 1995; 33:2411-4.

11. Kalayoglu MV, Byrne GI. Induction of macrophage foam cell formation by Chlamydia pneumoniae. $J$ infect Dis. 1998; 177:725-9.

12. Kaukoranta-Tolvanen $S S$, Ronni $T$, Leinonen $M$, Saikku $P$, Laitinen $K$. Expression of adhesion molecules on endothelial cells stimulated by Chamydia pneumoniae. Microb Pathog. 1996; 21:407-11.

13. Molestina RE, Miller RD, Ramirez JA, Summersgill JT. Infection of human endothelial cells with Chlamydia preumoniae stimulates transendothelial migration of neutrophils and monocytes. Infect Immun. 1999; 67:1323-30.

14. Coombes BK, Mahony JB. Chiamydia prewmoniae infection of human endothellial cells induces proliferation of smooth muscle cells via an endothelial cell-derived soluble factor(s). Infect immun. 1999; 67:2909-15.

15. Fryer $\mathrm{RH}$, Schwobe EP, Woods ML, Rodgers GM. Chlamydia species infect human vascular endothelial cells and induce procoagulant activity. J Investig Med. 1997; 45:168-74.

16. Dechend $R_{4}$ Maass $M$, Gieffers $J$, et al. Chlamydia pneumoniae infection of vascular smooth muscle and endothelial cells activates NF.kappaB and induces tissue factor and PAI-1 expression: A potential link to accelerated arteriosclerosis. Circulation. 1999; 100:1369-73.

17. Koll A, Sukhova GK, Lichtman AH, Libby $P$. Chlamydial heat shock protein 60 localizes in human atheroma and regulates macrophage tumor necrosis factor-alpha and matrix metalloproteinase expression. Circulation. 1998; 98:300-7.

18. Becker $A E$, de Boer OJ, van Der Wal $A C$. The role of inflammation and infection in coronary artery disease. Ann Rev Med. 2001; 52:289-97.

19. Gutstein DE, Fuster V. Pathophysiology and clinical significance of atherosclerotic plaque rupture. Cardiovasc Res. 1999; 41:323-33.

20. Foulkes MA, Wolf PA, Price TR, Mohr JP, Hier DB. The Stroke Data Bank: design, methods, and baseline characteristics. Stroke. 1988" 19:547-54. 
21. Lamme GA, Sandercock PA, Dennis MS. Fecently accluded intracranial and extracranial carotid arteries. Relevance of the unstable atherosclerotic plaque. Stroke. 1999; 30:1319-25.

22. Sitzer $M$, Muller $W$, Siebler $M$, et al. Plaque ulceration and lumen thrombus are the main sources of cerebral microemboll in high-grade intemal carotid artery stenosis. Stroke. 1995; 26:1231-3.

23. Siebler $M_{1}$ Nachtmann $A_{1}$ sitzer $M$, al. Cerebral micrcembolism and the risk of ischemia in asymptomatic high-grade internal carotid artery stenosis. Stroke. $1995 ; 26: 2184-6$.

24. Molloy J, Markus HS. Asymptomatic embolization predicts stroke and TIA risk in patients with carotid artery stenosis. Stroke. 1999; 30:1440-3.

25. Tegos TJ, Sabetai MM, Nicolaides AN, et al. Correlates of embollic events detected by means of transcranial Doppler in patients with carotid atheroma. I Vasc Surg. 2001: 33:131-8.

26. Stratton JR, Zlerler RE, Kazmers A. Platelet deposition at carotid endarterectomy sites in humans. Stroke. 1987; 18:722-7.

27. Spencer MP. Transcranial Doppler Monitoring and Causes of Stroke From Carotid Endarterectomy. Stroke: $1997 ; 28.685-91$.

28. Randomised trial of endarterectomy for recently symptomatic carotid stenosis: final results of the MRC European Carotid Surgery Trial (ECST). Lancet. 1998; 351:1379-87.

29. Jansen $C_{8}$ Moll FL, Vermeulen FE, wan Haelst JM, Ackerstaff RG. Continuous transcranial Doppler ultrasonography and electroencephalography during carotid endarterectomy: a multimodal monitoring system to detect intraoperative ischemia. Ann Vasc Surg. 1993:7: 95-101.

30. Basic Identification Criteria of Doppler Microembolic Signals. Stroke. 1995; 26:1123.

31. Hayes $P D$. Allroggen $H$, Steel $S$, al Randomized trial of vein versus Dacron patching during carotid endarterectomy: influence of patch type on postoperative embolization. $J$ Vasc Surg. 2001; 33:994-1000.

32. Ross R. Atheroselerosis--an inflammatory disease. N Engl. $/$ Med. 1999; 340:115-26.

33. Sasu S, Laverda D, Qureshi N, Golembock DT, Beasley D. Chlamydia pneumoniae and chlamydial heat shock protein 60 stimulate proliferation of human vascular smooth muscle cells via toll-like receptor 4 and p44/p42 mitogen-activated protein kinase activation. Circ Res. 2001; 89:244-50.

34. Saikku $P$, Leinonen $M$, Mattila $K$, et al. Serological evidence of an association of a novel Chlamydia, TWAR, with chronic coronary heart disease and acute myocardial infarction. Lancet. 1988; 2:983-6.

35. Aceti $A$, Mazzacurati $G$. Amendolea $M$, et al. Relation of $C$ reactive protein to cardiovascular risk factors. $\mathrm{H}$ pylori and $\mathrm{C}$ pneumoniae infections may account for most acute coronary syndromes. BML. 1996; 313:428-9.

36. Leinonen $M$, Linnanmaki $E$. Mattila $K$, et al. Circulating immune complexes containing chlamydial lipopolysaccharide in acute myocardial infarction. Microb Pathog. 1990; 9:67-73.

37. Linnanmaki $E$, Leinonen $M$. Mattila $K$, Nieminen MS, Vattonen $V$, Saikku $P$. Chlamydia pneunoniaespecific circulating immune complexes in patients with chronic coronary heart disease. Circulation. 1993; $87: 1130-4$.

38. Thomas $M$, Wong $Y$. Thomas $D$, al. Relation between direct detection of Chlamydia pneumoniae DNA in human coronary arteries at postmortem examination and histological severity (Stary grading) of associated atherosclerotic plaque. Circulation. 1999; 99:2733-6.

39. Gibbs RG, Sian M, Mitchell AW, Greenhaigh RM, Davies AH, Carey N. Chlamydia pneumomiae does not influence atherosclerotic plaque behavior in patients with established carotid artery stenosis. Stroke $2000,31: 2930-5$

40. Schmidt $\mathrm{C}$. Hulthe J, Wikstrand $J$, et al. Chlamydia pneumoniae seropositivity is associated with carotid artery intima-media thickness. Stroke $2000 ; 31: 1526-31$.

41. Zoccali $C$, Benedetto $F A$, Mallamaci $F$, et al. Inflammation is associated with carotic atherrosclerosis in dialysis patients. Creed Investigators. Cardiovascular Risk Extended Evaluation in Diallysis Patients. J Hypertens. 2000; 18:1207-13.

42. Coles KA, Plant Ad, Riley TV, Smith DW, McQuillan BM. Thompson PL. Lack of association between seropositivity to Chramydia pneumoniae and carotid athersclerosis. Am I Cardial. $1999 ; 84: 825-8$. 
43. Glader CA, Stegmayr B, Boman J, et al. Chamydia pneumoniae Antibodies and High Lipoprotein(a) Levels Do Not Predict ischemic Cerebral Infarctions : Results From a Nested Case- Control Study in Northern Sweden. Stroke 1999; 30:2013-2018.

44. Siscovick DS, Schwartz SM, Caps M. Wang SP, Grayston JT. Chamydia preumoniae and atherosclerotic risk in populations: the role of seroepidemiology. I Infect Dis. 2000; 181 Suppl 3:S4 17-20.

45. Gnarpe J. Naas J, Lundback A. Comparison of a new commercial ElA kit and the microimmunofluorescence technique for the determination of $\lg G$ and $\lg A$ antibodies to Chlamydia pneumoniae. Apmis. 2000; 108:819-24.

46. Saikku $\mathrm{P}$, Leinonen $\mathrm{M}$, Tenkanen $\mathrm{L}$, et al. Chronic Chlanyrdia pneumoniae infection as a risk factor for coronary heart disease in the Helsinki Heart Study. Ann Intern Med. 1992; 116:2738.

47. Chiu B, Vira E, Tucker W, Fong IW. Chlamydia pneumoniae, cylomegalovirus, and herpes simplex virus in atherosclerosis of the carotid artery. Circutation. 1997: 96:2144-8.

48. Tutuncu NB, Guvener N. Tutuncu $T$, et al. Chlamydia pneumonia seropositivity correlates with serum fibrinogen and lipoprotein a levels: any role in atherosclerosis? Endocr J. 2001; 48:269-74.

49. Torgano $G$, Cosentini $R_{0}$ Mandelli $C_{n}$ et al. Treatment of Helicobacter pylori and Chlamydia pneumoniae infections decreases fibrinogen plasma level in patients with ischemic heart disease. Circulation. 1999; 99:1555-9.

50. Shah PK. Plaque disruption and thrombosis: potential role of inflammation and infection. Cardial Rev. 2000; 8:31-9. 
122 


\section{Section 4}

Genetic determinants of atherosclerosis

\section{susceptibility}


24 


\section{Chapter 7}

Synergistic effect of Toll-Like Receptor 4 and CD14 polymorphisms on the total atherosclerosis burden in patients with peripheral arterial disease

Vainas $T$, Stassen FR, Bruggeman CA, Welten RJ, van den Akker $L H$, Kitslaar PJ, Peña AS, Morré SA 


\subsection{Abstract}

\section{Background}

Genes involved in the regulation of immune responses, such as Toll Like Receptor 4 (TLR4) and CD14, show genetic variations with potential functional implications. Since atherosclerosis is an inflammatory process apparently modulated by chronic infections, we studied the effect of single nucleotide polymorphisms (SNPS) in TIR4 and CD14, on the extent of atherosclerosis in patients with peripheral arterial disease (PAD).

\section{Materials and methods}

Using an in-house developed PCR-based restriction length polymorphism assay, we determined the genotype, allele frequency and carrier trait of the $T L R 4+896, A>G$ and the CD14 $-260 C>T$ SNPs in 607 Dutch Caucasian patients with PAD. The extent of atherosclerosis was determined on the basis of the number of vascular territories involved, i.e. coronary, cerebral, aortic and peripheral.

\section{Results}

$55 \%$ of the patients suffered from PAD only. Approximately $1 / 3^{\text {rd }}$ of the patients had 2 and $11 \%$ had 3 vascular territories affected by atherosclerosis. The $T L R 4+866$ Gallele frequency was $11 \%$ and the CD14-260 T-allele frequency was approximately 74\%. Among PAD patients, $7 L R 4+896$ $G$ allele carrier-ship was univariantly associated with extensive ( $>2$ vascular territories affected) atherosclerotic disease (OR: 2.22, $P=0.020, \chi^{2}$ test), whereas CD14 -260 C>T carriership/ homozygote was not. Trend analysis showed that the $T L R 4+866 \mathrm{G}$-allele frequency increases with the number of vascular territories affected by atherosclerosis ( $P$-trend 0.0074$)$. In a multivariate logistic regression analysis, including cardiovascular risk factors, TLR4-and CD14 SNPs, onlly the interaction variable ' $T L R 4+896$ " $G$ allele carrier-ship-CDT4-260 TT genotype' survived as independent predictor of extensive atherosclerotic disease $(P=0.031, O R=4.2,95 \% \mathrm{Cl}: 1.1-15.4)$.

\section{Conclusion}

The carrier trait "TLRA Gallele \& CDT4 TT-genotype", rather than each SNP individually, is associated with extent of atherosclerotic disease. Considering the importance of immune responses in atherogenesis and the genetic variation of immune regulatory genes, our data provide an explanation for inter-individual differences in susceptibility to atherosclerosis and demonstrate the need to take a wider approach analyzing relevant carrier traits instead of individual polymorphisms in relation to atherosclerosis. 


\subsection{Introduction}

Inflammatory processes have been implicated in the pathogenesis of atherosclerosis. ${ }^{1}$ Responses of the innate immune system to endothelial injury are involved in the initiation of atherosclerosis and inappropriate activation of the innate and acquired immune system play a pivotal role in the propagation of the disease. ${ }^{2}$ Among the triggers of such atherogenic immune responses are endogenous antigens such as oxidized low density lipoprotein (LDL), and exogenous pathogen associated molecular patterns (PAMPs) such as lipopolysaccharide (LPS) and exogenous and endogenous heat shock proteins (HSPs). Indeed, chronic infections, especially Chlamydia pneumoniae infections, have recently been implicated in the pathogenesis of atherosclerosis. ${ }^{3}$

The innate immune system plays a key role in the defence against pathogens and, when gone awry, may contribute to the development of chronic inflammatory conditions. Pattern-recognition receptors (PRRs) such as Toll-like receptors (TLRs) are involved in the elimination of pathogens through recognition of PAMPs, setting off a cascade of pro-inflammatory reactions, which, if not balanced, may exacerbate chronic inflammatory processes. TLR4 is the first TLR described in mammals ${ }^{4}$ and functions not only as a receptor for LPS but for agonists such as human and chlamydial HSPS as well. ${ }^{5}$ LPS binding is complex and requires several accessory molecules, among which, CD14, LPS binding protein (LBP) and MD-2. ${ }^{6}$ Candidate gene approaches investigate genetic variation including the effect of (functional) single nucleotide polymorphisms (SNPs) in genes involved in the immune response on disease susceptibility and/or severity. In polygenic and multifactorial diseases, like atherosclerosis, these approaches might identify risk factors in the context of aetiological and genetic heterogeneity. Potential candidate genes for investigating the susceptibility to and severity of atherosclerosis include PRRs such as TLR4 and CD14. Activation of these receptors results in the activation of nuclear factor-kB (NF-kB) followed by transcription of various proinflammatory cytokine genes like tumour necrosis factor- $\alpha$ (TNF- $\alpha$ ), interleucin (IL) $-1 \alpha$ and IL-1 $\beta$. Thus, genetic variations in PRRs provide a plausible explanation for altered responsiveness of the innate immune system and may be associated with altered susceptibility to infectious and inflammatory processes and severity or outcome of disease. The recently described human TLR4 polymorphism, i.e., a missense SNP substituting an aspartic acid residue with glycin at amino acid 299 (Asp299Gly; nucleotide position $T L R 4+896 \mathrm{~A}>G$ ), has been associated with hyporesponsiveness to LPS and reduced expression of TLR4. ${ }^{7}$ in the general population, this polymorphism has been associated with decreased interleukin-6 (IL-6), fibrinogen, soluble vascular adhesion molecule 1 (VCAM-1), procalcitonin and neopterin plasma levels, and 
seemingly confers protection against the development of carotid and femoral atherosclerosis ${ }^{8.9}$ and acute coronary events. ${ }^{10}$ Among pravastatine users it has significantly been associated with a lower cardiovascular risk." A functional polymorphism in the promotor region of $C D 14$ at position -260 , the $C D 14-260 C>T$ polymorphism, which enhances the transcriptional activity of the CD14 gene, has been associated with increased carotid artery intima media thickness, ${ }^{12}$ an enhanced risk of stroke ${ }^{13}$ and acute myocardial infarction. ${ }^{14.15}$ Nevertheless, several authors demonstrated a lack of association between this polymorphism and coronary artery or cerebrovascular disease. ${ }^{\text {16- }}$ 18

Although candidate gene approaches may identify signal transduction pathways of importance for a specific disease, they usually find only relative small contributions for an individual gene to the overall susceptibility to disease. Therefore, so-called carrier trait analyses are increasingly used. These strategies analyze SNPs in different genes together and investigate if potential synergic effects can be observed. A good example of the effect of such analyses is shown in a recent study by El-Omar and colleagues who evaluated the role of proinflammatory cytokine gene polymorphisms in gastric and esophageal cancers. ${ }^{19}$ They showed that combined carriage of multiple proinflammatory polymorphisms of $\| \mathrm{L}-1 \mathrm{~B}, \mathrm{IL}-1$ receptor antagonist, TNF- $\alpha$, and IL-10 conferred greater risk, with ORs (and 95\% confidence intervals) of 2.8 (1.6-5.1) for one, $5.4(2.7-10.6)$ for 2 , and $27.3(7.4-99.8)$ for 3 or 4 high-risk genotypes.

In the present study we assessed the association between the $\pi L R 4+896 A>G$ and $C D 14(-260) C>T$ polymorphisms individually with extent of atherosclerosis in patients with peripheral arterial disease. Furthermore, using a multivariate logistic regression model we analysed the effect of the combination of both polymorphisms on extent of atherosclerotic disease in these patients.

\subsection{Materials and methods}

\subsubsection{Study population}

Dutch Caucasian patients, all diagnosed with peripheral arterial disease, where recruited at the surgical clinics of an university hospital and two affiliated teaching hospitals. Ankle-brachial pressure index (ABPI) measurement was used to objectify the presence of atherosclerotic disease of lower limb arteries. An $\mathrm{ABP} \mid<0.9$ was regarded pathognomonic. In order to identify additional cardio- and cerebrovascular co-morbidities, medical charts were reviewed and attending physicians were consulted. Also, the presence/absence of AAA was ascertained in all patients by means of duplex ultrasound and/or CT- 
angiography. AAA was defined as an aorta with an antero-posterior diameter $>30 \mathrm{~mm}$.

The study was approved by the local medical ethical committees of all participating centres and conformed with the principles outlined in the declaration of Helsinki. ${ }^{20}$ All patients gave written informed consent. Patients with acute infections, recent antibiotic use ( $<3$ months), recent vascular surgery ( $<3$ months), concomitant inflammatory disorders and malignancies were excluded.

\subsubsection{Extent of atherosclerotic disease}

In order to determine the extent of atherosclerotic disease, the documented cardiovascular, cerebrovascular, and peripheral vascular morbidity as well as the presence/absence of AAA was taken into consideration. An 'extent of atherosclerosis score' was developed ascribing a point for every vascular territory (coronary, cerebral, peripheral, and aorta) affected by symptomatic atherosclerotic disease. Since patients with PAD were included, the peripheral vascular territory was considered affected in all patients. The coronary vascular territory was considered affected in case of a history of myocardial infarction (MI), angina pectoris (AP), percutaneous transluminaly coronary angioplasty ( $P T C A)$ and/or coronary artery bypass grafting (CABG). The cerebral territory was considered affected in case of a history of stroke, transient ischemic attack (TIA), amaurosis fugax and/or carotid endarterectomy. Finally, the aorta was regarded affected in case of a (history of) AAA (aortic diameter $>30 \mathrm{~mm}$ ) and/or aortic reconstruction for AAA. The sum, ranging from 1 (only PAD) to 4 (all vascular territories affected) was considered as an indication of the extent of atherosclerotic disease.

\subsubsection{DNA Extraction}

Genomic DNA was extracted from peripheral blood mononuclear cells

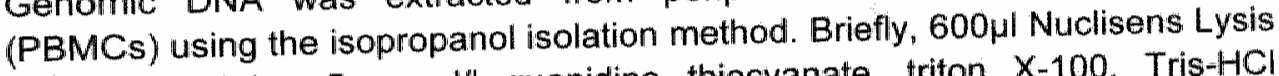
buffer containing $5 \mathrm{mmol} / /$ guanidine thiocyanate, triton $X-100$, Tris- $\mathrm{HCl}$ (Organon Teknika, Boxtel, The Netherlands) and $1 \mu$ lglycogen, was added to $100 \mu \mathrm{l} \mathrm{PBMCs}$ in phosphate-buffered saline. The DNA pellets were dissolved in $\mathrm{T} 10\left(10 \mathrm{mM}\right.$ Tris- $\mathrm{HCl}, \mathrm{pH} 8.0$ ) and stored at $-20^{\circ} \mathrm{C}$ until further analysis.

\subsubsection{Genotyping of TLR4 and CD14}

An in-house developed PCR-based restriction fragment-length polymorphism assay was used to detect the $A>G$ missense mutation at nucleotide $896 \mathrm{bp}$ (amino acid Asp299Gly) in the human TLR4 gene (NCBI SNP CLUSTER ID: rs4986790). ${ }^{21}$ Digestion with $\mathrm{Ncol}$ (Invitrogen Live Technologies BV, Breda, 
The Netherlands) and separation on an $4.5 \%$ agarose gel containing $0.1 \%$ ethidium bromide (BIOzymTC, Landgraaf, The Netherlands) of the $102 \mathrm{bp}$ PCR product (primerS 5'-AGC ATA CTT AGA CTA CTA CCT CCA TG-3' and 5'-TTा ACC CTT TCA ATA GTC ACA CTC A-3') yielded fragments of $102 \mathrm{bp}$ (Aallele) and/or 80 and 22 bp (G-allele).

The C>T substitution in the proximal CD14 promator region at position -260 (NCB| SNP CLUSTER ID: rs2569190) was analysed with an in-house developed PCR assay using the primers, 5'-TCA CCT CCC CAC CTC TCT T3'(sense) and 5'-CCT GCA GAA TCC TTC CTG TT-3'(antisense) (Invitrogen Live Technologies BV, Breda, The Netherlands). The 107bp amplification products were digested with Hae III (New England Biolabs, England, UK) yielding either two fragments of 83 and $24 \mathrm{bp}$ (C-allele) and/or an intact fragment ( $T$-allele) of $107 \mathrm{bp}$, respectively.

\section{3 .5 Statistics}

The $\chi^{2}$-test was used for comparison of TLR4 +896 A>G and CD14-260 C>T genotype frequencies, carrier trait analyses (combined effect of the TLR4 and $C D 14$ polymorphisms analyzed), and prevalence of risk factors between patient groups. A trend analysis was used to investigate if specific CD14 or TLR4 allele frequencies increased with the number of vascular territories affected by atherosclerosis. Multivariate logistic regression models were computed using extensive atherosclerotic disease' (i.e., $>2$ vascular territories affected by atherosclerosis) as dependent variable and entering in a stepwise, forward conditional fashion, cardiovascular risk factors, TLR4,CD14 SNPS, and the $T L R 4 C D 14$ SNP interaction variable as independent variables. SPSS 10.0 for Windows (SPSS Inc., Chicago, IL, USA) was used for the statistics.

\subsection{Results}

\subsubsection{Patient characteristics}

A total of 607 Dutch Caucasian PAD patients were analysed. Patient characteristics are given in Table 7.1. The patients had an atherosclerotic risk factor profile, as seen in this table. It also became evident that the patients suffered from extensive atherosclerotic disease, since 273 patients $(45 \%)$ presented with manifestations of atherosclerosis in at least one additional vascular territory besides peripheral, thus illustrating the systemic nature of atherosclerosis. 
Tiable 7.1 Patient characteristics $(n=607)$.

\begin{tabular}{lc}
\hline Mean (SD) Age in years & $65(10)$ \\
Female/male & $184(30 \%) / 423(70 \%)$ \\
Smoking: $^{\text {Dislipidemiat }}$ & $476(78 \%)$ \\
Hypertension $^{\text {t }}$ & $503(83 \%)$ \\
Diabetes $^{\text {On }}$ & $363(60 \%)$ \\
One vascular territory affected & $138(23 \%)$ \\
Two vascular territories affected & $334(55 \%)$ \\
Three vascular territories affected & $204(34 \%)$ \\
Four vascular territories affected & $67(11 \%)$ \\
\hline
\end{tabular}

${ }^{a}$ currently smoking or stopped $<10$ years; ${ }^{b}$ fasting chollesterol level $>5.9 \mathrm{mmol} / \mathrm{and}$ anor triglyceride level $>1.95 \mathrm{mmol} / \mathrm{l}$ and/or the use of antidislipidiemic medication; "systolic blood pressure $>160 \mathrm{mmHg}$ and/or diastolic blood pressure $>95 \mathrm{mmHg}$ and/or the use of antihypertensive medication; "fasting glucose level $>7 \mathrm{mmol} / /$ or the use of antiglycemic medication or insulin.

\subsubsection{TLR 4 and CD14 genotyping}

Table 7.2 shows the genotype, carrier and allele frequency of the TLR4 +896 $A>G$ SNP in the PAD patients and the healthy controls ${ }^{21,22}$. The overall prevalence of this SNP in our PAD patients was approximately $10 \%$. However, among our patients there seemed to be a significant relation between TLR4 $+896 \mathrm{G}$ allele carrier-ship and extent of atherosclerotic disease. The average extent of atherosclerosis score was higher in patients with a polymorph allele compared to patients homozygous for the wild-type TLR-4 allele (1.8 vs. 1.5 , $P=0.011$, Mann-Whitney U Test). TLR4 $+896 \mathrm{G}$ carriers had significantly more frequently (OR: $2.2, P=0.020, \chi^{2}$ test) extended atherosclerotic disease ( $>2$ vascular territories affected).

Table 7.2 Genotype, allele- and carrier frequencies of the TRR4 $+896 A>G$ alleles in atherosclerotic patients.

\begin{tabular}{lrrrrrrr}
\hline & & \multicolumn{3}{c}{ Genotype } & Carrier & Allele \\
\cline { 5 - 7 } & & AA & AG & GG & Frequency & frequency \\
\hline 1 affected vascular territory (PAD only) & 334 & 307 & 27 & 0 & $8.1 \%$ & $4.0 \%$ \\
2 affected vascular territories & 204 & 180 & 23 & 1 & $11.8 \%$ & $6.1 \%$ \\
3. affected vascular territories & 67 & 54 & 13 & 0 & $19.4 \%$ & $9.7 \%$ \\
4. affected vascular territories & 2 & 2 & 0 & 0 & $0.0 \%$ & $0.0 \%$ \\
Total & 607 & 543 & 63 & 1 & $10.5 \%$ & $5.4 \%$ \\
\hline
\end{tabular}

Extended atherosclerotic disease $>2$ vascular territories affected $(n=69)$ is significantly associated with TLR4 $+896 G$ carrier-ship (OR: $2.22, P=0.020, \chi^{2}$ test). "Trend anallysis: $\pi R R 4+896$ G-allele frequency increases with the number of vascular territories affected ( 1 to 2 to $3+4)$ : P-trend 0.0074 $\left(x^{2}=7.2\right)$.

Trend analysis showed that the TLR4 +896 Gallele frequency statistical significantly increased with the number of vascular territories affected by 
atherosclerosis (see Table 7.2): $8.1 \%$ in patients with one affected vascular territory, $11.8 \%$ in patients with two affected territories, and $18.8 \%$ in patients with three or four affected vascular territories (P-trend 0.0074). Since only two patients had four affected vascular territories they were grouped together with those with three affected territories.

In a multivariate logistic regression model the association between the $T L R 4$ +896 A $>G$ SNP and extended atherosclerotic disease ( $>2$ vascular territories affected) persisted after correction for relevant confounders (OR: $2.1, P=0.048$, Table 7.3)

Table 7.3 Stepwise forward computed multivariate logistic regression model demonstrating the relation between TLR4 $\$ 996 \mathrm{G}$ carrier-ship and extent of atherosclerotic disease. Dependent variable: 'extensive atherosclerotic disease' (i.e., $>2$ vascular territories affected). $n=607$.

\begin{tabular}{lccccc}
\hline Independent variable & $\mathrm{B}$ & $\mathrm{SE}$ & $\mathrm{P}$ & $\mathrm{OR}$ & $95 \% \mathrm{Cl}$ \\
\hline Asp299Gly allele & 0.735 & 0.371 & 0.048 & 2.085 & $1.01-4.31$ \\
Hypertension & 1.205 & 0.352 & 0.001 & 3.338 & $1.68-6.65$ \\
Age & 0.639 & 0.300 & 0.033 & 1.895 & $1.10-3.41$ \\
Constant & -3.251 & 0.362 & 0.001 & & \\
\hline
\end{tabular}

Variables excluded from the equation were: sex, smoking, diabetes, hypercholesterolemia, and positive family history.

The CD14 polymorphism was very common (Table 7.4). Approximately $22 \%$ of patients had the TT-genotype and about $50 \%$ were heterozygous for the CD14 polymorphism. In contrast to the TLR4 polymorphism, the CD14 SNP was not related to the extent of atherosclerotic disease in univariate analysis.

Table 7.4 Allele and carrier frequencies of the pollymorphic CD14 (-260)C $>T$ allele in atherosclerotic patients.

\begin{tabular}{lrrrrrrc} 
& \multicolumn{3}{c}{ Genotype } & Carrier & Allele \\
& \multicolumn{1}{c}{$\mathrm{N}$} & $\mathrm{CC}$ & $\mathrm{CT}$ & \multicolumn{1}{c}{ fT } & frequency & frequency \\
\hline 1 affected vascular territory (PAD only) & 334 & 88 & 169 & 77 & $73.7 \%$ & $48.4 \%$ \\
2 affected vascular territories & 204 & 52 & 112 & 40 & $74.5 \%$ & $47.1 \%$ \\
3 affected vascular territories & 67 & 16 & 35 & 16 & $76.1 \%$ & $35.0 \%$ \\
4 affected vascular territories & 2 & 0 & 2 & 0 & $100 \%$ & $50.0 \%$ \\
Total & 607 & 156 & 318 & 133 & $74.3 \%$ & $48.1 \%$ \\
\hline
\end{tabular}

Extent of atherosclerotic disease was not related to CD 14 polymorphism. 


\subsubsection{Carrier trait analysis}

Finally we performed a CD14-TLR4 carrier trait analysis in relation to the extent of atherosclerotic disease. Forty-four patients were carrier of the $T L R 4 G$-allele in combination with the CD14T-allele, and 14 patients had the $T L R 4$ Gallele in combination with the CD14 TT genotype. Carrier trait analyses for the TLR4 and CD14 SNPs studied showed a trend towards association with extent of atherosclerotic disease, but this association failed to reach statistical significance in univariate logistic regression analyses (Table 7.5).

Table 7.5 Association between the carrier trait of TLR4- and CD14-SNP and extent of atherosclerotic disease.

\begin{tabular}{|c|c|c|c|c|}
\hline \multirow[t]{2}{*}{ Extent of atherosclerotic disease } & \multicolumn{2}{|c|}{$\begin{array}{c}\text { TLR4-CD14 } \\
\times G-\times T^{\mathrm{a}}\end{array}$} & \multicolumn{2}{|c|}{$\begin{array}{c}\text { TLR4-CD14 } \\
\times 0-T^{6}\end{array}$} \\
\hline & - & + & - & + \\
\hline$\leq 2$ territories affected $(n=538)$ & 503 & 35 & 528 & 10 \\
\hline$>2$ territories affected $(n=69)$ & 60 & 9 & 65 & 4 \\
\hline Total & 563 & 44 & 593 & 14 \\
\hline
\end{tabular}

a Univariate logistic regression analysis: $P=0.054, O R: 2.156(0.99-4.70)$; ${ }^{b}$ Univariate logistic regression analysis: $P=0.052$, OR: $3.249(0.99-10.67)$

However, when in the multivariate logistic regression model cardiovascular risk factors, carriership of the TLR4 Gallele, the CD14 TT genotype, and the combination of TLR4 G-allele and CD14 TT genotype were entered as independent variables, only the interaction variable TLR4 G-allel-CD14 TT genotype (OR: 4.2, $P=0.031$ ) survived as independent predictor of 'extensive atherosclerotic disease' (i.e. $>2$ vascular territories affected by atherosclerosis; Table 7.6).

Table 7.6 Stepwise forward computed multivariate logistic regression model demonstrating the relation between the carrier trait of $T L R 4+896 G$ allele carriership (XG) and CD14 $(-260)$ TT genotype (TT) and extent of atherosclerotic disease. Dependent variabie: "extensive atherosclerotic disease" (i.e., $>2$ vascular territories affected). $N=607$.

\begin{tabular}{lccccc}
\hline Independent variable & $\mathrm{B}$ & $\mathrm{SE}$ & $\mathrm{P}$ & $\mathrm{OR}$ & $95 \% \mathrm{Cl}$ \\
TLR4(xG)-CD $14(\mathrm{TT})$ & 1.434 & 0.665 & 0.031 & 4.194 & $1.14-15.44$ \\
hypertension & 1.184 & 0.352 & 0.001 & 3.269 & $1.64-6.52$ \\
age & 0.687 & 0.303 & 0.023 & 1.988 & $1.10-3.60$ \\
constant & -3.210 & 0.359 & 0.001 & & \\
\hline
\end{tabular}

Variables excluded from the equation were: sex, smoking, diabetes, hypercholesterolemie, positive family history, TLR4 +896 G allele carrier-ship, and CD14 $(-260)$ TT genotype. 


\subsection{Discussion}

In the present study we assessed the effect of the common $T L R 4+896$ A>G and $C D 14(-260) C>T$ polymorphisms on the extent of atherosclerosis in patients with peripheral arterial disease. Using a multivariate logistic regression model, our data showed that the carrier trait profile TLR4 G-allele in combination with the CD14 TT-genotype had the strongest effect on the extent of atherosclerotic disease.

In the present study, the overall TLR4 $+896 G$ allele frequency in Dutch Caucasian patients with peripheral arterial disease was approximately $10 \%$. This was comparable to our earlier reported $T L R 4+896 \mathrm{G}$ allele frequencies in Dutch Caucasian women with or without tubal pathology, ${ }^{22}$ to the $T L R A+896 G$ allele frequencies in male patients with angiographically documented coronary atherosclerosis ${ }^{11}$ and to those in patients with meningococcal disease reported by Read et $a l^{23}$ Surprisingly, we did observe an interesting, significant partitioning in $T L R 4+896 \mathrm{G}$ allele frequency, being approximately $8 \%$ in patients with PAD only, $12 \%$ in patients with 2 vascular territories affected by atherosclerosis, and being approximately $19 \%$ in patients with extensive atherosclerotic disease affecting 3 vascular territories. This represented a significant trend $\left(\chi^{2}\right.$ for trend $\left.=7.6, P=0.0074\right)$. This seems contradictory to earlier reports showing that the TLR4 polymorphism protected against the development of early carotid plaque ${ }^{8}$ and unstable coronary events. ${ }^{10}$ In contrast to these earlier studies, we did not limit our analysis of the relation between TLR4 SNPs and atherosclerosis to coronary events or carotid plaques only. Instead, in order to take into account the systemic nature of atherosclerosis we considered the clinical manifestation of atherosclerosis in the coronary, cerebral and peripheral circulation, and aorta. The early steps in atherogenesis often represent a response of the innate immune system to stimuli such as the accumulation and modification of lipoproteins in the arterial intima, whereas the progression of atherosclerosis depends on inappropriate activation of the innate and acquired immune system by both endogenous and exogenous stimuli. ${ }^{2}$ The $T L R 4+896$ A $>G$ polymorphism may very well be associated with delayed development of early atherosclerotic plaques theoretically through a blunted innate response, thereby explaining the inverse relationship observed between this polymorphism and carotid intima-media thickness and ultrasonographically detected, asymptomatic carotid plaque. ${ }^{B}$ However, once the initial steps in atherogenesis have occurred, as is the case in PAD patients with an average age of 65 years, this TLR4 polymorphism involved in the clearance of endogenous and exogenous (bacterial) atherogenic stimuli, may be associated with exacerbated development of advanced atherosclerotic lesions, as has been shown in our study. The interaction between the TLR4 polymorphism and atherosclerosis may also be influenced by the patient's pharmacotherapy. Boekholdt, et al. showed that the 
TLR4 $+896 \mathrm{G}$ allele had a significantly lower risk of cardiovascular events only for pravastatine users. Furthermore, the pravastatine related risk reduction was more pronounced for $T L R 4+896 \mathrm{G}$ allele carriers. ${ }^{11}$

The CD14 promotor region polymorphism has been reported to enhance transcriptional activity of the CD14 gene. ${ }^{24}$ The TT genotype is associated with higher serum levels of SCD14, increased density of CD14 on monocytes, higher prevalence of Chlamydia pneumoniae infections and enthanced chlamydia-stimulated TNF- $\alpha$ production. ${ }^{25,26}$ The $C D 14 \quad(-260) C>T$ polymorphism has been associated with carotid artery intima media thickness, ${ }^{12}$ increased stroke risk ${ }^{13}$ and acute myocardial infarction. ${ }^{14,15}$ In contrast, Ito et al. and Longobardo et al. showed no relation between this polymorphism and cerebrovascular disease ${ }^{16}$ or myocardial infarction, ${ }^{17}$ respectively. Likewise, using a nested case-control study within a large prospective cohort of apparently healthy individuals, Zee and co-workers demonstrated a lack of association between the CD14 (-260)C>T polymorphism and (thromboembolic) stroke. ${ }^{18}$ Similarly, among the patients with peripheral arterial disease in our study, the CD14 SNP was not related to the extent of atherosclerotic disease.

A considerable number of SNPs have been identified in innate immunity genes belonging to the TLR response pathway, among which 44 SNPs in TLR4 and 37 in CD14. ${ }^{27}$ Therefore, when analysing the role of specific SNPs in relation to severity of a specific disease, it is imperative to consider polymorphisms with functional implications that fit into a certain pathogenic paradigm. Otherwise, bearing in mind the considerable number of SNPs, there is a considerable possibility that statistically significant associations are described that may be based on chance only. Although it is accepted that the CD14 $(-260) C>T$ polymorphism is functional, questions remain regarding the functionality of the $T L R 4+896$ A $>G$ polymorphism. Even though the homozygous genotype is functional, ${ }^{7}$ the heterozygous genotype which has been associated with atherosclerotic disease in several studies, presents no deficit in the recognition of LPS. ${ }^{28}$ However, this does not exclude that the heterozygous genotype is functional for other agonists which have not been tested on functionality in this heterozygous type, including human and chlamydial heat shock protein 60 . Considering the complexity of the innate immune system and it's high degree of genetic variation, a significant number of collateral pathways may exist for innate immune responses, which differ in their cofactor requirements and their pattern recognition specificities. Ideally, all pathways should be taken into consideration and carrier traits instead of individual SNPs should be regarded when studying genetic predisposition of the innate immune system in relation to atherosclerosis and other inflammatory diseases which are all multifactorial and polygenic diseases. To illustrate this, it has recently been shown that carriage of multiple pro-inflammatory polymorphisms conferred a greater risk of 
noncardia gastric cancers, with odds ratios increasing from 2.8 for one to 27.3 for more than 3 high risk SNPs. ${ }^{19}$ In this study we analysed the combined effect of polymorphisms in two components of the innate immune system on the extent of atherosclerotic disease in patients with advanced atherosclerosis. Intriguingly, the combination of the CD14 SNP resulting in transcriptional activity of the CD14 gene ${ }^{24}$ and carriership of the $T L R 4+896 \mathrm{G}$ allele was related to the extent of atherosclerotic burden in patients with PAD. Failure to take into consideration SNPs in both genes may account for the contradictory results when CD14 and TLR4 polymorphisms were studied individually with regard to atherosclerosis. Similarly, failure to correct for relevant cardiovascular risk factors is another important aspect that has to be taken into account in this kind of studies. In our population, the significance of the association between the combined TLR4-CD14 carrier trait and extent of atherosclerotic diseased was strengthened after correction for relevant risk factors (Table 7.5).

In conclusion, considering the importance of (innate) immune responses in the development of atherosclerosis, our data provide an explanation for interindividual susceptibility to atherosclerosis based on genetic variability of a combination of genes involved in innate immune regulation. A carrier trait of a combination of TLR4 and CD14 SNPS, rather than each polymorphism individually, was associated with extent of atherosclerotic disease using a multivariate logistic regression model. 


\subsection{References}

1. Ross R. Atherosclerosis--an inflammatory disease. N Engl J Med. 1999; 340:115-26.

2. Hansson GK, Libby $P$, Schonbeck $U$, Yan $Z Q$. Innate and adaptive immunity in the pathogenesis of atherosclerosis. Circ Res. 2002; 91:281-91.

3. Leinonen $M$, Saikku $P$. Evidence for infectious agents in cardiovascular disease and atherosclerosis. Lancet Infect Dis. 2002; 2:11-7.

4. Medzhitov R, Preston-Hurlburt P. Janeway CA, Jr. A human homologue of the Drosophila Toll protein signals activation of adaptive immunity. Nature. 1997; 388:394-7.

5. Poltorak A, Ricciardi-Castagnoli $P$, Citterio $S$, Beutler $B$. Physical contact between lipopolysaccharide and toll-like receptor 4 revealed by genetic complementation. Proc Natt Acad Sci USA. 2000; 97:2163-7.

6. Werling $D_{n}$, Jungi TW. TOLL-like receptors linking innate and adaptive immune response. Vet Imrnumol Immunopathol. $2003 ; 91: 1-12$.

7. Arbour NC, Lorenz. $E_{n}$ Schutte $B_{0}$ et al. TLR4 mutations are associated with endotoxin hyporesponsiveness in humans. Nat Genet. 2000; 25:187-91.

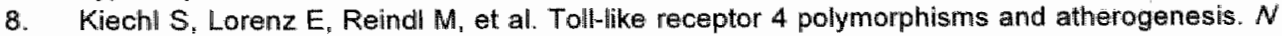
Engl J Med. 2002; 347:185-92.

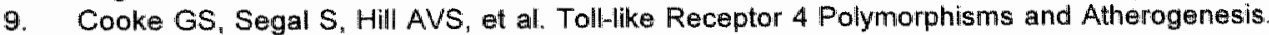
NEngi J Med. 2002; 347:1978-80.

10. Ameziane $N$, Beillat $T$, Verpillat $P$, et al. Association of the Toll-like receptor 4 gene Asp299Gly polymorphism with acute coronary events. Arterioscler Thromb Vasc Biol. 2003; 23:e61-4.

11. Boekholdt $S M$, Agema WR, Peters RJ, et al. Variants of toll-like receptor 4 modify the efficacy of statin therapy and the risk of cardiovascular events. Circulation. 2003:107:2416-21.

12. Risley $P$, Jerrard-Dunne $P$, Sitzer $M$, Buehler $A$, von Kegler $S$, Markus HS. Promoter polymorphism in the endotoxin receptor (CD14) is associated with increased carotid atherosclerosis only in smakers: the Carotid Atherosclerosis Progression Study (CAPS). Stroke. 2003; 34:600-4.

13. Lichy $C$, Meiser H, Grond-Ginsbach C, Buggle F, Dorfer C, Grau A. Lipopolysaccharide receptor CD14 polymorphism and risk of stroke in a South-German population. J Neurol $2002 ; 249: 821-3$.

14. Hubacek JA, Rothe $G$, Pit'ha $J$, et al. $C(-260)-\rightarrow$ T polymorphism in the promoter of the CD14 monocyte receptor gene as a risk factor for myocardial infarction. Circulation. 1999,99: $3218-20$.

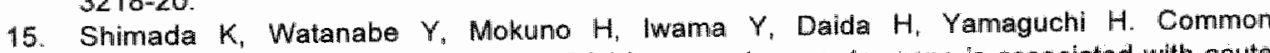
polymorphism in the promoter of the $\mathrm{CD} 14$ monocyte receptor gene is associated with acute myocardial infarction in Japanese men. Am J Cardiol. 2000; 86:682-4, A8.

16. Ito $D$, Murata $M$, Tanahashi $N$, et al. Polymorphism in the promoter of lipopolysaccharide receptor $C D 14$ and ischemic cerebrovascular disease. Stroke. 2000; 31:2661-4.

17. Longobardo MT, Cefalu $A B$, Pezzino $F$, et al. The $C(-260)>T$ gene polymorphism in the promoter of the CD14 monocyte receptor gene is not associated with acute myocardial infarction. Clin Exp Med. 2003;3:161-5.

18. Zee RY, Bates D, Fidker PM. A prospective evaluation of the CD14 and CD18 gene polymorphisms and risk of stroke. Stroke. 2002; 33:892-5.

19. El-Omar EM, Rabkin CS, Gammon MD, et al. Increased risk of noncardia gastric cancer associated with proinflammatory cytokine gene polymorphisms. Gastroenterology. 2003; 124:1193-201.

20. World Medical Association Declaration of Helsinki. Recommendations guiding physicians in biomedical research involving human subjects. Cardiovasc Res. 1997; 35:2-3.

21. Morre SA, Murillo LS, Spaargaren J, Fennema HS, Pena AS. Role of the toll-like receptor 4 Asp299Gly polymorphism in susceptibility to Candida albicans infection. J Intect Dis. 2002 186:1377-9 
22. Morre SA, Murillo LS, Bruggeman CA, Pena AS. The role that the functional Asp299Gly polymorphism in the toll-like receptor-4 gene plays in susceptibility to Chlamydia trachomatisassociated tubal infertility. Infect Dis. 2003; 187,341-2.

23. Read $\mathrm{RC}$. Pullin $\mathrm{d}$, Gregory $\mathrm{S}$, et al. A functional polymorphism of tolltike receptor 4 is not associated with likelihood or severity of meningococcal disease. I/nfect Dis. 2001;184:640-2.

24. LeVan TD, Bloom JW. Bailey TJ, et al. A common single nucleotide polymorphism in the CD14 promoter decreases the affinity of $\mathrm{Sp}$ protein binding and enhances transcriptional activity. Jlmmunol. 2001; 167:5838-44.

25. Eng HL, Chen CH, Kuo CC, WU JS, Wang CH, Lin TM. Association of CD14 promoter gene polymorphism and Chlamydia pneumoniae infection. I infect Dis. 2003; 188:90-7.

26. Eng $\mathrm{HL}$, Wang $\mathrm{CH}$, Chen $\mathrm{CH}$, Chou MH, Cheng $\mathrm{CT}$, Lin TM. A. CD14 promotor polymorphism is associated with CD14 expression and Chlamydia-stimulated TNFalpha production. Genes Immun. 2004; 5:426-30.

27. Vercelli D. Genetic polymorphism in allergy and asthma. Curr Opin Immuno/ 2003;15:609-13.

28. Erridge C. Stewart J, Poxton IR. Monocytes heterozygous for the Asp299Gly and Thr399lle mutations in the Toll-like receptor 4 gene show no deficit in lipopolysaccharide signalling. $f$ Exp Med. 2003; 197:1787-91. 


\section{Section 5}

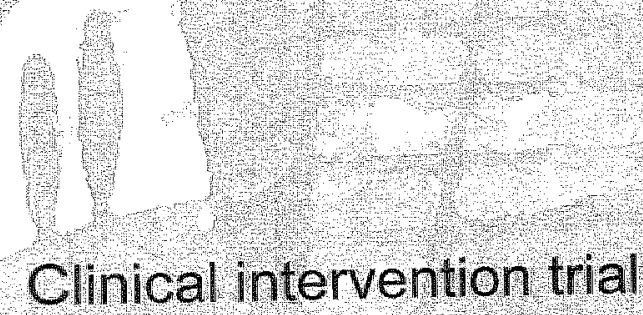




\section{Chapter 8}

Secondary Prevention of Atherosclerosis through Chlamydia pneumoniae Eradication (SPACE trial): a randomised clinical trial in patients with peripheral arterial disease

Vainas $T$, Stassen FR, Schurink GW, Tordoir $\mathrm{JH}$, Welten RJ, van den Akker $L H$, Kurvers HA, Bruggeman CA, Kitslaar PJ Eur J Vasc Endovasc Surg. 2005; 29:403-411 


\title{
8.1 Abstract
}

\author{
Background \\ Sero-epidemiological and animal experimental studies suggest that Chlamydia pneumoniae \\ infections play an important role in the development of atherosclerosis. Clinical trials have shown \\ contradictory results regarding the efficacy of antibiotics to prevent atherosclerosis-related \\ complications in patients with coronary artery disease. Our aim was to study the effect of a short \\ course of azithromycine on the incidence of cardiovascular events and peripheral vascular function \\ in pratients with stable peripheral arterial disease (PAD).
}

\section{Materials and methods}

Five hundred and nine PAD-patients were randomised to receive a 3-day course of azithromycin (500mg daily) or placebo, with 2 years follow-up. Chlamydia pneumoniae serology was determined at baseline. Clinical endpoints were death (all cause mortality), coronary events (myocardial infarction, unstable angina, and/or coronary revascularization procedures), cerebral events (stroke, transient ischemic attack, and/or carotid endarterectomy) and peripheral arterial complications (increased PAD-symptoms with decreased ankle-brachial pressure index (ABPI), and/or peripheral revascularization procedures). Hemodynamic endpoint was a 0.1-point decrease of ABPI after 12 months.

\section{Results}

Five hundred and nine patients (160 women) with an atherosclerotic risk factor profile were randomised, 257 patients to azithromycine and 252 to placebo. Four hundred and forty nine patients $(88 \%)$ had intermittent claudication and $60(12 \%)$ had critical limb ischemia. By 24 -month follow-up, 182 patients $(36 \%$ ) developed 252 complications ( 45 deaths, 34 coronary events, 34 cerebral events and 139 peripheral arterial complications). Chlamydia pneumoniae IgA titres were associated with the development of cardiovascular events. Nevertheless, the number of complications (131 in the azithromycin group vs. 121 in the placebo group) and the number of patients that developed complications $(98(38 \%)$ in the azithromycin vs. $84(33 \%)$ in the placebo group) was comparable in both treatment groups. Life table analysis showed no effect of azithromycin on survival. Azithromycin had no effect on the hemodynamic endpoint.

\section{Conclusion}

A short-term course of azithromycine offers no benefits for survival or improved ankle pressure in PAD-patients. 


\subsection{Introduction}

Recently it has become evident that atherosclerosis is an inflammatory disease. "Consequently, infections triggering immune responses, may play an important role in the initiation or propagation of atherosclerosis. Already in the early $20^{\text {th }}$ century, before the inflammatory nature of atherosclerosis became widely accepted, it had been suggested that infections may contribute to the development of atherosclerosis. ${ }^{2-4}$ However, it was not before 1978 that it had been proven experimentally that infections may lead to the development of atherosclerosis. ${ }^{5}$ Subsequently, it had been observed that acute (respiratory tract) infections were associated with acute coronary events, ${ }^{6,7}$ and especially that Chlamydia pneumoniae infections were associated with coronary artery disease. $^{8}$ The identification of Chlamydia pneumoniae in atherosclerotic plaques further supported the notion that Chlamydia pneumoniae infections may be associated with the development of atheroslerosis. ${ }^{9}$ The infection hypothesis really gained momentum when 2 groups independently reported that antibiotics may prevent cardiovascular events in patients with coronary artery disease. ${ }^{10,11}$ Since then, antibiotic trials conducted throughout the world showed contradictory results regarding the efficacy of antibiotics for prevention of atherosclerotic complications. Most of the studies showing favourable results were of small sample size, included patients with abdominal aortic aneurysms or peripheral arterial disease, or used surrogate endpoints such as flowmediated dilation. In contrast, 3 larger studies of patients with coronary artery disease demonstrated no beneficial effect of antibiotics in the prevention of acute coronary events and/or death. ${ }^{12-14}$

Peripheral arterial disease represents a manifestation of atherosclerosis affecting up to $20 \%$ of primary care attendees. ${ }^{15}$ The systemic nature of atherosclerosis is shown by the high prevalence of coronary and cerebral arterial disease in these patients. ${ }^{15}$ Considering the prevalence of PAD and the significant cardiovascular co-morbidity, this group of patients is very suitable to study the effect of interventions altering the progression of atherosclerosis, both in terms of clinically relevant events and in terms of easily accessible surrogate hemodynamic endpoints such as the ankle-brachial pressure index (ABPI).

Chlamydia pneumoniae is an obligate intracellular microbe showing a tropism for macrophages. The antichlamydial antibiotic azithromycin yields high intracellular macrophage concentrations after a 3 day course, that 10 days after the last dose still is in the bactericidal range $(>32 \mathrm{mg} / \mathrm{l}) .^{16}$ Furthermore compared to other macrolide antibiotics, such as roxithromycin, azithromycin has a better gastro-intestinal tolerability. ${ }^{17}$ Considering the above, we tested the hypothesis that, in PAD patients, a short course of azithromycin would reduce the subsequent incidence of atherosclerotic events of the coronary, 
cerebral and peripheral arterial circulation and would influence (changes in) ABPI.

\subsection{Materials and methods}

Patients with symptomatic peripheral arterial disease (intermittent cllaudication or critical limb ischemia) were recruited at the surgicall clinics of a university hospital and two affiliated teaching hospitals. Inclusion and exclusion criteria are given in Table 8.1. The study was approved by the medical ethics committees of all participating centres and conformed with the principles outlined in the declaration of Heisinki. ${ }^{18}$ All patients entered the study after giving written informed consent.

Table 8.1 Inclusion and exclusion criteria

\begin{tabular}{ll}
\hline Inclusion criteria & Symptomatic $P A D$ \\
& $A B P \mid<0.9$ or decrease of ankle pressure with $25 \mathrm{mmHg}$ after standardized \\
& ireadmill exercise \\
Exclusion criteria & Recent antibiotic use ( $<3$ months) \\
& Recent vascular (coronary, cerebral, peripheral) event ( $<6$ months) \\
& Recent vascular (cororiary, cerebral, peripheral) intervention $1<12$ months) \\
& Renal failure \\
& Liver failure \\
& Life expectancy $<2$ years \\
& Malignancy \\
Inflammatory co-morbidity
\end{tabular}

The study was designed as a randomised, double-blind, placebo controlled, secondary prevention trial of a short course of azithromycin ( 3 days) in patients with PAD. The hypothesis was that the antibiotic treatment would lead to a clinically significant, i.e., $50 \%$ reduction of the combined event rate. In order to calculate the required number of patients needed to show this effect, the data reported by Dormandy et al. were used. ${ }^{19}$ With an annual event rate of $15 \%$, 204 patients in every treatment group were needed to observe the desired effect after two years, with a power $(\beta)$ of 0.95 and a type I error $(\alpha)$ of 0.05 . To ensure sufficient events within two years, target recruitment was 500 patients.

At inclusion patients underwent physical examination. The presence of atherosclerotic risk factors was assessed and cardiac and cerebrovascular comorbidities were documented. The ABPI was measured in the supine position after a 15 minute rest period. The ankle pressure was measured in the posterior tibial and dorsal pedal artery. The highest ankle pressure was used to determine the ABPI.

After the baseline clinical and hemodynamic evaluation, venous blood was drawn and patients were randomised to receive a 3-day course of azithromycin 
(500mg daily) or an identically looking placebo. In order to assess drug tolerability and compliance, patients were asked to keep a 'treatment logbook'. The randomisation list was computer generated in blocks of 5 and randomisation was performed in 6 strata, i.e., three participating clinics by two clinical presentations (claudication or critical limb ischemia). Patients, attending surgeons and co-ordinating scientist were blinded for the experimental intervention.

\subsubsection{Outcomes}

The primary endpoint was the composite of "all cause mortality and/or any coronary/cerebral/peripheral arterial event". We selected all cause mortality as part of the primary outcome variable, as often the cause of death cannot be established clearly for patients dying outside the hospital. ${ }^{20}$

Coronary events included myocardial infarction (defined by chest pain, elevated cardiac enzymes, and/or new diagnostic q-waves in at least two contiguous leads), de novo unstable angina pectoris (defined by chest pain, supported by either ECG changes suggestive of ischemia or elevated level of cardiac enzymes, greater than normal but not diagnostic for myocardial infarction), and/or any coronary revascularization procedure (PTCA or coronary artery bypass grafting). A cerebral event was any stroke or transient ischemic attack (diagnosis based on clinical symptoms and characteristic changes on cerebral computed tomography and/or magnetic resonance imaging). A peripheral arterial event was defined as any episode of deteriorating symptoms (e.g. increased severity of ischaemic pain) that was accompanied by either a decrease in $A B P I$ of at least 0.1 points and/or by any peripheral revascularization procedure (PTA or reconstructive vascular surgery).

\subsubsection{Hemodynamic endpoint}

In addition to aforementioned clinical endpoints, changes in ABPI over a 12 month period were analysed. A change in $A B P I$ of at least 0.1 point was considered significant (significant increase or decrease).

\subsubsection{Chlamydia pneumoniae serology}

Chlamydia pneumoniae IgA titres were determined by a commercially available enzyme immunoassay (Labsystems, Finland) as previously described ${ }^{21}$ Titres were calculated from optical density readings according to the manufacturer's instructions and were expressed in enzyme immunounits (EIUs). Although no consensus has been reached so far regarding the definition of Chlamydia pneumoniae seropositivity. ${ }^{22}$ patients with an IgA titre $\geq 16$ EIUs were considered seropositive in view of previously published studies showing an 
association between Chlamydia pneumoniae seropositivity and atherosclerosis using this cut off point. ${ }^{23-25}$

\subsubsection{Statistics}

The $x^{2}$-test was used for analysis of dichotomous variables and the MannWhitney $U$ test for analysis of continuous variables. Wilcoxon signed ranks test was used to compare average ABPI at inclusion and at 12 months. KaplanMeier with log rank statistics was used for the analysis of event free survivals in both treatment groups. Analyses were carried out on an intention to treat basis. All statistics were performed on SPSS 10.0 for windows software package (SPSS Inc, Chicago, IL, USA).

\subsection{Results}

Five hundred and nine patients were randomised. As expected a high proportion of our patients had (multiple) conventional cardiovascular risk factors (Table 8.2). Efforts were made to assure that all patients received best medical (secondary preventive) treatment. This implies that all patients were given antiplatelet therapy, that patients with untreated hyperglycemia or hypertension were referred to a physician for serum glucose and blood pressure regulation, and that patients with cholesterol $>5 \mathrm{mmol} / \mathrm{l}$ were treated with statins. The randomisation yielded two comparable groups (azithromycin group: $n=257$; placebo group: $n=252$ ) with respect to the prevalence of cardiovascular risk factors (Table 8.2), severity of PAD (Table 8.3), type of vascular treatment at inclusion and degree of vascular co-morbidity (Table 8.3), baseline ABPI (Table 8.3) and Chlamydia pneumoniae serology (Table 8.4). Patients were followed for a median of 24 months (range: 1 - 44months).

Table 8.2 Patient characteristics

\begin{tabular}{|c|c|c|c|c|}
\hline & Total group & Azithromycin group & Placebo group & $\rho$ \\
\hline N & $509(100 \%)$ & $257(50.4 \%)$ & $252(49.6 \%)$ & ns \\
\hline Average age (SD), years & $64.9(9.7)$ & $64.4(9.9)$ & $65.5(9.7)$ & ns \\
\hline Male & $3.48(68 \%)$ & $178(69 \%)$ & $170(67 \%)$ & ns \\
\hline Femaie & $161(32 \%)$ & $79(31 \%)$ & $82(33 \%)$ & ns \\
\hline Cardiovas. Fam. History & $310(61 \%)$ & $148(58 \%)$ & $162(64 \%)$ & ns \\
\hline Smoking & $400(79 \%)$ & $206(80 \%)$ & $194(77 \%)$ & ns \\
\hline Dislipidemia $^{c}$ & $412(81 \%)$ & $210(82 \%)$ & $202(80 \%)$ & ns \\
\hline Hypertension $^{d}$ & $295(58 \%)$ & $149(58 \%)$ & $146(58 \%)$ & ns \\
\hline Diabetes & $143(28 \%)$ & $77(30 \%)$ & $66(26 \%)$ & nisi \\
\hline
\end{tabular}

a first degree relative with first ischemic cardiovascular event before age of $70 ;$; currently smoking or stopped <10 year ago; "fasting cholesterol hevel $>5.0 \mathrm{mmol} / \mathrm{l}$ and/or triglyceride level $>1.95$ mmolll and/or use of antilipemic medication:" systolic blood pressure $>160 \mathrm{mmHg}$ and/or diastolic blood pressure $>95 \mathrm{mmHh}$ and/or use of antihypertensive medication; " fasting glucose level $>7 \mathrm{mmol} / \mathrm{and}$ aror use of antiglycemic medication/insulin. ns; not significant. 
Table 8.3 Cardiovascular status of the PAD patients at inclusion. This table shows the degree of $P A D, A B P I$, the planned vascular treatment and the cardiovascular co-morbidity of the patients at inclusion in the study.

\begin{tabular}{lrrrr}
\hline & Total & Azithromycin & Placebo & $P$ \\
\hline $\begin{array}{l}\text { Degree of PAD (Fontaine class) } \\
\text { Claudication (Fontaine II) }\end{array}$ & $449(88 \%)$ & $227(88 \%)$ & $222(88 \%)$ & $\mathrm{ns}$ \\
Critical limb ischemia (Fontaine IIVIV) & $60(12 \%)$ & $30(12 \%)$ & $30(12 \%)$ & $\mathrm{ns}$ \\
Averagle (SD) ABPI & $0.63(0.18)$ & $0.63(0.18)$ & $0.62(0.18)$ & $\mathrm{ns}$ \\
Vascular intervention plan at inclusion: & & & & \\
Conservative & $344(68 \%)$ & $178(69 \%)$ & $166(66 \%)$ & $\mathrm{ns}$ \\
Balloon Angioplasty (PTA) & $92(18 \%)$ & $40(16 \%)$ & $52(21 \%)$ & $\mathrm{ns}$ \\
Reconstructive vascular surgery & $73(14 \%)$ & $39(15 \%)$ & $34(13 \%)$ & $\mathrm{ns}$ \\
Vascular co-morbidity: & & & & \\
CAD & $163(32 \%)$ & $79(31 \%)$ & $84(33 \%)$ & $\mathrm{ns}$ \\
CVD & $76(15 \%)$ & $41(16 \%)$ & $35(14 \%)$ & $\mathrm{ns}$ \\
AAA & $50(10 \%)$ & $24(9 \%)$ & $26(10 \%)$ & $\mathrm{ns}$ \\
Combined CAD \& CVD & $36(7 \%)$ & $18(7 \%)$ & $18(7 \%)$ & $\mathrm{ns}$ \\
\hline
\end{tabular}

CAD: coronary artery disease; CVD: cerebrovascular disease; $A A A$ : abdominal aortic aneurysm; PAD: peripheral arterial disease; $\mathrm{ABPI}$ : ankle-brachial pressure index; ns: not significant.

Among the patients, $88 \%$ suffered from intermittent claudication and $12 \%$ had critical limb ischemia, i.e., resting pain and/or ischemic tissue loss (Tabie 8.3). The baseline treatment plan was conservative in the majority of cases (Table 8.3). Approximately one third of the patients were, at inclusion, scheduled to undergo an early intervention, either catheter based (18\%) or vascular surgery $(14 \%)$, that was not considered a peripheral arterial endpoint. A significant proportion of patients suffered from cardiovascular co-morbidities, i.e., 32\% had co-existent coronary artery disease, $15 \%$ had cerebrovascular disease and $10 \%$ were diagnosed with or had been treated for an abdominal aortic aneurysm. The average (SD) ABPI was $0.63(0.18)$. The average (SD) Chlamydia pneumoniae IgA titre was $28(30)$ ElUs and $52 \%$ of patients were considered seropositive (having an IgA>16 EIUs) (Table 8.4).

Table 8.4 Chlamydia pneumoniae lgA titres and seropositivity.

\begin{tabular}{lcccc} 
& $\begin{array}{c}\text { Entire population } \\
N=509\end{array}$ & $\begin{array}{c}\text { Azithromycin } \\
N=257\end{array}$ & $\begin{array}{c}\text { Placebo } \\
N=252\end{array}$ & $p$ \\
\hline Awerage (SD) lgA, ElUS & $27.6(30.8)$ & $26.6(28.7)$ & $28.7(32.8)$ & $0.86^{\circ}$ \\
$N(\%)$ lgAt & $265(52)$ & $139(54)$ & $126(50)$ & $0.49^{\circ}$ \\
\hline
\end{tabular}

* Mann-Whitrey $U$ test. ${ }^{2}$-test. ElU. Enzyme Immuno Units; lgAt indicates Chamydia preumoniae IgA seropositivity (lgA>16 ElUs). 
Azithromycin was well tolerated by the patients and self-reported compliance was excellent. Approximately $95 \%$ of patients completed the assigned treatment, i.e., $242 / 257$ (94\%) azithromycin treated patients and 242/252 (95\%) placebo treated patients. Fifteen patients in the azithromycin group and 10 patients in the placebo group discontinued treatment mainly due to (mild) gastro-intestinal complaints (diarrhea, nausea, vomiting, flatulence, stomachpain). One patient in the azithromycin group developed a skin rash.

\subsubsection{Follow-up, cardiovascular events and azithromycin}

In total, 182 patients ( $36 \%$ ) developed 252 events during follow-up (Table 8.5). Thirty-three patients $(6 \%)$ developed 34 coronary events, 33 patients $(6 \%)$ had 34 cerebrovascular events, 108 patients $(21 \%)$ developed 139 peripheral arterial events and 45 patients $(9 \%)$ died. Neither the total number of cardiovascular complications, nor the number of patients developing an event differed between groups. Ninety-eight patients $(38 \%)$ treated with azithromycin developed 131 complications vs. 84 patients (33\%) developing 121 cardiovascular events in the placebo group (Mann-Whitney $U$ test for comparison of total number of events, $P=0.37$, and $\chi^{2}$-test for comparison of fractions of patients reaching the combined endpoint, $P=0.26$ ). In addition, the fraction of patients developing multiple events did not differ between either group ( $\chi^{2}$-test, $P=0.57$ ). Cumulative freedom from the combined endpoint (death and/or any cardiovascular event, Figure 8.1) or from death, coronary, cerebrovascular, or peripheral event separately was not influenced by azithromycin (Kaplan Meier with Log rank test, $P=0.32$ for survival differences in the combined endpoint).

Table 8.5 Follow-up data regarding the effect of azithromycin on cardiovascular and hemodynamic endpoints.

\begin{tabular}{|c|c|c|c|c|c|c|}
\hline & \multicolumn{2}{|c|}{ Azithromycin group } & \multicolumn{2}{|c|}{ Placebo group } & \multirow[t]{2}{*}{$P^{A}$} & \multirow[t]{2}{*}{$P^{b}$} \\
\hline & $\begin{array}{c}N \\
\text { events }\end{array}$ & $\begin{array}{c}N(\%) \\
\text { patients }\end{array}$ & $\begin{array}{c}\mathrm{N} \\
\text { events }\end{array}$ & $\begin{array}{c}N(\%) \\
\text { patients }\end{array}$ & & \\
\hline Coranary events & 19 & $19(7)$ & 15 & $14(6)$ & 0.41 & 0.40 \\
\hline Cerebral events & 18 & $17(7)$ & 16 & $16(6)$ & 0.75 & 0.76 \\
\hline Peripheral events & 74 & $58(23)$ & 65 & $50(20)$ & 0.46 & 0.45 \\
\hline Death & 20 & $20(8)$ & 25 & $25(10)$ & 0.40 & 0.40 \\
\hline All ewents & 131 & $98(38)$ & 121 & $84(33)$ & 0.37 & 0.26 \\
\hline Median (range) follow-up (manths) & \multicolumn{2}{|c|}{$24.3(0-41)$} & \multicolumn{2}{|c|}{$24.9(0-45)$} & 0.28 & \\
\hline Average (SD) ABPI at inclusion & \multicolumn{2}{|c|}{$0.64(0.18)$} & \multicolumn{2}{|c|}{$0.62(0.18)$} & 0.61 & \\
\hline Average (SD) $\mathrm{ABPl}$ at 12 months & \multirow{2}{*}{\multicolumn{2}{|c|}{$0.71(0.19)$}} & \multirow{2}{*}{\multicolumn{2}{|c|}{$0.70(0.22)$}} & 0.73 & \\
\hline Average (SD) change in $A B P l l$ in & & & & & & \\
\hline 12 months & \multicolumn{2}{|l|}{0.07} & \multicolumn{2}{|c|}{0.08} & 0.71 & \\
\hline
\end{tabular}

Mann-Whitney $U$ test for comparison of number of events or average follow-up period between groups, and ${ }^{b} \chi^{2}$-test for comparison of fraction of patients reaching events between groups. 


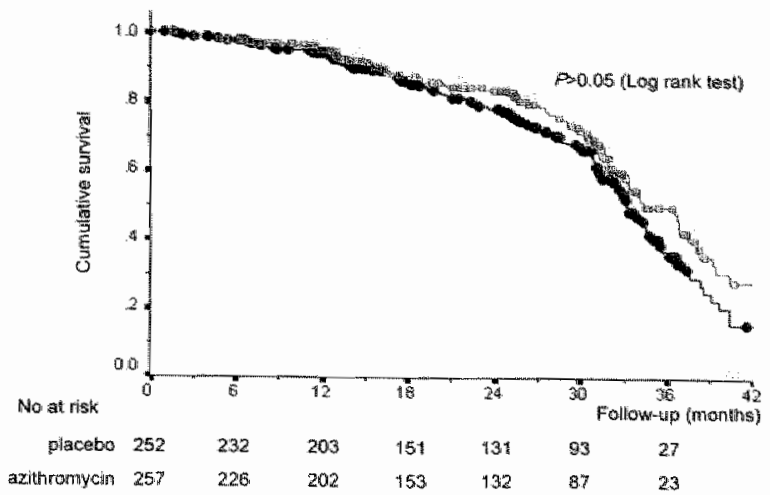

Figure 8.1 Cumulative freedom from the primary (combine) endpoint (death and/or any cardiovascular event) in the azithromycin (black curve) and placebo group (grey curve).

\subsection{2 $\mathrm{ABPl}$ and azithromycin}

The average (SD) $A B P I$ at inclusion was $0.63(0.18)$. This increased significantly to $0.70(0.21)$ in the total group after one year (Wilcoxon signed rank test, $P=0.001$ ). This increase in $A B P \|$ resulted mainly from interventions (PTA or surgery). For the patients who did not undergo any intervention within the first year, the ABPI increased slightly, though significantly from 0.66 to 0.68 (Wilcoxon signed rank test, $P=0.009$ ). Given the reproducibility of $A B P I$ measurements this difference may not reflect an actual clinical improvement. In contrast, the ABPI increased from $0.58(0.17)$ to $0.74(0.23)$ in those patients who had an intervention within one year after randomisation. This difference is both clinically and statistically significant (Wilcoxon signed rank test, $P=0.001$ ). Whether the patients had undergone an intervention or not, azithromycin did not affect (the change in) ABPI at one year (Mann-Whitney $U$ Test, $P=0.71$ ) (Table 8.5). The number of patients showing a significant increase or decrease in ABPI (by 0.1 point) did not differ significantly between azithromycin- and placebo-treated patients $\left(\chi^{2}\right.$-test, $\left.P=0.21\right)$. Exclusion of patients with critical limb ischemia (12\%) from the analyses did not alter any of the above associations.

\subsubsection{Chlamydia pneumoniae serology, extent of PAD and future events}

The mean Chlamydia pneumoniae IgA-titre and the prevalence of Chlamydia pneumoniae seropositivity ( $\lg \mathrm{A} \geq 16 \mathrm{EIUs})$ were comparable in the azithromycin and placebo group (Table 8.4). Chlamydia pneumoniae serology was not 
related to severity of peripheral arterial disease (Fontaine class or ABPI) at inclusion. However, patients who reached a cardiovascular (combined) endpoint (Mann-Whitney $U$ test, $P=0.02$ ), and especially a peripheral arterial endpoint (Mann-Whitney $U$ test, $P=0.01$ ) had a higher average $\lg A$ titre compared to patients who remained free of events (Table 8.6). Ch/amydia pneumoniae lgA seropositivity was related to the development of the combined endpoint $\left(\gamma^{2}\right.$-test, $\left.P=0.03\right)$, and of peripheral arterial events more specifically ( $\alpha^{2}$-test, $p=0.05$ ) (Table 8.6).

Despite the association between Chlamydia pheumoniae serology and the occurrence of events, azithromycin treatment did not reduce the risk of any event in the total patient group or in the subgroup of seropositive patietns.

Table 8.6 Prevalence of Chlamydia pneumoniae $\lg$ A seropositivity (lgA $>16$ EIUs) and average (SD) Chlamydia pneumoniae IgA titre in the patients in relation to cardiovascular endpoints.

\begin{tabular}{lcccc}
\hline & $\begin{array}{c}\% \\
\text { IgA seropositivity }\end{array}$ & $P^{\mathrm{a}}$ & $\begin{array}{c}\text { Average (SD) } \\
\text { UgA titre (ElUs) }\end{array}$ & $P^{\mathrm{b}}$ \\
\hline All patients $(\mathrm{N}=509)$ & 52 & & $28(30)$ & \\
Reaching Combined endpoint $(\mathrm{N}=182)$ & 59 & & $32(34)$ & \\
Free of combined endpoint $(\mathrm{N}=327)$ & 49 & 0.03 & $25(28)$ & 0.02 \\
Reaching Coronary event $(\mathrm{N}=33)$ & 50 & & $29(34)$ & \\
Free of coronary event $(\mathrm{N}=476)$ & 52 & 0.83 & $28(31)$ & 0.69 \\
Reaching Cerebral event $(\mathrm{N}=32)$ & 60 & & $27(27)$ & \\
Free of Cerebral event $(\mathrm{N}=477)$ & 51 & 0.36 & $28(31)$ & 0.49 \\
Reaching $P A D$ event $(\mathrm{N}=108)$ & 61 & & $36(37)$ & \\
Free of $\mathrm{PAD}$ event $(\mathrm{N}=401)$ & 49 & 0.05 & $25(28)$ & 0.01 \\
Death $(\mathrm{N}=45)$ & 59 & & $32(30)$ & \\
Free of death $(\mathrm{N}=464)$ & 51 & 0.34 & $27(31)$ & 0.26 \\
\hline
\end{tabular}

a $x^{2}$-lest: ${ }^{b}$ Mann-Whitney $U$ test.

\subsection{Discussion}

Our data shows that a short course of azithromycin does not reduce the risk of death or cardiovascular events in patients with lower limb ischemia secondary to occlusive peripheral atherosclerotic disease, irrespective of their serological status. Furthermore, azithromycin treatment did not affect the ABPI in these patients.

A number of randomised clinical trials assessing the effect of antibiotics on atherosclerosis related complications or biochemical and hemodynamic endpoints have been published (Table 8.7). Generally, in those studies reporting a benefit from antibiotics, a small number of patients have been 
included or followed for only a limited time, so that only a modest number of events has been observed under antibiotic exposure. Larger trials with longer follow-up periods have, in accordance with our data, unequivocally shown that antibiotics have no effect in reducing the risk for clinical cardiovascular endpoints. ${ }^{12-14,26}$ In total, including the present study, 12,901 patients have been included in the randomised clinical antibiotic trials with clinical cardiovascular endpoints (Table 8.7). The studies reporting beneficial effects of antibiotics on cardiovascular risk prevention have included 1583 patients, and 858 of these were randomised to receive the experimental treatment. ${ }^{11,27-30}$ In contrast, 11,318 patients were included and 5,660 patients were randomised to receive an antibiotic in the negative studies. ${ }^{12-14,26,31,32}$ In order to demonstrate the potentially beneficial effects of antibiotics on atherosclerosis using a limited number of patients (and cardiovascular events) "several authors have chosen to study surrogate endpoints that might be more sensitive to the antiatherogenic effects of antibiotics, such as carotid intima media thickness, ${ }^{31}$ basal NO production, ${ }^{33}$ flow-mediated dilatation, ${ }^{34,35}$ aortic expansion rate, ${ }^{36,37}$ matrix metalloproteinase metabolism, ${ }^{38}$ or presence of Chlamydia pneumoniae DNA in vascular tissue. ${ }^{39}$

Table 8.7 Overview of randomised clinical trials of antibiotics in cardiovascular disease.

\begin{tabular}{|c|c|c|c|c|c|c|c|c|}
\hline \multirow[t]{2}{*}{ Trial/Author } & \multirow[t]{2}{*}{ Diagnosis } & \multicolumn{2}{|c|}{ Treatment } & \multirow{2}{*}{ Follow-up } & \multicolumn{3}{|c|}{$N$} & \multirow[t]{2}{*}{ Result } \\
\hline & & $A B$ & Duration & & Total & $A B$ & $P L$ & \\
\hline Gupta et al & $C A D$ & azi & $3-6 d$ & $18 \mathrm{mo}$ & 60 & 40 & 20 & $\downarrow$ CVE \\
\hline ISAR-3 30 & stent & roxi & $4 w$ & $12 \mathrm{mo}$ & 1,010 & 506 & 504 & $\downarrow$ restenosis \\
\hline CLARIFY $Y^{29}$ & ACS & clari & $3 \mathrm{mo}$ & $18 \mathrm{mo}$ & 148 & 74 & 74 & $\downarrow$ CVE \\
\hline \multirow[t]{2}{*}{ STAMINA ${ }^{2 B}$} & ACS & $a z i$ & $3 d$ & $12 \mathrm{mo}$ & 325 & 111 & 107 & $\downarrow$ CVE \\
\hline & & amoxi & $1 w$ & & & 107 & & \\
\hline Wiesli etal ${ }^{2}$ & PAD & $r o \times i$ & $4 w$ & $20 \mathrm{mo}$ & 40 & 20 & 20 & $\downarrow P A D$ events \\
\hline $\mathrm{RO} \times \mathrm{IS}^{32}$ & $\mathrm{ACS}$ & roxi & $30 \mathrm{~d}$ & $6 \mathrm{mo}$ & 202 & 102 & 100 & $=\mathrm{CVE}$ \\
\hline ACADEMIC ${ }^{12}$ & CAD & azi & $3 \mathrm{mo}$ & $24 \mathrm{mo}$ & 302 & 150 & 152 & $=C V E$ \\
\hline ANTIBIO & ACS & roxi & $6 w$ & $12 \mathrm{mo}$ & 872 & 433 & 439 & $=\mathrm{CVE}$ \\
\hline WIZARD $^{1,3}$ & $\mathrm{CAD}$ & $a z i$ & $3 \mathrm{mo}$ & $24 \mathrm{mo}$ & 7,722 & 3866 & 3.856 & $=$ CVE \\
\hline AZACS ${ }^{2 B}$ & ACS & azi & $5 d$ & $24 \mathrm{mo}$ & 1.439 & 716 & 723 & $=\mathrm{CVE}$ \\
\hline Sander et al. & CVD & roxi & $4 w$ & $48 \mathrm{mo}$ & 272 & 136 & 136 & $=C \mathrm{VE}$ \\
\hline SPACE & PAD & $a z i$ & $3 d$ & $24 \mathrm{mo}$ & 509 & 257 & 252 & $=C V E$ \\
\hline \multirow{3}{*}{\multicolumn{5}{|c|}{$\begin{array}{l}N \text { of patients in positive clinical endpoint trials } \\
N \text { of patients in negative clinical endpoint trials } \\
N \text { of patients in all clinical endpoint trials }\end{array}$}} & 1,583 & 858 & 725 & \\
\hline & & & & & 11,318 & 5,660 & 5,658 & \\
\hline & & & & & 12,901 & 6,518 & 6,383 & \\
\hline
\end{tabular}

Ab: antibiatic; $A B$ : antibiotic group; ACS: acute coronary syndromes; amoxi: amoxicylin; azi: azithromycin; $\mathrm{CAD}$ : stable coronary artery disease; clari: clarithromycin; CVE: cardiovascular event; CVD: cerebrovascular disease; $d$ : days; mo: months; PAD: peripheral arterial disease; PL placebo group; roxi: roxithromycin; $w$; weeks. '=": no effect: " $\downarrow$ '; reduced.

The demonstration of (a lack of) beneficial effects in cardiovascular event reduction by the clinical trials does not necessarily (dis)prove the infectious 
concept of atherosclerosis. Accruing sero-epidemiological, histological, in vitro, and animal experimental data strongly suggest that infections play a (modulatory) role in atherogenesis in general ${ }^{40}$ and in the development of peripheral arterial disease in particular. ${ }^{41}$ In our study population, the baseline Chlamydia pneumoniae serology was not related to the extent of atherosclerotic disease in terms of clinical severity or ABPI at inclusion in the study. However, we observed an association between Chlamydia pneumoniae serology and development of future cardiovascular events and especially peripheral arterial events during follow-up. In spite of that, the 3-day azithromycin treatment did not result in a significant reduction of events in this population. In line with this findings, antibiotic treatment has proven to have no effect on Chlamydia pneumoniae titres in cardiovascular patients. ${ }^{28,31,32,36,42}$

The lack of beneficial effects from antibiotics in the prevention of atherosclerosis-related complications may be related to inadequate study medication and/or sub-optimal patient selection. We chose azithromycin as this was the most commonly used antibiotic in the trials with cardiovascular endpoints. Azithromycin has proven to be well tolerated and can be used safely in patients with atherosclerotic disease..$^{42}$ In vitro work suggested that vascular Chlamydia pneumoniae strains were susceptible to azithromycin as well as to roxithromycin and doxycyline. ${ }^{43}$ Instinctively one would expect that higher doses of antibiotics or longer treatment duration should have been more effective in reducing cardiovascular risk. Surprisingly, benefit from azithromycin treatment has been shown by studies with short course treatments (3-6 days, total azithromycin dose varying between 1500 and $3000 \mathrm{mg}){ }^{11,28}$ whereas trials with prolonged azithromycin treatment regimes did not show any beneficial effects. ${ }^{12,13}$ Irrespective of the duration of a single antibiotic course, published data suggest that if there is any effect, it may wear off with time. A preliminary report of the ROXIS trial showed a significant reduction of the primary endpoint (cardiac ischaemic death, myocardial infarction, and severe recurrent ischaemia) by roxithromycin at 31 days ${ }^{10}$ whereas this effect had worn off at 6 months. ${ }^{32}$ Similarly, roxithromycin seemed to reduce intima-media thickness progression in patients with cerebrovascular disease during the first two years after treatment, but this effect was lost after 4 years. ${ }^{31} \mathrm{~A}$ temporary effect of antibiotic treatment has also been suggested by the data of the WIZARD trial showing a reduced death or myocardial infarction risk at six months after randomisation but not after a longer follow-up. ${ }^{13}$ Bearing in mind that our study population was too small to observe a sufficient number of early events (i.e., within six months from randomisation), our data did not support an early effect of azithromycin on cardiovascular events that waned over time. Antibiotics may have only a transient effect, as patients may contract recurrent Chlamydia pneumoniae infections or suffer from Chlamydia pneumoniae reactivation, after the microbe has been forced into a latent state, instead of being eliminated by 
the antibiotic treatment. Indeed, in an in vitro continuous infection model of epithelial cells, prolonged azithromycin treatment reduced but did not completely eliminate Chlamydia pneumoniae.4 Furthermore, Chlamydia pneumoniae carried within circulating monocytes has shown to be refractory to standard anti-chlamydial treatments such as azithromycin. ${ }^{45}$ It remains to be seen whether longer-duration antibiotic treatments or repeated antibiotic treatment cycles would result in a significant cardiovascular risk reduction.

In addition to Chlamydia pneumoniae, several other pathogens have been implicated in atherogenesis such as Helicobacter pylori, ${ }^{46}$ cytomegalovirus, ${ }^{47}$ and herpes simplex virus. ${ }^{48}$ In fact, it seems that the total pathogen burden more than an individual micro-organism is associated with increased risk of developing cardiovascular disease. ${ }^{41,49}$ Thus, treatments aimed at Chlamydia pneumoniae may not cover all contributory pathogens, explaining the failure of current antibiotic regimes.

A critical issue of the randomised clinical trials is the selection of patients. Several authors have chosen to include only Chlamydia pneumoniae seropositive patients. ${ }^{11-13,27}$ High Chlamydia pneumoniae antibody titres have been associated with presence of atherosclerosis and the development of cardiovascular events. However, antibiotics do not seem to affect Chlamydia pneumoniae titres. ${ }^{28,31,32,36,42}$ This matter is further complicated by the fact that no uniform criteria for Chlamydia pneumoniae seropositivity have been formulated. ${ }^{22}$ Therefore, since the prevalence of Chlamydia pneumoniae antibodies in the general population is high, we chose to include patients regardless of their serological status. ${ }^{50}$

Atherosclerotic disease status at entry may be important for the outcome of antibiotic intervention trials. Experimental data suggests that Chlamydia pneumoniae may promote all stages of atherosclerosis development, i.e., plaque growth, rupture, thrombosis and neointimal formation after vascular intervention. ${ }^{51}$ In previously published trials, patients with acute coronary syndromes (i.e., acute myocardial infarction, unstable angina or non q wave infarcts), stable atherosclerotic disease of the coronary, cerebral and peripheral arteries, or after coronary stent placement have been included, and treated with variable success with antibiotics (see Table 8.7). Only neointimal formation after stent-placement seems to be inhibited by roxithromycin, but this result has come from only one study and needs to be verified by others. We attempted to assess the influence of antibiotics on the progression of atherosclerosis in patients with PAD. To avoid the influence of tissue destruction following acute vascular events or surgery on inflammatory responses affecting atherosclerosis we included only patients with stable PAD free from recent events and interventions.

In summary, this is currently the largest study assessing the effect of azithromycin on patients with peripheral arterial disease. Although Chlamydia 
154 chuter

pneumoniae serology was related to the development of cardiovascular events, the 3-day azithromycin treatment did not reduce the prevalence of cardiovascular complications, and has therefore no place in the secondary prevention of patients with stable peripheral arterial disease. 


\subsection{References}

1. Ross R. Atherosclerosis-an inflammatory disease. N Engl J Med. 1999;340:115-26.

2. Ophuls W. Arteriosclerosis and cardiovascular disease: their relation to infectious diseases. JAMA. 1921:76:700-1.

3. Frothingham $\mathrm{C}$. The relationship between acute infectious diseases and arterial lesions. Arch Intem Med. 1911;8:153-62.

4. Osler W. Diseases of the arteries. In: Osler W, ed. Modern Medicine: /ts Practice and Theory. Philadelphia: Lea and Febiger; 1908:429-47.

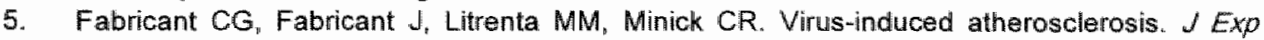
Med. 1978;148:335-40.

6. Spodick DH, Flessas AP, Johnson MM. Association of acute respiratory symptoms with onset of acute myociardial infarction: prospective investigation of 150 consecutive patients and matched control patients. Am J Cardiol. 1984;53:481-2.

7. Pesonen $E_{n}$ Sitonen $O$. Acute myocardial infarction precipitated by infectious disease. Am Heart J. 1981;101:512-3.

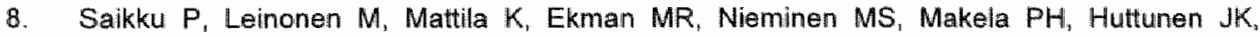
Valtonen $V$. Serological evidence of an association of a novel Chlamydia, TWAR, with chronic coronary heart disease and acute myocardial infarction. Lancet. 1988;2:983-6.

9. Kuo CC, Shor A, Campbell LA, Fukushi $H_{*}$ Patton DL, Grayston JT. Demonstration of Chlamydia pneumoniae in atherosclerotic lesions of coronary arteries. I Infect Dis. 1993;167:841-9.

10. Gurfinkel $E$, Bozovich $G$, Daroca $A, B e c k E$, Mautner $B$. Randomised trial of roxithromycin in non-Q-wave coronary syndromes: ROXIS Pilot Study. ROXIS Study Group. Lancet. 1997;350:404-7.

11. Gupta S, Leatham EW, Carrington D, Mendall MA, Kaski JC, Camm AJ. Elevated Chiamydia pneumoniae antibodies, cardiovascular events, and azithromycin in malle survivors of myocardial infarction. Circulation. 1997;96:404-7.

12. Muhllestein JB, Anderson JL, Carlquist JF, Salunkhe $K$, Horne BD, Pearson RR, Bunch TJ, Allen $A$, Trehan $S$, Nielson $C$. Randomized secondary prevention trial of azithromycin in patients with coronary artery disease: primary clinical results of the ACADEMIC study. Circulation. 2000;102:1755-60.

13. O'Connor CM, Dunne MW, Pfeffer MA, Muhlestein JB, Yao L, Gupta S, Benner RJ, Fisher $M R$, Cook TD. Azithromycin for the secondary prevention of coronary heart disease events: the WIZARD study: a randomized controlled trial. Jama. 2003;290:1459-66.

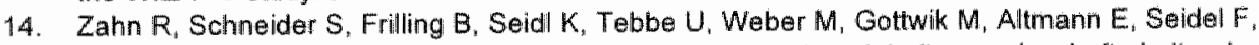
Rox J. Hoffler $U$, Neuhaus $K-L$. Senges $J$, for the Arbeitsgemeinschaft Leitender Kardiologischer Krankenhausarzte (Working Group of Leading Mospital Cardialogists; ALKK). Antibiotic Therapy After Acute Myocardial Infarction: A Prospective Randomized Study. Circulation. 2003;107:1253-9.

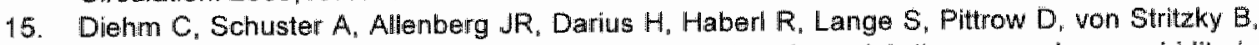
Tepohll G. Trampisch HJ. High prevalence of peripheral arterial disease and co-morbidity in 6880 primary care patients: cross-sectional study. Atherosclerosis. 2004:172:95-105.

16. Meyer AP, Bril-Bazuin C, Mattie H, van den Broek P.J. Uptake of azithromycin by human monocytes and enhanced intracellular antibacterial activity against Staphylococcus aureus. Antimicrob Agents Chemother. 1993;37:2318-22.

17. Dunn CJ, Barradell LB. Azithromycin. A review of its pharmacological properties and use as 3-day therapy in respiratory tract infections. Orugs. 1996;51:483-505.

18. World Medical Association Declaration of Helsinki. Recommendations guiding physicians in biomedical research involving human subjects. Cardiovasc Res. 1997;35:2-3.

19. Dormandy JA, Murray GD. The fate of the clatudicant - A prospective study of 1969 claudicants. Eur a/ Vasc Surg. 1991:5:131-3.

20. Gottliep SS. Dead is dead--artificial definitions are no substitute. Lancet 1997,349:662-3. 
21. Vainas $T$, de Graaf $R$, Stassen FR, Kurvers HA, Grauls GE, Kitslaar PJ, Bruggeman CA. Chlamydia phoumoniae serology: comparing a commercial enzyme immunoassay and microimmunofluorescence test in patients with cardiovascular disease. APMIS. $2003: 111: 363-9$.

22. Dowell SF, Peeling RW, Boman J, Carlone GM, Fields BS, Guarner J, Hammerschlag MR, Jackson LA, Kuo CC, Maass M, Messmer TO, Talkington DF, Tondella ML, Zaki SR. Standardizing Chlamydia pneumoniae assays: recommendations from the Centers for Disease Control and Prevention (USA) and the Laboratory Centre for Disease Controll (Canada). Clin Infect Dis. 2001;33:492-503.

23. Vainas $T$, Kurvers $H A_{*}$ Mess $W H$, de Graaf $R$, Ezzahiri $R_{*}$ Tordoir JH, Schurink $G W$, Bruggeman CA, Kitslaar PJ. Chlamydia pneumoniae serology is associated with thrombosisrelated but not with plaque-related microembolization during carotid endarterectomy. Stroke. $2002 ; 33: 1249-54$.

24. Sander D, Winbeck $K$, Klingelhofer J, Etgen $T$, Conrad $B$. Enhanced progression of early carotid atherosclerosis is related to Chlamyolia pneumoniae (Taiwan acute respiratory) seropositivity. Circulation. 2001;103:1390-5.

25. Markus $H S$, Sitzer $M$, Carrington $D$, Mendall MA, Steinmetz $H$. Chlamydia pneumoniae infection and early asymptomatic carotid atherosclerosis. Circulation. 1999;100:832-7.

26. Cercek B, Shah PK, Noc M, Zahger D, Zeymer U, Matetzky S, Maurer $G$, Mahrer $P$. Effect of short-term treatment with azithromycin on recurrent ischaemic events in patients with acute coronary syndrome in the Azithromycin in Acute Coronary Syndrome (AZACS) trial: a randomised controlled trial: Lancet. 2003;361:809 13 .

27. Wiesli $P$, Czenwenka $W$, Meniconi A, Maly FE, Hoffmann U, Vetter $W$, Schulthess $G$. Roxithromycin treatment prevents progression of peripheral arterial occlusive disease in Chlamydia pneumoniae seropositive men: a randomized, double-blind, placebo-controlled trial. Circulation. 2002;105:2646-52.

28. Stone AF, Mendall MA, Kaski JC, Edger TM, Risley P, Poloniecki J, Camm AJ, Northfield TC. Effect of treatment for Chlamydia pneumoniae and Helicobacter pylori on markers of inflammation and cardiac events in patients with acute coronary syndromes: South Thames Trial of Antibiotics in Myocardial Infarction and Unstable Angina (STAMINA). Circulation. 2002;106:1219-23.

29. Sinisalo $\mathrm{J}$, Mattila $\mathrm{K}$, Vaitonen $\mathrm{V}$, Anttonen $\mathrm{O}$, Juwonen $\mathrm{J}$, Melin $\mathrm{J}$, Vuorinen-Markkola $\mathrm{H}_{2}$ Nieminen MS. Effect of 3 months of antimicrobial treatment with clarithramycin in acute nonq-wave coronary syndrome. Circulation. 2002;105:1555-60.

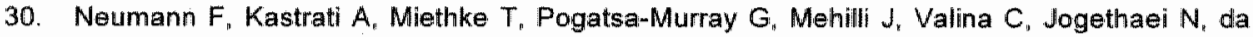
Costa CP. Wagner' $H$, Schomig A. Treatment of Chlamydia pnetumoniae infection with roxithromycin and effect on neointima proliferation after coronary stent placement (ISAR-3): a randomised, double-blind, placebo-controlled trial. Lancet. 2001;357:2085-9.

31. Sander $D$. Winbeck $K$, Klingehhofer $J$, Etgen $T$ "Conrad B. Progression of early caratid atherosclerosis is only temporarily reduced after antibiotic treatment of Chtamydia pneumoniae seropositivity. Circulation. 2004;109:1010-5.

32. Gurfinkel $E$, Bozovich $G$, Beck E, Testa E, Liwellara B, Mautner B. Treatment with the antibiotic roxithromycin in patients with acuite non- Q-wave coronary syndromes. The final report of the ROXIS Study. Eur Heart J. 1999;20:121-7.

33. Sinisalo J, Mattila $K_{i}$ Nieminen MS, Valtonen V. Syrjala M, Sundberg S, Saikku P. The effect of prolonged doxycycline therapy on Chlamydia pneumoniae serological markers, coronary theart disease risk factors and forearm basal nitric oxide production. $J$ Antimicrob Chemother. $1998: 41: 85-92$.

34. Kuvin JT, Gokce N, Holbrook M, Hunter LM, Patel AR, Sliney KA, Craven DE, Grayston JT, Keaney JF. Jr., Karas RH, Vita JA. Effect of short-term antibiotic treatment on Chlamydia pneumoniae and peripheral endothelial function. Am I Cardiol. 2003;91:732-5.

35. Parchure $N$, Zouridakis EG, Kaski JC. Effect of azithromycin treatment on endothelial function in patients with coronary artery disease and evidence of Chlamydia preumoniae infection. Girculation. 2002; 105:1298-303. 
36. Mosorin M, Juvonen J, Biancari $F$, Satta J, Surcel HM, Leinomen M, Saikkul $P$, Juvonen $T$. Use of doxycycline to decrease the growth rate of abdominal aortic aneurysms: $A$ randomized, double-blind, placebo-controlled pilot study. I Vasc Surg. 2001:34:606-10.

37. Vammen $S$, Lindholt JS, Ostergaard $L$, Fasting $H$, Henneberg EW. Randomized double-blind controlled trial of roxithromycin for prevention of abdominal aortic aneurysm expansion. $B r J$ Surg. 2001;88:1066-72.

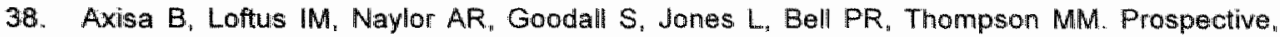
randomized, double-blind trial investigating the effect of doxycycline on matrix metalloproteinase expression within atherosclerotic carotid plaques. Stroke $2002 ; 33$ : 2858-64.

39. Melissano G, Blasi F, Esposito G, Tarsia P, Dordoni L. Arosio C, Tshomba $Y$, Fagetti L, Allegra L, Chiesa R. Ch/amydia pneumoniae eradication from carotid plaques. Results of an apen, randomised treatment study. Eur J Vasc Endovasc Surg. 1999;18:355-9.

40. Leinonen $M$, Saikku P. Evidence for infectious agents in cardiovascular disease and atherosclerosis. Lancet infect Dis. 2002;2:11-7

41. Bloemenkamp DG, Mali WP, Tanis BC, Rosendaal FR, van den Bosch MA, Kemmeren JM, Algra $A$, Ossewaarde JM, Visseren $F L$, van Loon $A M$, van der Graaf $Y$. Chiamydia pneumoniae. Helicobacter pylori and cytomegalovirus infections and the risk of peripheral arterial disease in young women. Atherosclerasis. 2002;163:149-56.

42. Jackson LA, Stewart DK, Wang SP, Cooke DB, Cantrell T, Grayston JT. Safety and effect on anti-Chlamydia pneumoniae antibody titres of a 1 month course of daily azithromycin in adults with coronary artery disease [in Process Citation]. J Antimicrob Chenother. 1999;44:411-4.

43. Gieffers J, Solbach W, Maass M. In Vitro Susceptibilities of Chlamydia pneumoniae Strains Recovered from Atherosclerotic Coronary Arteries. Antimicrab Agents Chemother. 1998:42:2762-64.

44. Kutlin A, Roblin PM, Hammerschlag MR. Effect of Prolonged Treatment with Azithromycin. Clarithromycin, or Levofloxacin on Chlamydia pneumoniae in a Continuous-lnfection Model. Antimicrob Agents Chemother. 2002;46:409-12.

45. Gieffers J, Fullgraf $H_{3}$ Jahn $J$, Klinger $M$, Dalhoff $K$, Katus $H A$, Solbach $W$, Maass $M$. Chlamydia pneumoniae infection in circulating human monocytes is refractory to antibiotic treatment. Circulation. 2001;103:351-6.

46. Aceti A, Mazzacurati G, Amendolea M, Pennica A, Zechini B, Trappolini M, Puletti M. Relation of $C$ reactive protein to cardiovascular risk factors. H pylori and $C$ pneumoniae infections may account for most acute coronary syndromes. BMJ. 1996;313:428-9.

47. Adam E, Melnick JL, Probtsfield JL, Petrie BL, Burek J. Bailey KR, McCollum CH, DeBakey ME. High levels of cytomegalovirus antibody in patients requiring vascular surgery for atherosclerosis. Lancet. 1987;2:291-3.

48. Siscovick DS, Schwartz SM, Corey L, Grayston JT, Ashley R, Wang SP, Psaty BM, Tracy RP. Kuller LH, Kronmal RA. Chlamydia pneumoniae, herpes simplex virus type 1 , and cytomegalovirus and incident myocardial infarction and coronary heart disease death in older adults: the cardiovascular health study. Circulation. 2000;102:2335-40.

49. Espinola-Klein C, Rupprecht HJ, Blankenberg S, Bickel C, Kopp H, Rippin G, Victor A, Hafner $G$, Schlumberger W, Meyer J. Impact of infectious burden on extent and long-term prognosis of atherosclerosis. Circulation 2002;105:15-21.

50. Grayston JT. Background and current knowledge of Chramydia pneumoniae and atherosclerosis. II Infect Dis. 2000;181 $\mathrm{S3}: \$ 402-10$.

51. Libby P. Egan D, Skarlatos S. Roles of infectious agents in atherosclerosis and restenosis: an assessment of the evidence and need for future research. Circulation. 1997;96:4095-103. 


\section{Section 6}

\section{General discussion and Summary}

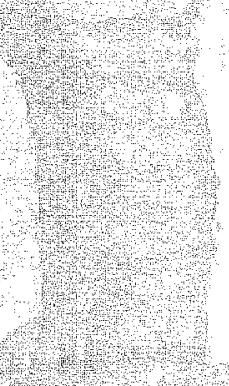




\section{Chapter}

\section{General discussion}

Parts of this chapter has been published as

Vainas $T$, Stassen FR, Schurink GW, Tordoir JH, Welten RJ, van den Akker LH, Kurvers HA, Bruggeman CA, Kitslaar PJ. Reply to: Effect of Macrolides on Peripheral Arterial Disease Depends on Patient Selection and Adequate

Treatment. P.A. Krayenbuehl, P. Wiesli, T. Meier, G. Schuithess. Eur J Vasc Endovasc Surg. 2005;30:337.

Vainas $T$ and Sayed $S$. Antibiotics in acute and chronic coronary syndromes. Klinik und Forschung. 2005;11:4-7. 


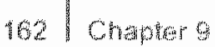


The data presented in this thesis conforms to the notion that atherosclerosis is an inflammatory process. It confirms and strengthens the relationship between C-reactive protein and Chlamydia pneumoniae infection on the one hand and atherosclerotic disease on the other, and offers moreover some novel insights in this relationship.

\subsection{CRP \& atherosclerosis}

\section{9. a Serum hSCRP as marker of cardiovascular risk and of extent of atheroscferotic disease.}

The pentraxin CRP has consistently been associated with (coronary) atherosclerotic disease. It has been shown that patients with coronary artery disease $^{1-7}$ and cerebrovascular disease ${ }^{8,9}$ have elevated levels of serum CRP, measured highly sensitively ( $h S C R P$ ). Additionally, $h s C R P$ has been identified as an independent marker of cardiovascular risk in patients with coronary artery disease ${ }^{10-21}$ or peripheral arterial disease ${ }^{22}$ and most intriguingly, in apparently healthy middle aged and elderly individuals. ${ }^{23-37}$ Regarding patients with PAD, it has been shown that hsCRP is inversely related to ankle-brachial pressure index ${ }_{138}$ walking performance ${ }^{39}$ and endothellal function. ${ }^{40}$ Studies assessing serum hsCRP in patients with abdominal aortic aneurysms were not available. We analysed the serum $h s C R P$ profile in patients with PAD (chapter 2) and in patients with asymptomatic abdominal aortic aneurysms (chapter 3 ). In both patient groups, the average serum hsCRP was in the range conferring increased risk for future cardiovascular events. Intriguingly, serum hsCRP was related to the extent of both diseases. Serum hsCRP showed a direct relationship with the diameter of the aneurysm in patients with AAA and an inverse relationship with ankle-brachial pressure index (as a marker of extent of peripheral arterial disease) in PAD patients. Following the latter patients prospectively we were able to establish an association between baseline hsCRP level and future cardiovascular events.

Considering the available literature and our data, it may be concluded that serum hsCRP is elevated in patients with any of the clinical manifestations of atherosclerosis (i.e., coronary artery disease, cerebrovascular disease, peripheral arterial disease and abdominal aortic aneurysms), that it is related to the extent of any type of atherosclerotic vascular disease and that it is an important predictor of cardiovascular risk in healthy individuals as well as in patients with any type of atherosclerotic vascular disease, adding prognostic value to conventional risk estimation models. ${ }^{41}$ 


\subsection{Pro-atherogento properties and vascular production of CRP}

The consistent association between serum hsCRP and extent and progression of atherosclerotic disease has led to the question whether CRP is merely a marker of atherosclerosis or an actual partaker in the development of the disease. As discussed in chapter 1, many in vitro studies have shown that CRP has pro-atherogenic properties on all cell types involved in the development of atherosclerosis, i.e., endothelial cells, smooth muscle cells and macrophages. Most of these in witro effects have been demonstrated by using CRP concentrations ranging from 5 to $900 \mathrm{mg} / \mathrm{l}$, which is far above the serum concentration of CRP used to denote high risk for future events $(3 \mathrm{mg} / \mathrm{l})$. It has therefore been questioned whether CRP is able to elicit these effects in the vascular wall. ${ }^{42}$ Accumulation in the vessel wall by uptake of serum CRP, may yield high local CRP concentrations, overcoming the discrepancy between the 'low' serum CRP concentration and the amounts needed for CRP to exert its pro-atherogenic in situ properties. Alternatively, local production of CRP by cells of the vessel wall may support local paracrine loops and thus mediate the potential in situ pro-atherogenic effects of CRP that has been observed in the in vitro studies. Ample evidence for the extra-hepatic praduction of CRP has been gathered suggesting that a variety of cells and tissues produce CRP in response to stress as part of a localized immunological reaction. It has been shown that neuronal cells, ${ }^{43}$ alveolar macrophages, ${ }^{44}$ epithelial cells, ${ }^{45}$ cardiomyocytes, ${ }^{45}$ lymphocytes ${ }^{47.48}$, and monocytes ${ }^{49}$ produce CRP. Production of CRP has been demonstrated in coronary atherosclerotic plaques and venous coronary artery bypass grafts, probably by macrophages and smooth muscle cells. ${ }^{50,51}$ In section 2 we demonstrated that femoral atherosclerotic plaques (chapter 2) and abdominal aortic aneurysms (chapter 3) are also capable of CRP production suggesting that vascular CRP production is a generalized phenomenon in the diseased arteries. This notion is supported by two recent studies showing that human vascular smooth muscle cells ${ }^{52}$ and endothelial cells ${ }^{53}$ produce CRP when stimulated with $\mathrm{LL}-6$ and $\| L-1$. Intriguingly, LPS was also able to stimulate vascular smooth muscle cells to produce CRP ${ }^{52}$ offering, in theory, a biological substrate for an interaction between infections and CRP as novel risk factors for atherosclerotic disease.

\subsection{Infection and atherosclerosis}

Following Saikku and colleagues, who first described an association between Chlamydia pneumoniae antibodies and coronary artery disease, a large number of sero-epidemiological studies exploring the relation between Chlamydia pneumoniae serology and atherosclerotic disease has been published, with conflicting results. This may be related to the fact that various 
serological assays and different criteria for the serological detection of chronic active or persistent Chlamydia pneumoniae infection have been used. ${ }^{54}$

The microimmunofluorescence test (MIF) has traditionally been used for the detection of Chlamydia pneumoniae antibodies. It is considered a sensitive and specific technique for the detection of acute chlamydia pneumoniae infections ${ }^{55}$ and is regarded as the gold standard for the detection of Chlamydia pneumoniae antibodies. ${ }^{56}$ However, the MIF test has considerable limitations. It is a semi-quantitative assay, not suited for automated sample processing which would be desired for screening purposes. Furthermore "it is labour intensive and time consuming, has a subjective outcome measure and is, therefore, poorly reproducible ${ }^{57}$ In chapter 4 , a commercially available enzyme immunoassay (EIA), a technically less demanding test with an objective endpoint, suited for high throughput and automated sample processing, was compared to the MIF. Our data showed that in patients with cardiovascular disease, the EIA yielded results comparable to the MIF, when measures were taken to obtain results in the linear portion of the detection curve by retesting sera with high titres at a higher predilution. Additionally, in our hands the EIA showed a better reproducibility than the MIF. Considering the practical advantages of EIA and the limited microbiological background and experience of cardiovascular investigators involved in Chlamydia pneumoniae related cardiovascular research, the use of EIA instead of MIF is recommended, in order to improve the external validity of these studies.

Despite the large numbers of sero-epidemiological trials assessing the association between chlamydia pneumoniae and atherosclerosis, no consensus regarding the serological detection of clinically relevant (vascular) Chlamydia pneumoniae infection has been reached. ${ }^{58}$ In chapter 5 we explored the correlation between Chlamydia pneumoniae antibodies and presence of Chlamydia pneumoniae DNA and/or proteins in atherosclerotic vascular tissue, in order to determine serological criteria for vascular Chlamydia pneumoniae infection. Our results indicated that, both, Chlamydia pheumoniae IgA and IgG-antibodies were poorly associated with the presence of Chlamydia pneumoniae antigens or DNA in the atherosclerotic vessel wall. This suggests that serum antibody titre measurement may be inadequate to detect patients with Chlamydia pneumoniae infested atherosclerotic plaques. On the other hand, although Chlamydia pneumoniae traces are generally found in atherosclerotic sites and not in healthy vascular tissue, our data presented in chapter 5, have shown, in accordance with other studies, that the presence of Chlamydia pneumoniae DNA or proteins was not related to plaque histology. This casts doubts on the theory that infestation of the vascular wall with chlamydia pneumoniae may stimulate advanced atherosclerotic lesion progression through in situ processes. 
The association between Chlamydia pneumoniae antibody titres and clinical signs of atherosclerotic disease has been explored in numerous cross sectional and longitudinal sero-epidemiologicall studies. 59 Although a few failed to verify the association between infection and atherosclerosis, the majority of these studies supported an association between Chlamydia pneumoniae serolagy and clinical manifestations of atherosclerotic disease. A recent meta-analysis. involving studies published between January 1997 and December 2000 , showed that a positive Chlamydia pneumoniae titre is related to atherosclerosis with a pooled odds ratio of 1.6 (95\% confidence interval Cl:1.3-2.0) ${ }^{60}$ This meta-analysis suggested that study design (cross-sectional versus nested case control studies) was a source of variability, as the association between infection and atherosclerosis was stronger in cross sectional studies. Additionally, this meta-analysis suggested that the duration of follow-up in the prospective studies was inversely related to the strength of this association. Data from our randomised clinical trial (chapter 8) supported a relation between baseline Chlamydia pneumoniae serology and future cardiovascular events among patients with peripheral arterial disease.

The fact that Chlamydia pneumoniae serology is associated with clinical manifestations of atherosclerotic disease whereas any sign of infection, whether serologic (antibodies) 61,62 or histologic (vascular presence of DNA/proteins), ${ }^{63,64}$ does not seem to be related to atherosclerotic plaque histology may suggest that in humans, Chlamydia pneumoniae does not stimulate advanced atherosclerotic lesion progression via the in situ processes that have been described in chapter 1 . In contrast, the association between infection and atherosclerosis might be mediated through the systemic effects of (non)vascular Chlamydia pneumoniae infection and/or by the host response to chlamydia pneumoniae infection. We have shown in this respect that Chlamydia pneumoniae serology is associated with hypercoagulability but not with histological plaque instability in patients with carotid artery disease (chapter 6). This conforms with the finding that, in patients with Chlamydia pneumoniae infections, plasma fibrinogen levels are elevated ${ }^{65}$ and that these levels decrease upon anti-microbial treatment. ${ }^{65}$ Chlamydia pneumoniae infection might also contribute to the development of atherosclerosis through stimulation of cytokine production, ${ }^{57}$ through interference with lipid metabolism $^{68,69}$ and by increased gelatinolytic activity. Furthermore, it has been shown that antibodies elicited against chlamydial HSP60 cross-react with human autologous HSP60 and can cause lysis of stressed endothelial cells that express human HSP60 on their surface. ${ }^{70}$ In other words, although in vitro studies have suggested that infection of vascular cells with Chlamydia pneumoniae is associated with atherosclerosis progression, in humans Chamydia oneumoniae may have clinically significant pro-atherogenic effects through systemic rather than in situ phenomena. 
Although Chlamydia pneumoniae has been studied most extensively in relation to atherosclerosis, a large number of viruses and other bacteria have been related to atherosclerosis development (see chapter 1.8). In fact, recent evidence suggests that total pathogen burden rather than exposure to individual micro-organisms is related to cardiovascular events. ${ }^{71.73}$ These data suggest that the interaction between individuals and the microbiological environment is more complex than traditionally anticipated. In most cases of acute infections, the link between a certain micro-organism and the disease is obvious, mostly fulfilling Koch"s postulates. However, in the case of chronic degenerative diseases such as atherosclerosis, rheumatoid arthritis, inflammatory bowel disease or chronic obstructive pulmonary disease, microorganisms may interact in many, not necessarily specific ways with the host (e.g.. direct effects on infected cells, induction of auto-immune reactions, stimulation of chronic inflammatory responses), making it difficult to prove a causal or at least modulatory involvement of the micro-organisms in disease initiation or progression.

\subsection{Interaction of inflammation and infectious organisms in the development of atherosclerosis}

Since CRP and Chlamydia pneumoniae - and in fact total pathogen burdenhas been related to atherosclerotic disease progression, it is plausible that (Ch/amydia pneumoniae) infections may interact with CRP in the stimulation of atherosclerosis progression. Data from the Helsinki Health Study has shown that persistently elevated antibodies against Chlamydia pneumoniae and elevated serum CRP had a synergistic effect on coronary risk. ${ }^{74}$ In fact, chronic active or persistent infections may give rise to chronically elevated serum CRP concentrations through maintenance of a sustained inflammatory response. In addition, the fact that Chlamydia pneumoniae is present in atherosclerotic plaques and that CRP is produced in atheroscierotic arteries may suggest that infestation of the vascular cells with Chlamydia pneumoniae (or other microorganisms) may stimulate vascular CRP production. In vitro experiments have shown that incubation of human smooth muscle cells with bacterial endatoxin stimulated CRP production. ${ }^{52}$ Although in our prospective trial, both, baseline serum hsCRP (chapter 2) and baseline Chlamydia pneumoniae serology (chapter 8) were related to future events, serum hsCRP concentration and Chlamydia pneumoniae serology were not correlated. As we had chosen to include patients with no clinical signs of respiratory tract infection in our trial, total pathogen burden rather than infection with Chlamydia pneumoniae should more likely be related to active inflammatory response and serum hsCRP concentration. 


\subsection{The role of host factors on the promatherogenic properties of inflammation and infection}

Taking into account the high incidence of Chlamydia pneumoniae antibodies in the general population, it seems likely that genetic factors may affect individual susceptibility for the pro-atherogenic effects of infections and, thus, determine the outcome and severity of chronic degenerative inflammatory diseases. Toll Like Receptor 4 (TLR4) and CD14 are among the genes involved in the regulation of immune responses, showing genetic variations with potential functional implications. The recently described human TLR4 polymorphism, $T L R 4+896 A>G$, has been associated with hyporesponsiveness to LPS $^{75}$ and seems to confer protection against the development of ultrasound detected carotid artery disease ${ }^{76}$ and acute coronary syndromes. ${ }^{77}$ Among pravastatine users this polymorphism has significantly been associated with a lower cardiovascular risk. ${ }^{78}$ A functional polymorphism in the promotor region of $C D 14$ at position -260 , the $C D 14(-260) C>T$ polymorphism, that enhances the transcriptional activity of the CD14 gene, has been associated with carotid artery intima media thickness, ${ }^{79}$ and increased risk of stroke ${ }^{B 0}$ or acute myocardial infarction. ${ }^{81,82}$ In contrast, several authors demonstrated a lack of association between this polymorphism and coronary artery or cerebrovascular

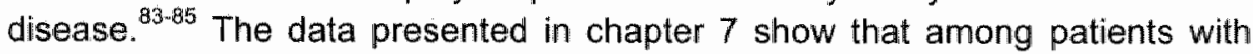
peripheral arterial disease the carrier trait TLR4 G-allele \& CD14 TT-genotype, rather than individual polymorphisms, is associated with extent of atherosclerotic disease. Considering the complexity of the innate immune system and its high degree of genetic variation, a significant number of collateral pathways may exist for innate immune responses, which differ in their cofactor requirements and their pattern recognition specificities. Ideally, all pathways should be taken into consideration and carrier traits instead of individual single nucleotide polymorphisms should be regarded when studying genetic predisposition of the innate immune system in relation to atheroscierosis or other multifactorial and polygenic inflammatory diseases. Our data illustrate the significance of taking a wider approach analyzing relevant carrier traits instead of individual polymorphisms in relation to atherosclerosis, and provide an explanation for inter-individual differences in susceptibility to atherosclerosis based on genetic variability of a combination of genes involved in innate immune regulation.

\subsection{Interventions based on the inflammatory and infectious aspects of atherosclerosis}

The novel insights into the pathogenesis of atherosclerosis offer new potential targets for (prophylactic) treatment of patients with atherosclerotic (cardio)vascular disease. 


\section{Ro Ro of anti-inlammatory drugs in atherosclerotric disease}

In view of the potent pro-atherogenic properties of CRP described in chapter 1.7, the strong association between serum hsCRP and cardiovascular disease and the active production of CRP in the atherosclerotic vessel wall may imply that CRP is not merely a biomarker of atherosclerotic disease but an actual partaker in atheroscierotic lesion development. Although anti-CRP treatment strategies as such have not been described yet, clinical evidence suggest that the potent protective effects of aspirin and statins may be related to lowering serum CRP. ${ }^{24,86,87}$ This is in accordance with recent data of Ridker et al. showing that when statin treatment resulted in low serum CRP levels it was associated with significant improvement of event free survival in patients with acute coronary syndromes irrespective of (LDL)cholesterol levels, suggesting that strategies designed to reduce inflammation may improve cardiovascular outcome. $^{88}$

\section{5.b The role of antibiotics in the treatment of atherosclerotic disease}

The sero-epidemiological and experimental data suggesting a possible association between Chlamydia pneumoniae infection and atherosclerosis triggered the interest of (cardio)vascular clinicians for the role of anti-chlamydial antibiotics as a new treatment modality for patients with atherosclerotic vascular disease. Indeed, two early small randomised clinical trials suggested that antibiotics may reduce cardiovascular risk in patients with coronary artery disease. $^{89,90}$ Prompted by these results, several investigators have tried to evaluate the effect of antibiotics on cardiovascular risk by observational casecontrol studies. A number of these studies demonstrated a survival benefit from exposure to anti-chlamydial antibiotics, ${ }^{91-94}$ although others refuted it. ${ }^{95-39}$ Considering the methodological shortcomings of these retrospective studies, randomised clinical trials were needed to determine the effectiveness of antibiotics in atherosclerotic disease prevention. Following the two initial positive pilot studies ${ }^{89.90}$ a number of randomised clinical trials have been designed and carried out worldwide with contradictory results. ${ }^{100-120}$ In general, favourable results were shown in studies with small sample size and/or limited follow-up, ${ }^{89,90,107,108,121}$ trials that have included patients with abdominal aortic aneurysms ${ }^{105,106}$ or studied surrogate endpoints such as carotid intima media thickness, ${ }^{121}$ basal NO production, ${ }^{100}$ flow mediated dilatation, ${ }^{110.115}$ aortic expansion rate ${ }^{105,106}$ and matrix metalloproteinase metabolism. ${ }^{111}$ In chapter 8 the results of our randomised clinical trial are presented, showing that a short term antibiotic prophylactic treatment did not offer any benefits in terms of clinical events or (changes in) ankle-brachial pressure index in patients with peripheral arterial disease. Similarly, recently published results of larger studies, involving patients with coronary artery disease, ${ }^{112-114,119.120}$ demon- 
strated no beneficial effect of antibiotics in the prevention of cardiovascular events or death.

Table 9.1 lists all the randomised clinical trials carried out to assess the effects of antibiotics on cardiovascular endpoints in patients with atherosclerotic disease of the coronary, cerebral and/or peripheral circulation.

Table 9.1 Overview of randomised clinical trials assessing the effect of antibiotics on cardiovascular events, in patients with atherosclerotic disease.

\begin{tabular}{|c|c|c|c|c|c|c|c|c|}
\hline \multirow[t]{2}{*}{ Trial/Author } & \multirow[t]{2}{*}{ Diagnosis } & \multicolumn{2}{|c|}{ Ttreatment } & \multirow{2}{*}{ Follow-up } & \multicolumn{3}{|c|}{$\mathrm{N}$} & \multirow[t]{2}{*}{ Result } \\
\hline & & $\mathrm{Ab}$ & Duration & & Total & $A B$ & PL & \\
\hline Gupta et al. & $C A D$ & azi & $3-6 d$ & $18 \mathrm{mo}$ & 60 & 40 & 20 & $\downarrow C V E$ \\
\hline ISAR-3 & stent & roxi & $4 w$ & $12 \mathrm{mo}$ & 1,010 & 506 & 504 & $\downarrow$ restemosis \\
\hline CLAREYY ${ }^{108}$ & ACS & clarii & $3 \mathrm{mo}$ & $18 \mathrm{mo}$ & 148 & 74 & 74 & $\downarrow$ CVE \\
\hline \multirow[t]{2}{*}{ STAMINA $^{10 ?}$} & ACS & azi & $3 d$ & $12 \mathrm{mo}$ & 325 & 111 & 107 & $\downarrow C V E$ \\
\hline & & amoxi & $1 w$ & & & 107 & & \\
\hline Wiesli et a! ${ }^{109}$ & PAD & roxi & $4 w$ & $20 \mathrm{mo}$ & 40 & 20 & 20 & $\downarrow$ PAD events \\
\hline ROX1S ${ }^{125}$ & ACS & roxi & $30 \mathrm{~d}$ & $6 \mathrm{mo}$ & 202 & 102 & 100 & $=$ CVE \\
\hline ACADEMIC 102 & $C A D$ & $a z i$ & $3 \mathrm{mo}$ & 24 mo & 302 & 150 & 152 & $=C V E$ \\
\hline ANTIBIO 113 & ACS & roxi & $6 w$ & $12 \mathrm{mo}$ & 872 & 433 & 439 & $=$ CVE \\
\hline WIZARD $^{112}$ & CAD & azi & $3 \mathrm{mo}$ & $24 \mathrm{mo}$ & 7,722 & 3,866 & 3,856 & $=$ CVE \\
\hline AZACS & $A C S$ & azi & $5 d$ & $24 \mathrm{mo}$ & 4.439 & 716 & 723 & $=C V E$ \\
\hline Berg ef $a l^{117}$ & CAD & clarí & $16 d$ & $24 \mathrm{mo}$ & 473 & 238 & 235 & $=C V E$ \\
\hline$S P A C E^{118}$ & PAD & $a z i$ & $3 d$ & $24 \mathrm{mo}$ & 509 & 257 & 252 & $=C V E$ \\
\hline$A C E S^{120}$ & CAD & azi & $12 \mathrm{mo}$ & $47 \mathrm{mo}$ & 4,012 & 2,004 & 2,008 & $=C V E$ \\
\hline PROVE-IT-TIMI & ACS & gati & $24 \mathrm{mo}$ & $24 \mathrm{mo}$ & 4,162 & 2,076 & 2,086 & $=$ CVE \\
\hline \multirow{3}{*}{\multicolumn{4}{|c|}{$\begin{array}{l}\mathrm{N} \text { of patients in positive climical endpoint trials } \\
\mathrm{N} \text { of patients in negative clinical endpoint trials } \\
\mathrm{N} \text { of patients in all clinical endpoint trials }\end{array}$}} & & 1,583 & 858 & 725 & $\downarrow$ CVE \\
\hline & & & & & 19,693 & 9,842 & 9,851 & $=\mathrm{CVE}$ \\
\hline & & & & & 21,276 & 10,700 & 10,576 & \\
\hline
\end{tabular}

$A b$ : antibiotic; $A B$ : antibiotic group; $A C S$ : acute coronary syndromes; amoxi: amoxicylin; azi: azithromycin; $\mathrm{CAD}$ : stable coronary artery disease; clari: clarithromycin; CVE: cardiovascular event; d; dlays; gati: gatifloxacin; mo months; PAD: peripheral arterial disease; PL: placebo group: roxi: roxithromycin; w: weeks, " $=$ ": no effect; " $\downarrow$ ": reduced.

Overall these data suggest that antibiotics are not able to reduce cardiovascular risk in atherosclerotic patients. Indeed, the latest meta-analysis involving all randomized clinical trials that have included patients with coronary artery disease showed a lack of effect of antibiotics on cardiovascular risk. ${ }^{122}$ In light of the strong evidence in favour of involvement of Chlamydia pneumoniae in the development of atherosclerosis, the negative results of the clinical trials may be related to the inability to select patients with clinically relevant (vascular) Chlamydia pneumoniae infection, to insufficient study medication, or to wrong timing of antibiotic treatment during the course of atherosclerosis development. In fact, effective treatment of chronic (vascular) Chlamydia pneumoniae infection may be more troublesome than initially anticipated. Recent in vitro evidence suggests that Chlamydia pneumoniae carried within 
macrophages is refractory to anti-chlamydial antibiotics ${ }^{123}$ and that even prolonged antibiotic treatment failed to completely eliminate Chlamydia pneumoniae from infected epithelial cells. ${ }^{124}$ It may therefore not be surprising that the prolonged treatment strategies, varying from 3 to 24 months, employed in the recently published megla-trials have not resulted in a significant reduction of cardiovascular events. ${ }^{112,119,120}$ Considering the fact that in animals the Chlamydia pneumoniae related progression of atherosclerosis can only be prevented by antibiotics when they are administered within 5 days of inoculation of the animals, and that in humans the majority of Chlamydia pneumoniae respiratory tract infections remain clinically unnoticed whereas Chlamydia pneumoniae antibody titres rise already during early childhood, it might be concluded that antibiotics may only contribute to cardiovascular risk reduction when administered early in life as part of a primary preventive strategy.

\subsection{Synopsis and perspectives for the future}

The long standing theory that inflammation and infections play a role in atherosclerosis development has been supported by substantial recent scientific evidence. The data presented in this thesis fit into this recent inflammatory paradigm for atherosclerosis development.

It has been demonstrated that the acute phase reactant CRP was related to the extent of peripheral arterial disease and of abdominal aortic aneurysms. Furthermore, the serum CRP concentration proved to be an independent strong predictor of future cardiovascular events in patients with PAD. Additionally, it was shown that CRP is produced by atherosclerotic vascular tissue. Since the cardiovascular protective effect of statin therapy is more pronounced when it results in lower plasma CRP levels, unravelling the mechanisms governing vascular CRP production and answering the question whether statins interfere herewith become interesting targets for future work in this field.

Considering the reported limitations in the detection of Chlamydia pneumoniae in patients with cardiovascular disease, an easy-to-use and reliable assay for the detection of Chlamydia pneumoniae antibodies, the enzyme immunoassay, was evaluated and showed excellent agreement with the gold standard serological assay (microimmunofluorescence). Furthermore, it was shown that no correlation existed between serum antibodies and presence of Chlamydia pneumoniae particles in the vascular wall, demonstrating the inability to detect patients with clinically relevant (cardiovascular) Chlamydia pneumoniae infections. Setting out standards for the detection of cardiovascularly relevant Chlamydia pneumoniae infections is an important hurdle to be taken, in order to further studies on the role of infections in atherosclerosis. Despite this 
limitation, we were able to show that Chlamydia pneumoniae serology was related to future cardiovascular events in patients with peripheral arterial disease. Moreover, using patients with carotid artery disease as an in vivo model that allows differentiation of atheroscierotic plaque instability from hypercoagulability, our data suggested that the relation between Chlamydia pneumoniae serology and future events may be related to the pro-coagulant effects of Chlamydia pneumoniae infection rather than to induction of plaque instability per se.

Bearing in mind the variation of genes involved in regulation of immune responses, we assessed the influence of two common polymorphisms of inflammatory genes (CD14 and TLR-4) on atherosclerotic disease progression. Or data indicated that the combined trait of the TLR4-G allele and the CD14 $T T$-genotype had the strongest effect on the extent of atherosclerotic disease, whereas each of these polymorphisms individually was not related to severity of atherosclerotic disease. This illustrates the need to consider the variation of, if possible, all genes involved in the regulation of the immune system, in order to understand the inter-individual differences in susceptibility to the proatherogenic effects of various infectious and inflammatory stimuli.

The novel insights into the pathogenesis of atherosclerosis suggesting that infectious and inflammatory processes play an important role in the development of atherosclerotic disease offered potential new targets for medical intervention. The last part of this thesis describes a randomized clinical trial designed to assess the effect of a 3 day course of azithromycine on the progression of atherosclerosis in patients with peripheral arterial disease. The generated data showed that the short antibiotic treatment has no effect on ankle brachial pressure index or on cardiovascular survival in patients with peripheral arterial disease. Combined with the results of recently published mega trials including thousands of patients with coronary artery disease, these data suggest that antibiotics have no place in the secondary prevention of patients with atherosclerotic disease. Although it appears that anti-inflammatory statin treatment may find its way into the therapeutic arsenal of cardiovascular physicians, it remains to be seen whether selected subgroups of patients may benefit from antibiotics as part of a secondary or even primary preventive strategy. 


\subsection{References}

1. Anderson JL, Carlquist JF, Muhlestein JB, Horne BD, Elmer SP. Evaluation of C-reactive protein, an inflammatory marker, and infectious serology as risk factors for coronary artery disease and myocardial infarction. J Am Coll Cardiol, 1998;32:35-41.

2. Ikonomidis I. Andreotti $F$. Economou $E$, Stefanadis $C$. Toutouzas $P$. Nihoyannopoulos $P$. Increased proinflammatory cytokines in patients with chronic stable angina and their reduction by aspirin. Circulation. 1999:100:793-8.

3. Abdelmouttaleb I, Danchin N, llardo C. Aimone-Gastin I, Angioi M, Lozniewski A, Loubinoux $J$, Le Faou A, Gueant $\mathrm{JL}$. C-Reactive pirotein and coronary artery disease: additional evidence of the implication of an inflammatory process in acute coronary symdromes. Am Heart J. 1999; 137:346-51.

4. Erren $M$, Reinecke $H$, Junker $R$, Fobker $M$, Schulte $H$, Schurek JO, Kropf J, Kerber $S$, Breithardt $G$, Assmann $G$, Cullen $P$. Systemic inflammatory parameters in patients with atherosclerosis of the coronary and peripheral arteries. Arterioscler Thromb Wasc Biol. 1999;19:2355-63.

5. Rifai $N$, Joubran $R, Y u H_{*}$ Asmi $M$, Jouma $M$. Inflammatory markers in men with angiographically documented coronary heart disease. Clin Chem. 4999:45:1967-73.

6. De Backer J, Mak $R$, De Bacquer D, Van Renterghem L, Verbraekel $E$, Kornitzer M, De Backer $G$. Parameters of inflammation and infection in a community based case-control study of coronary heart disease. Atherosclerosis. 2002;160:457-63.

7. Brevetti G, Piscione F, Silvestro A, Galasso G, Di Donato A, Oliva G, Scopacasa F, Chiariello $M$. Increased inflammatory status and higher prevalence of three-vessel coronary artery disease in patients with concomitant coronary and peripheral atherosclerosis. Thromb Haemost. 2003;89:1058-63.

8. van Exel $E_{v}$ Gussekloo J, de Craen Ad, Bootsma-van der Wiel $A_{3}$ Frolich $M_{8}$ Westendorp RG. Inflammation and stroke: the Leiden 85-Plus Study. Stroke. 2002;33:1135-8.

9. Pence S, Yilmaz G, Yïlmaz N, Kocoglu H, Namiduru E, Yuncu M, Gokalp N. Determination of plasma fibronectin and serum C-reactive protein in patients with cerebrovascular events. Int $J$ Clin Pract. 2003;57:91-5.

10. Liuzzo G, Biasucci LM, Gallimore JR, Grillo RL, Rebuzzi AG, Pepys MB, Maseri A. The prognostic value of $C$-reactive protein and serum amyloid a protein in severe unstable angina. N Engl J Med. 1994;331:417-24

11. Thompson SG, Kienast $J_{k}$ Pyke SD. Haverkate $F$, van de Loo JC. Hemostatic factors and the risk of myocardial infarction or sudden death in patients with angina pectoris. European Concerted Action on Thirombosis and Disabilities Angina Pectoris Study Group. $N$ Engl $d$ Med. 1995:332:635-41.

12. Haverkate F, Thompson SG, Pyke SD, Gallimore JR, Pepys MB. Prodiuction of C-reactive protein and risk of coronary events in stable and unstable angina. European Concerted Action on Thrombosis and Disabilities Angina Pectoris Study Group. Lancet. 1997:349:462-6.

13. Toss $H_{*}$ Lindahl $B$, Siegbahn $A_{1}$ Wallentin L. Prognostic influence of increased fibrinogen and C-reactive protein levels in unstable coronary artery disease. FRISC Study Group. Fragmin during Instability in Coronary Artery Disease. Circulation. 1997;96:4204-10.

14. Morrow DA, Rifai N, Antman EM, Weiner DL, McCabe CH, Cannon CP, Braunwald E. C. reactive protein is a potent predictor of mortality independently of and in combination with troponim $T$ in acute coronary syndromes: a TIMI 11A substudy. Thrombolysis in Myocardial Infarction. J Am Coll Cardiol. 1998;31:1460-5.

15. Biasucci LM, Liuzzo G, Grillo RL, Caligiuri $G$, Rebuzzi $A G$, Buffon $A$, Summaria $F$, Ginnetti $F$, Fadda $G$, Maseri A. Elevated Levels of C-Reactive Protein at Discharge in Patients With Unstable Angina Predict Recurrent Instability. Circulation. 1999;99:855-60.

16. Ferreiros $E R$ B Boissonnet $C P$, Pizarro $R$, Merletti PF, Corrado $G$, Cagide $A$, Bazzino $O O$. Independent prognostic value of elevated C-reactive protein in unstable angina. Circulation. $1999 ; 100: 1958-63$ 
17. Milazzo D, Biasucci LM, Lucian N, Martinelli L. Canosa $C$, Schiavello $R_{\text {, }}$ Maseri A, Possati G. Elevated levels of $\mathrm{C}$-reactive protein before coronary artery bypass grafting predict recurrence of ischemic events. Am J Cardiol. 1999;84:459-61, A9

18. Buffon $A, L i u z z o ~ G$, Biasucci $L M$, Pasqualetti $P$, Ramazzotti $V$, Rebuzzi $A G$, Crea $F$, Maseri A. Preprocedural serum levels of C-reactive protein predict early complications and late restenosis after coronary angioplasty. I Am Coll Cardiol. 1999;34:1512-21.

19. Heeschen $C$. Hamm $C W$, Bruemmer $J$, Simoons ML. Predictive value of C-reactive protein and troponin $\pi$ in patients with unstable angina: a comparative analysis. CAPTURE Investigators. Chimeric c7E3 AntiPlatelet Therapy in Unstable angina REfractory to standard treatment trial. J Am Coll Cardiol, 2000;35:1535-42.

20. Lindahl $B$, Toss $H$, Slegbahn $A$, Venge $P$, Wallentin $L$. Markers of myocardial damage and inflammation in relation to long-term mortality in unstable coronary artery disease. FRISC Study Group. Fragmin during Instability in Coronary Artery Disease. $N$ Engl $I$ Med. $2000 ; 343: 1139-47$.

21. Chew DP, Bhatt DL, Robbins MA, Penn MS, Schneider JP, Lauer MS, Topol EJ, Ellis SG. Incremental prognostic value of elevated baseline C-reactive protein among established markers of risk in perculaneous coronary intervention. Circulation. 2001:104:992-7.

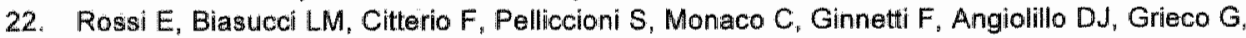
Liuzzo $G$, Maseri $A$. Risk of myocardial infarction and angina in patients with severe peripheral vascular disease: predictive role of C-reactive protein. Circulation. 2002;105:800-3.

23. Kuller LH, Tracy RP, Shaten $J$, Meilahn EN. Relation of C-reactive protein and coronary heart disease in the MRFIT nested case-control study. Multiple Risk Factor Intervention Trial. Am J Epidemiol. 1996;144:537-47.

24. Ridker PM, Cushman $M$, Stampfer MJ, Tracy RP, Hennekens $C H$. Inflammation, aspirim, and the risk of cardiovascular disease in apparently healthy men. N Eng/ IMed.1997;336:973-9.

25. Tracy RP, Lemaitre RN, Psaty BM, Ives DG, Evans RW, Cushman M, Meilahn EN, Kuller LH. Relationship of $\mathrm{C}$-reactive protein to risk of cardiovascular disease in the elderly. Results from the Cardiovascular Health Study and the Rural Health Promotion Project. Arterioscler Thromb Vase Biol. 1997:17:1121-7.

26. Ridker PM, Cushman Mo Stampfer MJ, Tracy RP, Hennekens CH. Plasma concentration of C-reactive protein and risk of developing peripheral vascular disease. Circulation. 1998;97:425-8.

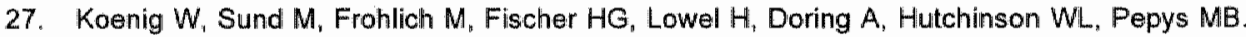
C-Reactive protein, a sensitive marker of inflammation, predicts future risk of coronary heart disease in initially healthy middle-aged men: results from the MONICA (Monitoring Trends and Determinants in Cardiovascular Disease) Augsburg Cohort Study, 1984 to 1992 Circulation. 1999;99:237-42.

28. Harris TB, Ferrucci L, Tracy RP. Corti MC, Wacholder $S$, Ettinger WH, Jir., Heimovitz $H$, Cohen $H J$, Wallace R. Associations of elewated interleukin-6 and C-reactive protein levels with imortality in the elderly. Am J/Med. 1999;106:506-12.

29. Mendall MA, Strachan DP, Butland BK, Ballam Li, Morris J, Sweetnam PM, Elwood PC. Creactive protein: relation to total mortality, cardiovascular mortality and cardiovascular risk factors in men. Eur Heart J. 2000;21:1584-90.

30. Danesh $\mathrm{J}$, Whincup $P$, Walker $M$, Lennon $L$, Thomson $A$, Appleby $P$, Gallimore $J R$, Pepys MB. Low grade inflammation and coronary heart disease: prospective study and updated meta-analyses. Bmi. 2000;321:199-204.

31. Roivainen $M$, Viik-Kajander $M$, Palosuo $T$, Toivanen $P$, Leinonen $M$, Saikku $P$, Tenkanen $L$, Manninen $V$. Hovi $T$. Manttari $M$. Infections, inflammation, and the risk of coronary heart disease. Circulation. 2000;101:252-7.

32. Gussekloo J, Sclhaap MC, Frolich M, Blauw GJ, Westendorp RG. C-reactive protein is a strong but nonspecific risk factor of fatal stroke in elderly persons. Anterioscter Thromb Vasc Biol. 2000;20:1047-5

33. Ridker $P M$, Hennekens $C H$, Buring $J E$, Rifai $N$. C-reactive protein and other markers of inflammation in the prediction of cardiovascular disease in women. $N$ Engl $/$ Med. $2000 ; 342: 836-43$. 
34. Rost NS, Wolf PA, Kase CS, Kelly-Hayes M, Silbershatz H, Massaro JM, DAgostino RB, Franzblau $\mathrm{C}$, Wilson PW. Plasma concentration of C-reactive protein and risk of ischemic stroke and transient ischemic attack: the Framingham study. Stroke. 2001;32:2575-9.

35. Lowe GD, Yarnell JW, Rumley A, Bainton D, Sweetnam PM. C-reactive protein, fibrin Ddimer, and incident ischemic heart disease in the Speedwell study: are inflammation and fibrin turnover linked in pathogenesis? Arterioscler Thromb Vasc Biol. 2001;21:603-10.

36. Pradhan AD, Manson JE, Rossouw JE, Siscovick DS, Mouton CP, Rifai N, Wallace RB, Jackson RD, Pettinger MB, Ridker PM. Inflammatory biomarkers, hormone replacement therapy "and incident coronary heart disease: prospective analysis from the Women's Health Initiative observational study. JAMA. 2002;288:980-7.

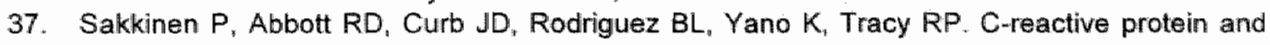
myocardial infarction. J/Clin Epidemiol. 2002;55:445-51.

38. McDermott MM, Green D, Greenland P, Liu K, Criqui MH, Chan C, Guralnik JM, Pearce WH, Ridker PM, Taylor L, Rifai N, Schneider JR. Relation of levels of hemostatic factors and inflammatory markers to the ankle brachial index. Am J Cardio/. 2003;92:194-9.

39. McDermott MM, Greenland P, Green D, Guralnik JM, Criqui MH, Liu K, Chan C, Pearce WH, Taylor L. Ridker PM, Schneider JR, Martin G, Rifai N, Quann M, Fornage M. D-dimer, inflammatory markers, and lower extremity functioning in patients with and without peripheral arterial disease. Circulation. 2003;107:3191-8.

40. Brevetti $G$, Silvestro $A$, Di Giacomo $S$, Bucur $R$, Di Donato $A$, Schiano $V$, Scopacasa $F$. Endothelial dysfunction in peripheral arterial disease is related to increase in plasma markers of inflammation and severity of peripheral circulatory impairment but not to classic risk factors and atherosclerotic burden. $J$ Vase Surg. 2003:38:374-9.

41. Ridker PM. Clinical application of C-reactive protein for cardiovascular disease detection and prevention. Circulation 2003;107:363-9.

42. Blake GJ, Ridker PM. C-reactive protein: a surrogate risk marker or mediator of atherothrombosis? Am J Physiol Regul Integr Comp Physiol. 2003;2003:R1250-2.

43. Yasojima $K$, Schwab $C$, McGeer EG. McGeer PL. Human neurons generate C-reactive protein and amyloid P. upregulation in Alzheimer's disease. Brain Res. 2000;887:80-9.

44. Dong Q, Wright JR. Expression of C-reactive protein by alveolar macrophages. $J / m m u n o /$. 1996;156:4815-20.

45. Jabs WJ, Logering BA, Gerke P. Kreft B, Wolber EM, Klinger MH kidney as a second site of human C-reactive protein formation in vivo. Eur $J$ Immunol. 2003;33:152-61.

46. Yasojima K, Schwab C. McGeer EG, McGeer PL. Human theart generates complement proteins that are upregulated and activated after myocardial infarction. Circ Res. 1998;83:860-9.

47. Kuta $A E$. Baum LL. C-reactive protein is produced by a small number of normal human peripheral blood lymphocytes. JExp Med. 1986;164:321:6.

48. Ikuta $T$, Okubo $H$, Ishibashi $H$, Okumura $Y$, Hayashida $K$. Human lymphocytes synthesize $C-$ reactive protein. Inflammation. 1986;10:223-32.

49. Kolb-Bachofen $V$ "Puchta-Teudt $N$, Egenhofer $C$. Expression of membrane-associated $C$ reactive protein by human monocytes: indications for a selectin-like activity participating in adhesion. Glycoconj $J$ l 1995;12:122-7.

50. Yasojima $K_{1}$ Schwab C. McGeer EG, McGeer PL. Generation of C-reactive protein and complement components in atherosclerotic plaques. Am J Pathol. 2001;158:1039-51.

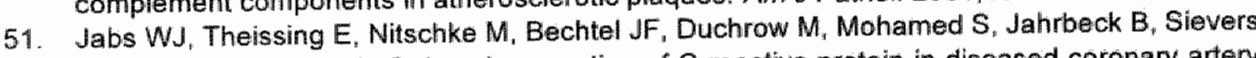

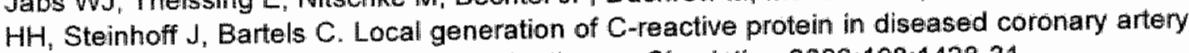
venous bypass grafts and normal vascular tissue. Circulation. 2003;108:1428-31.

52. Calabro $\mathrm{P}$, Willerson JT, Yeh ET. Inflammatory cytokines stimulated C-reactive protein production by human coronary artery smooth muscle cells. Circulation. 2003;108: 1930-2.

53. Venugopal SK, Devaraj S, Jialal I. Macrophage conditioned medium induces the expression of C-reactive protein in human aortic endothelial cells: poteintial for paracrine/autocrine effects. Am J Pathol. 2005:166:1265-71 
54. Siscovick DS, Schwartz SM, Caps M. Wang SP, Grayston JT. Chlamydia pneumoniae and atherosclerotic risk in populations: the role of seroepidemiology. J/nfect Dis. 2000;181 Suppl $3: 5417-20$.

55. Grayston JT, Kuo CC. Wang SP, Altman J. A new Chlamydia psittaci strain, TWAR, isolated in acute respiratory tract infections. $N$ Eng/ $J$ Med. 1986;315:161-8.

56. Kauppinen $M$, Saikku $\mathbb{P}$. Pneumonia due to Chlamydia pneumoniae: prevalence, clinical features, diagnosis, and treatment. Clin Infect Dis. 1995:21 Suppl 3:S244-52.

57. Peeling RW, Wang SP. Graystion. JT, Blasi $F$, Boman $J$, Clad A, Freidank $H$, Gaydos $C A$, Gnarpe J, Hagiwara $T$, Jones RB; Orfila J, Persson K, Puolakkainen M, Saikku P, Schachter J. Chlamydia pneumoniae serology: interlaboratory variation in microimmunoftuorescence assay results. J Infect Dis. 2000;181 Suppl 3:5426-9.

58. Campbell $L A$, Kuo CC. Chlamydia pneumoniae-an infectious risk factor for atherosclerosis? Nat Rev Microbiol, 2004;2:23-32.

59. Leinonen $M$, Saikku $P$. Evidence for infectious agents in cardiovascular disease and atherosclerosis. Lancet Infect Dis. 2002;2:11-7.

60. Bloemenkanp DG, Mall WP, Visseren FL, van der Graaf Y. Meta-analysis of seroepidemiologic studies of the relation between Chlamydia pneumoniae and atherosclerosis: does study design influence results? Am Heart $J .2003 ; 145: 409-17$.

61. Agmon $Y$, Khandheria BK, Meissner I, Petterson TM, O'Fallon WM, Christianson TJ, Wiebers $\mathrm{DO}_{i}$ Smith TF, Steckelberg JM, Tajik AJ. Lack of association between Chlamydia pneumoniae seropositivity and aortic atherosclerotic plaques: a popullation-based transesophageal echocardiographic study. J Am Call Cardiol 2003:41:1482-7.

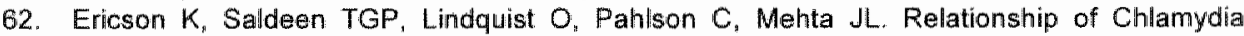
pneumoniae Infection to Severity of Human Coronary Atherosclerosis. Circulation. 2000;101:2568-71.

63. Maass M, Krause E, Engel PM, Kruger S. Endowascular presence of Chlamydia pneumoniae in patients with hemodynamically effective carotid artery stenosis. Angiology. 1997:48: 699-706.

64. Thomas M, Wong $Y$, Thomas $D$, Ajaz M, Tsang V, Gallagher PJ, Ward ME. Relation between direct detection of Chlamydia pneumoniae DNA in human coronary arteries at postmortem examination and histological severity (Stary grading) of associated atherosclerotic plaque. Circulation. 1999;99:2733-6.

65. Tutuncu NB, Guvener $N$, Tutuncu T, Yilmaz $M$, Guvener $M$, Boke E, Pasaoglu 1, Erbas T. Chtamydia pneumonia seropositivity correlates with serum fibrinogen and lipoprotein a levels: any role in atherasclerosis? Endocr J. 2001;48:269-74

66. Torgano $G$. Cosentini R, Mandelli $G$, Perondi R, Blasi $F$, Bertinieri $G$, Tien TV, Ceriani $G$, Tarsia P. Arasio C, Ranzi ML. Treatment of Helicobacter pylori and Chlamydia pneumoniae infections decreases fibrinogen plasma level in patients with ischemic heart disease. Circulation. 1999:99:1555-9.

67. Netea MG, Kullberg BJ, Galama JM, Stalenhoef AF, Dinarello CA, Van der Meer JW. NonLPS components of Chlamydia pneumoniae stimulate cytokine production through Toll-like receptor 2-dependent pathways. Eur I/mmunol. 2002;32:1188-95.

68. Kalayoglu MV, Byrne Gl. Induction of macrophage foam cell formation by Chlamydia pneumoniae. J Infect Dis 1998;177:725-9

69. Laurila $A$, Bloigu $A$, Nayha $S$, Hassi $J$, Leinonen $M$, Saikku $P$. Chronic Chlamydia pneumoniae infection is associated with a serum lipid profile known to be a risk factor for atherosclerosis. Anterioscler Thromb Vasc Biol. 1997:17:2910-3.

70. Mayr M. Metzler B, Klechl S, Willeit J, Schett G, Xu Q. Wick G. Endothelial cytotoxicity mediated by serum antibodies to heat shock proteins of Escherichia coli and Chlamydia pneumoniae: immune reactions to heat shock proteins as a possible link between infection and atherosclerosis. Ciroulation. 1999,99:1560-6.

71. Espinola-Klein C, Rupprecht HJ, Blankenberg S, Bickel C, Kopp H, Rippin G, Victor A, Hafner $G_{3}$ Schlumberger $W$, Meyer J. Impact of infectious burden on extent and long-term prognosis of atherosclerosis. Circulation. 2002:105:15-21. 
72. Bloemenkamp DG, Mali WP, Tanis BC, Rosendaal FR, van den Bosch MA, Kemmeren JM, Algra A, Ossewaarde JM, Visseren FL, wan Loon AM, van der Graaf $Y$. Chlamydia pneumoniae. Helicobacter pylori and cytomegalovirus infections and the risk of peripheral arterial disease in young women. Atherosclerosis. 2002;163:149-56.

73. Ngeh J, Goodbourn C. Chlamydia pneumoniae, Mycopllasma pneumoniae, and Legionella pneumophila in elderly patients with stroke (C-PEPS, M-PEPS, L-PEPS): a case-control study on the infectious burden of atypical respiratory pathogens in elderly patients with acute cerebrovascular disease. Stroke 2005;36:259-65.

74. Huittinen $T$, Leinonen $M$, Tenikanen $L$, Virkkunen $H_{3}$ Manttari $M$, Palosuo $T$, Manninen $V$, Saikku P. Synergistic effect of persistent Chiamydia pneumoniae infection ${ }_{4}$ autoimmunity ${ }_{1}$ and inflammation on coronary risk. Circulation. 2003:107:2566-70.

75. Arbour NC, Lorenz E, Schutte BC, Zabner J, Kline JN, Jones $M$, Frees $K$, Watt JL, Sehwartz DA. TLR4 mutations are associated with endotoxin hyporesponsiveness in humans. Nat Genet. 2000;25:187-91.

76. Kiechl $S$, Lorenz $E$, Reindl $M$, Wiedermann $C J$, Oberhollenzer $F$, Bonora $E$, Willeit $J$, Schwartz DA. Toll-like receptor 4 polymorphisms and atherogenesis. $N$ Engl $J$ Med. 2002;347:185-92.

77. Ameziane $N_{n}$ Beillat $T$, Verpillat $P$, Choilet-Martin $S$, Aumont MC, Seknadji $P$, Lamotte $M_{0}$ Lebret $D$, Ollivier $V$, de Prost D. Association of the Toll-like receptor 4 gene Asp299Gly polymorphism with acute coronary events. Arterioscler Thromb Vasc Biol. 2003;23:961-4.

78. Boekholdt SM. Agema WR, Peters RJ, Zwinderman $A H$, van der Wall EE, Reitsima $P H$, Kastelein JJ, Jukema JW. Variants of toll-like receptor 4 modify the efficacy of statin therapy and the risk of cardiovascular events. Circulation. 2003;107:2416-21.

79. Risley $P$, Jerrard-Dunne $\mathbb{P}$, Sitzer $M$, Buehler $A$, von Kegler $S$, Markus HS. Promoter polymorphism in the endotoxin receptor (CD14) is associated with increased carotid atherasclerosis only in smokers: the Carotid Atherosclerosis Progression Study (CAPS). Stroke. 2003;34:600-4.

80. Lichy C, Meiser H, Grond-Ginsbach C, Buggle F, Dorfer C, Grau A. Lipopolysaccharide receptor CD14 polymorphism and risk of stroke in a South-German population. I Neurol. 2002;249:821-3.

81. Hubacek JA, Rothe G, Pitha J, Skodova Z, Stanek V, Poledne R, Schmitz G. C(-260) $\rightarrow>$ T polymorphism in the promoter of the CD14 monocyte receptor gene as a risk factor for myocardial infarction. Circulation 1999;99:3218-20.

82. Shimada $K$, Watanabe $Y$, Mokuno $H$, Iwama $Y$, Daida $H$, Yamaguchi $H$. Common polymorphism in the promoter of the CD14 monocyte receptor gene is associated with acute myocardial infarction in Japanese men. Am, $/$ Cardiol. 2000;86:682-4, AB.

83. Ito $D$, Murata $M$, Tanahashi $N$, Sato $H$, Sonoda $A$, Saito I, Watanabe $K$, Fukuuchi $Y$. Polymorphism in the promoter of lipopolysaccharide receptor CD14 and ischemic cerebrovascular disease. Stroke 2000;31:2661-4.

84. Longobardo $M T$, Cefalu $A B$, Pezzino $F$, Noto $D$, Emmanuele $G$, Barbagallo $C M$, Fiore $B$, Monastero $R$, Castello A, Molini V, Notarbartolo A, Travali $S$, Averna MR. The $C(-260)>T$ gene polymorphism in the promoter of the CD14 monocyte receptor gene is not associated with acute myocardial infarction. Clin Exp Med. 2003;3:161-5.

85. Zee RY, Bates D, Ridker PM. A prospective evaluation of the CD14 and CD18 gene polymorphisms and risk of stroke. Stroke. 2002;33:892-5.

86. Ridker PM, Rifai $N_{n}$ Pfeffer $M A_{v}$ Sacks $F$. Braunwald $E$. Long-term effects of pravastatin on plasma concentration of C-reactive protein. The Cholesterol and Recurrent Events (CARE) Investigators. Circulation. 1999;100:230-5.

87. Ridker PM, Rifai N, Clearfield M, Downs JR, Weis SE, Miles JS, Gotto AM, Jr. Measurement of C-reactive protein for the targeting of statin therapy in the primary prevention of acute coronary events. N Engl JMed. 2001;344:1959-65.

88. Ridker PM, Cannon CP, Morrow D, Rifai N, Rose LM, McCabe CH, Pfeffer MA, Braumwald E. C-reactive protein levels and outcomes after statin therapy. N Engl J Med. 2005;352:20-8. 
89. Gupta $S_{\text {i Leatham EW }}$ Carrington D, Mendall MA, Kaski JC, Camm AJ. Elevated Chlamydia pneumoniae antibodies, cardiovascular events, and azithromycin in male survivors of myocardial infarction. Circulation. 1997;96:404-7.

90. Gurfinkel $E_{\text {, Bozovich }} G$, Daroca $A$, Beck E, Mautner B. Randomised trial of roxithromycin in non-Q-wave coronary syndromes: ROXIS Pilot Studly. ROXIS Study Group. Lancet $1997 ; 350: 404 ; 7$.

91. Meier CR, Derby LE, Jick SS, Vasilakis C, Jick H. Antibiotics and risk of subsequent first-time acute myocardial infarction. JAMA. 1999;281:427-31.

92. Herings $\mathrm{RM}_{\text {, Leufkens }} \mathrm{HG}$, Vandenbroucke JP. Acute myocardial infarction and prior antibiotic use. JAMA, 2000;284:2998-9.

93. Ostergaard $L$, Sorensen $H T_{\text {" Lindholt }} \mathrm{J}_{3}$ Sorensen TE, Pedersen $L$, Eriksen $T$, Andersen $P L$. Risk of hospitalization for cardiovascular disease after use of macrolides and penicillins: a comparative prospective cohort study. I/nfect Dis. 2001:183:1625-30.

94. Pilote L, Green L, Joseph L, Richard H. Eisenberg MJ. Antibiotics against Chlamydia pneumoniae and prognosis after acute myocardial infarction. Am Heart J. 2002;143:294-300.

95. Jackson LA, Smith NL. Heckbert SR, Grayston JT, Siscowick DS, Psaty BM. Lack of association between first myocardial infarction and past use of erythromycin, tetracycline, or doxycycline. Emerg Infect Diss. 1999;5:281-4.

96. Luchsinger JA, Pablos-Mendez A, Knirsch C, Rabinowitz D, Shea S. Antibiotic use and risk of ischemic stroke in the elderly. Am J Med. 2001:111:361-6.

97. Luchsinger JA, Pablos-Mendez A, Knirsch C, Rabinowitz D, Shea S. Relation of antibiotic use to risk of myocardial infarction in the general population. Am J Cardiol. 2002;89:18-21.

98. Brassard P. Bourgault C, Brophy J, Kezoulh A. Suissa S. Antibiotics in primary prevention of stroke in the elderly. Stroke. 2003;34:e163-6.

99. Brassard P, Bourgault C, Brophy J, Kezouh A, Rainville $B$, Xhignesse $M_{3}$ suissa S. Antibiotics in primary prevention of myocardial infarction among elderly patients with hypertension. Am Heart $J .2003 ; 145: E 20$.

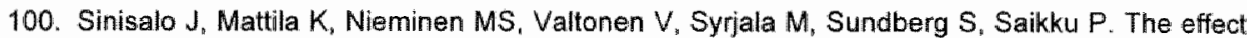
of prolonged doxycycline therapy on Chilamydia pneumoniae serological markers, coronary heart disease risk factors and forearm basal nitric axide production. $J$ Antimicrob chemother. $1998: 41: 85-92$.

101. Melissano $G$, Blasi F, Esposito $G$, Tarsia $P$. Dordoni L, Arasio C, Tshomba $Y$, Fagetti L, Allegra L, Chiesa R. Chlamydia pneumoniae eradication from carotid plaques. Results of an open, randomised treatment study. Eur J Vasc Endovasc Surg. 1999;18:355-9.

102. Muhlestein JB, Anderson JL, Carlquist JF, Salunkhe $\mathrm{K}_{\mathrm{b}}$ Horne BD, Pearson RR, Bunch $T J$, Allen $A$, Trehan $S$, Nielson $C$. Ramdomized secondary prevention trial of azithromycin in patients with coronary artery disease: primary clinical results of the ACADEMIC study. Circulation. 2000;102:1755-60.

103. Jackson LA. Description and status of the azithromycin and coronary events study (ACES). d Infect Dis. 2000;181 Suppl 3:S579-81.

104. Noumann $F$, Kastrati $A$ s Miethke $T$, Pogatsa-Murray $G$, Mehilli $d$, Valina $C$, Jogethaei $N$, da

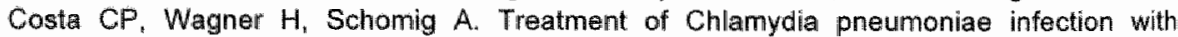
raxithromycin and effect on neointima proliferation after coronary stent placement (ISAR- 3 ): a randomised, double-blind, placebo-controlled trial. Lancet 2001;357:2085-9.

105. Mosorin $M$, Juvonen J, Biancari $F$. Satta J, Surcel HM, Leinonen $M$, Saikku $P$, Juvonen $T$. Use of doxycycline to decrease the growth rate of abdominal aortic aneurysms: A randomized, doublemblind, placebo-controlled pilot study. J Vasc Surg. 2001;34:606-10.

106. Vammen $S$, Lindholt JS, Ostergaard L, Fasting $H$, Henneberg EW. Randomized double-blind controlled trial of roxithromycin for prevention of abdominal aortic aneurysm expansion. $\mathrm{Br} J$ Surg. 2001;88:1066-72.

107. Stone AF, Mendall MA, Kaski JC, Edger TM, Risley P, Poloniecki J, Camm AJ, Northfield TC. Effect of treatment for Chlamydia pneumoniae and Helicobacter pylori on markers of inflanmation and cardiac events in patients with acute coronary syndromes: South Thames Trial of Antibiotics in Myocardial Infarction and Unstable Angina (STAMINA). Circulation. $2002 ; 106: 1219-23$. 


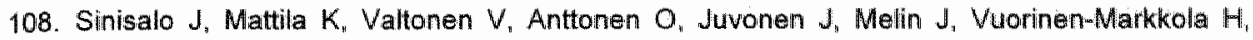
Nieminen MS. Effect of 3 months of antimicrobial treatment with clarithromycin in acute nonq-wave coronary syndrome. Circulation. 2002;105:1555-60.

109. Wiesil $P$, Czerwenka $W$, Meniconi $A$, Maly FE, Hoffmann $U$, Vetter $W$, Schulthess $G$. Roxithromycin treatment prevents progression of peripheral arterial occlusive disease in Chlamydia pneumoniae seropositive men: a randomized, double-blind placebo-controlled trial. Circulation. 2002;105:2646-52.

110. Parchure $N$, Zouridakis EG, Kaski JC. Effect of azithromycin treatment on endothelial function in patients with coronary artery disease and evidence of Chlamydia pneumoniae infection. Circulation. 2002;105:1298-303

111. Axisa $B$, Loftus $\mid M$, Naylor AR, Goodall $S$, Jones L, Bell PR, Thompson MM. Prospective, randomized, double-blind trial investigating the effect of doxycycline on matrix metalloprofeinase expression within atheroscleratic carotid plaques. Stroke. 2002;33: 2858-64.

112. OConnor CM, Dunne MW, Pfeffer MA, Muhlestein AB, Yao L, Gupta S, Benner RJ, Fisher $M R$. Cook TD. Azithromycin for the secondary prevention of coronary heart disease events: the WIZARD study: a randomized controlled trial. JAMA. 2003;290:1459-66.

113. Zahn $R$, Schneider $S$, Frilling $B$, Seidl $K$, Tebbe U, Weber $M$, Gottwik M, Altmann E, Seidel F, Rox J. Hoffler U. Neuhaus K-L, Senges J, for the Arbeitsgemeinschaft Leitender Kardiologischer Krankenhausarzte (Working Group of Leading Hospital Cardiologists; ALKK). Antibiotic Therapy After Acute Myocardial Infarction: A Prospectiva Randomized Study. Circulation. 2003;107:1253-1259.

114. Cercek B, Shah PK, Noc M, Zahger D, Zeymer U, Matetzky S, Maurer G, Mahrer P. Effect of short-term treatment with azithromycin on recurrent ischaemic events in patients with acute coronary syndrome in the Azithromycin in Acute Coronary Syndrome (AZACS) trial: a randomised controlled trial. Lancet: 2003;361:809-13.

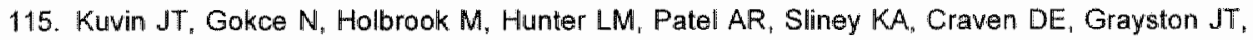
Keaney JF, Jr., Karas RH, Vita JA. Effect of short-term antibiotic treatment on Chlamydia pneumoniae and peripheral endothelial function. Am J Cardiol. 2003:91:732-5.

116. Sander $D$, Winbeck $K$, Klingelhofer J, Etgen $T$, Conrad B. Progression of early carotid atherosclerosis is only temporarily reduced after antibiotic treatment of Chlamydia pneumoniae seropositivity. Circulation. 2004:109:1010-5.

117. Berg HF, Maraha B, Scheffer GJ, Quarles-van Ufford $M_{1}$. Vandenbroucke-Grauls CM, Peeters MF, Klluytmans JA. Treatment with clarithromycin prior to coronary artery bypass graft surgery does not prevent subsequent cardiac events. Clir infect Dis. 2005;40:358-65.

118. Vainas $T$, Stassen FR, Schurink GW, Tordoir JH, Waiten RJ, van den Akker LH, Kurvers HA, Bruggeman CA, Kitslaar PJ. Secondary Prevention of Atherosclerosis Through Chlanydia pneumoniae Eradication (SPACE Trial): A Randomised Clinical Trial in Patients with Peripheral Arterial Disease. Eur J Vasc Endovasc Surg. 2005;29:403-11.

119. Camnon CP, Braunwald E, McCabe CH, Grayston JT. Muhlestein B, Giugliano RP "Cairns R. Skene AM. Antibiotic treatment of Chlamydia pneumoniae after acute coronary syndrome. $N$ Engl J Med 2005; 352:16.46-54.

120. Grayston JT, Kronmal RA, Jackson LA, Parisi AF, Muhlestein JB, Cohen JD, Rogers W. Crouse JR, Borrowdale SL, Schron $E_{\text {a }}$ Knirsch C. Azithromycin for the secondary prevention of coronary events. N Engl J Med. 2005;352:1637-45.

121. Sander D, Winbeck K, Klingelhofer J, Etgen T, Conrad B. Reduced progression of early carotid atherosclerosis after antibiotic treatment and Chlamydia pneumoniae seropositivity. Circulation. 2002;106:2428-33.

122. Andraws $R$, Berger JS, Brown DL. Effects of antibiotic therapy on outcomes of patients with coronary artery disease: a meta-analysis of randomized controlled trials. JAMA. 2005;293:2641-7.

123. Gieffers J, Fullgraf $H$, Jahn J, Klinger $M$, Dalhoff $K_{v}$ Katus $H A$, Solbach $W$, Maass $M$. Chlamydia pneumoniae infection in circulating human monocytes is refractory to antibiotic treatment. Circulation. 2001:103:351-6. 
124. Kutlin A, Roblin PM, Hammerschlag MR. Effect of Prolonged Treatment with Azithromycin, Clarithromycin, or Levofloxacin on Chlamydia pneumoniae in a Continuous-Infection Model. Antimicrob Agents Chemother. 2002;46:409-12.

125. Guifinkel E, Bozovich G, Beck E. Testa E. Livellara B, Mautner B. Treatment with the antibiotic roxithromycin in patients with acute non- $Q$-wave coronary syndromes. The final report of the ROXIS Studly. Eur Heart J. 1999;20:121-7. 
Summary 
162 


\section{Summary}

In this thesis the inflammatory and infectious features of atherosclerosis are scrutinized. Chapter 1 lays out the theoretical background of the studies described here. A comprehensive overview of the pathogenesis and epidemiology of atheroscierotic disease is given with special emphasis on the inflammatory nature of this process and the potential involvement of infectious microbes herein. Also a short historical overview of the developments in atherosclerotic cardiovascular medicine is given, commemorating the tremendous achievements of the past in this field.

Section 2 (inflammation and atherosclerosis, chapters $2 \& 3$ ) deals with the relation between CRP and (extent of) atherosclerotic disease. In Chapter 2, serum CRP was measured highly sensitive in patients with peripheral arterial disease, showing and inverse relation to ankle-brachial pressure index. Baseline serum CRP was also related to future cardiovascular events. Furthermore, femoral plaques have shown to be able to produce CRP. Immunohistochemical analysis located the vascular CRP production on macrophages, T-cells and smooth muscle cells. Similarly, in chapter 3 it was shown that serum CRP was related to the dimension of abdominal aortic aneurysms and that aneurysmal tissue produces CRP.

In section 3 (infection and atherosclerosis, chapters 4-6) the role of Chlamydia pneumoniae infection in peripheral vascular disease was studied. In chapter 4 . Chlamydia pneumoniae IgA and IgG antibodies were measured with a commercially available enzyme immunoassay and with the microimmunofluorescence test, which has been regarded the gold standard for detection of Chlamydia pneumoniae antibodies. Our data showed that both tests yielded comparable results for the detection of Chlamydia pneumoniae IgA- and lgG-antibodies in patients with cardiovascular disease. In chapter 5. Chlamydia pneumoniae antibodies were related to the presence of Chlamydia pneumoniae DNA or proteins in atherosclerotic plaques of patients undergoing reconstructive vascular surgery of the aorta, carotid or femoropopliteal arteries. These data demonstrated a lack of association between Chlamydia pneumoniae serology and presence of Chlamydia pneumoniae particles in the vascular wall, rendering serological detection of vascular Chlamydia pneumoniae infection virtually impossible. In chapter 6 we were able to demonstrate that Chlamydia pneumoniae serology was related to hypercoagulability rather than plaque rupture per se, relating Chlamydia pneumoniae antibodies to micro-embolic signals in the middle cerebral artery in patients undergoing carotid endarterectomy for symptomatic carotid artery disease.

In section 4 (chapter 7), common polymorphisms of two pattern-recognition receptor genes, i.e., the Toll-like receptor 4 (TLR4) $+896 A>G$ and the CD14 - 
$260 C>T$ single nucleotide polymorphism were analyzed in relation to total atherosclerosis burden in patients with peripheral arterial disease. Multivariate logistic regression analysis showed that combination of the $T L R 4+896 A>G$ allele carriership and $C D 14-260 T T$ homozygocity was an independent predictor of extensive atherosclerotic disease. This provided an explanation for inter-individual susceptibility to atherosclerosis based on genetic variability of a combination of genes involved in innate immune regulation.

Considering the inflammatory nature of atherosclerosis and the potential modulatory role of (Chlamydia pneumoniae) infections in the development of cardiovascular events, new potential therapeutic (anti-inflammatory or antimicrobial) targets have evolved. In section 5 the effect of a short course of antibiotics in the progression of atherosclerosis in patients with peripheral arterial disease was studied in a randomised clinical trial (chapter 8). Although Chlamydia pneumoniae serology was related to future cardiovascular events, no beneficial effect of a 3-day course of azithromycine on cardiovascular events or changes in ankle-brachial pressure index were observed. In chapter 9 , the main results of this thesis are discussed in relation to the literature.

In conclusion, the data presented are in concord with the inflammatory nature of atherosclerosis. It has been shown that CRP is produced by diseased vascular tissue and that serum CRP is related to the extent of atherosclerotic disease and to future cardiovascular events. Furthermore, it has been suggested that Chlamydia pneumoniae infection can induce a clinically relevant hypercoagulable state, as Chlamydia pneumoniae antibodies were associated with thrombosis related micro-embolization after carotid endarterectomy and with future cardiovascular events in patients with peripheral arterial disease. Despite these associations, a short-term antibiotic treatment had no effect on future events and changes in ankle-brachial pressure index in patients with peripheral arterial disease. 
Samenvatting 


\section{Samenvatting}

In dit proefschrift worden de inflammatoire en infectieuze aspecten van atherosclerose bestudeerd. Deel 1 (Introduction, Hoofdstuk 1) geeft een theoretische achtergrond voor de beschreven studies aan de hand van een overzicht van de pathogenese en epidemiologie van atherosclerotische ziekte. Hierbij ligt de nadruk op de inflammatoire kenmerken van atherosclerose en de mogelijke rol van infectieuze micro-organismen hierin. Tevens wordt een historisch overzicht betreffende de ontwikkelingen in cardiovasculaire geneeskunde gepresenteerd.

Deel 2 (Inflammation and atherosclerosis, hoofdstuk 2 en 3) gaat over de relatie tussen C-reactive protein (CRP) en (de uitgebreidheid van) atherosclerotische ziekte. In hoofdstuk 2 wordt een onderzoek beschreven naar CRP met hoge gevoeligheid (hsCRP) gemeten in het serum van patiënten met perifeer arterieel vaatlijden. Er bleek sprake van een omgekeerde relatie tussen de hoogte van hsCRP en de hoogte van de enkel-arm-index, dat een gevoelige maat is voor de uitgebreidheid van perifeer arterieel vaatlijden. Daarnaast bleek de hsCRP serum concentratie gerelateerd aan het optreden van toekomstige cardiovasculaire complicaties. Uit aanvullende studies bleek dat atherosclerotische plaques uit de liesslagader CRP kunnen produceren. Immunohistochemische analyses suggereerden dat deze CRP productie plaatsvindt in macrophagen, T-cellen en gladde spiercellen. Op overeenkomstige wijze toonde de studie beschreven in hoofdstuk 3 dat de hoogte van hsCRP direct gerelateerd was aan de diameter van aneurysmata van de aorta abdominalis en dat CRP geproduceerd werd door het aneurysmaweefsel zelf. De rol van infectie met het micro-organisme Chlamydia pneumoniae in relatie tot perifeer vaatlijden wordt in deel 3 (Infection and atherosclerosis, hoofdstuk 4-6) beschreven. In hoofdstuk 4 wordt beschreven hoe Chlamydia pneumoniae lgA- en IgG-antilichamen werden gemeten met een commercieel verkrijgbare ELISA en met de micro-immunofluorescentietest, welke als gouden standaard gezien wordt voor het detecteren van Chlamydia pneumoniae antilichamen. Onze data toonden dat beide testen vergelijkbare resultaten opleverden met betrekking tot de detectie van Chlamydia pneumoniae IgA- en IgG-antilichamen in patiënten met cardiovasculaire aandoeningen. De relatie tussen Chlamydia pneumoniae antilichamen in het serum en de aanwezigheid van Chlamydia pneumoniae DNA of proteïnen in atherosclerotisch weefsel van patiënten die een vaatoperatie ondergingen aan de aorta, hals-, lies- of knieslagader wordt in hoofdstuk 5 beschreven. Er werd geen associatie gevonden tussen Chlamydia pneumoniae serologie en aanwezigheid van Chlamydia pneumoniae partikels in de vaatwand. Serologische detectie van vasculaire infectie met Chlamydia pneumoniae is dus waarschijnlijk niet mogelijk. In hoofdstuk 6 wordt beschreven dat 
Chlamydia pneumoniae serologie geassocieerd bleek te zijn met hypercoagulabiliteit en niet met plaque-instabiliteit. Deze conclusie werd gebaseerd op de gevonden associatie tussen Chlamydia pneumoniae seropositiviteit en het aantal thrombus gerelateerde micro-embolieën in de arteria cerebri media bij patiënten die een endarteriëctomie van de halsslagader ondergingen in verband met een symptomatische a.carotis stenose.

Deel 4 (Genetic determinants of atherosclerosis susceptibility, hoofdstuk 7) beschrijft een studie waarin vaak voorkomende DNA-polymorfismen van twee receptoren die onderdeeel uitmaken van het aangeboren immuunsysteem, namelijk de Toll-like receptor 4 (TLR-4) +896 A>G en de CD14 -260 C>T polymorphismen, geanalyseerd werden in relatie tot de algemene uitgebreidheid van atherosclerose in patiënten met perifeer arterieel vaatlijden. Multivariate logischtische regressie analyse toonde dat de combinatie van het TLR4 Asp299Gly G-allel dragerschap en CD14 -260 TT homozygotie een onafhankelijke voorspeller was van uitgebreide atherosclerotische ziekte. Deze uitkomst bood een verklaring voor de inter-individuele ontvankelijkheid voor atherosclerose gebaseerd op genetische variabiliteit van een gencombinatie die van belang is voor de immuunregulatie.

Het inflammatoire karakter van atherosclerose en de mogelijk modulerende rol van (Chlamydia pneumoniae) infecties bij cardiovasculaire ziekten, vormen de theoretische basis voor nieuwe potentiële therapeutische (anti-inflammatoire of anti-microbiële) strategieën. In een prospectief opgezet gerandomiseerde studie werd het effect van een korte antibioticakuur bestudeerd op de progressie van atherosclerose in patiënten met perifeer arterieel vaatlijden (Clinical intervention trial; deel 5, hoofdstuk 8). Hoewel in deze studie de initiële Chlamydia pneumoniae serologie gerelateerd was aan later optredende cardiovasculaire gebeurtenissen, werd er door het geven van een 3-daagse kuur azithromycine geen gunstig effect gemeten op toekomstige cardiovasculaire gebeurtenissen of op veranderingen in de enkel-arm-index, als maat van progressie van perifeer vaatlijden.

Tot slot worden in deel 6 (Discussion, hoofdstuk 9) de belangrijkste resultaten van dit proefschrift bediscussieerd in relatie tot bevindingen uit de literatuur. De gepresenteerde eigen data zijn in overeenstemming met het inflammatoire karakter van atherosclerose. De resultaten van dit proefschrift tonen dat CRP geproduceerd wordt door aneurysmatisch en atherosclerotisch vasculair weefsel en dat CRP, gemeten in het serum, gerelateerd is aan de uitgebreidheid van atherosclerotische ziekte en aan toekomstige cardiovasculaire complicaties. Daarnaast suggereren de hier beschreven studies dat een infectie met Chlamydia pneumoniae een klinisch relevante hypercoagulabele status kan induceren, daar Chlamydia preumoniae antilichamen geassocieerd bleken met het optreden van micro-embolieën na 
endarteriëctomie van de halsslagader en met toekomstige cardiovasculaire gebeurtenissen bij patiënten met perifeer arterieel vaatlijden. Ondanks deze associaties bleek een korte antibioticakuur, bij patiënten met perifeer arterieel vaatlijden, niet effectief in het voorkomen van toekomstige cardiovasculaire complicaties of progressie van perifeer arterieel vaatlijden zoals weergegeven door verandering van de enkel-arm index. 


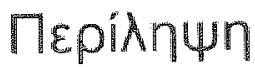


192 


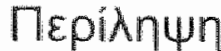

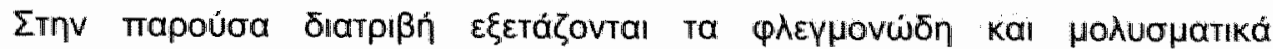

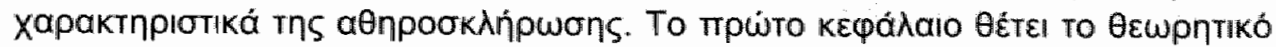

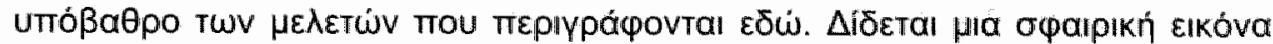

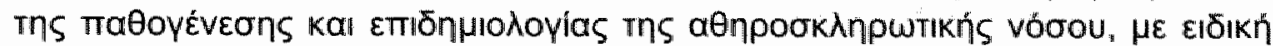

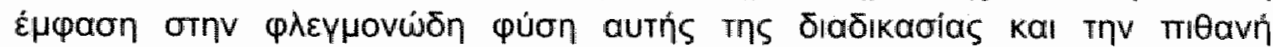

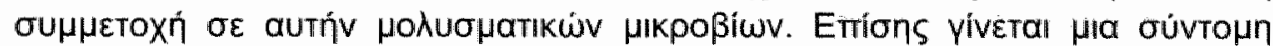

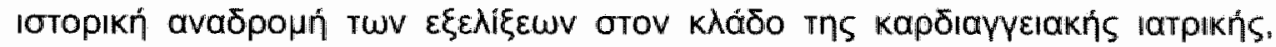

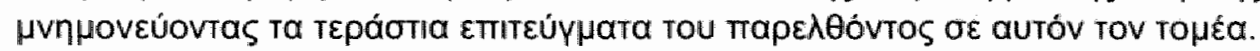

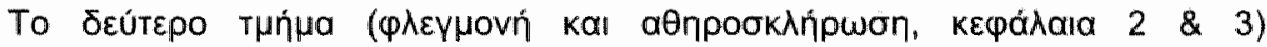

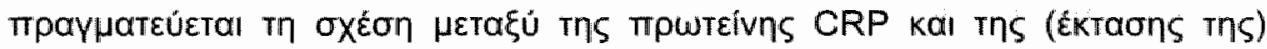

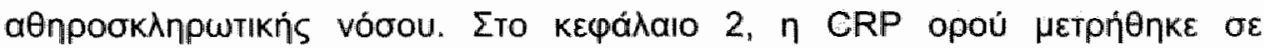

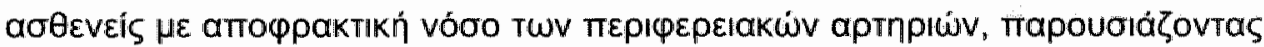

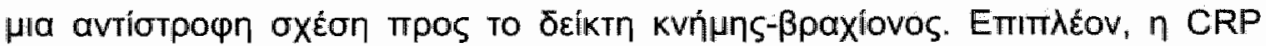

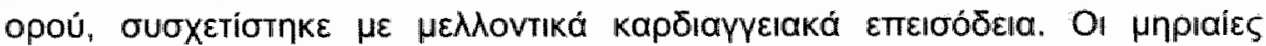

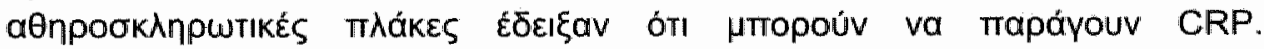

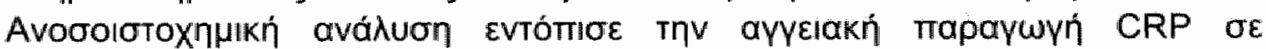

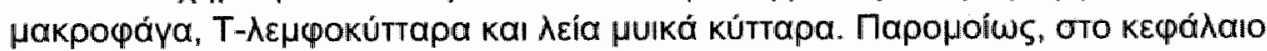

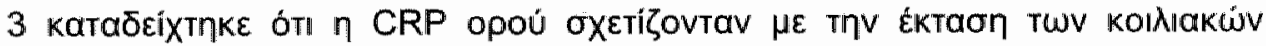

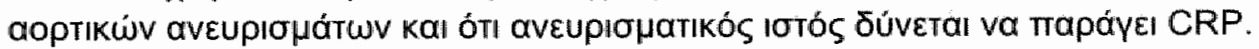

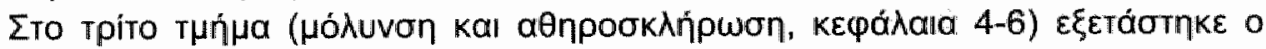

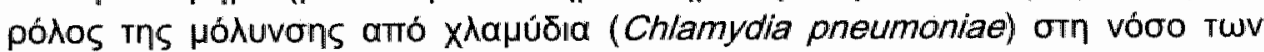

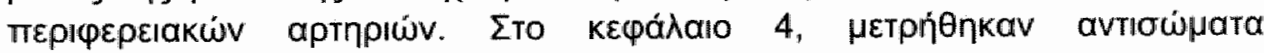

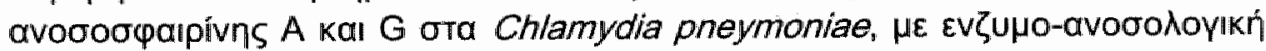

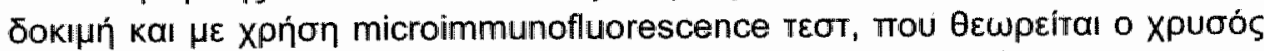

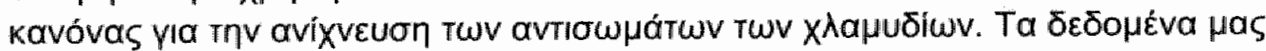

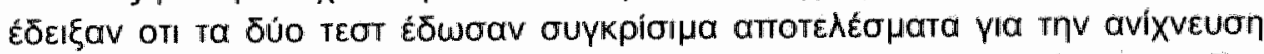

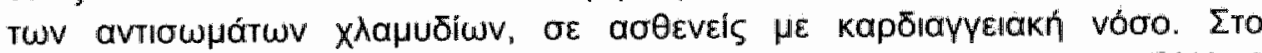

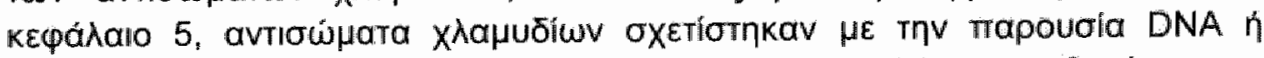

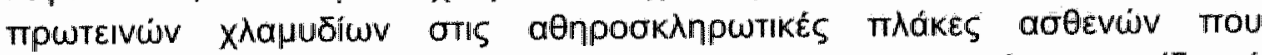

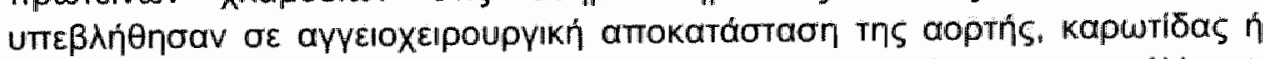

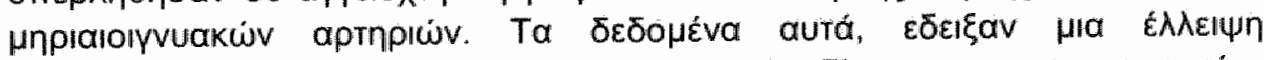

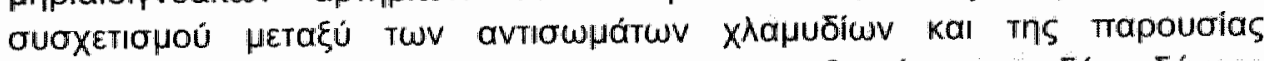

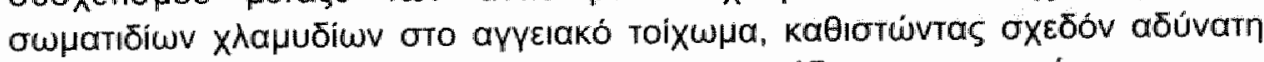

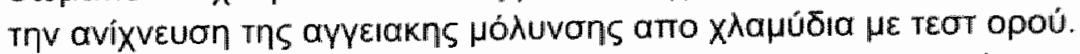

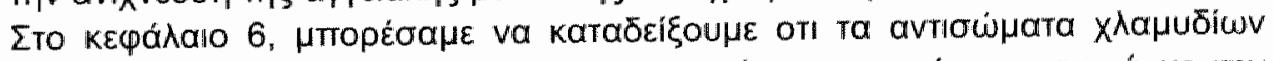

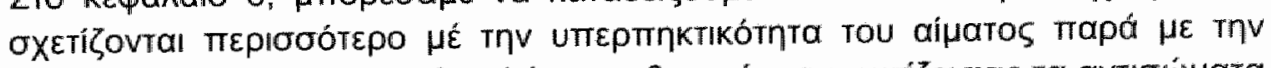

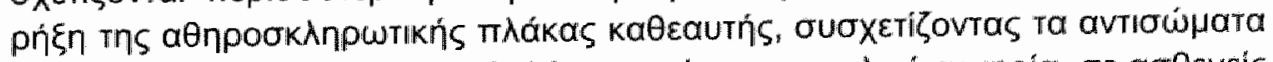

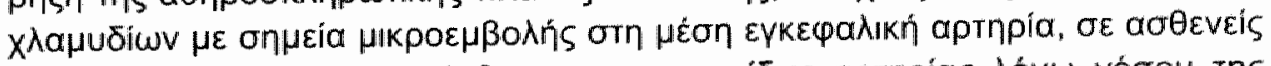

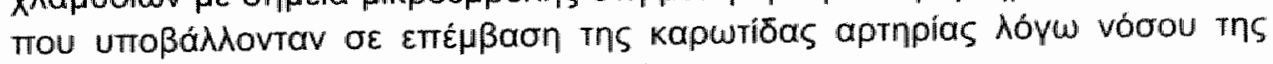

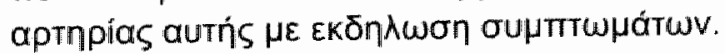




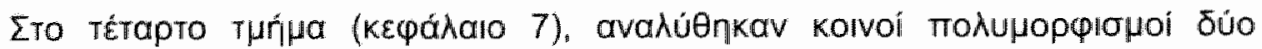

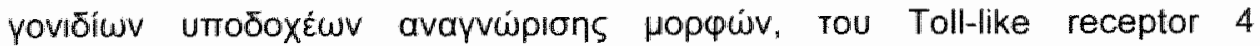

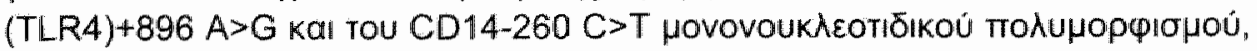

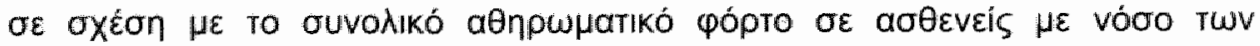

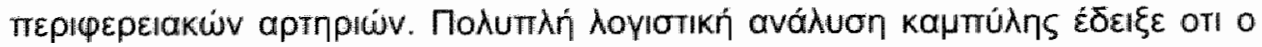

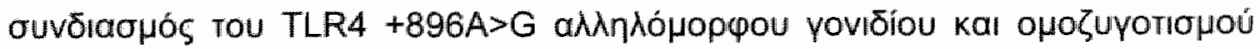

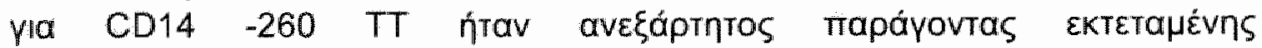

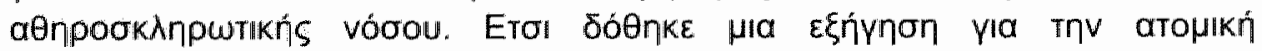

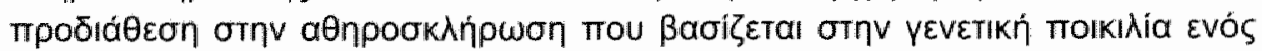

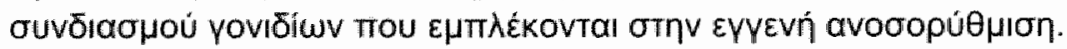

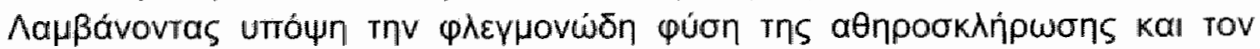

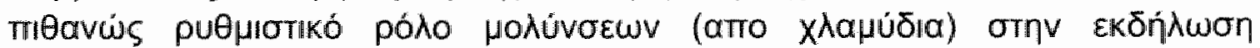

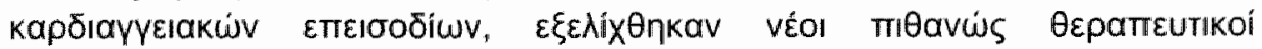

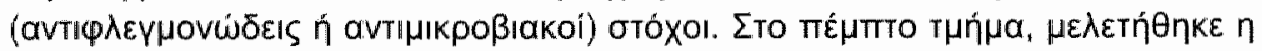

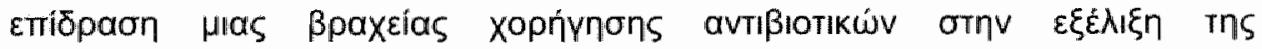

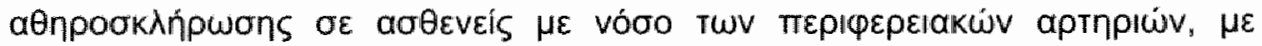

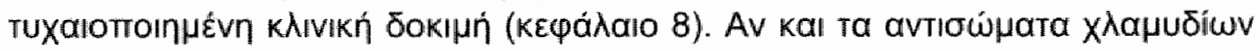

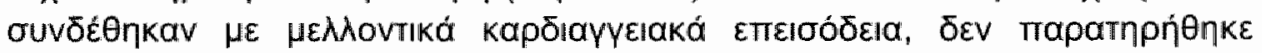

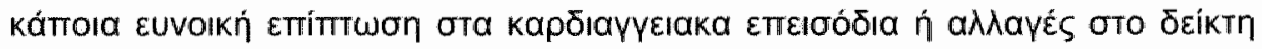

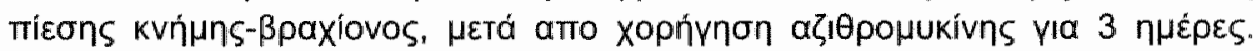

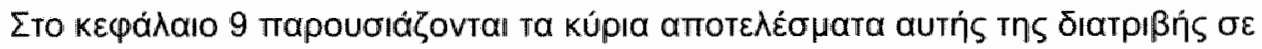
ox $x \dot{\varepsilon} \sigma \eta \eta$

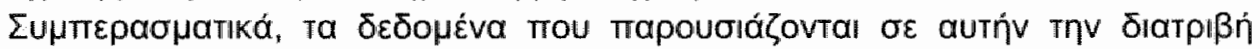

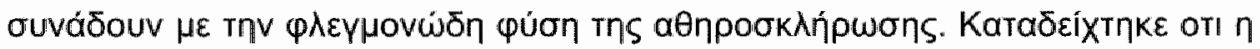

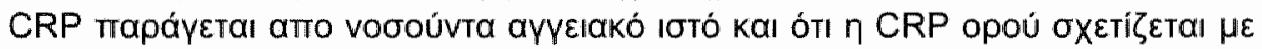

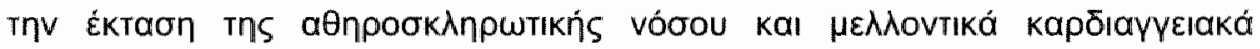

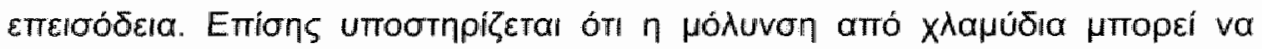

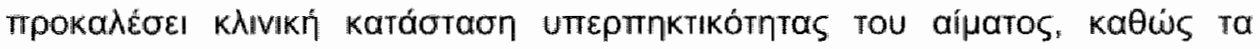

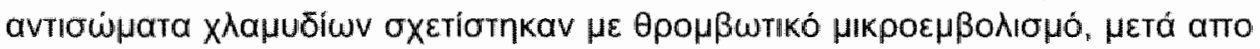

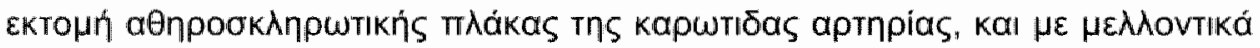

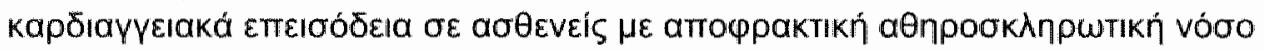

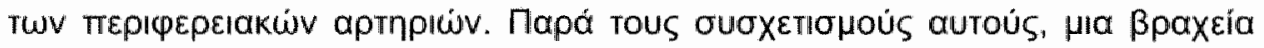

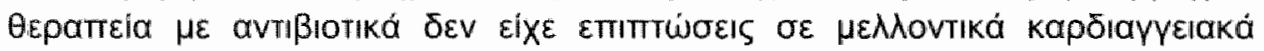

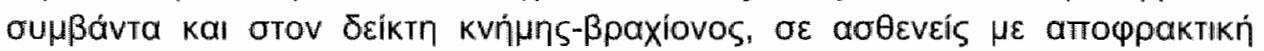

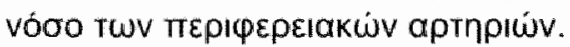


Acknowledgements 


\section{Acknowledgements}

One may suggest that since Greece won the European Football Championship and the Eurovision Song contest in one year, it should not be too difficult for a Greek like me to earn a $\mathrm{PhD}$. Indeed, after a long struggle I have finally been able to complete my thesis. Marvelous as this adventure may have been, it would not have been possible without the help of many.

I would have nothing to say or write without the inspiring co-operation of the hundreds of patients who subjected themselves to my tedious enquiries. While they gave me the chance to satisfy my curiosity and further my career, they gained nothing than my gratitude and this simple word of thanks.

Professor Kitslaar, among the medical students you had earned the reputation of being very demanding. During the last 6 years you evolved from an authoritarian teacher to an inspirational mentor, always there to tame my youthful enthusiasm and keeping me on the right track. Your methodological approach put structure into my chaotic thinking, and your critique helped me formulate hypotheses more accurately.

Professor Bruggeman, from the first day of my appointment you tried to make me feel at ease and, indeed, soon I found my place in your lab. The weekly progress meetings and journal discussions formed an important guidance and helped me keep faith in the completion of my work, even though occasionally it seemed like a lost case to me. Together with Professor Kitslaar you created the conditions that enabled me to complete my PhD thesis. I cannot thank you enough for all your support.

Dr Stassen, our best brainstorm sessions were followed by the most hideous hangovers. I wonder how many brilliant ideas have been lost in the bottom of countless beer glasses. I am sure that if we would write down half of the ideas generated in alcohol I could have written 3 PhD theses in half the time. I am certainly looking forward to many more 'scientific meetings' in the future.

Dr Kurvers played a key role in the design of the initial research project. It's a shame that we didn't have the chance to collaborate more closely during the course of my research appointment. I know it would have increased my scientific output significantly.

Dr Welten, I guess that neither you nor I had realised fully the implications of your exclamation: "Doc you go to England" after you had arranged a clinical attachment for me at Leicester Royal Infirmary under supervision of Sir Professor Bell. My time in England inspired me to go into vascular research. On my return to Maastricht, you played an important role in the realisation of our clinical studies, which would not have been possible without the patients recruited from your clinic.

The weekly visits to Sittard were a welcome change from the frenzy of academia. Dr Van den Akker, your down to earth, no nonsense approach of the 
vascular patient was a refreshing reminder that $\|$ shouldn't take my scientific work too serious. After all "a salvaged limb is worth a thousand publications.

Dr Jan Tordoir and Dr Geert Willem Schurink provided me not only with many patients for the studies but also with invaluable advice. The aneurysm work described in chapter 3 would not have been possible without the inspiring involvement and sharp reasoning of Geert Willem. I am looking forward to continue working with you on this matter in the future.

Professor Mess, it's amazing how much can be learnt from little 'bleeps'. Every time I thought I understood the significance of micro-embolic signals you showed me how limited my understanding was. Our discussions about TCD monitoring, micro-embolic signals and carotid plaques were most inspiring and I hope we can continue them after completion of my $\mathrm{PhD}$.

Dr Morré, we joined forces quite late in the course of my studies. We in Maastricht, had the patient material and you, in Amsterdam, had the SNP's and thousands of ideas. Our meetings used to be very fruitful and -1 have to confess- sometimes dazzling. Occasionally I would get lost in the plethora of hypotheses, ideas for new studies etc. I hope we will continue our collaboration in the future.

Professor van Diejien-Visser, thank you for your faith in my ideas and the hundreds of high sensitive CRP measurements carried out in your laboratory. 1 look forward to working with you on aortic proteomics.

I spent countless hours in the microbiology lab. In contrast to my expectations, I grew to like the lab-work, not in the least due to the people there. In Gert I found a surrogate mother. She always knew where I misplaced my samples and made sure I cleaned up my mess after a days work. Without her help, I probably would still be staining countless plaques. The molecular work would have not been possible without the commitment and hard work of Selma. It is said that shared happiness is double happiness and shared pain is half the pain. I have to thank the other PhD students (Inge, Manuela, Tania and Rajaa) for doubling the fun and reducing the misery all these years.

Although it never felt like it at the time, it actually was a privilege to work with the many keen students. To have the ability to motivate young minds to enter the world of research and to be inspired by them was an amazing experience. I would like to thank, Marianne, Remy, Roger, Tim and Steef for their contribution to my work. Eric, I'm sorry that you didn't join the club earlier. Good luck with your surgical training and $\|$ hope you will find time to continue your scientific efforts. Rick and Linda, thank you for all the work and the long days in the lab. It was a privilege to supervise you in your first steps in science. I am sure you both have a brilliant career ahead of you. I am happy to be able to pass the 'torch' on to Femke. I wish you the best of luck.

Keeping track of 509 patients would not be possible without the relentless work of the outpatient clinic nurses of Maastricht University Hospital, Atrium Medical 
Centre Heerlen and Maasland Hospital Sittard. It's amazing how much can be achieved on one strawberry pie. Many thanks are due to the vascular technicians of Maastricht University Hospital, Atrium Medical Centre Heerien and Maasland Hospital Sittard, for countless ankle-brachial pressure measurements and duplex ultrasound scans.

I would like to thank the attending surgeons of the department of Surgery of Maastricht University Hospital for letting me loose on their patients. Many thanks also to my fellow residents, for supporting me in my initial endeavours as a clinician.

Ruben, we practically lived together in that bloody room in the hospital. I am ashamed to admit that often we spent more time with each other than with our partners. I would like to especially thank you and Diana for making these 4 years as inspiring and memorable as they were.

I am proud that my brother, Damian, will support me during the defence of my thesis. I cannot thank my family enough for their unconditional support and

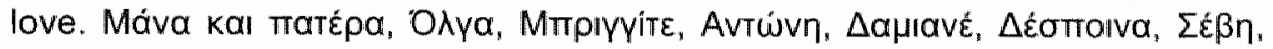

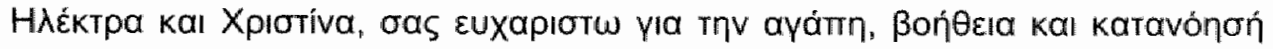
oas. I will always be grateful to my parents for encouraging me to pursue my dreams and granting me the freedom to do so on my own terms.

Saiqa, you probably will not believe this but I really finished that bloodly $\mathrm{PhD}$ finally. Thank you for listening to my boring presentations, correcting my dull manuscripts, spending time with me in the lab, and above all never losing faith in me. "In six years the young adventurer had travelled half the world and had seen some of the amazing wonders of nature and man. He had tried new tastes and talked to many wise men. But only now, back at home, he realised that the ultimate wisdom lay in the depths of the eyes of the woman who, during the entire journey, accompanied him in his thoughts'.

Tpúpwras 
200 
List of publications 


\section{List of publications}

\section{Original Papers}

Peeters MCE, Hekking JWM, Vainas T, Drukker J, van Straaten HWM. Spatiotemporal curvature pattern of the caudal body axis for non-mutant and curly tail mouse embryos during the period of caudal neural tube closure. Anatomy and Embryology 1997;195:259-66.

Peeters MCE, Vainas T, Pietersen AM, Hekking JWM, van Straaten HWM. The curvature of embryos as measured at each somite level. Eur J Morphol $1997 ; 35: 42$.

Hayes PD, Vainas T, Hartley S, Thompson MM, London NJM, Bell PRF, Naylor AR. The Pruitt-Inahara shunt maintains mean middle cerebral artery velocities within $10 \%$ of preoperative values during carotid endarterectomy. I Vasc Surg 2000;32(2):299-306.

Vainas T, Kurvers HAJM, Lahaije MJE, Kitslaar PJEHM. Van Atherosclerose tot Hart- en Vaatziekte: Spelen Infecties hierin een rol? VNIVD Vakblad voor Vaatdiagnostiek. 2000;13(4):28-33.

Vainas $T$, Kurvers HAJM, Mess $W H$, de Graaf $R$, Ezzahiri $R$, Tordoir JHM, Schurink GWH, Bruggeman CA, Kitslaar PJEHM. Chlamydia pneumoniae $(\mathrm{Cpn})$ serology is associated with thrombosis-related but not with plaquerelated micro-embolization during carotid endarterectomy. Stroke 2002; 33:1249-54.

Vainas T, de Graaf R, Stassen FRM, Kurvers HAJM, Grauls GELM, Kitslaar PJEHM, Bruggeman CA. Chlamydia pneumoniae serology: comparing a commercial enzyme immunoassay and microimmunofluorescence test in patients with cardiovascular disease. APMIS 2003;111(2):363-9.

Vainas T, Lubbers T, Stassen FRM, Herngreen SB, van Dieijen-Visser MP, Bruggeman CA, Kitslaar PJEHM, Schurink GWH. Serum C-Reactive Protein level is associated with abdominal aortic aneurysm size and may be produced by aneurysmal tissue. Circulation. 2003:107:1103-5.

De Graaf R, Dammers R, Vainas T, Hoeks AP, Tordoir JH. Detection of cellcycle regulators in failed arteriovenous fistulas for haemodialysis. Nephrol Dial Transplant. Apr 2003;18(4):814-8. 
Hulsewe KWE, van Acker BAC, Hameeteman W, van der Hulst RRWJ, Vainas T, Arends JW, van Kreel BK, von Meyenfeldt MF, Soeters PB. Does glutamineenriched parenteral nutrition really affect intestinal morphology and gut permeability? Cin Nutr 2004:23:1217-25.

Vainas $T_{\text {}}$ Stassen FRM, Schurink GWH, Tordoir JHM, , Welten RJThJ, van den Akker LHJM, Kurvers HAJM, Bruggeman CA, Kitslaar PJEHM. Secondary Prevention of atherosclerosis through Chlamydia pneumoniae eradication (SPACE triall) in patients with peripheral arterial disease. A randomised clinical trial. Eur J Vasc Endovasc Surg $2005 ; 29(4): 403-11$.

Van Laake L, Vainas T, Dammers R, Kitslaar PJEHM, Hoeks APG, Schurink GWH. Systemic dilation diathesis in patients with abdominal aortic aneurysms: a role for matrix metalloproteinase-9? Eur $\mathcal{\prime}$ Vasc Endowasc Surg $2005 ; 29(4)$ : $371-377$.

Vainas T, Kitslaar PJEHM. Beinvloeding van atherosclerose door antibiotica: Resultaten van een gerandomiseerd onderzoek bij patiënten met perifeer arterieel vaatlijden. Hartbulletin 2005;36(5):131-3.

Vainas T, Stassen FRM, de Graaf R, Twiss ELL, Welten RJThd, van den Akker LHJM, van Dieijen-Visser M, Bruggeman CA, Kitslaar PJEHM. C-reactive protein in peripheral arterial disease: relation to severity of the disease and to future cardiovascular events. J Vasc Surg 2005;42:243-51.

Vainas T, Stassen FRM, Schurink GWH, Tordoir JHM, Welten RJThJ, van den Akker LHJM, Kurvers HAJM, Bruggeman CA, Kitslaar PJEHM. Reply to: Effect of Macrolides on Peripheral Arterial Disease Depends on Patient Selection and Adequate Treatment. P.A. Krayenbuehl, P. Wiesli, T. Meier, G Schulthess. Eur $J$ Vasc Endovasc Surg $2005 ; 30(3): 337$.

Vainas T, Sayed S. Antibiotics in acute and chronic coronary syndromes. K/mik und Forschung. 2005:11(1):4-7.

Vainas T, Stassen FRM, Kurvers HA, Grauls GE, Bruggeman CA, Kitslaar PJ. Chlamydia pneumoniae in atherosclerotic disease: association between serum antibody titers and presence of antigens/DNA in vascular tissue. Submitted.

Vainas T, Stassen FRM, de Graaf $R$, Bruggeman CA, Kitslaar PJEH. Presence of inflammatory cells in veins implanted as bypass grafts is associated with subsequent graft failure. Submitted. 
Vainas T, Stassen FRM, Bruggeman CA, Kitslaar PJEHM, Pena AS, Morre SA. Synergistic effect of Toll like receptor 4- and CD-14 polymorphisms on total atherosclerosis burden in patients with peripheral arterial disease. Submitted.

Veurstaek JD, Vainas $T$, Thissen CA, Wuite $J$, van der Kley JA, Nelemans $P$, Neumann MH, Steijlen P, Veraart JC. State-of-the art treatment of chronic leg ulcers: Assessing the role of Vacuum Assisted Closure (V.A.C. $)$ in wound healing. Submitted.

Rademakers LMF, Vainas T, Van Helden SH, Van Zutphen SWAM, Verbruggen J, Brink PRG and. Pressure ulcers and prolonged length of hospital stay in hip fracture patients due to delay in operation. Submitted.

\section{Book Chapters}

Vainas $T$, Kurvers HAJM, Mess $W H$, de Graaf $R$, Ezzahiri $R$, Tordoir JHM, Schurink GWH, Bruggeman CA, Kitslaar PJEHM. Chlamydia pneumoniae in carotid artery disease: association with plaque instability or hypercoagulability?, in Chlamydial infections. Proceedings of the 10th international symposium on human chlamydial infections, J. Schachter, et al., Editors. 2002, International Chlamydia Symposium: San Francisco. p. 337-40.

Vainas T, Stassen FRM, Bruggeman CA, Schurink GWH, Kitslaar PJEHM. Creactive protein, inflammation and abdominall aortic aneurysms, in Progress Report Cardiovascular Research Institute Maastricht 2003. van der Zander R, Editor. 2003. CARIM: Maastricht. p. 100-4. 
Curriculum Vitae 


\section{Curriculum Vitae}

The author was born on October 26, 1969 in Heinsberg. Germany, into a family of Greek emigrants. In 1980 he followed his family back to Greece where he graduated from the $1^{\text {st }}$ Lyceum of Thessaloniki in 1988. After a period of soulsearching, the author settled in Maastricht in 1992 where he studied at the medical faculty of Maastricht University (formerly known as Rijksuniversiteit Limburg) from September 1992 until November 1998. During his sludies, the author served as student research assistant for the departments of Anatomy and Embryology (1995, Dr M Peeters \& Dr H van Straaten), Obstetrics and Gynaecology (1996-97, Dr H Keunen \& Dr T Hasaart) and General Surgery (1997-98, Dr K Hulsewe \& Prof Soeters). In 1998 he followed an elective clinical and research attachment for 3 months at the department of vascular surgery, Leicester Royal Infirmary, Leicester, UK (Sir Prof PE Bell \& Prof AR Naylor). After graduation the author accepted a position as PhD-student at the department of Surgery, Maastricht University Hospital and Cardiovascular Research Institute of Maastricht. During that period the work described in this thesis was performed. In May 2003 he started his training in General Surgery at Maastricht University Hospital (Supervisor Prof M.J. Jacobs and later Prof J.W. Greve) which will be completed at the department of Surgery of Catharina Ziekenhuis Eindhoven (Supervisor Dr G. Nieuwenhuizen). Together with Dr Schurink (Dept of Surgery, Maastricht University Hospital) he has been awarded a CARIM/Maastricht University grant in 2005 which will enable him to continue his scientific endeavors. The author has lost his heart to and found his inspiration in Miss Saiqa Sayed. 
Printing of this thesis and the activities related to the defense of the PhD has financially been supported by:

AstraZeneca BV, Nycomed Nederland BV, SanofiSynthelabo BV, Johnson \& Johnson Medical BV, B.Braun Medical BV, Wyeth Pharmaceuticals BV, Bristol-Myers Squibb BV, Cook Nederland BV, Pie Medical Equipment BV. 